Prepared in cooperation with the Fort Irwin National Training Center

\title{
Geohydrology, Geochemistry, and Groundwater Simulation (1992-2011) and Analysis of Potential Water-Supply Management Options, 2010-60, of the Langford Basin, California
}

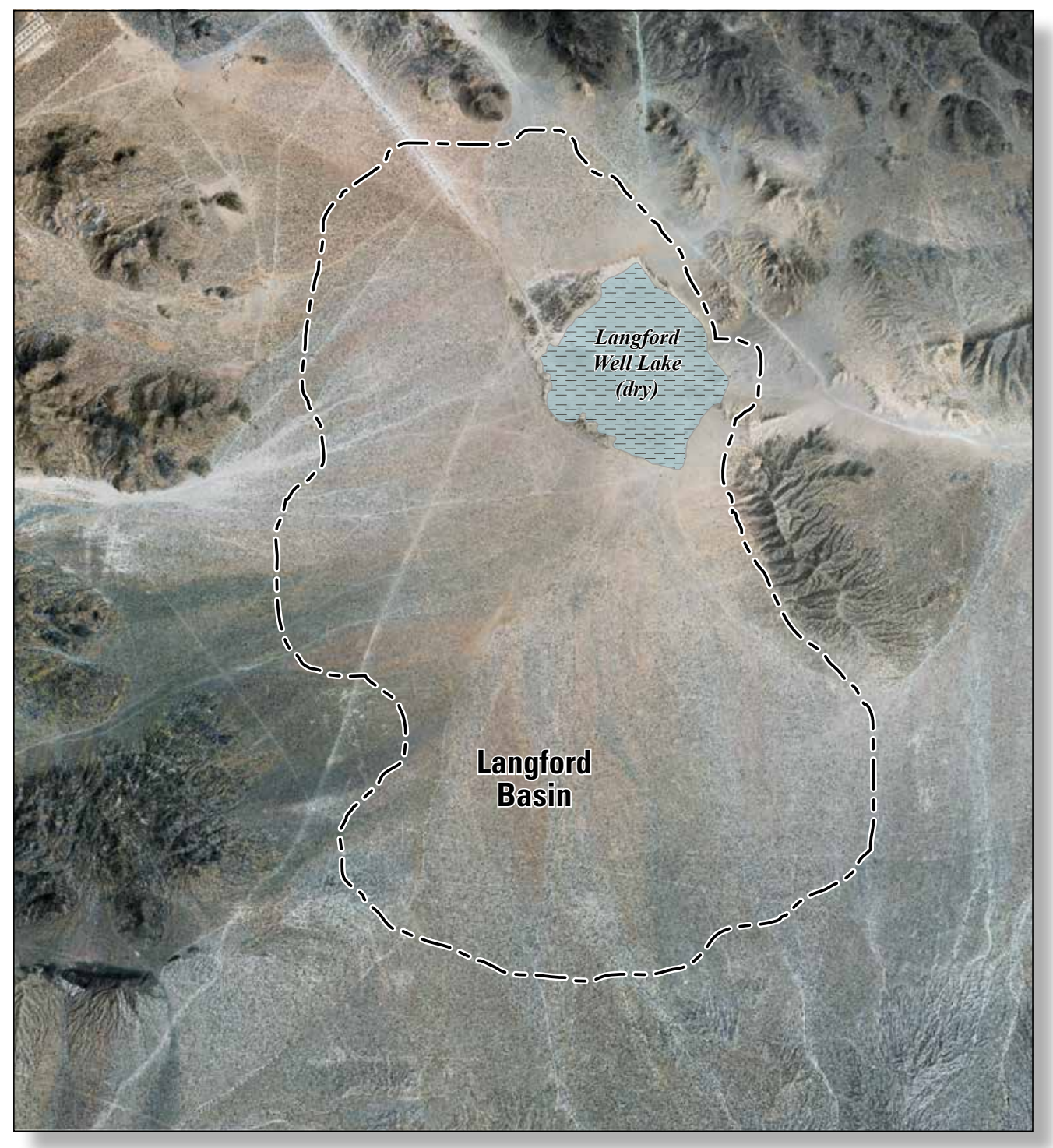

Scientific Investigations Report 2013-5101 
Cover photograph. Aerial view of the Langford groundwater basin. Photograph from Fort Irwin National Training Center, 2007. 


\section{Geohydrology, Geochemistry, and Groundwater Simulation (1992-2011) and Analysis of Potential Water-Supply Management Options, 2010-60, of the Langford Basin, California}

By Lois M. Voronin, Jill N. Densmore, Peter Martin, Charles F. Brush, Carl S. Carlson, and David M. Miller

Prepared in cooperation with the Fort Irwin National Training Center

Scientific Investigations Report 2013-5101 


\title{
U.S. Department of the Interior SALLY JEWELL, Secretary
}

\section{U.S. Geological Survey \\ Suzette M. Kimball, Acting Director}

\author{
U.S. Geological Survey, Reston, Virginia: 2013
}

For more information on the USGS - the Federal source for science about the Earth, its natural and living resources, natural hazards, and the environment, visit http://www.usgs.gov or call 1-888-ASK-USGS.

For an overview of USGS information products, including maps, imagery, and publications, visit http://Www.usgs.gov/pubprod.

To order this and other USGS information products, visit http://store.usgs.gov.

Any use of trade, firm, or product names is for descriptive purposes only and does not imply endorsement by the U.S. Government.

Although this information product, for the most part, is in the public domain, it also may contain copyrighted materials as noted in the text. Permission to reproduce copyrighted items must be secured from the copyright owner.

Suggested citation:

Voronin, L.M., Densmore, J.N., Martin, Peter, Brush, C.F., Carlson, C.S., and Miller, D.M., 2013, Geohydrology, geochemistry, and groundwater simulation (1992-2011) and analysis of potential water-supply management options, 2010-60, of the Langford Basin, California: U.S. Geological Survey Scientific Investigations Report 2013-5101, 86 p. 


\section{Contents}

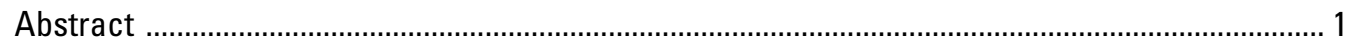

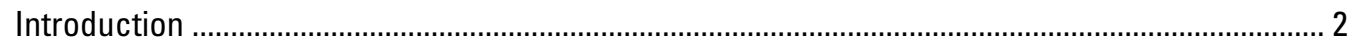

Purpose and Scope ................................................................................................................... 2

Location and Description of Study Area ............................................................................. 2

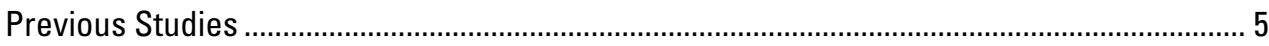

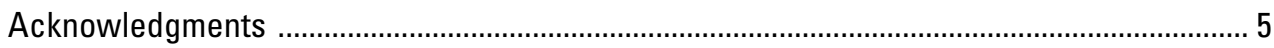

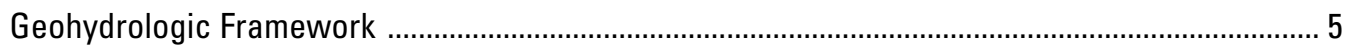

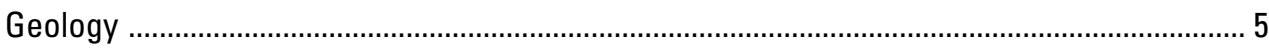

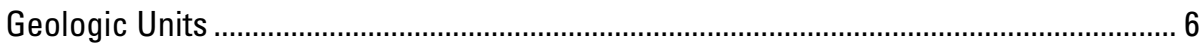

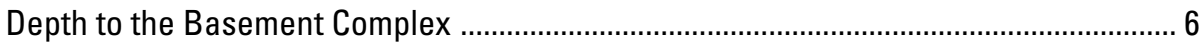

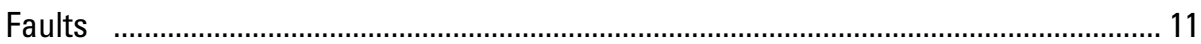

Groundwater Hydrology .................................................................................................. 11

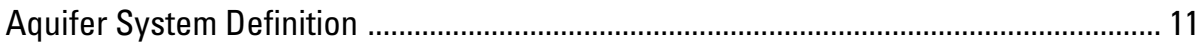

Recharge and Discharge .............................................................................................. 12

Groundwater Withdrawals and Water Use ................................................................. 13

Groundwater Levels and Flow ..................................................................................... 13

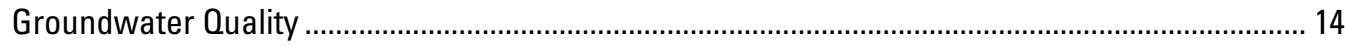

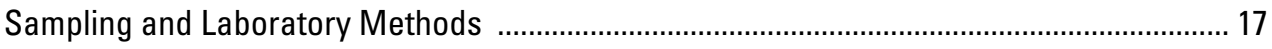

General Water-Quality Characteristics ................................................................................. 17

Chemical Character of Groundwater ............................................................................... 17

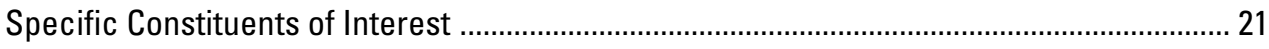

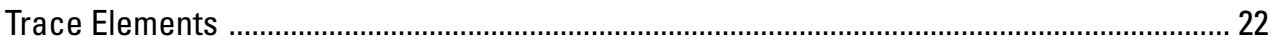

Source and Age of Groundwater ......................................................................................... 23

Stable Isotopes of Oxygen and Hydrogen .................................................................... 23

Tritium and Carbon-14 ................................................................................................ 23

Simulation of Groundwater Flow ........................................................................................... 26

Model Discretization ........................................................................................................ 26

Model Boundaries ................................................................................................................. 27

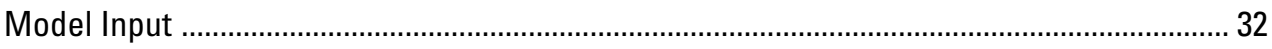

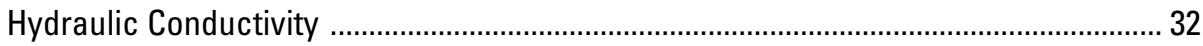

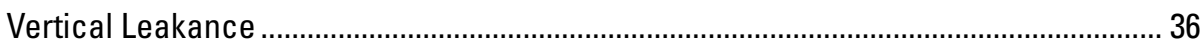

Specific Yield and Specific Storage ................................................................................ 36

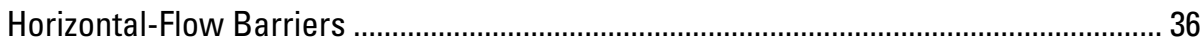

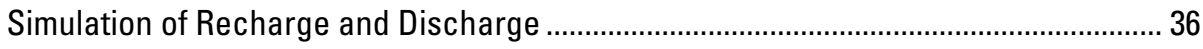

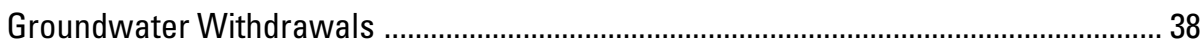

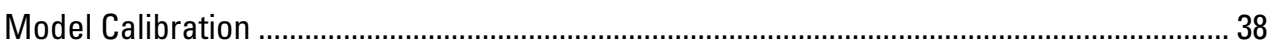

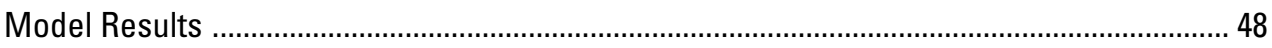

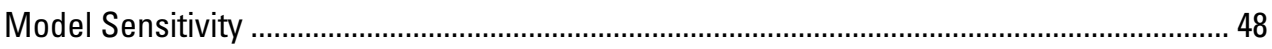

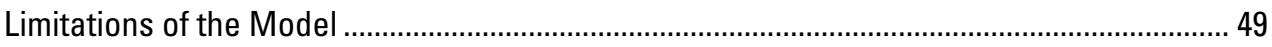

Simulated Effects of Future Groundwater Withdrawals ..................................................... 51

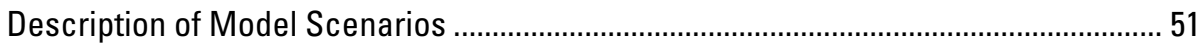

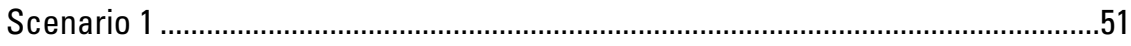

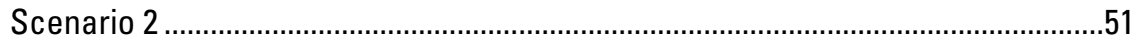




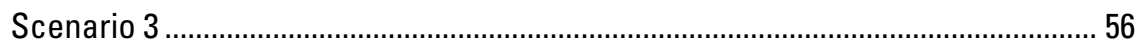

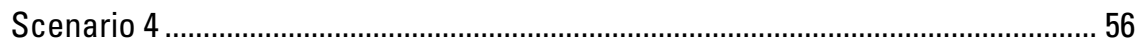

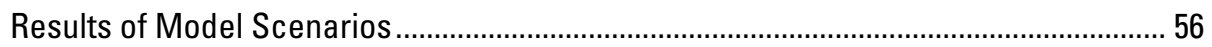

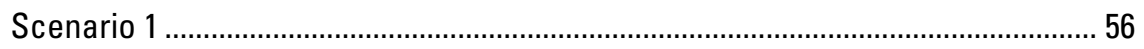

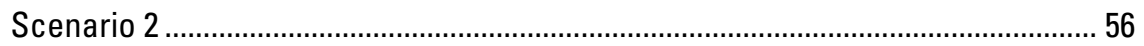

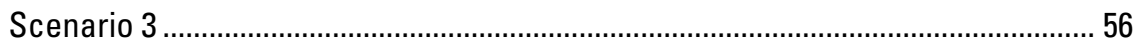

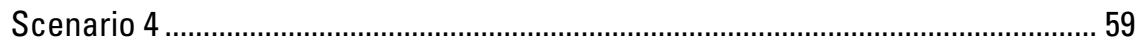

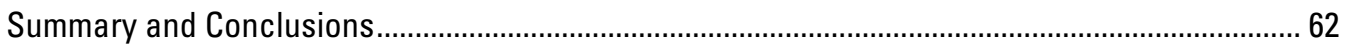

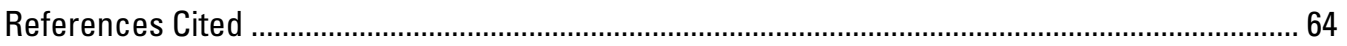

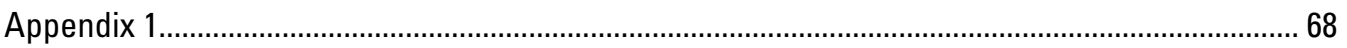

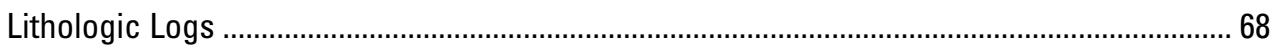

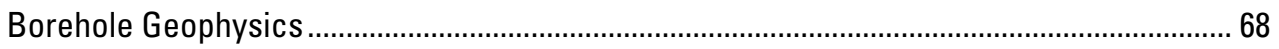

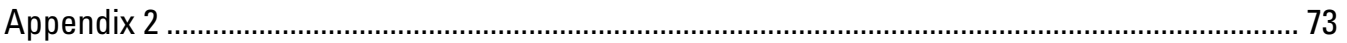

\section{Figures}

1. Map showing location of study area, Fort Irwin National Training Center, California ......... 3

2. Map showing generalized surficial geology, major faults, location of groundwater monitoring sites and production wells, and geologic section lines in Langford Basin, Fort Irwin National Training Center, California 4

3. Generalized geologic sections $A, A-A^{\prime} ; B, B-B^{\prime}$; and $C, C-C^{\prime}$ across Langford Basin, Fort Irwin National Training Center, California

4. Map showing altitude of the basement complex in Langford Basin, Fort Irwin National Training Center, California, based on gravity measurements 10

5. Graph showing $A$, Groundwater withdrawal, and $B$, water-level fluctuations in selected wells in Langford Basin, Fort Irwin National Training Center, California

6. Graph showing monthly distribution of groundwater withdrawals, January 1993December 2010, Langford Basin, Fort Irwin National Training Center, California

7. Maps showing groundwater-level contours for $A$, predevelopment (1980-88); $B, 1995 ; C, 2000 ; D, 2005$; and $E, 2010$ in Langford Basin, Fort Irwin National Training Center, California

8. Map showing location of stiff diagrams, and concentrations of dissolved solids, sulfate, nitrate, and fluoride in groundwater from selected wells in Langford Basin, Fort Irwin National Training Center, California

9. Trilinear diagrams of groundwater from selected wells in $A$, the northern part; $B$, the central part; and $C$, the southern part of Langford Basin, Fort Irwin National Training Center, California

10. Plot showing relation between concentrations of chloride and sulfate in groundwater samples from wells in Langford Basin, Fort Irwin National Training Center, California

11. Plot showing stable-isotope concentrations in groundwater from selected wells in Langford Basin, Fort Irwin National Training Center, California

12. Map showing tritium and carbon-14 activities in groundwater from selected wells in Langford Basin, Fort Irwin National Training Center, California

13. Map showing local model grid of the Langford Basin and the regional mode grid of the Fort Irwin National Training Center, California 
14. Map showing finite-difference grid and boundary locations, Langford Basin, Fort Irwin National Training Center, California ....

15. Cross-sectional view $A, A-A^{\prime} ; B, B-B^{\prime} ;$ and $C, C-C^{\prime}$ of model layers and horizontal hydraulic conductivities in the Langford Basin, Fort Irwin National Training Center, California

16. Map showing areal distribution of hydraulic parameter zones, horizontal hydraulic conductivity, specific yield (layer 1), specific storage, vertical anisotropy, and horizontal-flow barriers used in the model for $A$, model layer $1 ; B$, model layer 2 ; and $C$, model layer 3 for the calibrated transient groundwater-flow model, Langford Basin, Fort Irwin National Training Center, California

17. Map showing recharge distribution zones and recharge rates for the calibrated transient groundwater-flow model, Langford Basin, Fort Irwin National Training Center, California

18. Map showing simulated water-table surface and measured water levels for the upper aquifer, Langford Basin, Fort Irwin National Training Center, California. $A$, Predevelopment; $B$, February 1995; $C$, March 2005; D, October 2010; and E, Simulated drawdown from April 1992 to October 2010

19. Hydrographs of simulated and measured water levels in 12 wells from predevelopment (1980-88) to January 2011, Langford Basin, Fort Irwin National Training Center, California

20. Graph showing measured and simulated equivalent water levels, with 1:1 correlation line, for transient conditions, Langford Basin, Fort Irwin National Training Center, California

21. Graph showing composite scaled sensitivity values, Langford Basin, Fort Irwin National Training Center, California.

22. Graph showing average 2001 to 2010 monthly groundwater withdrawal distribution for wells in Bicycle, Irwin, and Langford Basins providing water to Fort Irwin National Training Center, California

23. Map showing simulated drawdown from 0 ctober 2010 conditions to 0 ctober 2060 conditions for $A$, scenario $1 ; B$, scenario 2 ; $C$, scenario 3 ; and $D$, scenario 4 , Langford Basin, Fort Irwin National Training Center, California

24. Graphs showing simulated hydrographs from scenario 1, Langford Basin, Fort Irwin National Training Center, California

25. Graphs showing simulated hydrographs from scenario 2, Langford Basin, Fort Irwin National Training Center, California

26. Graphs showing simulated hydrographs from scenario 3, Langford Basin, Fort Irwin National Training Center, California

27. Graphs showing simulated hydrographs from scenario 4, Langford Basin, Fort Irwin National Training Center, California

\section{Appendix figures}

A1-1. Geophysical logs, well-construction diagram, and stratigraphic column for the borehole of monitoring site drilled in Langford Basin at Fort Irwin National

Training Center, California: LL1 (13N/3E-26K2-4)

A1-2. Geophysical logs, well-construction diagram, and stratigraphic column for borehole of monitoring site drilled in Langford Basin at Fort Irwin National Training Center, California: LL2 (13N/3E-35J1-3)

A1-3. Geophysical logs, well-construction diagram, and stratigraphic column for borehole of monitoring site drilled in Langford Basin at Fort Irwin National Training Center, California: LL3 (13N/3E-24N1) 
A1-4. Geophysical logs, well-construction diagram, and stratigraphic column for borehole of monitoring site drilled in Langford Basin at Fort Irwin National Training Center,

California: LW1 (13N/3E-14K1)

A1-5. Geophysical logs, well-construction diagram, and stratigraphic column for borehole of monitoring site drilled in Langford Basin at Fort Irwin National Training Center, California: LLO4B (12N/3E-1M4 and 5) and LL04 (12N/3E-1M1-3)

\section{Tables}

1. Well-construction data for selected wells in Langford Basin, Fort Irwin National Training Center, California

2. Results of aquifer tests conducted in Langford Basin, Fort Irwin National Training Center, California

3. Summary of annual groundwater withdrawals, in acre-feet per year, from three wells in Langford Basin, Fort Irwin National Training Center, California, April 1992December 2010

4. Calibrated parameter values for the calibrated groundwater-flow model, Langford Basin, Fort Irwin National Training Center, California

5. Simulated predevelopment and annual water budget, 1992-2010, Langford Basin, Fort Irwin National Training Center, California

6. Simulated and 1993-2011 measured water levels and root mean square error for 12 wells, Langford Basin, Fort Irwin National Training Center, California

7. Calibrated parameter values used in the calibrated model, Langford Basin, Fort Irwin National Training Center, California

8. Summary of four model scenarios in the Langford Basin, Fort Irwin National Training Center, California

Appendix 2. Water-quality data for selected wells and a spring in Langford Basin, Fort Irwin National Training Center, California, 1955-2011 


\section{Conversion Factors, Datums, and Water-Quality Units}

Inch/Pound to SI

\begin{tabular}{|c|c|c|}
\hline Multiply & By & To obtain \\
\hline \multicolumn{3}{|c|}{ Length } \\
\hline inch (in.) & 2.54 & centimeter $(\mathrm{cm})$ \\
\hline foot $(\mathrm{ft})$ & 0.3048 & meter $(\mathrm{m})$ \\
\hline mile (mi) & 1.609 & kilometer $(\mathrm{km})$ \\
\hline \multicolumn{3}{|c|}{ Area } \\
\hline square mile $\left(\mathrm{mi}^{2}\right)$ & 2.590 & square kilometer $\left(\mathrm{km}^{2}\right)$ \\
\hline \multicolumn{3}{|c|}{ Volume } \\
\hline gallon (gal) & 3,785 & milliliter $(\mathrm{mL})$ \\
\hline acre-foot (acre-ft) & 0.001233 & cubic hectometer $\left(\mathrm{hm}^{3}\right)$ \\
\hline \multicolumn{3}{|c|}{ Flow rate } \\
\hline foot per day (ft/d) & 0.3048 & meter per day $(\mathrm{m} / \mathrm{d})$ \\
\hline acre-foot per year (acre-ft/yr) & 0.001233 & cubic hectometer per year $\left(\mathrm{hm}^{3} / \mathrm{yr}\right)$ \\
\hline \multicolumn{3}{|c|}{ Specific capacity } \\
\hline $\begin{array}{l}\text { gallon per minute per foot } \\
[(\mathrm{gal} / \mathrm{min}) / \mathrm{ft})]\end{array}$ & 0.2070 & liter per second per meter $[(\mathrm{L} / \mathrm{s}) / \mathrm{m}]$ \\
\hline \multicolumn{3}{|c|}{ Transmissivity* $^{*}$} \\
\hline foot squared per day $\left(\mathrm{ft}^{2} / \mathrm{d}\right)$ & 0.09290 & meter squared per day $\left(\mathrm{m}^{2} / \mathrm{d}\right)$ \\
\hline
\end{tabular}

Temperature in degrees Celsius $\left({ }^{\circ} \mathrm{C}\right)$ may be converted to degrees Fahrenheit $\left({ }^{\circ} \mathrm{F}\right)$ as follows:

${ }^{\circ} \mathrm{F}=\left(1.8 x^{\circ} \mathrm{C}\right)+32$

Temperature in degrees Fahrenheit $\left({ }^{\circ} \mathrm{F}\right)$ may be converted to degrees Celsius $\left({ }^{\circ} \mathrm{C}\right)$ as follows:

${ }^{\circ} \mathrm{C}=\left({ }^{\circ} \mathrm{F}-32\right) / 1.8$

Vertical coordinate information is referenced to the North American Vertical Datum of 1988 (NAVD 88).

Altitude, as used in this report, refers to distance above the vertical datum.

Specific conductance is given in microsiemens per centimeter at 25 degrees Celsius $\left(\mu \mathrm{S} / \mathrm{cm}\right.$ at $\left.25^{\circ} \mathrm{C}\right)$.

Concentrations of chemical constituents in water are given either in milligrams per liter (mg/L) or micrograms per liter ( $\mu \mathrm{g} / \mathrm{L})$.

Concentrations of radioactive isotopes are given in either picocuries per liter (pCi/L) or tritium units (TU).

Concentrations of stable isotopes are given in units of per mil (per thousand). 


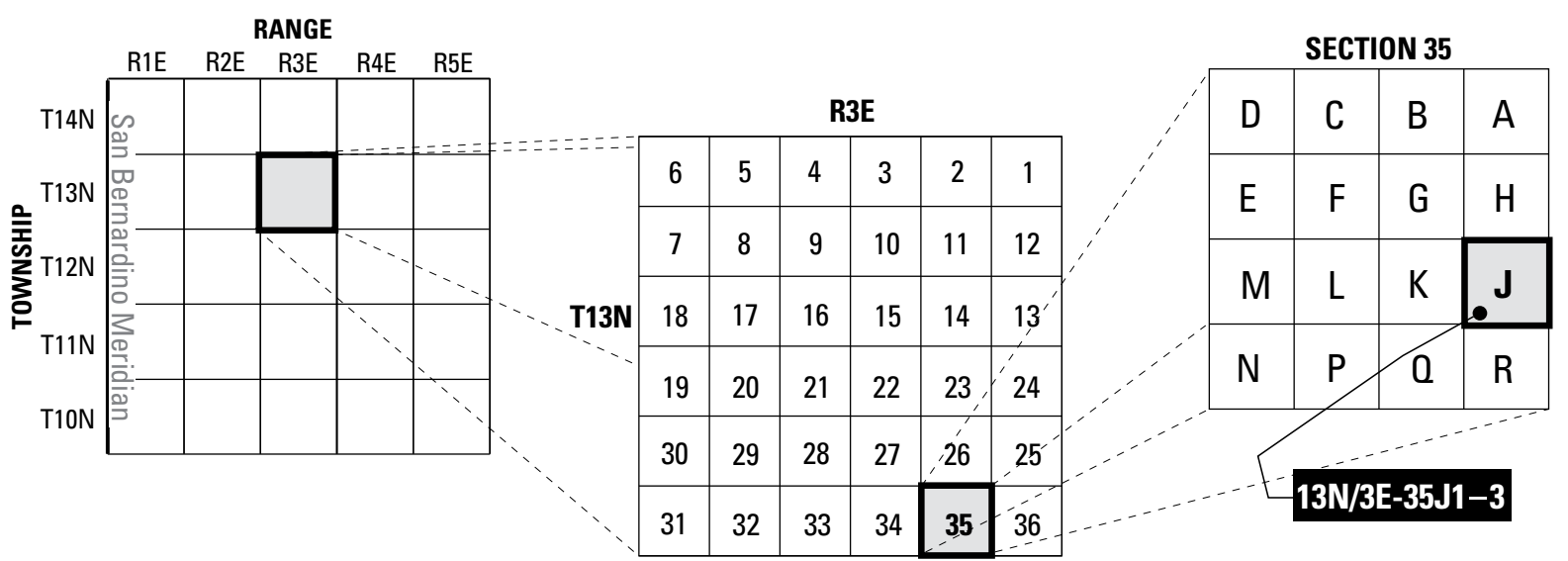

Well-numbering diagram (Note: maps in this report use abbreviated well numbers such as "35J1".) 


\section{Abbreviations}

$\begin{array}{ll}\mathrm{As} & \text { arsenic } \\ { }^{14} \mathrm{C} & \text { carbon-14, stable isotope of carbon } \\ \mathrm{F} & \text { fluoride } \\ { }^{2} \mathrm{H} & \text { deuterium, stable isotope of hydrogen } \\ { }^{3} \mathrm{H} & \text { tritium, radioactive isotope of hydrogen } \\ \mathrm{HCO}_{3} & \text { bicarbonate } \\ \mathrm{Na}^{\mathrm{Na}} & \text { sodium } \\ \mathrm{NO}_{3} & \text { nitrate } \\ \mathrm{NTC} & \text { National Training Center } \\ { }^{18} \mathrm{O} & \text { oxygen-18, stable isotope of oxygen } \\ \mathrm{Per} \text { mil } & \text { parts per thousand (\%o) } \\ \mathrm{PVC} & \text { polyvinyl chloride } \\ \mathrm{RMSE} & \text { root mean squared error } \\ \mathrm{SO} & \text { sulfate } \\ \mathrm{SP} & \text { spontaneous potential } \\ \mathrm{TDS} & \text { total dissolved solids } \\ \text { USEPA } & \text { U.S. Environmental Protection Agency } \\ \text { USGS } & \text { U.S. Geological Survey } \\ \mathrm{VSMOW} & \text { Vienna Standard Mean Ocean Water } \\ \mathrm{Bc} & \text { basement complex } \\ \text { Qoa } & \text { Quaternary older alluvium } \\ \text { Op } & \text { Quaternary playa deposits } \\ \text { Oya } & \text { Quaternary younger alluvial deposits } \\ \text { Oye } & \text { Quaternary younger eolian deposits } \\ \mathrm{Tog} & \text { Tertiary older sedimentary deposits } \\ \text { Tyg } & \text { Tertiary younger sedimentary deposits }\end{array}$




\title{
Geohydrology, Geochemistry, and Groundwater Simulation (1992-2011) and Analysis of Potential Water-Supply Management Options, 2010-60, of the Langford Basin, California
}

\author{
By Lois M. Voronin, Jill N. Densmore, Peter Martin, Charles F. Brush, Carl S. Carlson, and David M. Miller
}

\section{Abstract}

Groundwater withdrawals began in 1992 from the Langford Basin within the Fort Irwin National Training Center (NTC), California. From April 1992 to December 2010, approximately 12,300 acre-feet of water (averaging about 650 acre-feet per year) has been withdrawn from the basin and transported to the adjacent Irwin Basin. Since withdrawals began, water levels in the basin have declined by as much as 40 feet, and the quality of the groundwater withdrawn from the basin has deteriorated.

The U.S. Geological Survey collected geohydrologic data from Langford Basin during 1992-2011 to determine the quantity and quality of groundwater available in the basin. Geophysical surveys, including gravity, seismic refraction, and time-domain electromagnetic induction surveys, were conducted to determine the depth and shape of the basin, to delineate depths to the Quaternary-Tertiary interface, and to map the depth to the water table and changes in water quality. Data were collected from existing wells and test holes, as well as 11 monitor wells that were installed at 5 sites as part of this study. Water-quality samples collected from wells in the basin were used to determine the groundwater chemistry within the basin and to delineate potential sources of poor-quality groundwater. Analysis of stable isotopes of oxygen and hydrogen in groundwater indicates that present-day precipitation is not a major source of recharge to the basin. Tritium and carbon-14 data indicate that most of the basin was recharged prior to 1952, and the groundwater in the basin has an apparent age of 12,500 to 30,000 years. Recharge to the basin, estimated to be less than 50 acre-feet per year, has not been sufficient to replenish the water that is being withdrawn from the basin.

A numerical groundwater-flow model was developed for the Langford Basin to better understand the aquifer system used by the Fort Irwin NTC as part of its water supply, and to provide a tool to help manage groundwater resources at the NTC. Measured groundwater-level declines since the initiation of withdrawals (1992-2011) were used to calibrate the groundwater-flow model. The simulated recharge was about 46 acre-feet per year, including approximately 6 acre-feet per year of natural recharge derived from precipitation runoff and as much as 40 acre-feet per year of underflow from the Irwin Basin. Between April 1992 and December 2010, an average of about 650 acre-feet per year of water was withdrawn from the Langford Basin. Groundwater withdrawals in excess of natural recharge resulted in a net loss of 11,670 acre-feet of groundwater storage within the basin for the simulation period.

The Fort Irwin NTC is considering various groundwatermanagement options to address the limited water resources in the Langford Basin. The calibrated Langford Basin groundwater-flow model was used to evaluate the hydrologic effects of four groundwater-withdrawal scenarios being considered by the Fort Irwin NTC over the next 50 years (January 2011 through December 2060). Continuation of the 2010 withdrawal rate in the three existing production wells will result in 70 feet of additional drawdown in the central part of the basin. Redistributing the 2010 withdrawal rate equally to the three existing wells and two proposed new wells in the northern and southern parts of the basin would result in about 10 feet less drawdown in the central part of the basin but about 100 feet of additional drawdown in the new well in the northern part of the basin and about 50 feet of additional drawdown in the new well in the southern part of the basin. Reducing the withdrawals from the three existing production wells in the central part of the basin from about 45,000 acre-feet to about 32,720 acre-feet would result in about 40 feet of additional drawdown in the central basin near the pumping wells, about 25 feet less than if withdrawals were not reduced. The combination of reducing and redistributing the cumulative withdrawals to the three existing and two proposed new wells results in about 40 feet of additional drawdown in the central and southern parts of the basin and about 70 feet in the northern part of the basin. These results show that reducing and redistributing the groundwater withdrawals would maintain the upper aquifer at greater than 50 percent of its predevelopment saturated thickness throughout the groundwater basin. The scenarios simulated for this study demonstrate how the calibrated model can be utilized to evaluate the hydrologic effects of different water-management strategies. 


\section{Introduction}

Fort Irwin National Training Center (NTC) in the Mojave Desert of California has been used as a military training facility almost continuously since August 1940. Fort Irwin NTC presently (2011) obtains its potable water supply by withdrawing groundwater from the Irwin, Bicycle, and Langford Basins (fig. 1). Groundwater withdrawals in excess of recharge have resulted in declining groundwater levels in all three basins. In addition, water-quality concerns have caused several production wells in the Irwin Basin to be abandoned or destroyed. To effectively manage the water resources and plan for future water needs at the Fort Irwin NTC, it is important to have a complete understanding of the geohydrologic and geochemical framework of the Irwin, Langford, and Bicycle Basins.

\section{Purpose and Scope}

This report describes the geohydrologic and geochemical framework of Langford Basin and describes how the resulting information was utilized to develop and calibrate a groundwater-flow model for Langford Basin that was used to evaluate the long-term availability of groundwater in the basin. In 1992, the U.S. Geological Survey (USGS) entered into an agreement with the Fort Irwin NTC to monitor and evaluate the groundwater resources of the Fort Irwin NTC. The reader is referred to Densmore (2003) and Densmore and Londquist (1997) for more information. The work presented in this report was completed under a continuation of this agreement. The objectives of the Fort Irwin NTC groundwater study were to 1) describe the geohydrologic and geochemical framework of the groundwater basins that supply water to the Fort Irwin NTC, 2) develop groundwater-flow models that will help refine the understanding of the geohydrology of these basins, and 3) use this information to evaluate the long-term availability of groundwater for the Fort Irwin NTC. Available geohydrologic and geochemical data were compiled for the Langford Basin, and new data were collected from existing wells. Additional investigative work for this study included conducting geophysical surveys (gravity and time-domain electromagnetic induction) to refine the understanding of the size and shape of the basin (Smith, 1997; Morin, 2000; and Burgess and Bedrosain, USGS, written commun., 2011). An earlier seismic refraction survey (David Berger, U.S. Geological Survey, written commun., 1996) also was used to refine the size and shape of the basin. Monitor wells were installed to provide depth-dependent geohydrologic and geochemical data.

Water-quality samples were collected to evaluate possible sources of groundwater-quality degradation. Samples were also analyzed for the stable isotopes of oxygen-18 $\left({ }^{18} \mathrm{O}\right)$ and deuterium $\left({ }^{2} \mathrm{H}\right)$ to determine the source of groundwater and for the radioactive isotopes of tritium $\left({ }^{3} \mathrm{H}\right)$ and carbon-14 $\left({ }^{14} \mathrm{C}\right)$ to evaluate the relative age of groundwater (years since the water entered the groundwater system) in the basin.
A conceptual model of the geohydrologic system was developed by using data compiled and collected for the study of the Langford Basin, including lithologic and geophysical data from available boreholes (data shown in appendix 1). The conceptual model and groundwater-level data were used to develop and calibrate a groundwater-flow model of the Langford Basin. This calibrated groundwater-flow model will provide a better understanding of the geohydrology of the basin and is a useful tool to help estimate the long-term availability of groundwater from the basin by evaluating changes in groundwater-level altitudes (or water levels) under different withdrawal scenarios. The calibrated model also was used to evaluate the effects of continued withdrawals at the historical average rate of pumping, the addition of proposed wells, and a reduction in groundwater withdrawals on the groundwaterlevel altitude in the Langford Basin.

\section{Location and Description of Study Area}

The Langford Basin is in the southern part of the Fort Irwin NTC, about 35 miles (mi) northeast of Barstow, California (fig. 1). The Langford Groundwater Basin, herein referred to as the Langford Basin in this report, lies within the Langford Drainage Basin, which captures surface runoff. Fort Irwin NTC covers an area of about 970 square miles $\left(\mathrm{mi}^{2}\right)$ in the Mojave Desert of southern California. Langford Basin is bounded to the northeast by rugged hills at the base of Tiefort Mountain, to the northwest by rugged hills that separate Langford Basin from Irwin Basin, to the southwest by Noble Dome, to the south by Alvord Mountain, and to the east by rugged hills that separate Langford Basin from West Cronise Valley (fig. 1). Faults probably control the physiography and the shape of Langford Basin (Yount and others, 1994; Morin, 2000; Miller and Yount, 2002). Based on nearby mapped faults (fig. 2), four faults likely exist in the subsurface in the Langford Basin. Langford Well Lake (dry), a playa, lies in the northeastern part of Langford Basin (fig. 2). The basin floor ranges in altitude from 2,160 feet (ft) above NAVD 88 at the playa to $2,800 \mathrm{ft}$ above NAVD 88 at the base of Alvord Mountain.

Langford Basin, typical of desert basins in the Mojave Desert, has a relatively flat floor surrounded by generally rugged hills and mountains. The basin has a surface drainage area of about $50 \mathrm{mi}^{2}$, and the floor of the basin covers about $11 \mathrm{mi}^{2}$. The basin contains no perennial streams, but several washes flow for days after large storms. Langford Basin is drained internally to the Langford Well Lake (dry) playa (fig. 2). Extensive vegetation is present on the western side of Langford Well Lake (dry) playa, indicating that water sometimes collects on the playa in this area. Ponded water has been observed on playas at Fort Irwin NTC after large storms and can exist for weeks until the water has evaporated.

The climate of Langford Basin is typical of the Mojave Desert and is characterized by low precipitation with hot summers and cool winters. No weather records are available for Langford Basin, but weather records for nearby Goldstone, 


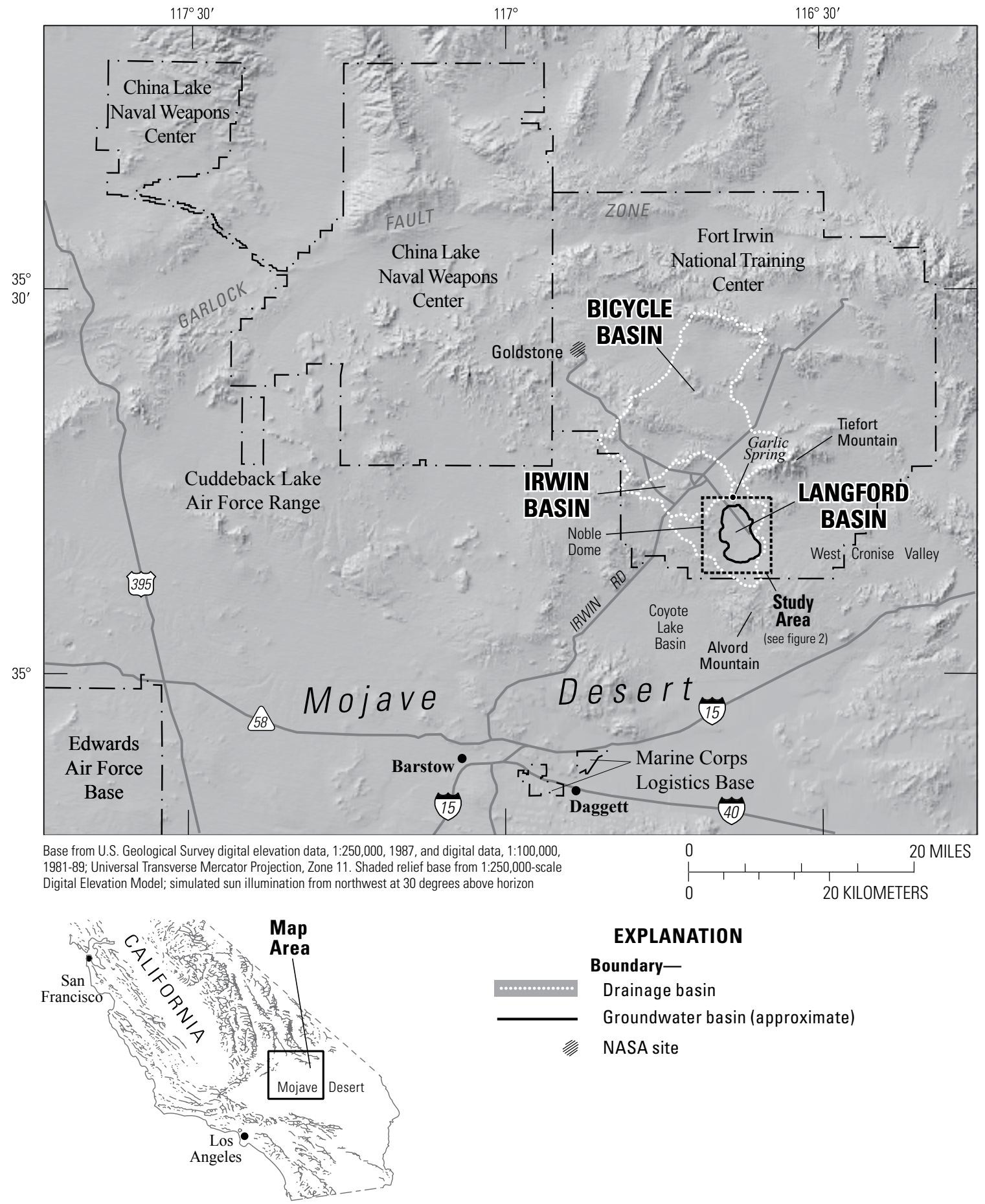

Figure 1. Location of study area, Fort Irwin National Training Center, California.

California, about $11 \mathrm{mi}$ northwest of the basin, indicate average annual precipitation is about 7 inches (in.), and ranged from 2 to 12 in. between 1950 and 2007 (National Oceanic and Atmospheric Administration, 1994, 2008). Most precipitation falls during the winter months of November through March; some additional precipitation is derived from isolated thunderstorms during the months of April through October. The average annual temperature at Barstow, California, between 1940 and 2011 was $64^{\circ} \mathrm{F}$ and ranged from 3 to $121^{\circ} \mathrm{F}$ (EarthInfo, Inc., 1995, 2000; California Irrigation Management Information System, 2011). The average annual potential evaporation in Death Valley (not shown on map), about $85 \mathrm{mi}$ north of the basin, is about $148 \mathrm{in}$. and about 76 in. at Newberry Springs, California (not shown on map), about $20 \mathrm{mi}$ to the south (David Inouye, California Department of Water Resources, written commun., 1996). 

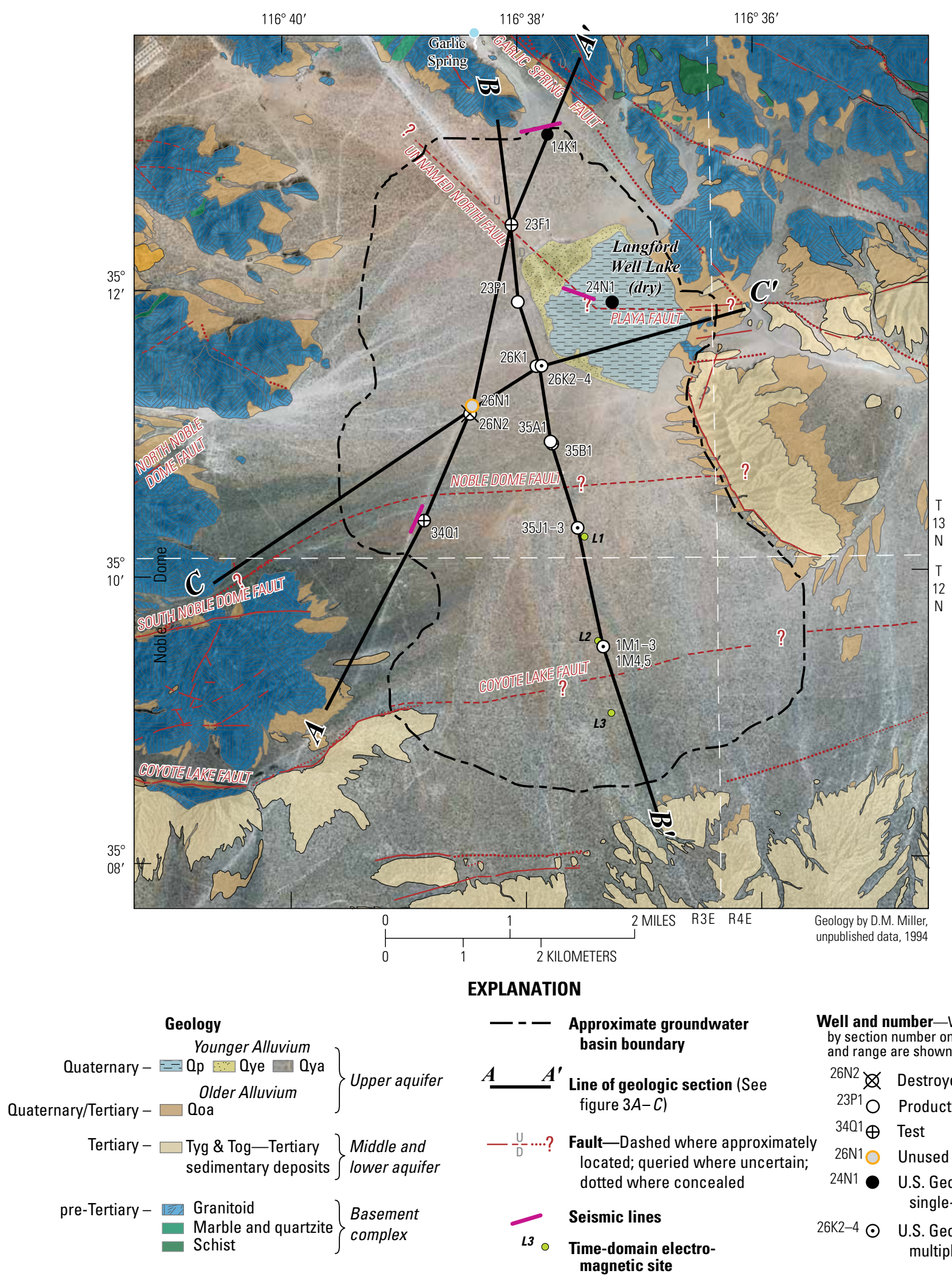
Well and number-Well identified by section number only; township and range are shown on this figure$$
{ }^{26 \mathrm{~N} 2} \not \text { Destroyed }
$$$$
{ }^{23 \mathrm{P} 1} \mathrm{O} \text { Production }
$$$$
{ }^{3401} \oplus \text { Test }
$$$$
26 \mathrm{~N} 1 \bigcirc \text { Unused production }
$$$$
\text { 24N1 U.S. Geological Survey }
$$ single-well site
26K2-4 $\odot \quad$ U.S. Geological Survey multiple-well site

Figure 2. Generalized surficial geology, major faults, location of groundwater monitoring sites and production wells, and geologic section lines in Langford Basin, Fort Irwin National Training Center, California. 


\section{Previous Studies}

Previous studies of the Langford Basin have been conducted by the USGS and by several consulting and engineering companies. Kunkel and Riley (1959) reported on a hydrogeological reconnaissance of the basin. Studies of groundwater availability were published by C.F. Hostrup and Associates (1955), James M. Montgomery and Associates (1981), and Wilson F. So and Associates (1989). Yount and others (1994) and Schermer and others (1996) published reports on the geology of the area. In conjunction with the present study, Smith (1997) and Morin (2000) conducted gravity surveys of the altitude of the top of the buried basement complex.

\section{Acknowledgments}

The authors thank the following personnel at Fort Irwin NTC: Justine Dishart, Suzanne Beacham, John Sponsler, Muhammed Bari, and Chris Woodruff for providing groundwater withdrawal data; Walt Young, Bill Anderson, and Miles Hubbard for providing access to the production wells to collect samples and measure water levels; Jennifer Swindel for assistance in coordinating field work; and the personnel at Range Control for providing informative and invaluable safety briefings.

\section{Geohydrologic Framework}

The geohydrologic framework of the Langford Basin was derived by evaluating information in previously published reports, conducting geophysical surveys, and collecting geologic and hydrologic data from existing and newly drilled wells. The local well name, State well number, and wellconstruction data for all wells used in this report are listed in table 1. These data are stored in the USGS National Water Information System (NWIS) database and can be accessed at http://waterdata.usgs.gov/ca/nwis/nwis.

\section{Geology}

The geology of Langford Basin was previously described by C.F. Hostrup and Associates (1955), Kunkel and Riley (1959), Byers (1960), James M. Montgomery and Associates (1981), Wilson F. So and Associates (1989), Yount and others (1994), and Schermer and others (1996). The geologic discussion presented in this report summarizes information from these reports and updates the geology on the basis of work completed as part of the study of the Langford Basin at the Fort Irwin NTC.

Table 1. Well-construction data for selected wells in Langford Basin, Fort Irwin National Training Center, California.

[Abbreviations: NTC, National Training Center; NAVD 88, North American Vertical Datum of 1988]

\begin{tabular}{|c|c|c|c|c|c|c|c|}
\hline $\begin{array}{c}\text { State well } \\
\text { number }\end{array}$ & $\begin{array}{l}\text { Local well } \\
\text { name }\end{array}$ & $\begin{array}{c}\text { Current NTC } \\
\text { name }^{1}\end{array}$ & $\begin{array}{c}\text { Depth } \\
\text { of well } \\
\text { (feet) }\end{array}$ & $\begin{array}{c}\text { Top of } \\
\text { open } \\
\text { interval } \\
\text { (feet) }\end{array}$ & $\begin{array}{c}\text { Bottom of } \\
\text { open } \\
\text { interval } \\
\text { (feet) }\end{array}$ & $\begin{array}{l}\text { Altitude of } \\
\text { land surface } \\
\text { (NAVD 88) } \\
\text { (feet) }\end{array}$ & $\begin{array}{c}\text { Date of } \\
\text { construction }\end{array}$ \\
\hline $12 \mathrm{~N} / 3 \mathrm{E}-1 \mathrm{M} 1$ & LL04-1 & & 970 & 950 & 970 & $2,410.00$ & $1 / 18 / 2011$ \\
\hline $12 \mathrm{~N} / 3 \mathrm{E}-1 \mathrm{M} 2$ & ${ }^{2} \mathrm{LLO} 04-2$ & & 490 & 470 & 490 & $2,410.00$ & $1 / 18 / 2011$ \\
\hline $12 \mathrm{~N} / 3 \mathrm{E}-1 \mathrm{M} 3$ & ${ }^{2}$ LLO4-3 & & 350 & 330 & 350 & $2,410.00$ & $1 / 18 / 2011$ \\
\hline $12 \mathrm{~N} / 3 \mathrm{E}-1 \mathrm{M} 4$ & LL04B-1 & & 490 & 470 & 490 & $2,410.00$ & $2 / 25 / 2011$ \\
\hline $12 \mathrm{~N} / 3 \mathrm{E}-1 \mathrm{M} 5$ & LL04B-2 & & 350 & 330 & 350 & $2,410.00$ & $2 / 25 / 2011$ \\
\hline $13 \mathrm{~N} / 3 \mathrm{E}-14 \mathrm{~K} 1$ & LW1-100 & & 105 & 80 & 100 & $2,211.20$ & $5 / 8 / 1995$ \\
\hline $13 \mathrm{~N} / 3 \mathrm{E}-23 \mathrm{~F} 1$ & LX-1 & & 585 & 95 & 575 & $2,170.03$ & $10 / 12 / 1980$ \\
\hline $13 \mathrm{~N} / 3 \mathrm{E}-23 \mathrm{P} 1$ & ${ }^{3} \mathrm{LP}-3$ & L-1 & 562 & 52 & 552 & $2,173.52$ & $12 / 9 / 1980$ \\
\hline $13 \mathrm{~N} / 3 \mathrm{E}-24 \mathrm{~N} 1$ & LL3 & & 172 & 152 & 172 & $2,161.73$ & $2 / 10 / 2002$ \\
\hline $13 \mathrm{~N} / 3 \mathrm{E}-26 \mathrm{~K} 1$ & ${ }^{4} \mathrm{LP}-2$ & L-2 & 660 & 160 & 440 & $2,180.86$ & $3 / 24 / 1989$ \\
\hline $13 \mathrm{~N} / 3 \mathrm{E}-26 \mathrm{~K} 2$ & LL1-780 & & 780 & 760 & 780 & $2,172.46$ & $5 / 7 / 1995$ \\
\hline $13 \mathrm{~N} / 3 \mathrm{E}-26 \mathrm{~K} 3$ & LL1-420 & & 420 & 400 & 420 & $2,172.46$ & $5 / 7 / 1995$ \\
\hline $13 \mathrm{~N} / 3 \mathrm{E}-26 \mathrm{~K} 4$ & LL1-210 & & 210 & 190 & 210 & $2,172.46$ & $5 / 7 / 1995$ \\
\hline \multirow[t]{2}{*}{$13 \mathrm{~N} / 3 \mathrm{E}-26 \mathrm{~N} 1$} & L-3 & & 370 & ${ }^{6} 340$ & ${ }^{6} 360$ & $2,261.67$ & $2 / 20 / 1988$ \\
\hline & & & & 145 & 300 & & \\
\hline \multirow[t]{2}{*}{$13 \mathrm{~N} / 3 \mathrm{E}-26 \mathrm{~N} 2$} & ${ }^{2} \mathrm{TH}-8$ & & 370 & ${ }^{6} 340$ & ${ }^{6} 360$ & $2,263.15$ & $12 / 28 / 1987$ \\
\hline & & & & 145 & 300 & & \\
\hline 13N/3E-34Q1 & TH-10 & & 295 & 240 & 285 & $2,357.26$ & $12 / 30 / 1987$ \\
\hline $13 \mathrm{~N} / 3 \mathrm{E}-35 \mathrm{~A} 1$ & ${ }^{5} \mathrm{LP}-1$ & L-3 & 703 & 160 & 580 & $2,200.27$ & $3 / 16 / 1989$ \\
\hline $13 \mathrm{~N} / 3 \mathrm{E}-35 \mathrm{~B} 1$ & L-1 & & 500 & 100 & 482 & $2,198.37$ & $12 / 1954$ \\
\hline $13 \mathrm{~N} / 3 \mathrm{E}-35 \mathrm{~J} 1$ & LL2-699 & & 699 & 659 & 699 & $2,250.75$ & $2 / 9 / 2002$ \\
\hline $13 \mathrm{~N} / 3 \mathrm{E}-35 \mathrm{~J} 2$ & LL2-415 & & 415 & 395 & 415 & $2,250.75$ & $2 / 9 / 2002$ \\
\hline $13 \mathrm{~N} / 3 \mathrm{E}-35 \mathrm{~J} 3$ & LL2-190 & & 190 & 170 & 190 & $2,250.75$ & $2 / 9 / 2002$ \\
\hline
\end{tabular}




\section{Geologic Units}

For this study, the geologic units of Miller and others (2013) are grouped into four generalized stratigraphic units: (1) basement complex of pre-Tertiary felsic and mafic granitic rocks and metamorphic rocks consisting of marble, quartzite, and schist; (2) Tertiary sedimentary deposits; (3) QuaternaryTertiary older alluvium; and (4) Quaternary younger alluvium (figs. 2 and 3). The Tertiary sedimentary deposits, QuaternaryTertiary older alluvium; and Quaternary younger alluvium form the water-bearing deposits in the Langford Basin. These deposits are unconsolidated at land surface and become semiconsolidated to consolidated with depth. The reported thicknesses of these units were based on an analysis of driller's logs compiled or drilled as part of this study.

The basement complex underlies the Langford Basin and crops out in some of the surrounding hills, predominantly to the west, north, and northeast (figs. 2 and 3). In general, the basement complex has very low permeability, and water is present only where these rocks are extensively jointed, fractured, or weathered. Although this "weathered" zone may contain moderate quantities of extractable water, storage is minimal, and the basement complex is considered a nonwater-bearing zone.

Tertiary sedimentary deposits (figs. 2 and 3; Tyg and Tog) overlie the basement complex and form low-lying hills south and southeast of the basin. These deposits consist of crudely bedded sands and gravels that are primarily derived from granitic rocks. The Tertiary sedimentary deposits are subdivided into Tertiary younger sedimentary deposits (Tyg) and Tertiary older sedimentary deposits (Tog), on the basis of the degree of consolidation observed during well drilling (fig. 3). The Tertiary older sedimentary deposits overlie the basement complex in most of the Langford Basin (fig. 3) and consist of consolidated arkosic sandstone and conglomerate. In general, the Tertiary older sedimentary deposits are overlain by Tertiary younger sedimentary deposits. The Tertiary younger sedimentary deposits are unconsolidated but are generally less permeable than the overlying Quaternary deposits. However, where sand and gravel predominate, the Tertiary deposits, in general, may yield moderate amounts of water to wells.

The Quaternary older alluvium (figs. 2 and 3; Qoa) overlies the Tertiary deposits and consists of sand, gravel, and clay. The clasts in this deposit vary with nearby source rocks; they are primarily derived from quartzite, granite, and marble in the northern part of the basin near Garlic Spring and from granitic rocks in the southern part of the basin. The Quaternary older alluvium, in small areas to the southwest and northeast of the basin, typically is cemented by calcite in its upper 10-20 ft where exposed at the surface. The Quaternary older alluvium is more indurated and slightly less permeable than the overlying Quaternary younger alluvium but still yields moderate amounts of water.

The Quaternary younger alluvium (Qya), younger eolian deposits (Qye), and playa deposits (Qp) (figs. 2 and 3) overlie the Quaternary older alluvium throughout the basin. These deposits, as a group, are composed of unconsolidated sand and gravel with some pedogenic silt and clay. The Quaternary younger alluvium is coarser grained near the hills and becomes finer grained and better sorted toward the Langford Well Lake (dry) playa. The Quaternary younger alluvium generally is less than $20 \mathrm{ft}$ thick and lies above the water table (figs. $3 A$ and $3 B$ ).

Quaternary playa deposits (figs. 2 and $3 C$; Qp) underlie the surface of Langford Well Lake (dry) in the northeastern part of the basin. The Quaternary playa deposits consist of moderately sorted clay, silt, and fine sand and may be as much as $100 \mathrm{ft}$ thick. The Quaternary playa deposits are interfingered with the Quaternary younger alluvium and extend into the Quaternary older alluvium. The Quaternary playa deposits are fine grained and have a very low permeability. Because of the low permeability, infiltration of surface water is impeded and water ponds on the playa after an occasional storm; the ponded water generally evaporates.

A thin layer of eolian deposits (fig. 2; Qye) is present along the western edge of the playa (fig. $3 B$ ). These deposits, consisting of loose sand that was deposited by wind, are not saturated and are not a source of groundwater. Because eolian deposits tended to form near ancient playas, similar deposits may be buried.

\section{Depth to the Basement Complex}

A gravity survey was done, as part of this study, to help understand the three-dimensional structure and to help estimate the depth to the basement complex (thickness of basin fill) in the study area (Smith, 1997; Morin, 2000). The gravity survey includes measurements at 290 gravity stations (shown in fig. 2 in Morin, 2000). Estimating the depth to the basement complex from gravity data requires knowledge of the residual gravity field of the exposed geology and knowledge of the vertical density variation within the basin deposits. In addition, data from boreholes that penetrate the surface of the basement complex and surficial geophysical data, including seismic refraction (David Berger, U.S. Geological Survey, written commun., 1996) and time-domain electromagnetic (Burgess and Bedrosian, 2013) data, provide constraints on the estimated thickness of the basin fill. These geophysical data were used to map the depth to the water table, the contact between water-bearing alluvial deposits and non-water-bearing Tertiary sediments, and changes in water salinity with depth. For detailed information regarding the gravity survey and analysis, the reader is referred to Smith (1997) and Morin (2000).

The estimated altitude of the basement complex in the Langford Basin shows there are three deep areas within the basin with a minimum altitude of $1,000 \mathrm{ft}$ above NAVD 88 or less (fig. 4). The deepest area is beneath Langford Well Lake (dry) playa, at an altitude of about $600 \mathrm{ft}$ above NAVD 88, in the northeastern part of the basin. The other two deep areas are about $1 \mathrm{mi}$ southwest and $2 \mathrm{mi}$ south of the playa. A ridge separates these two areas and could represent a buried fault. The thickness of the basin fill exceeds $1,000 \mathrm{ft}$ in each of the three areas (fig. 3). 


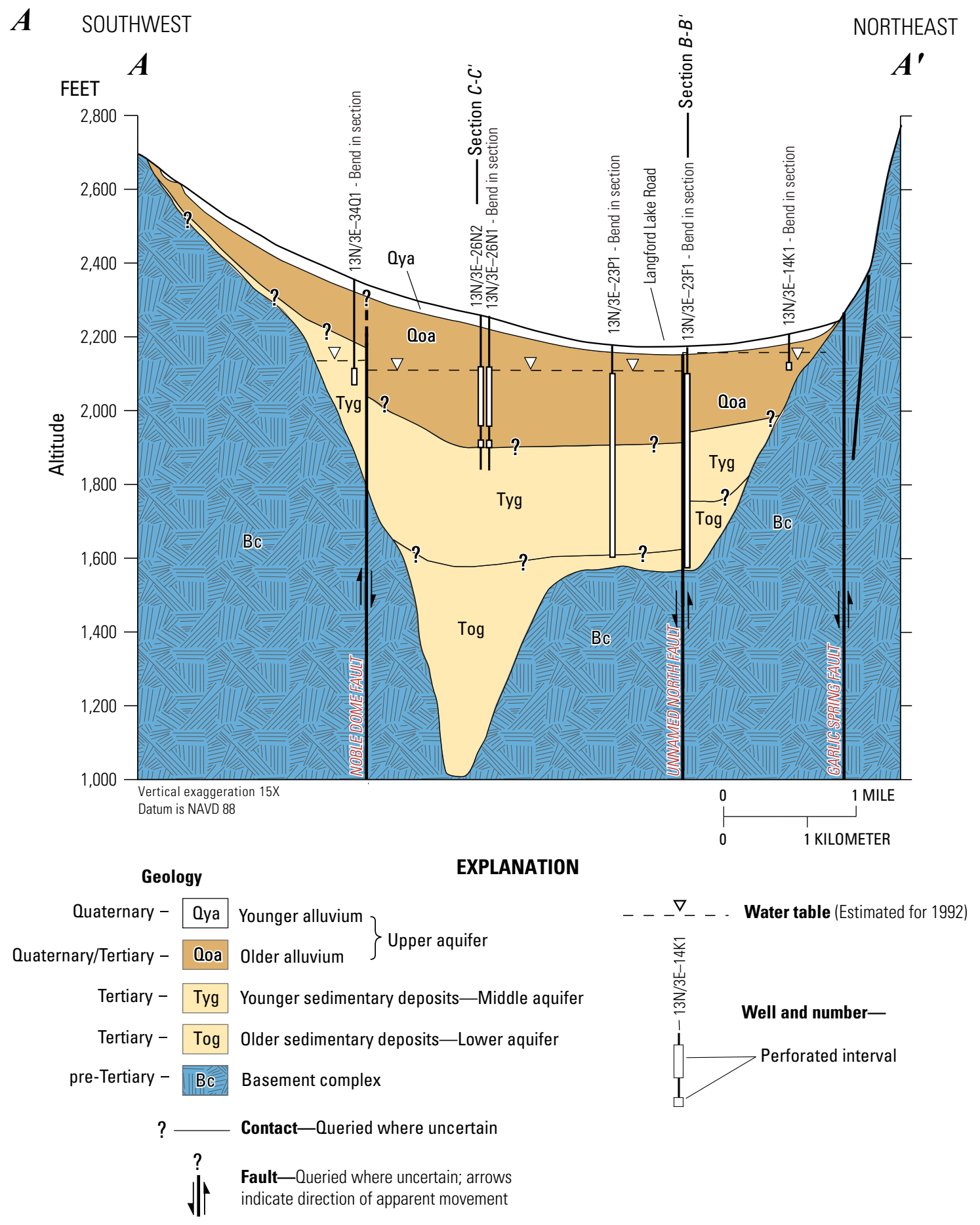

Figure 3. Generalized geologic sections $A, A-A^{\prime} ; B, B-B^{\prime} ;$ and $C, C-C^{\prime}$ across Langford Basin, Fort Irwin National Training Center, California. 
B NORTHWEST

SOUTHEAST
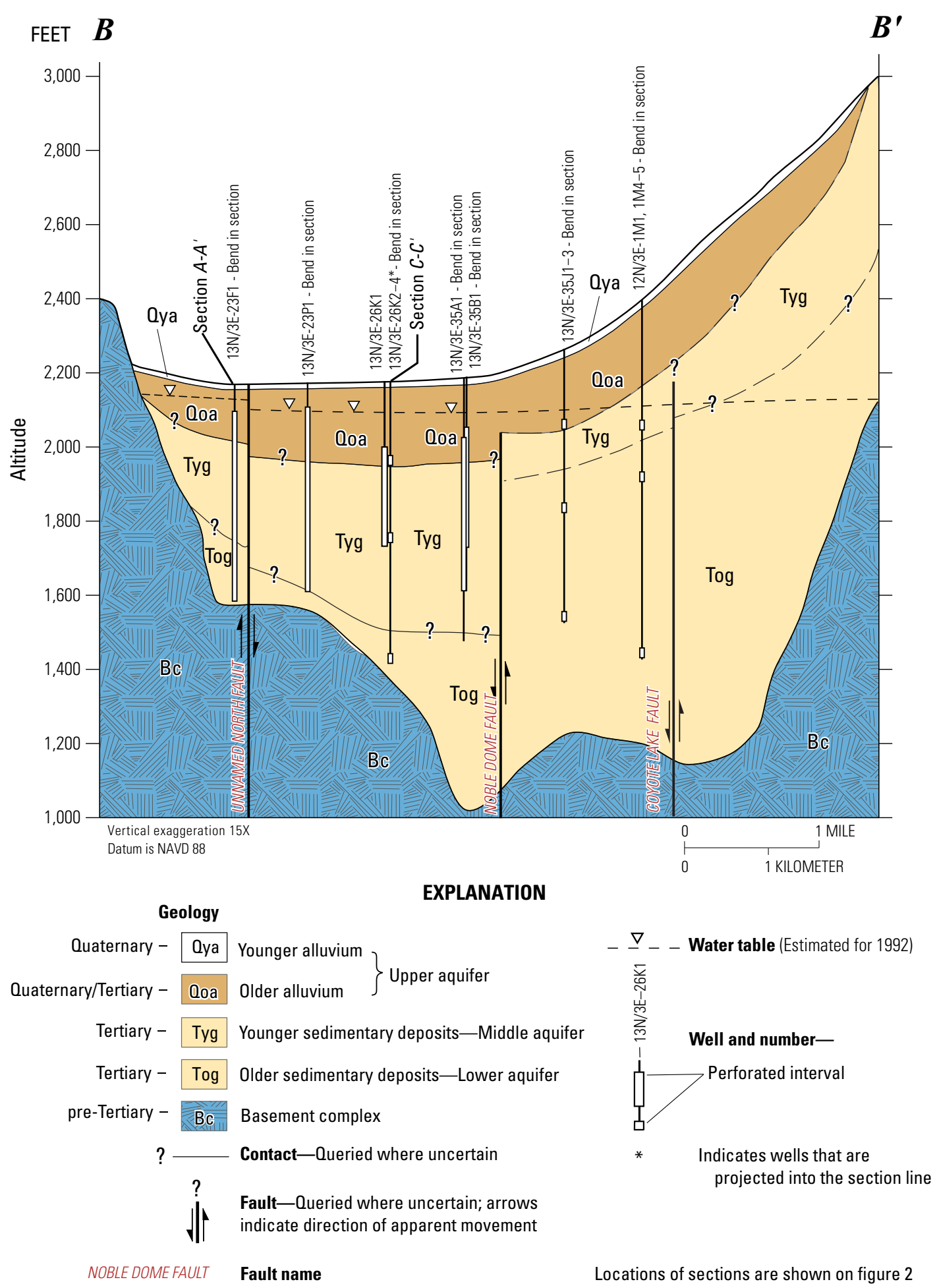

Figure 3. Generalized geologic sections $A, A-A^{\prime} ; B, B-B^{\prime}$; and $C, C-C^{\prime}$ across Langford Basin, Fort Irwin National Training Center, California.-Continued 

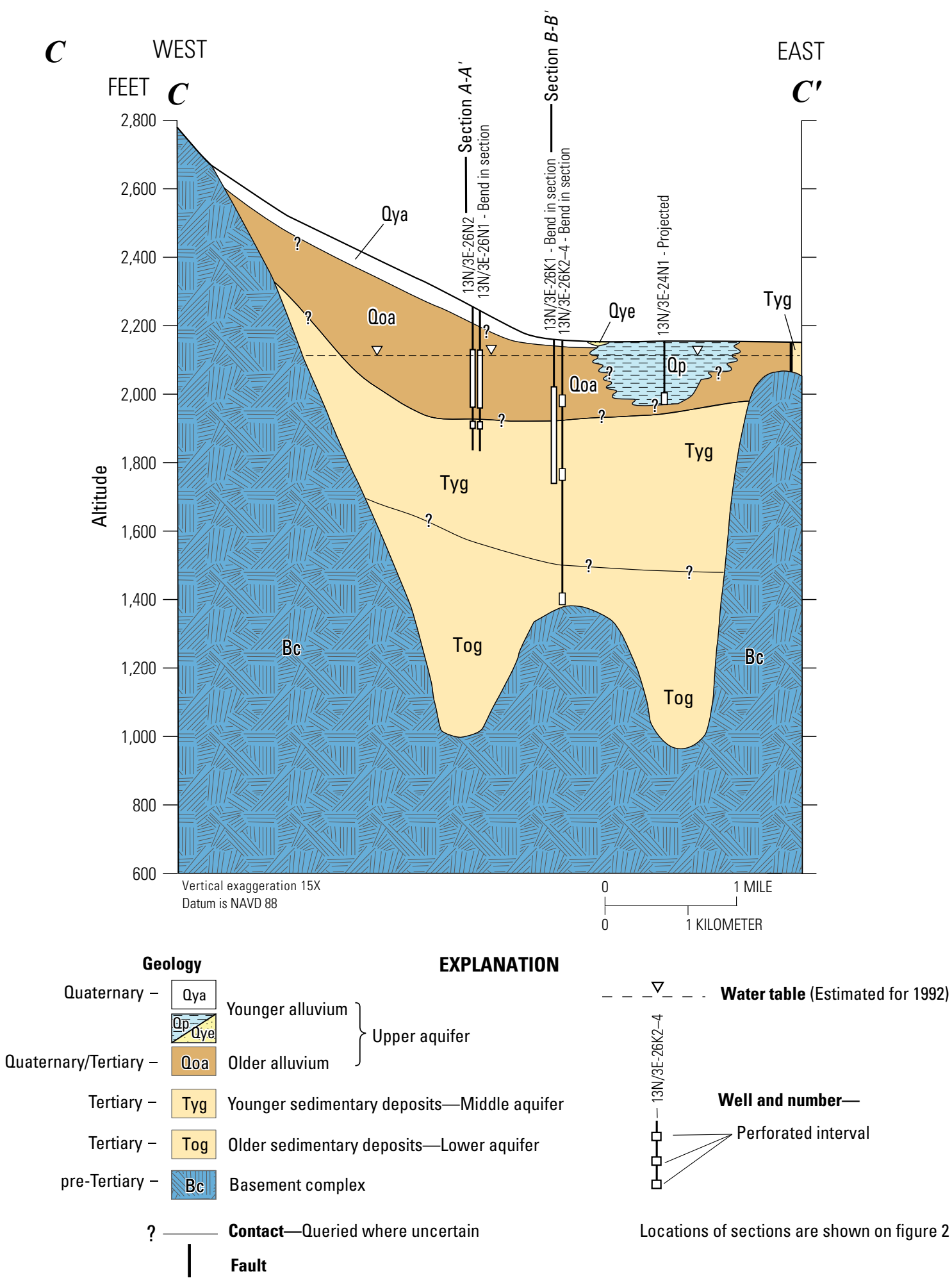

Locations of sections are shown on figure 2

Figure 3. Generalized geologic sections $A, A-A^{\prime} ; B, B-B^{\prime}$; and $C, C-C^{\prime}$ across Langford Basin, Fort Irwin National Training Center, California.-Continued 

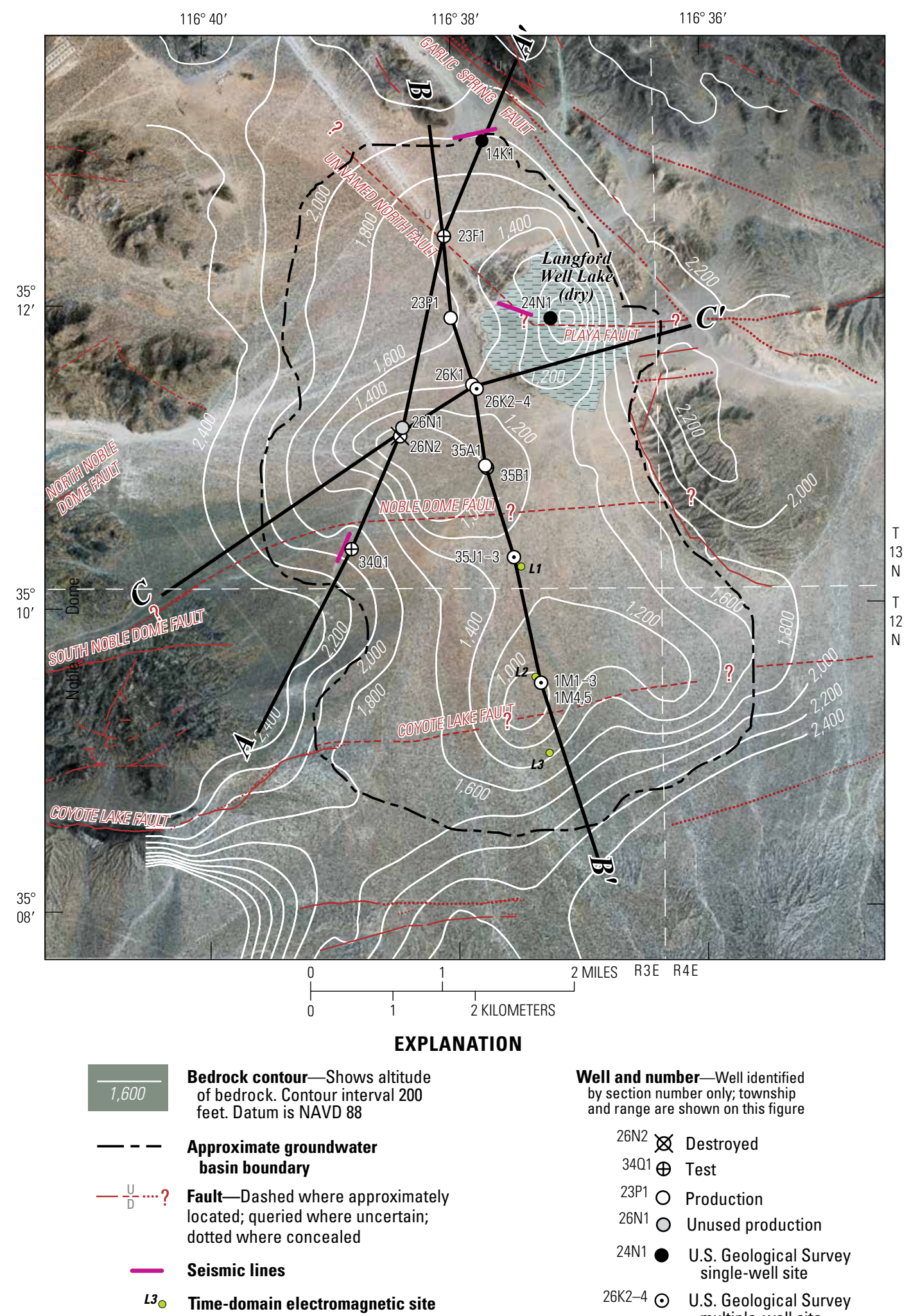

Well and number-Well identified
by section number only; township by section number only; township
and range are shown on this figure

$$
\begin{aligned}
& \text { 26N2 } \nsim \text { Destroyed } \\
& 3401 \oplus \text { Test } \\
& { }^{23 P 1} \bigcirc \text { Production } \\
& { }^{26 N 1} \mathrm{O} \text { Unused production } \\
& \text { 24N1 U.S. Geological Survey } \\
& \text { 26K2-4 } \odot \quad \text { U.S. Geological Survey }
\end{aligned}
$$

Figure 4. Altitude of the basement complex in Langford Basin, Fort Irwin National Training Center, California, based on gravity measurements. 


\section{Faults}

Faults control much of the physiography of the Fort Irwin NTC and probably control the shape of Langford Basin (Yount and others, 1994; Morin, 2000; Miller and Yount, 2002). Many faults in the Langford Basin area have been active during the Quaternary; few have demonstrated Holocene rupture, and none are considered to be a seismic risk (Miller and others, 1994). Several faults have been mapped in the bedrock hills around the Langford Basin, including the Garlic Spring, North Noble Dome, South Noble Dome, and Coyote Lake Faults (Yount and others, 1994; Schermer and others, 1996; Miller and Yount, 2002) (fig. 2). However, the precise locations of these faults are uncertain in the Langford Basin. The locations of the faults, where they are obscured by buried sediment, were approximated by projecting the mapped trace of these faults into the basin. Additionally, data collected for this study, including gravity surveys, water-level measurements, and groundwater-flow model calibration, were used to refine the locations of previously mapped faults and define the locations of previously unmapped faults within the Langford Basin.

The Garlic Spring Fault is a northwest-southeast trending fault near the northeastern boundary of the basin, where the basement complex is uplifted on the northeast side of the fault (figs. 2 and 3). The North Noble Dome, South Noble Dome, and Coyote Lake Faults are east-west trending faults mapped in the Noble Dome pediment (a flat bedrock surface at the base of Noble Dome) southwest of the Langford Basin. On the basis of differences in water-level measurements and gravity data collected during this study, an east-west trending fault is projected to extend from Noble Dome into the Langford Basin, just south of wells 13N/3E-35A1 and 13N/3E-35B1, and is referred to as the Noble Dome Fault in this report. The basin fill appears to be uplifted on the south side of the Noble Dome Fault relative to the north side (fig. $3 A$ and $3 B$ ). The Noble Dome Fault impedes groundwater flow between the central and southern parts of the basin. The Coyote Lake Fault is an east-west trending fault in the southern part of the basin (fig. 2). The basement complex and Tertiary sedimentary deposits are uplifted on the south side of the fault (David Miller, U.S. Geological Survey, oral commun., 2004; fig. 3B). Data are not available to determine if the Coyote Lake Fault is a barrier to groundwater flow.

Two additional faults, referred to as the Playa and unnamed north faults (fig. 2), were identified in the northern part of the Langford Basin on the basis of water-level and gravity data (see "Groundwater Levels and Flow" and "Depth to Basement Complex" sections, respectively), and their locations were refined on the basis of the groundwater-flow model calibration as described in the "Model Calibration" section of this report. These two faults appear to impede the flow of groundwater between the northern and central parts of the Langford Basin. The playa fault (fig. 2) trends east-west and is projected as a continuation of mapped faults east of the basin. The playa fault crosses through Langford Well Lake (dry) playa and may intersect the unnamed north fault (fig. 2) near the western edge of the playa. The unnamed north fault (fig. 2) is projected to follow the same trend as the Garlic Spring Fault to the northeast. The unnamed north fault is just west of wells 13N/3E-23F1 and 13N/3E-24N1 (fig. 2) and is aligned with an unnamed fault identified in the Irwin Basin by Densmore and Londquist (1997).

\section{Groundwater Hydrology}

The Langford Basin aquifer system was defined from information contained in previous studies, geophysical investigations conducted for this study in the basin, and geohydrologic data collected from existing and newly installed wells in the basin. As part of this study, 11 monitor wells were installed to update and refine the understanding of the geohydrologic framework of the Langford Basin (fig. 2, table 1). During 1995 , one piezometer was installed in the northern part of the basin $(13 \mathrm{~N} / 3 \mathrm{E}-14 \mathrm{~K} 1)$, and three piezometers were installed at a multiple-well site southwest of the Langford Well Lake (dry) playa (13N/3E-26K2, 13N/3E-26K3, and 13N/3E-26K4). During 2002, one piezometer was installed in the middle of the Langford Well Lake (dry) playa (13N/3E-24N1), and three piezometers were installed at a multiple-well site in the central part of the basin, south of the Noble Dome Fault (13N/3E35J1, 13N/3E-35J2, and 13N/3E-35J3). During 2011, three piezometers were installed at a multiple-well site in the southern part of the basin, north of the Coyote Lake Fault (12N/3E$1 \mathrm{M} 1,12 \mathrm{~N} / 3 \mathrm{E}-1 \mathrm{M} 4$, and 12N/3E-1M5). A typical multiplewell monitoring site in Langford Basin consists of two or three 2-in. diameter polyvinyl chloride (PVC) piezometers. Each piezometer has a single 20 - or 40 -ft screened interval, installed at different depths in the same borehole. The design of each multiple-well monitoring site was determined during well construction by examining the drill cuttings collected during drilling and the borehole geophysical logs. The lithologic logs of the drill cuttings and the geophysical logs from each borehole are presented in appendix 1.

\section{Aquifer System Definition}

The Langford Basin aquifer system consists of three aquifers, referred to in this report as the upper aquifer, middle aquifer, and lower aquifer. The upper aquifer is consists of the saturated part of the younger Quaternary alluvium and the Quaternary older alluvium, and generally is unconfined. The upper aquifer has a saturated thickness of about $200 \mathrm{ft}$ near well 13N/3E-23F1 and pinches out at the margins of the basin (fig. 3). The middle aquifer is composed of Tertiary younger sedimentary deposits and generally is confined or partly confined. The middle aquifer is as much as $440 \mathrm{ft}$ thick and is generally less permeable than the upper aquifer. The lower aquifer is composed of Tertiary older sedimentary deposits, and the thickness ranges from 40 to $1,000 \mathrm{ft}$. The base of the lower aquifer system is considered to be the top of the basement complex. The areal extent of the Langford Basin 
was delineated on the basis of the altitude at which the 1992 groundwater-level altitude intersects the bottom of the basement complex. The 1992 groundwater levels were selected because the groundwater system was undeveloped at that time. Thus, the areal extent of the Langford Basin for this study differs from that of previous studies (for example, Wilson F. So and Associates (1989)).

The transmissivity and hydraulic conductivity of the upper and middle aquifers were estimated from historical specificcapacity data. Thomasson and others (1960) reported that for unconfined valley-fill deposits in the Sacramento Valley, California, the specific capacity in units of gallons per minute of discharge per foot of drawdown in the well, multiplied by 230 , approximates the transmissivity of the aquifer in units of feet squared per day. This empirical relation between specific capacity and transmissivity from studies of the northern California aquifer was assumed to be representative of the upper and middle aquifers in the Langford Basin study area because these sediments were deposited in a similar depositional environment as the sediments in Sacramento Valley. Additionally, there is not enough information to indicate a large difference in hydraulic conductivity between the upper and middle aquifers; thus, the upper and middle aquifers were assumed to have similar values. Specific-capacity tests were conducted at eight wells perforated in the upper and middle aquifers, except well 13N/3E-23F1, which is perforated in all three aquifers, in Langford Basin (C.F. Hostrup and Associates, 1955; James M. Montgomery and Associates, 1981; Wilson F. So and Associates, 1989; Southern California Edison Company, written comm., 1992). The calculated specific capacity for wells in Langford Basin ranged from about 2.1 to $19(\mathrm{gal} / \mathrm{min}) / \mathrm{ft}$, and the estimated transmissivity ranged from 480 to $4,400 \mathrm{ft}^{2} / \mathrm{d}$ (table 2 ). The hydraulic conductivity of the upper and the middle aquifers was estimated by dividing the estimated transmissivity of the aquifers by the saturated thickness of each aquifer (table 2). The estimated transmissivity is an average for all the aquifer intervals opposite the screened intervals of the well. Hydraulic conductivities for the upper and middle aquifers estimated by this method ranged from 1 to $30 \mathrm{ft} / \mathrm{d}$. Specific capacity was not calculated for the lower aquifer. On the basis of grain size from lithologic cuttings and characteristics during drilling, the hydraulic conductivity for the lower aquifer was estimated to be about $2 \mathrm{ft} / \mathrm{d}$.

\section{Recharge and Discharge}

Previous investigators have estimated the annual recharge to the Langford Basin aquifer system to range from negligible (James M. Montgomery and Associates, 1981) to in excess of 700 acre-ft (Wilson F. So and Associates, 1989) from all sources. Because annual precipitation in Langford Basin is less than 7 in., recharge derived from precipitation is minimal. The Langford Basin aquifer system is recharged along normally dry washes near the base of the surrounding hills during precipitation events, primarily in the winter or after short summer thunderstorms. Although some of the surface runoff collects in the Langford Well Lake (dry) playa, a low area in Langford Basin, recharge from this source is negligible because of the low permeability of the playa sediments.

The Langford Basin aquifer system is recharged by groundwater underflow from the Irwin Basin through alluvial materials that connect the basins beneath an unnamed dry wash that lies parallel to the Garlic Spring Fault (fig. 2). The driller's log from monitoring well 13N/3E-14K1, in the northern part of the Langford Basin (fig. 2), indicates that the wash is underlain by about $97 \mathrm{ft}$ of alluvial material where it enters

Table 2. Results of aquifer tests conducted in Langford Basin, Fort Irwin National Training Center, California.

[Location of wells shown in figure 2. Abbreviations: gal/min/ft, gallon per minute per foot; $\mathrm{ft}^{2} / \mathrm{d}$, foot squared per day; ft, foot; ft/d, foot per day; -, no data; ?, test date not published; Qoa, Quaternary older alluvium; Tyg, Tertiary younger sedimentary deposits; Tog, Tertiary older sedimentary deposits]

\begin{tabular}{|c|c|c|c|c|c|c|c|c|}
\hline $\begin{array}{l}\text { Local well } \\
\text { name }\end{array}$ & $\begin{array}{c}\text { State well } \\
\text { number }\end{array}$ & $\begin{array}{l}\text { Date tested } \\
\text { (month year) }\end{array}$ & $\begin{array}{c}\text { Tested } \\
\text { by }\end{array}$ & $\begin{array}{c}\text { Specific } \\
\text { capacity } \\
\text { (gal/min/ft) }\end{array}$ & $\begin{array}{c}\text { Transmissivity } \\
\left(\mathrm{ft}^{2} / \mathrm{d}\right)\end{array}$ & $\begin{array}{l}\text { Saturated } \\
\text { thickness' } \\
\text { (ft) }\end{array}$ & $\begin{array}{l}\text { Hydraulic } \\
\text { conductivity } \\
\text { (ft/d) }\end{array}$ & $\begin{array}{l}\text { Aquifer the well } \\
\text { is screened in }\end{array}$ \\
\hline LX-1 & $13 \mathrm{~N} / 3 \mathrm{E}-23 \mathrm{~F} 1$ & Oct 80 & Driller $^{3}$ & 3.8 & 870 & 480 & 2 & $\begin{array}{l}\text { Qoa, Tyg, } \\
\text { Tog }\end{array}$ \\
\hline \multirow[t]{2}{*}{ L-1 } & $13 \mathrm{~N} / 3 \mathrm{E}-35 \mathrm{~B} 1$ & $?$ & Hostrup $^{4}$ & 4.7 & 1,100 & 380 & 3 & Qoa, Tyg \\
\hline & & Nov 80 & Montgomery $^{5}$ & - & - & - & $3-10$ & \\
\hline TH-8 & $13 \mathrm{~N} / 3 \mathrm{E}-26 \mathrm{~N} 2$ & Feb 88 & $\mathrm{So}^{6}$ & 5.2 & 1,200 & 180 & 7 & Qoa, Tyg \\
\hline LP-1 & $13 \mathrm{~N} / 3 \mathrm{E}-35 \mathrm{~A} 1$ & Feb 92 & $\mathrm{SCE}^{7}$ & 19.0 & 4,400 & 420 & 10 & Qoa, Tyg \\
\hline LP-2 & $13 \mathrm{~N} / 3 \mathrm{E}-26 \mathrm{~K} 1$ & Feb 92 & $\mathrm{SCE}^{7}$ & 9.0 & 2,100 & 280 & 7 & Qoa, Tyg \\
\hline \multirow[t]{2}{*}{ LP-3 } & $13 \mathrm{~N} / 3 \mathrm{E}-23 \mathrm{P} 1$ & Feb 92 & $\mathrm{SCE}^{7}$ & 4.8 & 1,100 & 400 & 3 & Qoa, Tyg \\
\hline & & Nov 80 & Montgomery $^{5}$ & 2.1 & 480 & 400 & 1 & \\
\hline
\end{tabular}

${ }^{1}$ The saturated thickness is from the top of the water table to the bottom of the well.

${ }^{2}$ The hydraulic conductivity is an average for all aquifers the well is sceened in.

${ }^{3}$ Data from water-well driller's log.

${ }^{4}$ C.F. Hostrup and Associates (1955).

${ }^{5}$ James M. Montgomery and Associates (1981).

${ }^{6}$ Wilson F. So and Associates (1989).

${ }^{7}$ Southern California Edison, written comm., 1992. 
the basin (appendix fig. A1-4). Prior to groundwater development in Irwin Basin, groundwater underflow out of Irwin Basin through the alluvial materials underlying the wash was estimated to be about 50 acre-ft (Densmore, 2003). Since the early 1990s, Irwin Basin has experienced a net inflow of water owing to importation of water withdrawn from the Bicycle and Langford Basins and the subsequent infiltration of treated wastewater effluent in the southeastern part of the Irwin Basin (Densmore, 2003). Groundwater levels in the wash in Irwin Basin have risen above predevelopment levels as a result of the net increase in groundwater inflow into the basin, which resulted in the annual average groundwater underflow out of the Irwin Basin increasing from about 50 acre-ft in the early 1990s to about 105 acre-ft in 1999 (Densmore, 2003). The increase in groundwater underflow from the Irwin Basin does not immediately become recharge to the Langford Basin because of the more than $1 \mathrm{mi}$ distance between the basins (fig. 1). In addition, some of the underflow probably is lost to evapotranspiration by phreatophytes near Garlic Spring. Therefore, the total groundwater underflow into the Langford Basin probably is less than the total groundwater underflow out of the Irwin Basin. The groundwater-flow model developed for this study, described in the "Simulation of Groundwater Flow" section of this report, was used to estimate the quantity and timing of groundwater underflow into the Langford Basin.

Groundwater underflow discharges from Langford Basin beneath an unnamed, highly faulted, low-lying rise east of the Langford Well Lake (dry) playa (fig. 2). Geomorphic evidence, observed in a high-resolution aerial photo covering Langford Basin and adjacent West Cronise Valley, indicates that a wash discharged toward West Cronise Valley. The wash is at the lowest elevation in the Langford Basin and West Cronise Valley (U.S. Geological Survey, 2012), and the wash is the only area where surface water can flow out of the Langford Basin. It is believed that surface water discharged from Langford Basin through this wash, and underflow flowed through the faulted section. Before groundwater development began in 1992, groundwater underflow was the only discharge from the basin. Evaporation of groundwater beneath Langford Well Lake (dry) playa is negligible because the water table is more than $30 \mathrm{ft}$ below land surface. Prior to 1992, the Langford Basin was considered to be in steady-state conditions, with discharge equal to recharge to the basin.

\section{Groundwater Withdrawals and Water Use}

Groundwater withdrawals in Langford Basin began in 1992 when three production wells (13N/3E-23P1, 13N/3E-26K1, and 13N/3E-35A1; fig. 2) were installed in a north-south line west of the playa (fig. 2). Groundwater withdrawn from the wells is transported through a pipeline to Irwin Basin, where it is blended with the water withdrawn from Irwin and Bicycle Basins and is used in Irwin Basin. None of the water that is withdrawn from Langford Basin is used in or returned to Langford Basin.
Groundwater withdrawals are metered and recorded on a monthly basis by Fort Irwin personnel. Between April 1992 and December 2010, an average of 648 acre-ft/yr of water was withdrawn from Langford Basin (table 3). Average annual withdrawal rates were 101, 219, and 329 acre-ft/yr from production wells $13 \mathrm{~N} / 3 \mathrm{E}-23 \mathrm{P} 1,13 \mathrm{~N} / 3 \mathrm{E}-26 \mathrm{~K} 1$, and $13 \mathrm{~N} / 3 \mathrm{E}-35 \mathrm{~A} 1$, respectively. Total annual groundwater withdrawals ranged from about 133 to 1,006 acre-ft/yr (table 3 and fig. 5A). During the 19-year period from April 1992 through December 2010, groundwater withdrawals were highest during June, July, August, and September, accounting for about 50 percent of the average annual withdrawals (fig. 6).

\section{Groundwater Levels and Flow}

Water levels measured during the 1980s at wells $13 \mathrm{~N} / 3 \mathrm{E}-$ 23F1, 26N1, 26N2, 34Q1, and 35B1 are considered to represent predevelopment conditions in the Langford Basin (fig. 7A). The predevelopment groundwater gradient was relatively flat, with a general direction of groundwater flow beneath Langford Well Lake (dry) playa, and groundwater discharges from the basin east of the playa as underflow through the heavily faulted, low-lying hills (fig. 2). The predevelopment groundwater-level (or water-table) altitude was about $2,114 \mathrm{ft}$ near the playa. Groundwater levels were relatively stable prior to the initiation of pumping in 1992 (fig. 5B).

Table 3. Summary of annual groundwater withdrawals, in acre-feet per year, from three wells in Langford Basin, Fort Irwin National Training Center, California, April 1992-December 2010.

\begin{tabular}{|c|c|c|c|c|}
\hline Year & 13N/3E-23P1 & 13N/3E-26K1 & 13N/3E-35A1 & Total \\
\hline${ }^{1} 1992$ & 45.9 & 149.9 & 364.7 & 560.5 \\
\hline 1993 & 94.6 & 427.9 & 483.4 & $1,005.9$ \\
\hline 1994 & 82.1 & 213.4 & 609.1 & 904.6 \\
\hline 1995 & 23.7 & 155.6 & 553.1 & 732.4 \\
\hline 1996 & 138.6 & 223.1 & 232.7 & 594.4 \\
\hline 1997 & 70.6 & 188.9 & 550.5 & 810.0 \\
\hline 1998 & 209.5 & 175.9 & 264.1 & 649.5 \\
\hline 1999 & 110.0 & 142.0 & 221.0 & 473.0 \\
\hline 2000 & 145.9 & 203.8 & 232.5 & 582.2 \\
\hline 2001 & 70.4 & 46.9 & 116.8 & 234.1 \\
\hline 2002 & 75.1 & 211.2 & 97.4 & 383.7 \\
\hline 2003 & 46.4 & 239.6 & 332.0 & 618.0 \\
\hline 2004 & 19.5 & 199.6 & 276.0 & 495.1 \\
\hline 2005 & 169.1 & 236.9 & 276.7 & 682.7 \\
\hline 2006 & 209.2 & 355.8 & 337.9 & 902.9 \\
\hline 2007 & 50.2 & 82.5 & 0.0 & 132.7 \\
\hline 2008 & 212.8 & 411.6 & 230.4 & 854.8 \\
\hline 2009 & 66.4 & 215.5 & 510.1 & 792.0 \\
\hline 2010 & 73.9 & 272.1 & 553.6 & 899.6 \\
\hline Total & $1,914.0$ & $4,152.2$ & $6,241.9$ & $12,308.1$ \\
\hline Average & 100.7 & 218.5 & 328.5 & 647.8 \\
\hline $\begin{array}{l}\text { Average } \\
\text { percent }\end{array}$ & 15.6 & 33.7 & 50.7 & 100.0 \\
\hline
\end{tabular}

'Groundwater withdrawals from April 1992 to December 1992. 


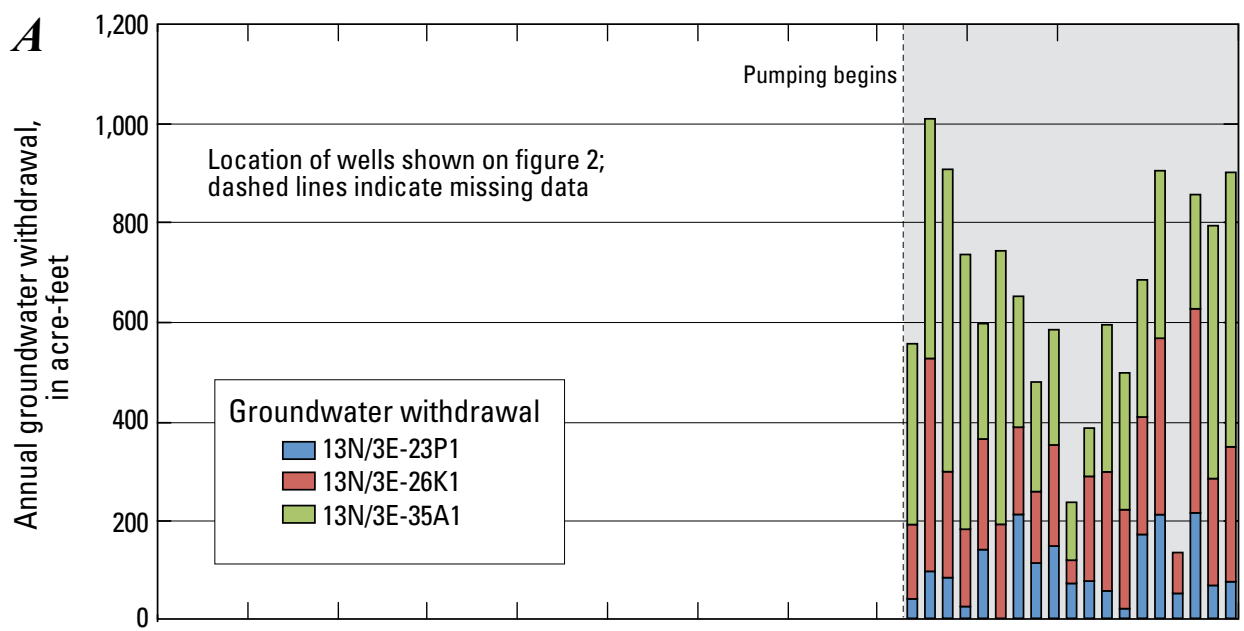

From 1992 to 2010, approximately 12,310 acre-ft of water were withdrawn from the three production wells in the basin (table 3). Water-level contours representing 1995, 2000, 2005, and 2010 conditions show that groundwater withdrawals have resulted in a cone of depression near production well $13 \mathrm{~N} / 3 \mathrm{E}-35 \mathrm{~A} 1$ in the central part of the basin (fig. $7 B, 7 C, 7 D$, and $7 E$ ). From predevelopment conditions (fig. $7 A$ ) to 2010, water-level declines were measured at all wells in the Langford Basin, with as much as $50 \mathrm{ft}$ under pumping conditions in well 13N/3E-35B1 in

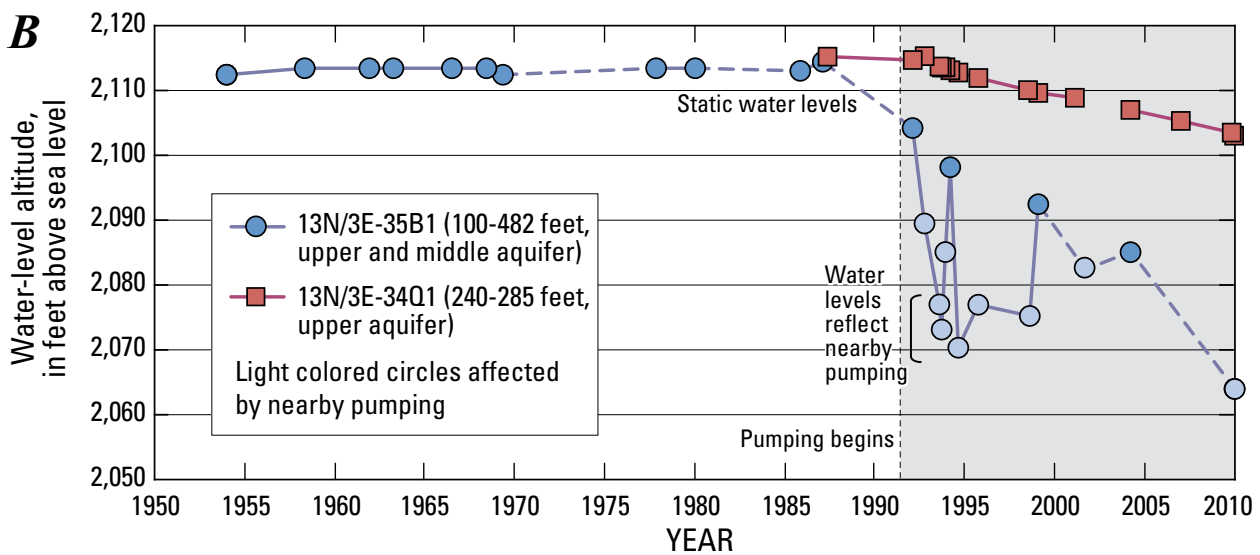
the cone of depression (figs. $5 B$ and $7 E)$.

Inspection of the groundwaterlevel contours indicates that faults within the basin impede the flow of groundwater (fig. 7). The impediment effect of these faults is likely caused by the low permeability of the fault zones resulting from the compaction and extreme deformation of the water-bearing deposits immediately adjacent to the faults and by lateral juxtaposition of highpermeability and low-permeability units. The low-permeability fault zones form a partial barrier to the

Figure 5. $A$, Groundwater withdrawal, and $B$, water-level fluctuations in selected wells in Langford Basin, Fort Irwin National Training Center, California.

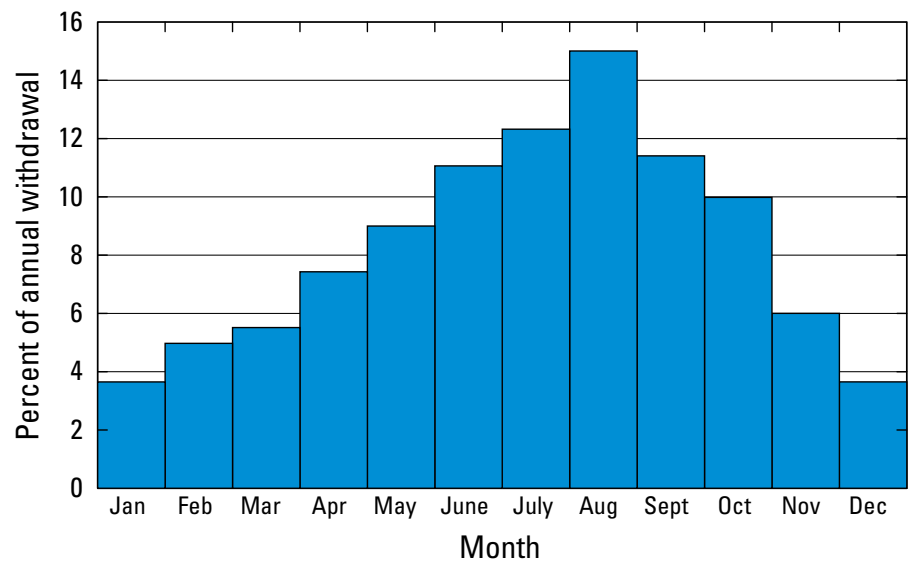

Figure 6. Monthly distribution of groundwater withdrawals, January 1993-December 2010, Langford Basin, Fort Irwin National Training Center, California. lateral movement of groundwater flow, which can cause sharp discontinuities in water-level altitudes on opposite sides of a fault. In some cases, the barrier effect of the fault is not observed until the aquifer system is stressed by groundwater pumping or recharge. Thus, the water level in a well on the other side of a fault from a production well may not respond or may have a delayed response to waterlevel changes at the production well from variations in the withdrawal rate.

\section{Groundwater Quality}

The groundwater quality of the Langford Basin was defined by collecting water-quality samples from 18 wells and 1 spring during 1993-2011 (appendix 2). Groundwater from the Langford Basin is treated prior to distribution for drinking. Three of the sites sampled were multiple-well monitoring sites that each contain three wells screened at different depths. The remaining nine wells were production wells or single-well monitoring sites. Data collected as part of this study were supplemented with historical data from wells also shown in appendix 2 (C.F. Hostrup and Associates, 1955; Kunkel and Riley, 1959; James M. Montgomery and Associates, 1981; Wilson F. So and Associates, 1989). 

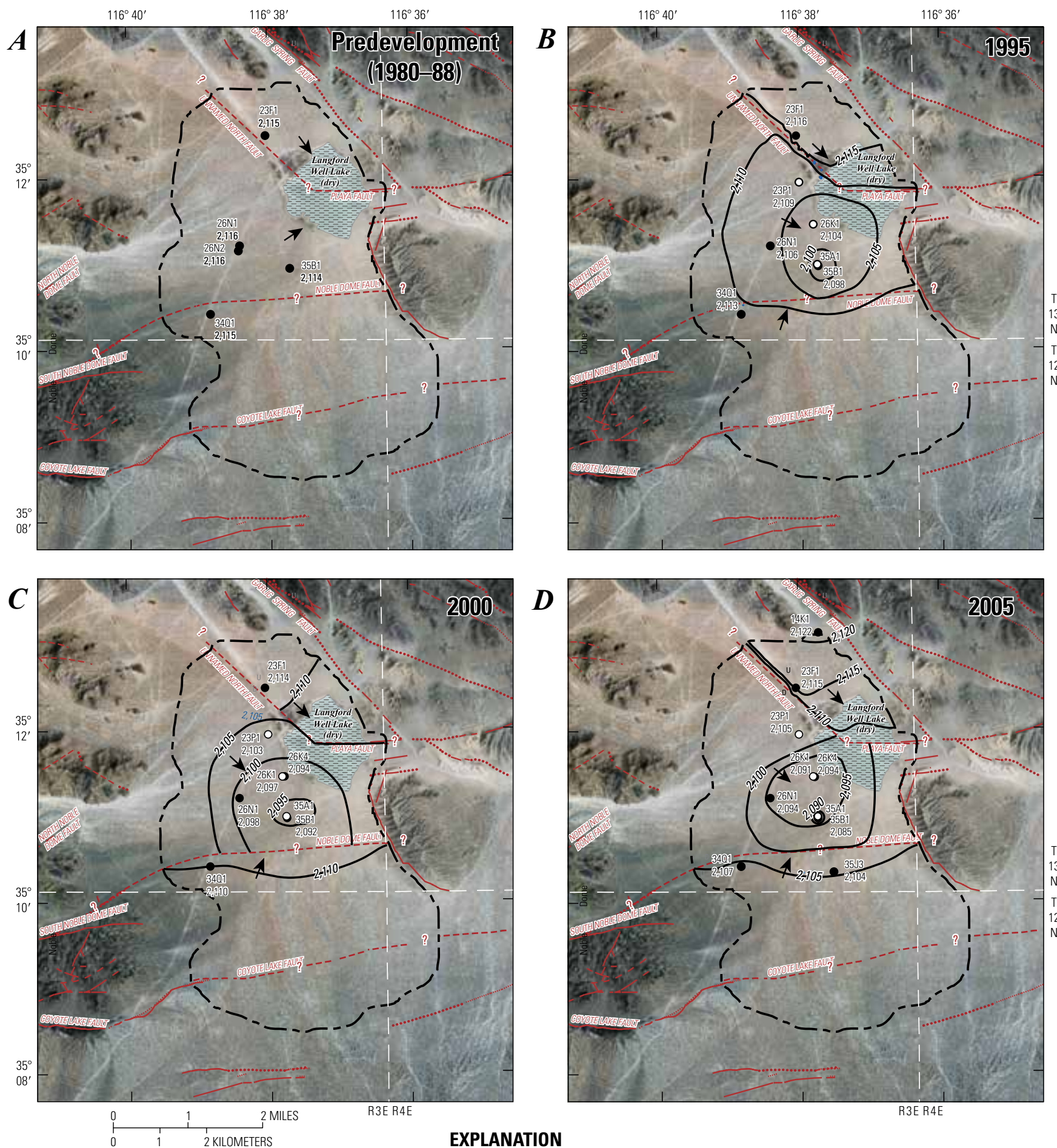

EXPLANATION

2,105 Lines of equal water-level altitude - Interval is varied. Datum is NAVD 88. Arrows show direction of groundwater flow

- - Approximate groundwater basin-Boundary from 1993 water-level altitude

$\uparrow$ Generalized direction of flow

_ $-\ldots . .$. ? Fault-Dashed where approximately located; queried where uncertain; dotted where concealed; $U$ indicates up-thrown side of fault; $D$ is down-thrown side of fault

3401 - Well and number-Top number is well section number (township and range is shown on figure). Bottom number is water-level altitude measured during year indicated, in feet above NAVD 88. White-filled circle indicates production well

Figure 7. Groundwater-level contours for $A$, predevelopment (1980-88); $B, 1995 ; C, 2000 ; D, 2005$; and $E$, 2010 in Langford Basin, Fort Irwin National Training Center, California. 


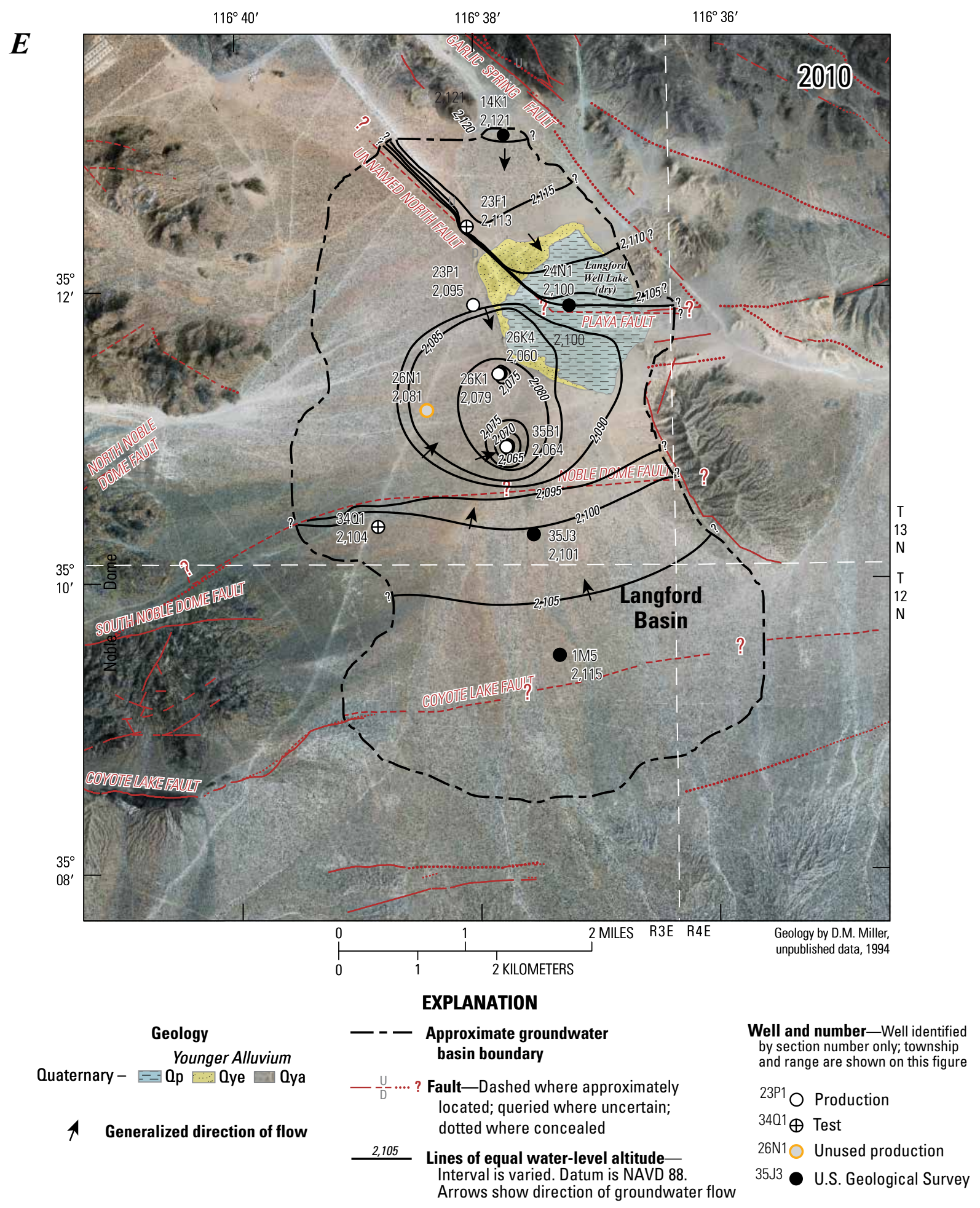

Figure 7. Groundwater-level contours for $A$, predevelopment (1980-88); $B, 1995 ; C, 2000 ; D, 2005$; and $E$, 2010 in Langford Basin, Fort Irwin National Training Center, California.-Continued 


\section{Sampling and Laboratory Methods}

Water-quality samples were analyzed in the field for specific conductance, $\mathrm{pH}$, temperature, and alkalinity, and were collected following the methods described in the USGS National Field Manual (U.S. Geological Survey, 2006). Samples were analyzed in the laboratory for major and minor ions, alkalinity, selected trace elements, nutrients, the ratios of the stable isotopes of oxygen $(\mathrm{O})$ and hydrogen $(\mathrm{H})$, and the concentrations of the radioactive isotopes tritium $\left({ }^{3} \mathrm{H}\right)$, and carbon-14 $\left({ }^{14} \mathrm{C}\right)$ (appendix 2).

Groundwater samples for major and minor ions, trace elements, alkalinity, and total dissolved solids (TDS) analyses required filling one 250-milliliter $(\mathrm{mL})$ polyethylene bottle with unfiltered groundwater and one $500-\mathrm{mL}$ and one $250-\mathrm{mL}$ polyethylene bottle with filtered groundwater (Wilde and others, 2004). Samples were filtered using a 0.45 micron Whatman capsule filter. Each $250-\mathrm{mL}$ filtered sample was preserved with 7.5 Normal nitric acid. Each nutrient sample was filtered into a $125-\mathrm{mL}$ opaque polyethylene bottle. Samples for alkalinity titrations were collected by filtering groundwater into a $500-\mathrm{mL}$ polyethylene bottle. Samples for stable isotopes were collected in $60-\mathrm{mL}$ clear glass bottles filled with unfiltered groundwater and capped; caps were secured using electrical tape to prevent leakage and evaporation. Samples for ${ }^{3} \mathrm{H}$ analysis were collected by filling $1-\mathrm{L}$ amber glass bottles with unfiltered groundwater; bottles were closed using caps with a conical insert and secured using electrical tape. ${ }^{14} \mathrm{C}$ samples were collected by filling a 1-L glass bottle from the bottom of the bottle with filtered groundwater.

All samples, except ${ }^{14} \mathrm{C}$, were analyzed at the USGS National Water Quality Laboratory (NWQL) or by laboratories contracted by the NWQL. Inorganic constituents were analyzed by the NWQL using methods described in Fishman (1993), Patton and Kryskalla (2003), Fishman and Friedman (1989), McLain (1993), and Garbarino (1999). Stable isotopes were analyzed on contract to the NWQL by the USGS Stable Isotope Laboratory in Reston, Virginia, using methods described by Epstein and Mayeda (1953), Coplen and others (1991), and Coplen (1994). ${ }^{14} \mathrm{C}$ was analyzed on contract to the NWQL by Woods Hole Oceanographic Institution, National Ocean Sciences Accelerator Mass Spectrometry Facility [NOSAMS] in Massachusetts, using methods described by Vogel and others (1987), Donahue and others (1990), Gagnon and Jones (1993), and Schneider and others (1994). Tritium was analyzed by the USGS Stable Isotope and Tritium Laboratory in Menlo Park, California, using methods described by Thatcher and others (1977). These data are stored in the USGS NWIS database and can be accessed at http://waterdata.usgs.gov/ca/nwis/nwis.

\section{General Water-Quality Characteristics}

The major-ion chemistry of groundwater in the Langford Basin is controlled by the natural chemistry of the recharge water, geochemical reactions, which are primarily dissolution and precipitation of minerals in the subsurface, and evaporation. The chemical character of groundwater sampled from selected wells and the spring was determined by using Stiff and trilinear diagrams (figs. 8 and 9). A Stiff diagram depicts the concentrations of major ions in milliequivalents per liter (fig. 8) and indicates relative proportions of major ions (Stiff, 1951). Similarly shaped Stiff diagrams indicate the presence of groundwater with similar chemical characteristics for major ions. Changes in the width of the diagrams approximate differences in the concentrations of TDS. Trilinear diagrams were plotted by using a method described by Piper (1944) to visually characterize water quality differences (water types) within the basin (fig. 9). A trilinear diagram displays the relative contribution of major cations and anions, on a charge-equivalent basis, to the total ionic content of the water. Percentage scales show cation concentrations on the upper right and lower left sides of a central diamond and the anion concentrations are shown on the opposite sides. The position of a sample on the diagram gives an indication of the chemical character of the water and allows a comparison to be made between different samples.

Stiff diagrams were plotted on a map of the study area to show the areal distribution of water quality in the basin (fig. 8). Trilinear diagrams were prepared for samples from the northern part (the area east of the unnamed north fault and north of the playa fault), the central part (the area north of the Noble Dome Fault, excluding the northern area), and the southern part (the area south of the Noble Dome Fault) of the Langford Basin (fig. 9). Samples collected prior to 1993 represent predevelopment conditions, and samples collected after 1993 represent post-development conditions.

\section{Chemical Character of Groundwater}

Groundwater samples from wells in the northern and central parts of the Langford Basin are sodium-bicarbonatesulfate $\left(\mathrm{NaHCO}_{3}-\mathrm{SO}_{4}\right)$ type waters, with the exception of wells $13 \mathrm{~N} / 3 \mathrm{E}-24 \mathrm{~N} 1,13 \mathrm{~N} / 3 \mathrm{E}-26 \mathrm{~K} 2$, and 13N/3E-35A1 (figs. 8 and 9). $\mathrm{A} \mathrm{NaHCO}_{3}-\mathrm{SO}_{4}$ type water is a water in which $\mathrm{Na}, \mathrm{HCO}_{3}$, and $\mathrm{SO}_{4}$ are the predominant ions. The wells with $\mathrm{NaHCO}_{3}^{-}$ $\mathrm{SO}_{4}$ type water are perforated in the Quaternary older alluvium and Tertiary younger sedimentary deposits (fig. 3) and have TDS concentrations ranging from 410 to $644 \mathrm{mg} / \mathrm{L}$ (fig. 8). The sample from Garlic Spring (13N/3E-11NS1), north of the basin, is also a $\mathrm{NaHCO}_{3}-\mathrm{SO}_{4}$ type water (figs. 8 and $9 \mathrm{~A}$ ). Well $13 \mathrm{~N} / 3 \mathrm{E}-24 \mathrm{~N} 1$ is perforated in the Quaternary playa deposits beneath Langford Well Lake (dry) playa, and the well yields a sodium-chloride $(\mathrm{NaCl})$ type water with a TDS concentration of $3,220 \mathrm{mg} / \mathrm{L}$ - the highest concentration in the basin (figs. 3C, 8, and $9 A$ ). Well 13N/3E-26K2 is perforated in the Tertiary older sedimentary deposits in the central part of the basin, and the well yields a sodium-sulfate $\left(\mathrm{NaSO}_{4}\right)$ type water with a TDS concentration of $596 \mathrm{mg} / \mathrm{L}$ (figs. $3 B, 8$, and $9 B$ ). The chemistry of well $13 \mathrm{~N} / 3 \mathrm{E}-35 \mathrm{~A} 1$ and changes over time are discussed later in this section. 


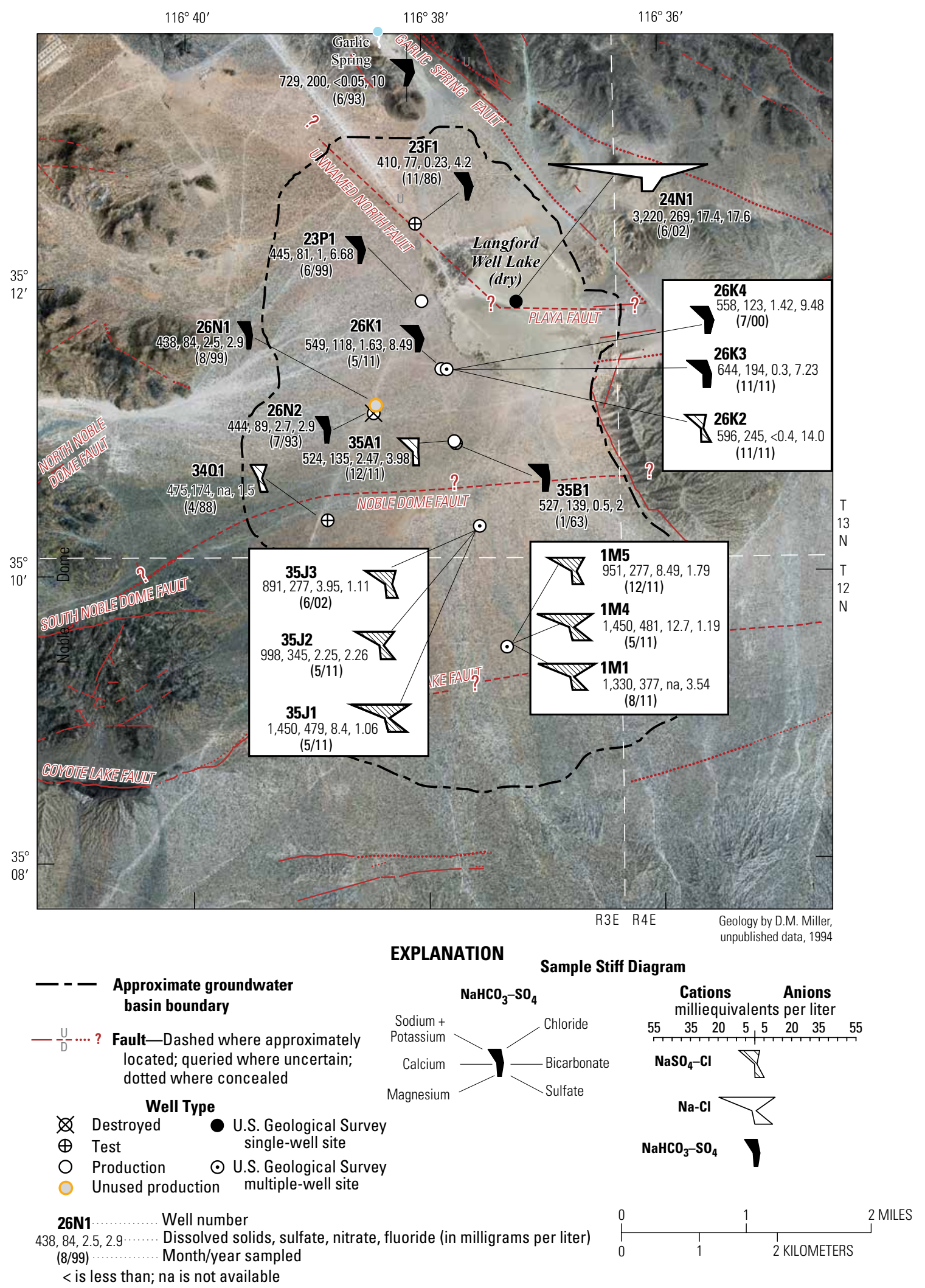

Figure 8. Stiff diagrams, and concentrations of dissolved solids, sulfate, nitrate, and fluoride in groundwater from selected wells in Langford Basin, Fort Irwin National Training Center, California. 
$A$ Langford wells and Garlic Spring

Northern part of basin

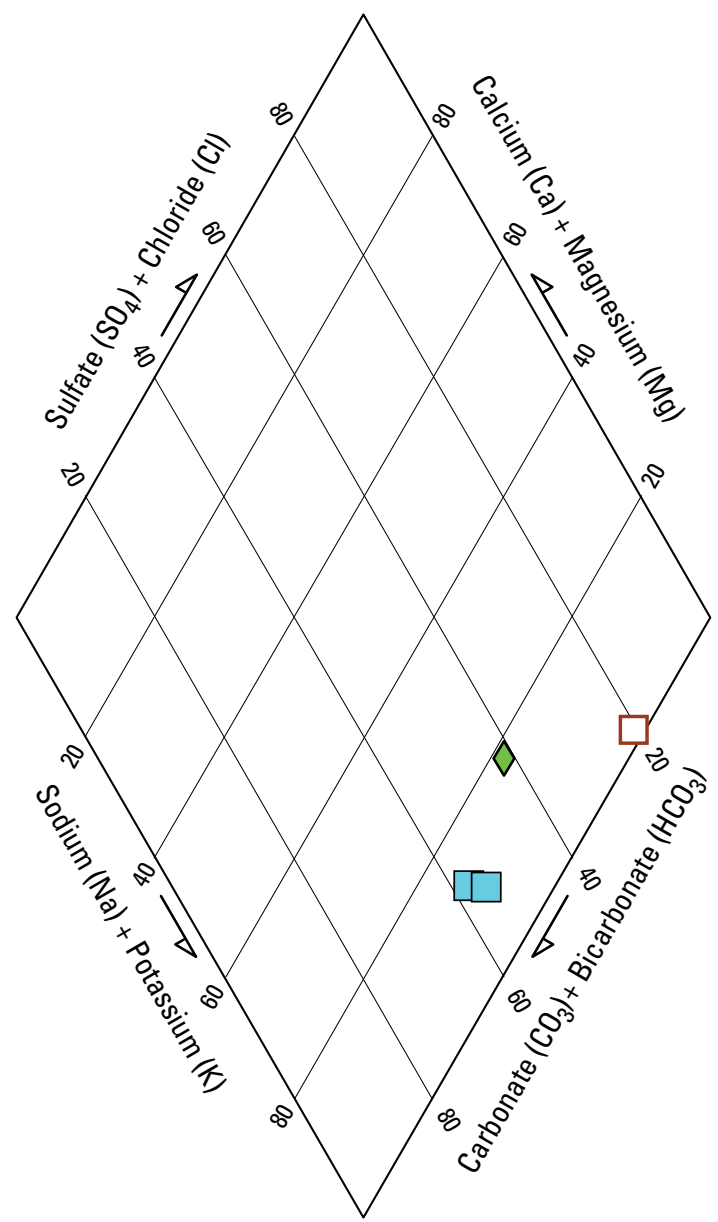

Percent of total milliequivalents per liter

EXPLANATION

Collected 1955-93

13N/3E-23F1 (Ooa, Tyg, and Tog)

Collected after 1993

$\diamond 13 N / 3 E-11 N S 1$ Garlic Spring

13N/3E-24N1 (Qp)
B

Langford wells

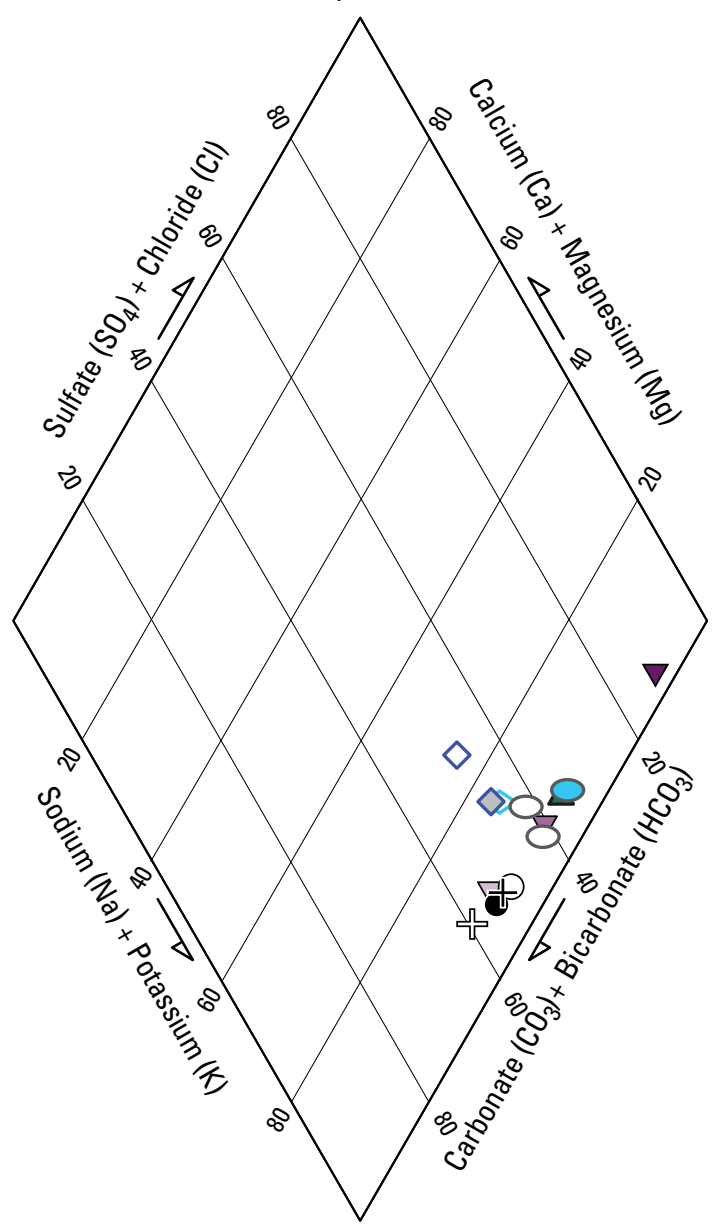

Percent of total milliequivalents per liter

EXPLANATION

Collected 1955-93

13N/3E-23P1 (0oa and Tyg)

ك 13N/3E-26K1 (Ooa and Tyg)

$\diamond$ 13N/3E-26N1 (0oa)

$\diamond$ 13N/3E-26N2 (0oa)

13N/3E-35A1 (0oa and Tyg)

$\triangle$ 13N/3E-35B1 (Qoa and Tyg)

Collected after 1993

Location of wells shown on figure 2
13N/3E-23P1 (0oa and Tyg)

$+13 \mathrm{~N} / 3 \mathrm{E}-26 \mathrm{~K} 1$ (Qoa and Tyg)

$\nabla$ 13N/3E-26K2 LL1 at 780 feet (Tog)

$\nabla$ 13N/3E-26K3 LL1 at 420 feet (Tyg)

$\nabla$ 13N/3E-26K4 LL1 at 210 feet (Qoa)

$\diamond 13 \mathrm{~N} / 3 \mathrm{E}-26 \mathrm{~N} 1$ (Ooa)

13N/3E-35A1 (0oa and Tyg)

Figure 9. Trilinear diagrams of groundwater from selected wells in $A$, the northern part; $B$, the central part; and $C$, the southern part of Langford Basin, Fort Irwin National Training Center, California. 


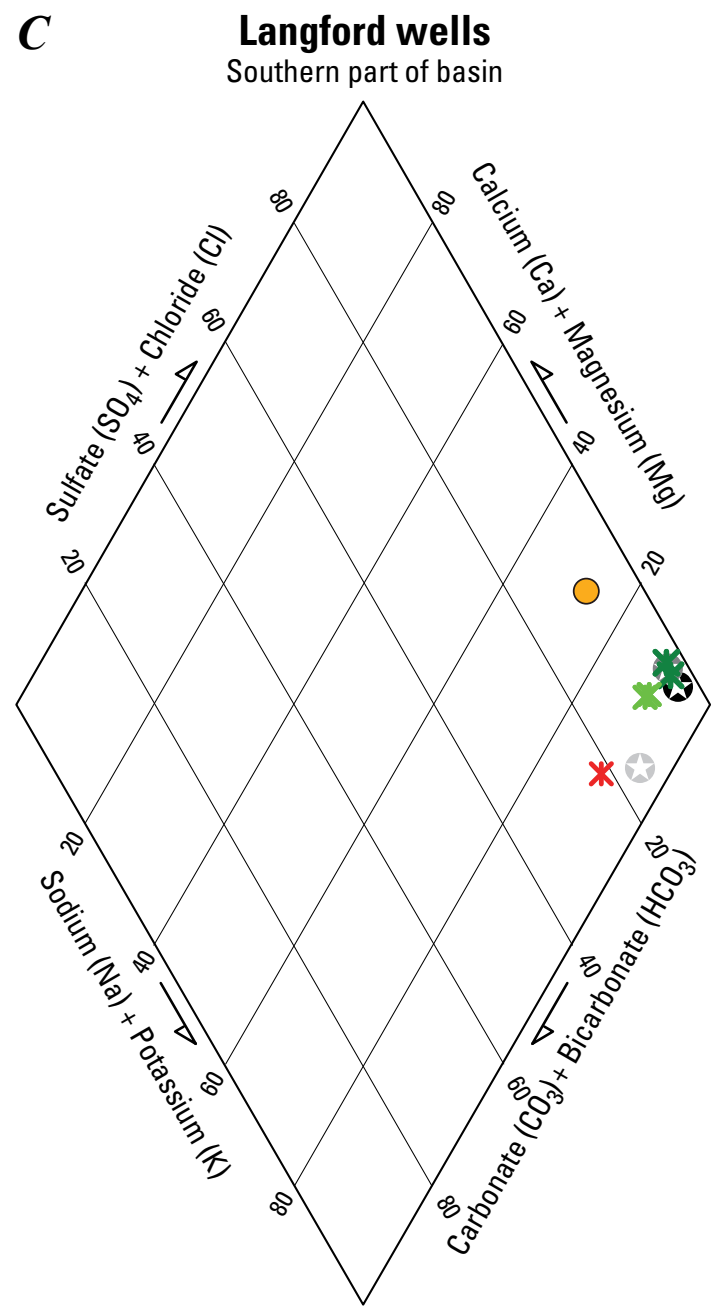

Percent of total milliequivalents per liter

\section{EXPLANATION}

Collected after 1993

13N/3E-3401 (Tyg) 12N/3E-1M1 (Tog)
X 13N/3E-35J1 (Tog) 12 N/3E-1M4 (Tog)
X 13N/3E-35J2 (Tog)
X 13N/3E-35J3 (Tyg)

Figure 9. Trilinear diagrams of groundwater from selected wells in $A$, the northern part; $B$, the central part; and $C$, the southern part of Langford Basin, Fort Irwin National Training Center, California.-Continued

Groundwater samples from wells in the southern part of the basin $(13 \mathrm{~N} / 3 \mathrm{E}-34 \mathrm{Q} 1,13 \mathrm{~N} / 3 \mathrm{E}-35 \mathrm{~J} 1,13 \mathrm{~N} / 3 \mathrm{E}-35 \mathrm{~J} 2,13 \mathrm{~N} / 3 \mathrm{E}-$ $35 \mathrm{~J} 3,12 \mathrm{~N} / 3 \mathrm{E}-1 \mathrm{M} 1,12 \mathrm{~N} / 3 \mathrm{E}-1 \mathrm{M} 4$, and 12N/3E-1M5) are sodium-sulfate-chloride to sodium-chloride-sulfate $\left(\mathrm{NaSO}_{4}-\mathrm{Cl}\right.$ to $\mathrm{NaCl}-\mathrm{SO}_{4}$ ) type waters with TDS concentrations ranging from 475 to $1,450 \mathrm{mg} / \mathrm{L}$ (figs. 8 and $9 C$ ). Wells $13 \mathrm{~N} / 3 \mathrm{E}-34 \mathrm{Q} 1$, $13 \mathrm{~N} / 3 \mathrm{E}-35 \mathrm{~J} 3$, and $12 \mathrm{~N} / 3 \mathrm{E}-1 \mathrm{M} 5$ are perforated in the Tertiary younger sedimentary deposits and wells $13 \mathrm{~N} / 3 \mathrm{E}-35 \mathrm{~J} 2$, $13 \mathrm{~N} / 3 \mathrm{E}-35 \mathrm{~J} 1,12 \mathrm{~N} / 3 \mathrm{E}-1 \mathrm{M} 1$, and $12 \mathrm{~N} / 3 \mathrm{E}-1 \mathrm{M} 4$ are perforated in the Tertiary older sedimentary deposits (fig. 3). The TDS concentrations are higher and the cation-anion proportions more uniform in most wells perforated in the Tertiary older sedimentary deposits than in the Tertiary younger sedimentary deposits (figs. 8 and 9C).

Since groundwater withdrawals began in 1992, water-quality samples from long-screened production well 13N/3E-35A1 have become enriched in $\mathrm{SO}_{4}$ and $\mathrm{Cl}$ and depleted in $\mathrm{HCO}_{3}$, shifting from $\mathrm{NaHCO}_{3}-\mathrm{SO}_{4}$ type water prior to 1993 to $\mathrm{NaSO}_{4}-\mathrm{Cl}$ type water in 1999. During this period, groundwater withdrawals from well 13N/3E-35A1 have caused a groundwater-level depression surrounding the well, which has reversed the direction of groundwater flow north of the well and increased the groundwater-level gradient south of the well (fig. 7). Groundwater withdrawals also have created an upward hydraulic gradient between the lower (Tertiary older sedimentary deposits) and middle (Tertiary younger sedimentary) aquifers in the central part of the basin (appendix fig. A1-1). The change in water type in well $13 \mathrm{~N} / 3 \mathrm{E}-35 \mathrm{~A} 1$ could be the result of groundwater withdrawals from the well, causing groundwater with enriched concentrations of chloride and sulfate to migrate from (1) the Quaternary playa deposits beneath Langford Well Lake (dry) playa, about $1 \mathrm{mi}$ to the northeast; or (2) the Tertiary older sedimentary deposits that underlie the central part of the basin and are present south of the Noble Dome Fault at the same altitude as the perforated interval of well 13N/3E-35A1, about 2,000 ft south of the well (fig. 3).

The relation between concentrations of chloride and sulfate was used to help determine the source of the increased concentrations of chloride and sulfate observed at well 13N/3E-35A1 (fig. 10). Samples from the central and northern part of the basin with $\mathrm{NaHCO}_{3}-\mathrm{SO}_{4}$ type water (referred to in this report as native groundwater) have low concentrations of chloride and sulfate and plot on the lower left part of the graph (fig. 10). The sample from well 13N/3E-24N1, perforated in the Quaternary playa deposits beneath Langford Well Lake (dry) playa, is a $\mathrm{NaCl}$ type water and plots in the upper part of the graph. Samples from wells 12N/3E-1M1, $12 \mathrm{~N} / 3 \mathrm{E}-1 \mathrm{M} 4,13 \mathrm{~N} / 3 \mathrm{E}-35 \mathrm{~J} 1$, and 13N/3E-35J2, perforated in the Tertiary older sedimentary deposits in the southern part of the basin and well 13N/3E-26K2, perforated in the Tertiary older sedimentary deposits in the central part of the basin are all $\mathrm{NaSO}_{4}-\mathrm{Cl}$ type water and plot along the lower right part of the graph. Mixing lines were plotted between native groundwater and $\mathrm{NaCl}$ type water sampled from well $13 \mathrm{~N} / 3 \mathrm{E}-24 \mathrm{~N} 1$ and $\mathrm{NaSO}_{4}-\mathrm{Cl}$ type water sampled from well 12N/3E-1M4 (fig. 10). Groundwater sampled from well $13 \mathrm{~N} / 3 \mathrm{E}-35 \mathrm{~A} 1$ in 1999 falls on the mixing line between native groundwater and well $12 \mathrm{~N} / 3 \mathrm{E}-1 \mathrm{M} 4$ in the southern part of the basin, indicating the change in quality in well $13 \mathrm{~N} / 3 \mathrm{E}-35 \mathrm{~A} 1$ is the result of mixing with a $\mathrm{NaSO}_{4}-\mathrm{Cl}$ type water from the Tertiary older sedimentary deposits that underlie and lie to the south of the well rather than mixing with the $\mathrm{NaCl}$ type water present in the playa deposits in the northeastern part of the basin (fig. 10). Fluoride concentrations in samples from well $13 \mathrm{~N} / 3 \mathrm{E}-35 \mathrm{~J} 1$ were lower and $\mathrm{NO}_{3}-\mathrm{N}$ concentrations 


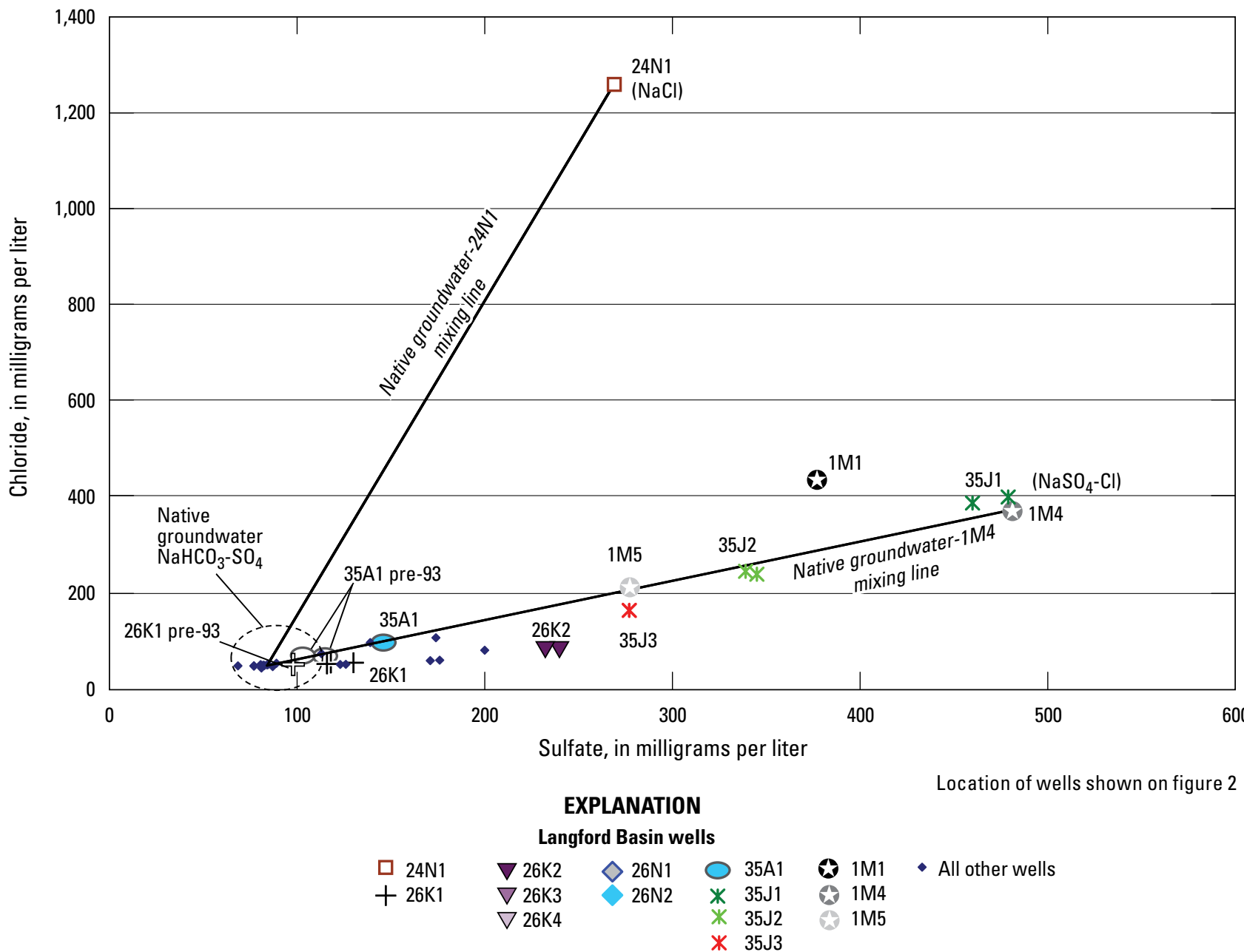

Figure 10. Relation between concentrations of chloride and sulfate in groundwater samples from wells in Langford Basin, Fort Irwin National Training Center, California.

were higher than in the samples from well $13 \mathrm{~N} / 3 \mathrm{E}-35 \mathrm{~A} 1$, but fluoride concentrations in the samples from well $13 \mathrm{~N} / 3 \mathrm{E}-$ $26 \mathrm{~K} 2$ were higher and $\mathrm{NO}_{3}-\mathrm{N}$ concentrations were lower than in the samples from well 13N/3E-35A1 (fig. 8; appendix 2). The observed reduction in fluoride concentration and increase in $\mathrm{NO}_{3}-\mathrm{N}$ concentration in samples from well $13 \mathrm{~N} / 3 \mathrm{E}-35 \mathrm{~A} 1$ imply that mixing of water from this well with water from the Tertiary older deposits in the southern part of the basin is the major source of water contributing to the change in water quality in samples from the well. Depth-dependent water-quality data are needed from well 13N/3E-35A1 and (or) a nearby multiple-well monitoring site to more definitively determine the source of the change in water quality observed in samples from the well.

\section{Specific Constituents of Interest}

TDS, sulfate $\left(\mathrm{SO}_{4}\right)$, nitrate $\left(\mathrm{NO}_{3}\right)$, and fluoride $(\mathrm{F})$ are of interest in the Langford Basin because concentrations of these constituents in samples from some wells exceed State or Federal recommended or mandatory regulatory standards for drinking water. The concentrations of these constituents are presented in appendix 2, and their areal distribution for selected samples is presented on figure 8 .

TDS concentrations in the samples ranged from 394 to $3,220 \mathrm{mg} / \mathrm{L}$ (fig. 8; appendix 2). Samples from Garlic Spring and 14 of the 18 wells sampled contained TDS concentrations in excess of the U.S. Environmental Protection Agency (USEPA) Secondary Maximum Contaminant Level (SMCL) of $500 \mathrm{mg} / \mathrm{L}$ for TDS (U.S. Environmental Protection Agency, 2002). SMCLs were established only as guidelines to assist public water systems in managing their drinking water for aesthetic considerations, such as taste, color, and odor. These contaminants are not considered to present a risk to human health at the SMCL. The highest TDS concentration was in a sample from well 13N/3E-24N1, on the Langford Well Lake (dry) playa (fig. 8). With the exception of the sample from well 13N/3E-24N1, the TDS concentrations in samples collected from wells north of the Noble Dome Fault were less than $650 \mathrm{mg} / \mathrm{L}$. TDS concentrations in samples from wells 
south of the Noble Dome Fault were higher than samples collected north of the fault. All concentrations exceeded $890 \mathrm{mg} / \mathrm{L}$ except the concentration in the sample from well 13N/3E-34Q1, which had a concentration of $475 \mathrm{mg} / \mathrm{L}$ (fig. 8).

$\mathrm{SO}_{4}$ concentrations in the samples ranged from 77 to $481 \mathrm{mg} / \mathrm{L}$ (fig. 8; appendix 2). Samples from 7 of the 18 wells sampled contained $\mathrm{SO}_{4}$ concentrations in excess of the SMCL of $250 \mathrm{mg} / \mathrm{L}$ for $\mathrm{SO}_{4}$ (U.S. Environmental Protection Agency, 2002). The highest concentration was in a sample from well $12 \mathrm{~N} / 3 \mathrm{E}-1 \mathrm{M} 4$, which is perforated in Tertiary older sedimentary deposits south of the Noble Dome Fault (figs. $3 B$ and 8). In general, samples from wells perforated in the Tertiary older sedimentary deposits and the playa deposits have $\mathrm{SO}_{4}$ concentrations in excess of the SMCL of $250 \mathrm{mg} / \mathrm{L}$ (fig. 3).

$\mathrm{NO}_{3}$ concentrations in samples, measured as $\mathrm{NO}_{3}$ plus nitrite $\left(\mathrm{NO}_{2}\right)$, ranged from 0.23 to $17.4 \mathrm{mg} / \mathrm{L}$ as nitrogen (N) (fig. 8; appendix 2). Because concentrations of $\mathrm{NO}_{2}$ are negligible, $\mathrm{NO}_{2}$ plus $\mathrm{NO}_{3}-\mathrm{N}$ and $\mathrm{NO}_{3}-\mathrm{N}$ are considered equivalent and are referred to in this report as $\mathrm{NO}_{3-\mathrm{N}}$. Samples from 2 of the 18 wells sampled contained concentrations of $\mathrm{NO}_{3}-\mathrm{N}$ in excess of the USEPA Maximum Contaminant Level (MCL) of $10 \mathrm{mg} / \mathrm{L}$ (U.S. Environmental Protection Agency, 2002). MCLs are enforceable standards that were established to protect the public against consumption of drinking-water contaminants that present a risk to human health. An MCL is the maximum allowable amount of a contaminant in drinking water that is delivered to the consumer. The highest concentrations of $\mathrm{NO}_{3}-\mathrm{N}$ were measured in samples from well $13 \mathrm{~N} / 3 \mathrm{E}-$ $24 \mathrm{~N} 1$, perforated in the playa deposits, and well $12 \mathrm{~N} / 3 \mathrm{E}-1 \mathrm{M} 4$, perforated in the Tertiary older sedimentary deposits (figs. 3 and 8). These wells also had high concentrations of TDS. Therefore, the high concentrations of $\mathrm{NO}_{3}-\mathrm{N}$ in samples from this well can be explained, in part, by past evaporative concentration $\mathrm{NO}_{3}$ in shallow groundwater. The source of $\mathrm{NO}_{3}$ in the Langford Basin is probably naturally occurring $\mathrm{N}$ in desert soils. Densmore and Bohlke (2000) measured concentrations as high as 3,374 milligrams per kilogram along the eastern edge of the Bicycle Lake in nearby Bicycle Basin, which they attributed to natural soil $\mathrm{NO}_{3}$ on the basis of $\mathrm{N}$ isotope analyses. Additionally, N-bearing rocks and sediments are present in some deposits in the area, primarily the clay/shale units of the nearby Barstow Formation (Noble and Mansfield, 1922; Byers, 1960).

Concentrations of $\mathrm{F}$ in samples collected from wells for this study ranged from 0.91 to $17.6 \mathrm{mg} / \mathrm{L}$ (fig. 8; appendix 2). The highest concentration was from monitor well 13N/3E-24N1, which is in the Langford Well Lake (dry) playa. Concentrations also were generally higher in the northern part of the basin than in the southern part of the basin. Garlic Spring and 8 of the 18 wells sampled for $F$ contained concentrations in excess of the MCL of $4 \mathrm{mg} / \mathrm{L}$ set by the USEPA for F (U.S. Environmental Protection Agency, 2005 (appendix 2). $\mathrm{F}$ is found naturally within many types of rock (Hem, 1992), and its presence in the Langford Basin is from the weathering and dissolution of minerals that contain $\mathrm{F}$ in the basin. Additionally, the concentration of $\mathrm{F}$ in groundwater largely is dependent on the reaction time with aquifer materials. High concentrations of $\mathrm{F}$ can be built up in groundwater that has a long residence time (Brunt and others, 2004).

\section{Trace Elements}

Trace elements are generally present in small concentrations in natural water systems. Although trace elements are essential nutrients, certain trace elements such as arsenic (As), chromium, and uranium are common environmental contaminants and are known to be toxic in drinking water. Their presence in groundwater and surface water can be due to natural sources, such as dissolution of naturally occurring minerals containing trace elements in the geologic deposits, or due to human activities such as mining, burning of fossil fuels, and improper disposal of industrial wastes. Of the trace elements analyzed for this study, only concentrations of As exceeded the USEPA MCLs (appendix 2).

Concentrations of As in samples collected from wells for this study ranged from 2.4 to $39.4 \mu \mathrm{g} / \mathrm{L}$ (appendix 2). Garlic Spring and 5 of the 17 wells sampled for As contained concentrations in excess of the MCL of $10 \mu \mathrm{g} / \mathrm{L}$ set by the USEPA for As (U.S. Environmental Protection Agency, 2005) (appendix 2). None of the water samples from the production wells exceeded the MCL for As. Similar to F, the highest concentration of As was from monitor well 13N/3E-24N1, which is in the Langford Well Lake (dry) playa. The high concentrations of As in samples from this well may be explained by past evaporative concentrations of As in shallow groundwater. As previously described, the sample from well $13 \mathrm{~N} / 3 \mathrm{E}-24 \mathrm{~N} 1$ also contained the highest concentrations of TDS and $\mathrm{NO}_{3}$. As does not appear to partition into evaporite minerals until a very high salinity is attained, which can result in concentrations of As in excess of $100 \mathrm{mg} / \mathrm{L}(100,000 \mu \mathrm{g} / \mathrm{L})$ in shallow groundwater affected by evaporative processes at discharge areas (Levy and others, 1999).

Concentrations of As exceeded $25 \mu \mathrm{g} / \mathrm{L}$ in samples from monitor wells 12N/3E-1M5 and 13N/3E-35J3, relatively shallow wells south of the Noble Dome Fault (appendix 2). Samples from both wells were collected near the top of the water table and had $\mathrm{pH}$ values greater than 8 (alkaline) and dissolved-oxygen concentrations in excess of $1.9 \mathrm{mg} / \mathrm{L}$ (oxic conditions) (appendix 2). Although the reactions take place slowly, weathering of primary silicate minerals in aquifer materials derived from relatively nonreactive granitic or metamorphic rocks may increase groundwater $\mathrm{pH}$ (Nishikawa and others, 2005). As pH increases to values greater than 8 , As sorbed on mineral grains may come into solution in oxic aquifers (Welch and others, 2000; Nishikawa and others, 2005). This mechanism has been cited as the cause of concentrations of As exceeding MCLs in other alluvial aquifers in the western United States (Welch and others, 2000; Nishikawa and others, 2005). Concentrations may also be affected by high concentrations of As from the Tertiary deposits as was observed in the sample from 13N/3E-26K2. 


\section{Source and Age of Groundwater}

Samples were analyzed for the stable isotopes of oxygen $\left({ }^{18} \mathrm{O}\right)$ and hydrogen $\left({ }^{2} \mathrm{H}\right.$, or deuterium, D) to determine the source of water to wells and to evaluate the movement of water through the study area. Selected samples were analyzed for the radioactive isotopes of hydrogen (tritium, ${ }^{3} \mathrm{H}$ ), and carbon $\left({ }^{14} \mathrm{C}\right)$ to determine the age, or time since recharge, of the groundwater. A total of 24 water samples were collected from 2 multiple-well monitoring sites, 1 single-well monitoring site, 5 existing wells, and 1 spring (appendix 2).

\section{Stable Isotopes of Oxygen and Hydrogen}

Oxygen-18 and deuterium are natural stable isotopes of oxygen and hydrogen, respectively, that were used in this study to help identify the source and hydrologic history of groundwater in the Langford Basin. These isotopic ratios are expressed in delta notation $(\delta)$ as per mil (parts per thousand or \%o) differences, relative to the standard known as Vienna Standard Mean Ocean Water (VSMOW) (Gonfiantini, 1978). The linear relation between $\delta^{18} \mathrm{O}$ and $\delta \mathrm{D}$ in natural precipitation throughout the world (Craig, 1961) is referred to as the Global Meteoric Water Line (fig. 11). Differences in the isotopic composition of precipitation take place along this line in response to trends with latitude and with the temperature of condensation (Fournier and Thompson, 1980). More negative values (depletion in the heavier isotope relative to the lighter isotope) result when condensation takes place at colder temperatures and higher altitudes. Water that has been partly evaporated is enriched in heavier isotopes relative to its original composition; these values plot to the right of the meteoric water line (for $\delta \mathrm{D}$ as the vertical axis and $\delta^{18} \mathrm{O}$ as the horizontal axis). There is no further change in isotopic composition at the low temperatures of most groundwater systems after recharged water has migrated below the depth of evaporation. Therefore, any subsequent differences in the isotopic composition of groundwater along a flow line generally reflect only mixing within the aquifer system or concentration by evaporation in a discharge area. The $\delta^{18} \mathrm{O}$ and $\delta \mathrm{D}$ composition of groundwater, relative to the meteoric water line, and the isotopic composition of water from other sources can be an indicator of the source of groundwater.

The isotopic compositions of groundwater from wells in the Langford Basin ranged from -10.44 to $-12.39 \% \delta^{18} \mathrm{O}$ and -89.7 to $-97.6 \% \delta \mathrm{D}$ (fig. 11 ; appendix 2). The isotope values from all samples collected from Langford Basin fall below the Global Meteoric Water Line, indicating possible evaporation at land surface prior to recharge, partial evaporation of falling raindrops in an arid atmosphere, or a "local" meteoric water line that differs slightly from the Global Meteoric Water Line. Volume-weighted samples of local precipitation at Daggett (Friedman and others, 1992), near Barstow and at about 2,000 $\mathrm{ft}$ altitude (similar to Langford Basin), also fall below the Global Meteoric Water Line but are isotopically heavier than groundwater samples from Langford Basin (fig. 11). Isotope values from groundwater samples in Indian Wells Valley, west of this study area and not shown on figure 1, also plot along a line that is nearly parallel to and below the Meteoric Water Line (Berenbrock and Schroeder, 1994), suggesting the isotopic values in the area fall along a local Global Meteoric Water Line that is about 5 to $10 \%$ (on the $\delta \mathrm{D}$ axis) below the Global Meteoric Water Line (fig. 11).

The isotope values from the Langford Basin plot near samples unaffected by evaporation in the Irwin Basin, indicating the source of recharge to these basins was similar. Groundwater from wells near the wastewater-treatment facility and the base housing in the Irwin Basin has been evaporated and lies on the evaporative line (Densmore and Londquist, 1997). These groundwater samples are isotopically heavier than water from other wells in the Irwin and Langford Basins (fig. 11). Groundwater from wells 13N/3E-35J1, 13N/3E-35J2, $13 \mathrm{~N} / 3 \mathrm{E}-35 \mathrm{~J} 3,12 \mathrm{~N} / 3 \mathrm{E}-1 \mathrm{M} 1$, and $12 \mathrm{~N} / 3 \mathrm{E}-1 \mathrm{M} 4$ in the southern part of the Langford Basin plot below and slightly to the right relative to water from the other wells in the northern and western parts of Langford Basin, indicating groundwater from these wells was recharged from a slightly different source or was evaporated prior to recharge. Recharge to this part of the basin most likely was from storms and surface runoff from storms that originated from the Alvord Mountain area, to the south of the study area (fig. 1). Because the $\delta \mathrm{D}$ of water samples in the Langford Basin is more than $20 \%$ lighter (more negative) than local winter precipitation at Daggett (fig. 11), the groundwater probably was not recharged under present-day climatic conditions. In addition to the difference in isotopic concentration, the relative age of the water supports this hypothesis. As described in the "Tritium and Carbon-14" section of this report, recharge to the area dates to near the end of the last North American glaciation (Byers, 1960; Pagnac and Reynolds, 2006) when it likely was colder and (or) wetter in the study area, which would cause isotope ratios to be lighter (more negative) than in postglacial (younger) water.

\section{Tritium and Carbon-14}

Tritium is a natural radioactive isotope of hydrogen that has a half-life of 12.4 years. The concentration of ${ }^{3} \mathrm{H}$ is reported in picocuries per liter $(\mathrm{pCi} / \mathrm{L})$ and tritium units $(\mathrm{TU})$ in the appendix but is discussed in TU in this section. Approximately 800 kilograms of ${ }^{3} \mathrm{H}$ were released into the atmosphere as a result of the atmospheric testing of nuclear weapons between 1952 and 1962 (Michel, 1976). As a result, ${ }^{3} \mathrm{H}$ concentrations in precipitation and groundwater recharge increased during that time. Concentrations of ${ }^{3} \mathrm{H}$ are not affected substantially by chemical reactions other than radioactive decay because ${ }^{3} \mathrm{H}$ is part of the water molecule. Therefore, ${ }^{3} \mathrm{H}$ is an excellent tracer of the movement and relative age of water on timescales ranging from recent to about 60 years before present (post 1952). In this report, groundwater that has measurable ${ }^{3} \mathrm{H}$ concentrations (greater than $0.2 \mathrm{TU}$ ) is interpreted to be water recharged after 1952, or recent recharge. 


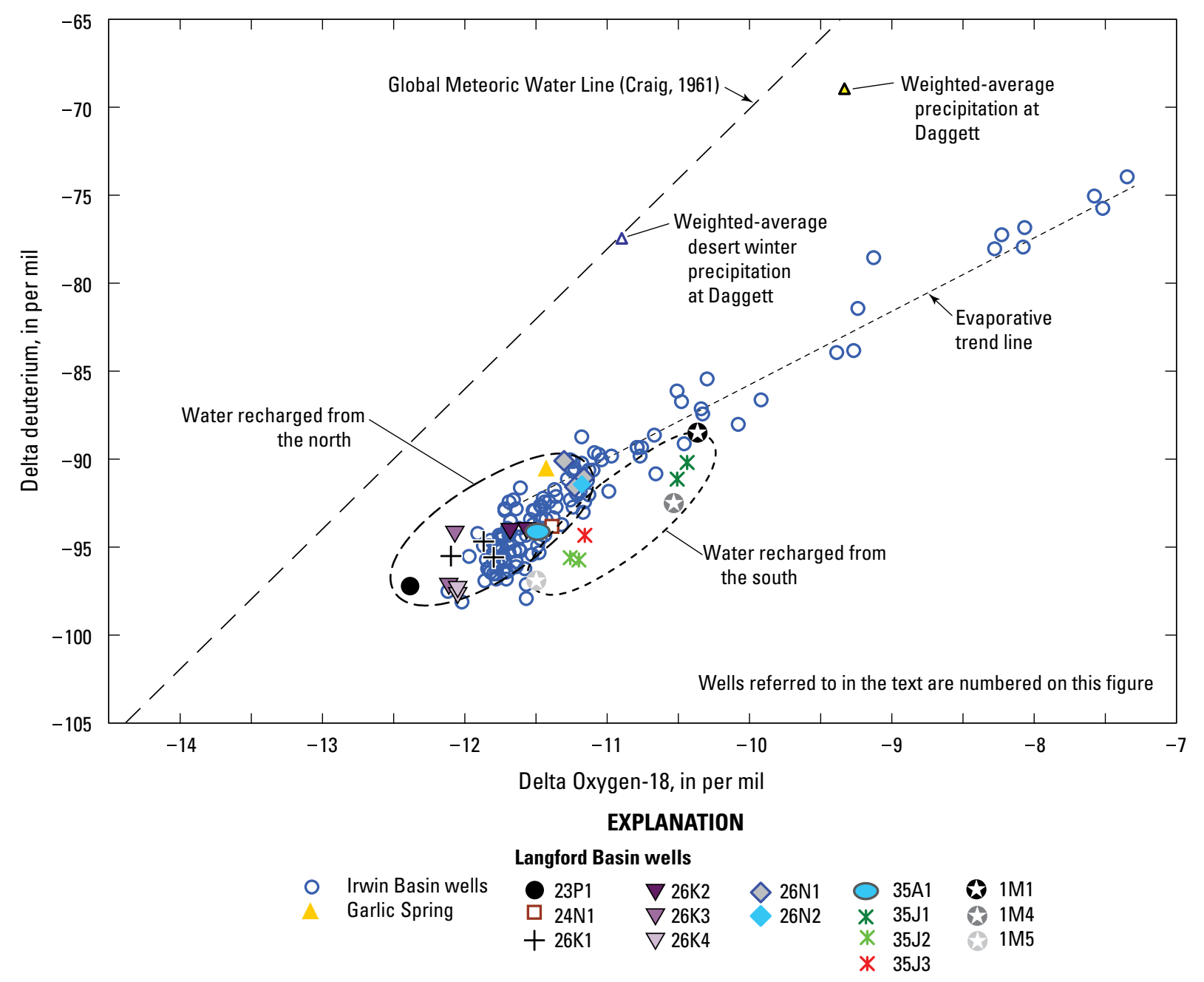

Figure 11. Stable-isotope concentrations in groundwater from selected wells in Langford Basin, Fort Irwin National Training Center, California.

Carbon-14 is a natural radioactive isotope of carbon that has a half-life of about 5,730 years (Mook, 1980). Carbon-14 data are expressed as percent modern carbon (pmc) by comparing ${ }^{14} \mathrm{C}$ activities to the specific activity of National Bureau of Standards oxalic acid: 13.56 disintegrations per minute per gram of carbon in the year 1950 equals 100 pmc (Kalin, 2000). Carbon-14 was produced, as was ${ }^{3} \mathrm{H}$, by the atmospheric testing of nuclear weapons (Mook, 1980). As a result, ${ }^{14} \mathrm{C}$ activities may exceed $100 \mathrm{pmc}$ in areas where groundwater contains ${ }^{3} \mathrm{H}$. Carbon-14 activities are used to determine the age of a groundwater sample on timescales ranging from recent to more than 20,000 years before present. Carbon-14 is not part of the water molecule and, therefore, ${ }^{14} \mathrm{C}$ activities may be affected by chemical reactions that remove or add carbon to the water. In addition, ${ }^{14} \mathrm{C}$ activities are affected by mixing younger water that has high ${ }^{14} \mathrm{C}$ activity with older water that has low ${ }^{14} \mathrm{C}$ activity. In this discussion, young water is considered to be recent water as described above. Carbon-14 ages presented in this report do not account for changes in ${ }^{14} \mathrm{C}$ activity resulting from chemical reactions or mixing and, therefore, are considered uncorrected ages. In general, uncorrected ${ }^{14} \mathrm{C}$ ages are older than the actual age of the associated water. Izbicki and others (1995) estimated that uncorrected ${ }^{14} \mathrm{C}$ ages were as much as 30 percent older than the actual ages of groundwater in the regional aquifer in the Mojave River groundwater basin near Victorville, California (not shown), about $60 \mathrm{mi}$ southwest of the study area.

No measurable concentrations of ${ }^{3} \mathrm{H}$ were present in groundwater samples from 11 wells in Langford Basin (fig. 12). The lack of ${ }^{3} \mathrm{H}$ in samples from Langford Basin indicates the groundwater was recharged prior to 1952 . Measured ${ }^{14} \mathrm{C}$ activities for water from six wells in Langford Basin ranged from 2.6 to 21.9 pmc (fig. 12). It should be noted that the sample from well $12 \mathrm{~N} / 3 \mathrm{E}-1 \mathrm{M} 1$, a deep well perforated in fine-grained sediment, had a ${ }^{14} \mathrm{C}$ activity of $53.5 \mathrm{pmc}$ (appendix 2). This well was not thoroughly developed because it has a low hydraulic conductivity and did not produce much water; thus, it is believed that this sample reflects the age of the water mixed with the drilling mud and not the true age of the groundwater from the deep aquifer in which the well 


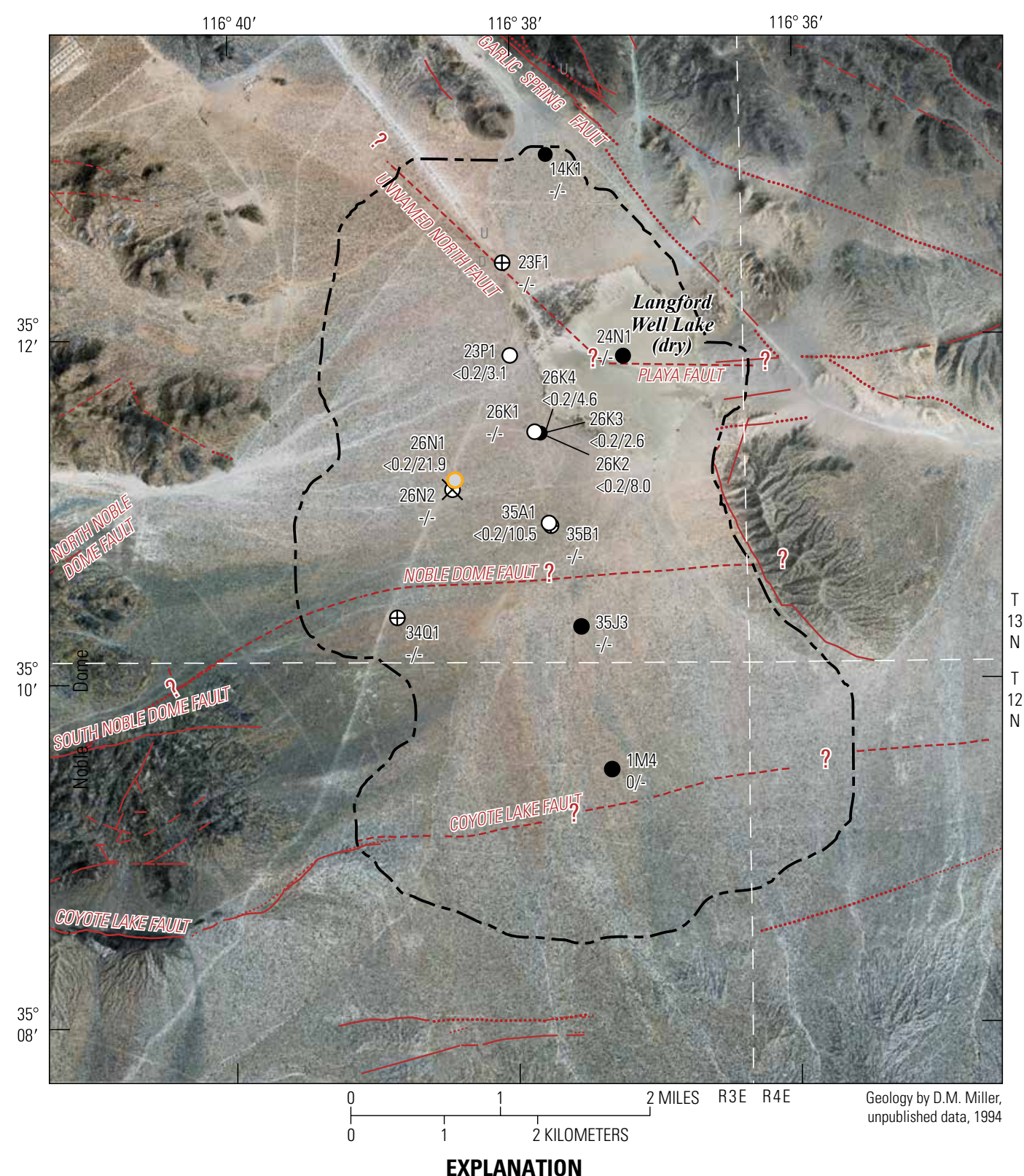

\begin{tabular}{|c|c|c|c|c|}
\hline \multirow{3}{*}{$\begin{array}{l}--- \\
-\frac{U}{D} \cdots \cdot ? ?\end{array}$} & \multirow{3}{*}{$\begin{array}{l}\text { Approximate groundwater } \\
\text { basin boundary } \\
\text { Fault-Dashed where approximately } \\
\text { located; queried where uncertain; } \\
\text { dotted where concealed }\end{array}$} & \multicolumn{3}{|c|}{$\begin{array}{l}\text { Well and number-First number is tritium, in tritium units; } \\
\text { second number is the carbon- } 14 \text { activity, in percent } \\
\text { modern carbon; }--- \text { - indicates no data; < is less than }\end{array}$} \\
\hline & & ${ }_{-/-}^{26 N 2} \not$ Destroyed & $\begin{array}{r}23 \mathrm{P} 1 \\
<0.2 / 5.07\end{array}$ & Production \\
\hline & & 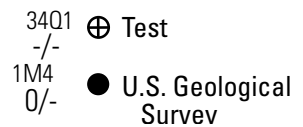 & $\begin{array}{c}26 \mathrm{~N} 1 \\
<0.2 / 21.94\end{array}$ & Unused production \\
\hline
\end{tabular}

Figure 12. Tritium and carbon-14 activities in groundwater from selected wells in Langford Basin, Fort Irwin National Training Center, California. 
is perforated. Further development is needed for this well in order to obtain ${ }^{14} \mathrm{C}$ data representative of natural aquifer conditions. The highest ${ }^{14} \mathrm{C}$ activity $(21.9 \mathrm{pmc})$ from samples considered representative of natural aquifer conditions, was present in well 13N/3E-26N1 along the western edge of the basin near the Noble Dome area. The uncorrected ${ }^{14} \mathrm{C}$ data indicate groundwater in this well has an apparent age of about 12,500 years. Lower ${ }^{14} \mathrm{C}$ activities (less than $11 \mathrm{pmc}$ ) were present in wells near the center of the basin and were farther from areas of recharge. The uncorrected ${ }^{14} \mathrm{C}$ data indicate the groundwater in these wells has an apparent age of 12,500 to 30,300 years. The low ${ }^{14} \mathrm{C}$ activities and the lack of measurable ${ }^{3} \mathrm{H}$ indicate Langford Basin does not receive appreciable amounts of recent recharge and was recharged during or near the end of the last North American glaciation, when it likely was colder and (or) wetter in the study area (Flint, 1971).

\section{Simulation of Groundwater Flow}

A numerical groundwater-flow model was developed for the Langford Basin to better understand the aquifer system, used by the Fort Irwin NTC as part of its water supply, and to provide a tool to help manage groundwater resources at the Fort Irwin NTC. A three-dimensional groundwater-flow model of the aquifer system within the Langford Basin was developed by creating a mathematical representation of the hydrogeologic framework and flow system. The USGS modular finite-difference groundwater-flow model, MODFLOW-2005 (Harbaugh, 2005), was used in this study The MODFLOW code consists of a main program and a series of independent subroutines called modules. The MODFLOW modules used in this study included Basic (BAS6), Discretization (DIS), Layer Property Flow (LPF), Recharge (RCH), Multi-Node Well (MNW2) (Konikow and others, 2009), Drain (DRN), Horizontal Flow Boundary (HFB6), and Zone (ZONE). The model uses the Geometric Multigrid Solver (GMG) (Wilson and Naff, 2004).

\section{Model Discretization}

The study area was discretized horizontally into a constantspaced model grid. The origin of the model grid (the upper left corner of the grid), located at 2,373,237 ft north and 669,380 ft east in zone 5 of the California State Plane Coordinate System, was placed about $4 \mathrm{mi}$ north and $2.5 \mathrm{mi}$ west of the boundary of Irwin Basin (fig. 13). A model grid, consisting of 152 rows and 125 columns of square cells with side lengths of $500 \mathrm{ft}$, was defined initially in a companion report describing the groundwater-flow model for the Irwin Basin (Densmore, 2003). The model grid covers the Irwin, Bicycle, and Langford Basins. Rows 73-152 and columns 46-105 of the larger model grid were used to simulate the area in the Langford Basin. For the purposes of this report, the active grid was reduced to
80 rows and 60 columns (rows 73-152 and columns 46-105 of the large grid) (fig. 13). The origin for the Langford Basin model is the point at 2,395,757 ft north and 593,380 ft east in zone 5 of the California State Plane Coordinate System (fig. 13).

The Langford Basin aquifer system was discretized vertically into three layers of varying thickness (fig. 15). Model layer 1 includes the upper-most saturated part of the sediments. Layer 1 consists of the saturated Quaternary deposits (primarily Qoa, Qp) in the center of the basin and extends laterally through Tertiary sediments (Tyg, Tog) on the western and southern margins of the basin. The simulated bottom of layer 1 is the contact between the Quaternary older alluvium, where the Quaternary older alluvium is saturated, and Tertiary younger sedimentary deposits. In order to avoid numeric instabilities resulting from abrupt changes in simulated aquifer thicknesses, in areas where the Quaternary older alluvium is not saturated, the simulated bottom of layer 1 is extended into the saturated Tertiary younger sedimentary or saturated Tertiary older sedimentary deposits. The simulated thickness of layer 1 ranges from $15 \mathrm{ft}$ at the edges of the basin to a maximum of about $240 \mathrm{ft}$.

Model layer 2 includes the middle aquifer, which consists of Tertiary younger sedimentary deposits (Tyg) in the northern half of the basin and extends laterally through Tertiary older sedimentary deposits (Tog) in the southern half of the basin. The simulated bottom of layer 2 is the contact between Tertiary younger sedimentary deposits, where the Tertiary younger sedimentary deposits are saturated, and Tertiary older sedimentary deposits. In areas where the Tertiary younger sedimentary deposits are not saturated, the simulated bottom of layer 2 was extended into saturated Tertiary older sedimentary deposits. Layer 2 ranges in thickness from $14 \mathrm{ft}$ at the edges of the basin to as much as $440 \mathrm{ft}$ near the center of the basin.

Model layer 3 represents the lower aquifer and consists of the Tertiary older sedimentary deposits (Tog). Model layer 3 ranges in thickness from $7 \mathrm{ft}$ at the edges of the basin to $1,120 \mathrm{ft}$ in the area beneath the Langford Well Lake (dry) playa.

The estimated altitudes of the tops and bottoms of the Quaternary older alluvium (Qoa), Tertiary younger sedimentary deposits (Tyg), and Tertiary older sedimentary deposits (Tog) were determined from inspection of geophysical logs, driller's logs, and gravity surveys. The areal extent of layer 1 was determined on the basis of the intersection of the predevelopment water-table altitude and the basement complex. This areal extent represents the boundary of the simulated aquifer system.

The model simulates predevelopment conditions to March 2011. There are 229 stress periods of varying length. The first stress period represents predevelopment conditions and spans $1,000,000$ days. Stress periods 2 through 229 are each 1 month in duration, representing the period from April 1992, when groundwater withdrawals began, to March 2011. 


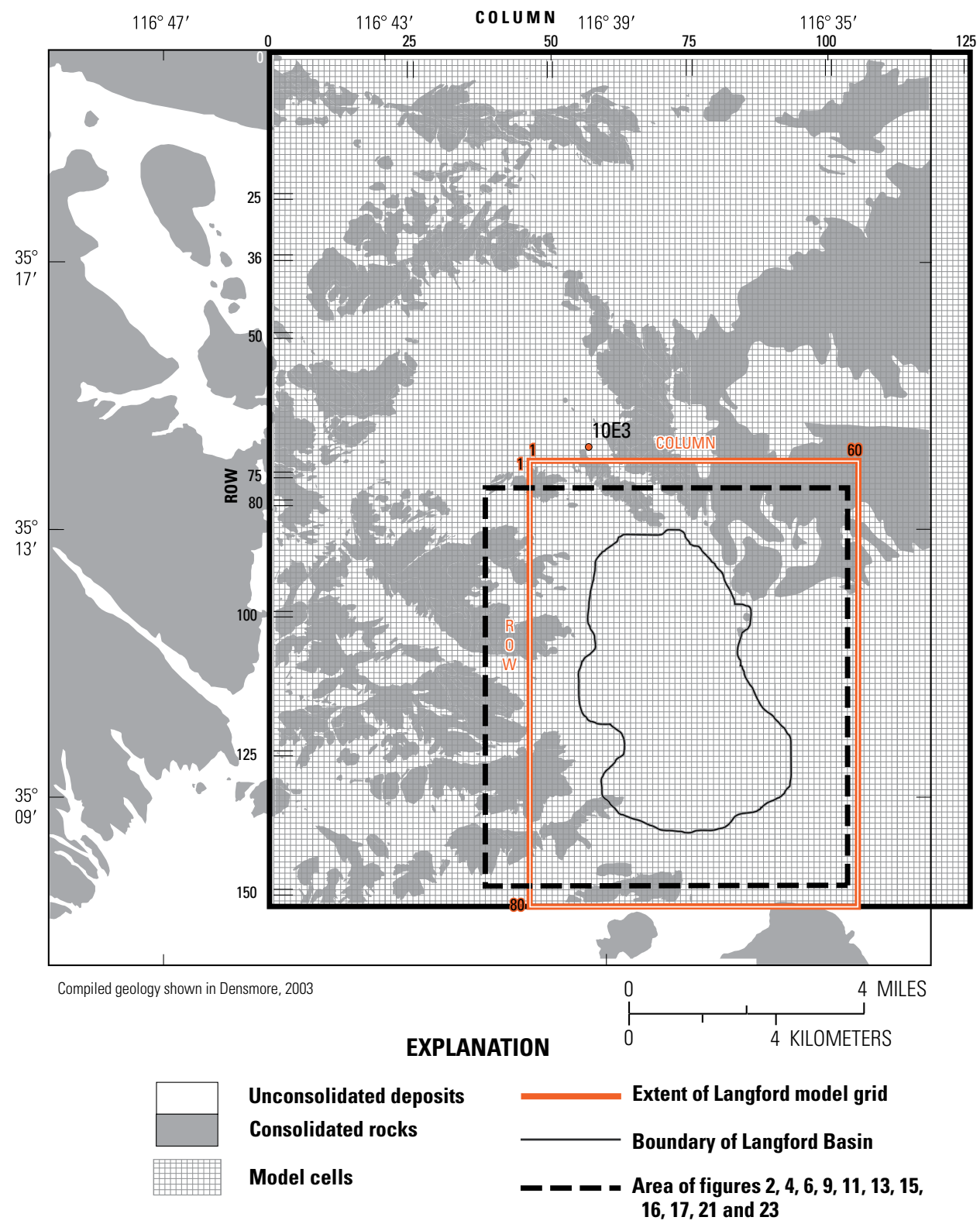

Figure 13. Local model grid of the Langford Basin and the regional mode grid of the Fort Irwin National Training Center, California.

\section{Model Boundaries}

The boundaries of the Langford Basin groundwater-flow model (fig. 14) were determined by geohydrologic interpretations and coincide with the boundary of the aquifer system. The top boundary of the model, the water table, is simulated as a free-surface boundary, which is allowed to move vertically in response to changes in inflow, outflow, and storage of water within the aquifer. No-flow boundaries are used around and below the modeled area to represent contact with the basement complex (fig. 4). The no-flow boundary indicates water is not exchanged between the model cell and the area outside the model.
A drain is used to simulate groundwater discharge in a highly fractured area east of the Langford Well Lake (dry) playa near the buried extension of Garlic Spring Fault (fig. 14). The drain is simulated in the model using the MODFLOW Drain module (Harbaugh, 2005). This module allows groundwater to discharge only when the water level (hydraulic head) in the aquifer is greater than the drain elevation. There is no flow into the drain when the water level in the model cell is less than the elevation of the drain. The elevation of the drain was estimated through model calibration at 2,109 ft above NAVD 88 , but was constrained by land surface and bedrock elevations (fig. $3 C$ ). The drain elevation was estimated 


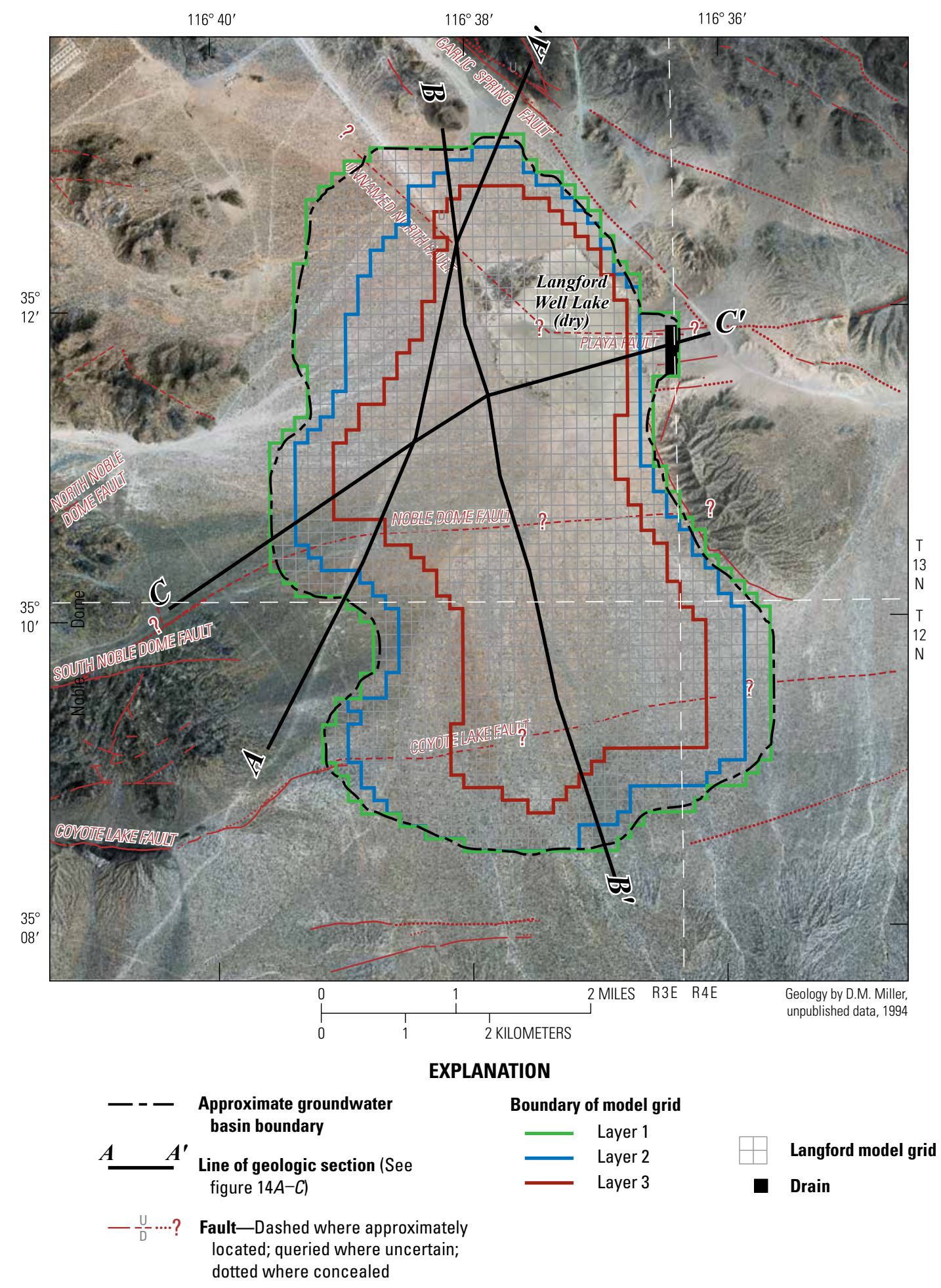

Figure 14. Finite-difference grid and boundary locations, Langford Basin, Fort Irwin National Training Center, California. 


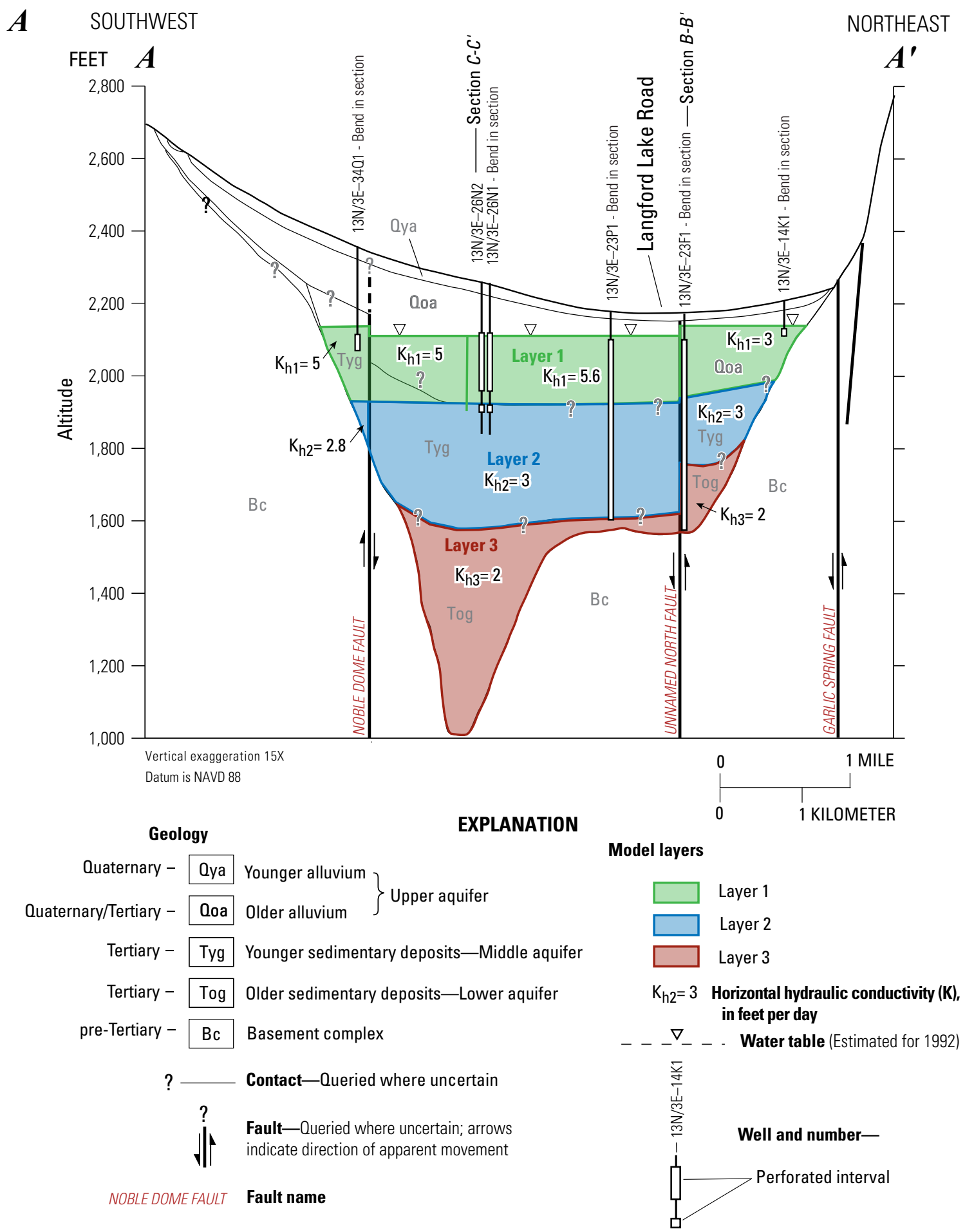

Figure 15. Cross-sectional view $A, A-A^{\prime} ; B, B-B^{\prime} ;$ and $C, C-C^{\prime}$ of model layers and horizontal hydraulic conductivities in the Langford Basin, Fort Irwin National Training Center, California. 

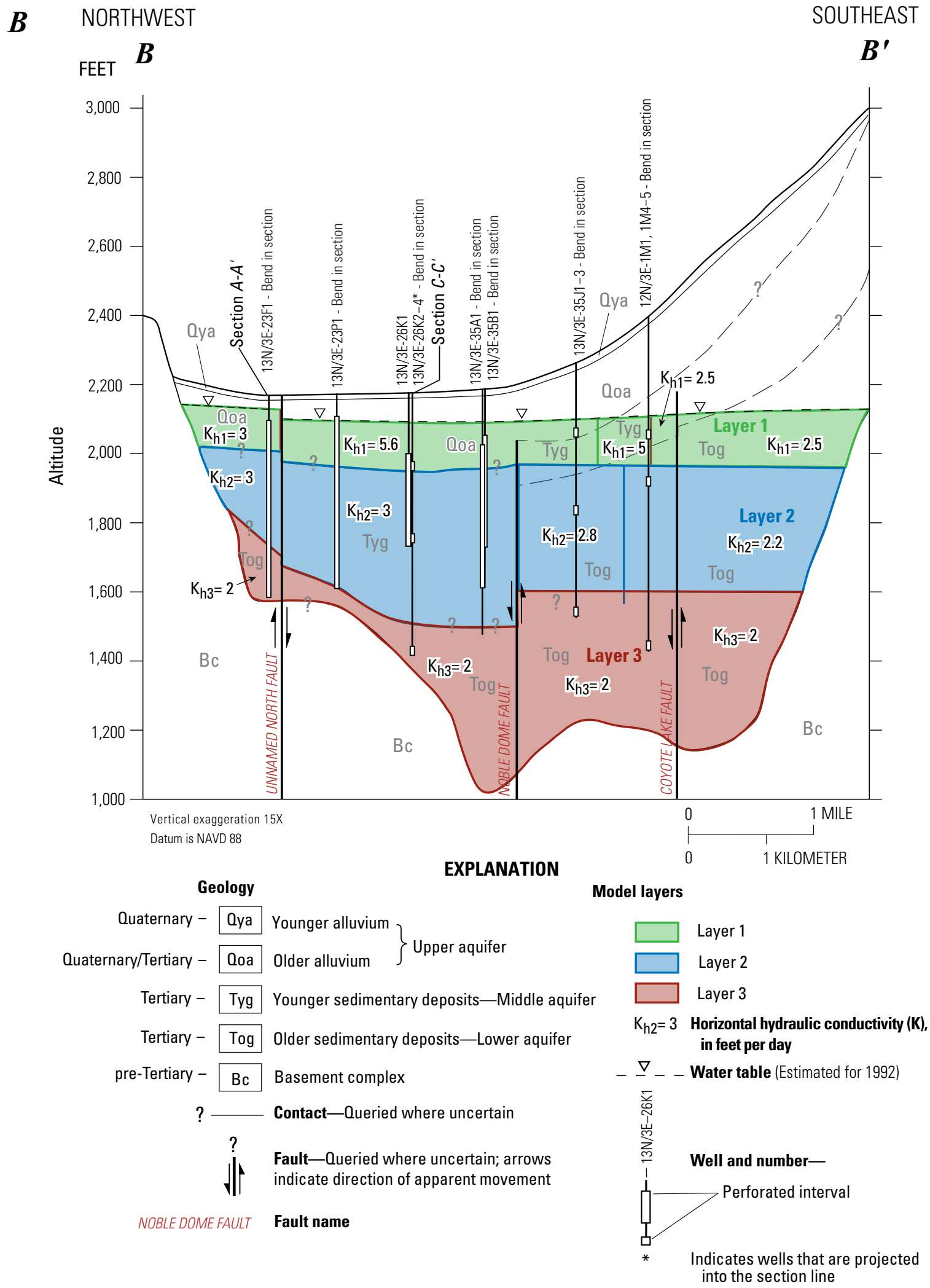

Figure 15. Cross-sectional view $A, A-A^{\prime} ; B, B-B^{\prime} ;$ and $C, C-C^{\prime}$ of model layers and horizontal hydraulic conductivities in the Langford Basin, Fort Irwin National Training Center, California.-Continued 
$\begin{array}{lll}\boldsymbol{C} \text { WEST } & \text { EAST }\end{array}$

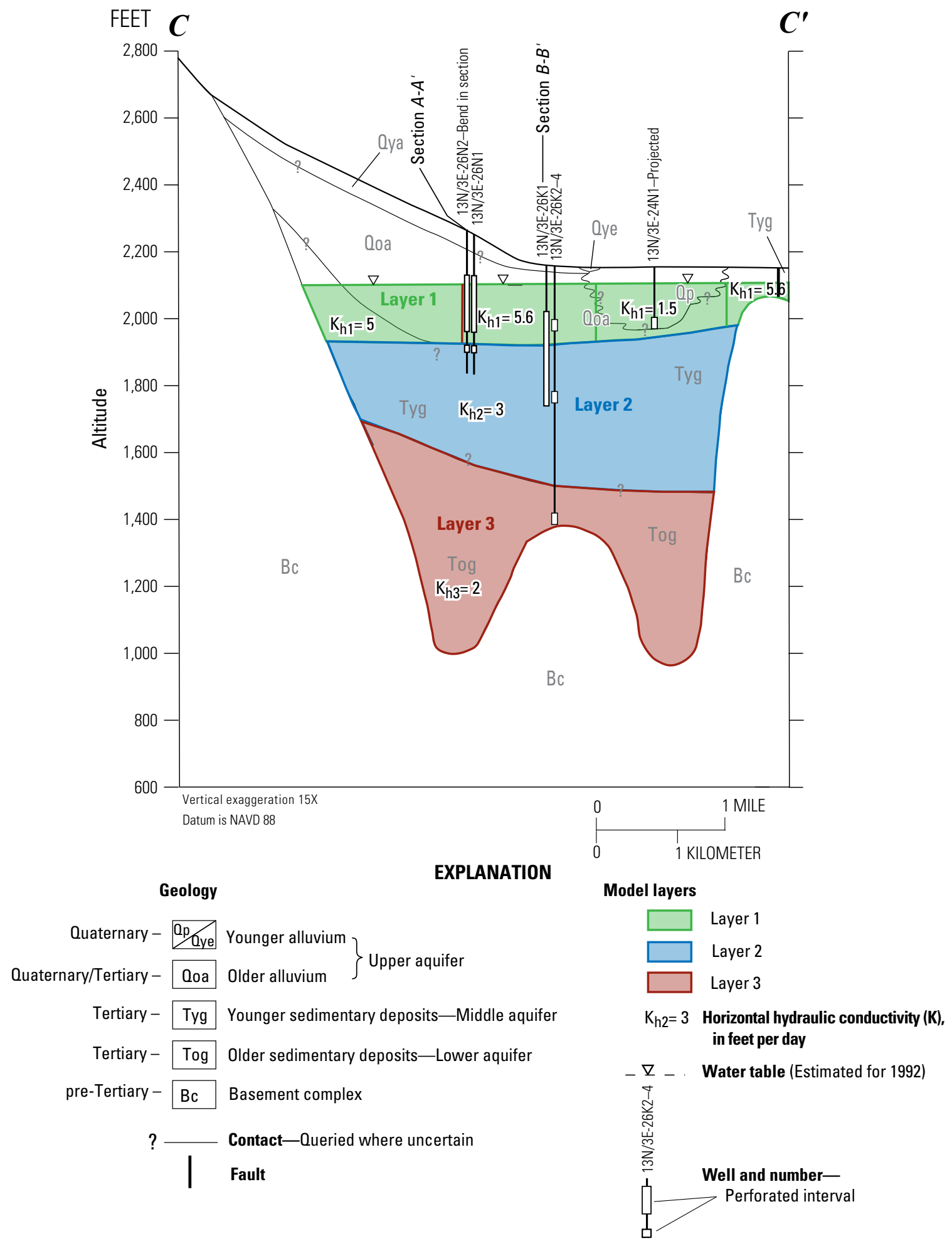

Figure 15. Cross-sectional view $A, A-A^{\prime} ; B, B-B^{\prime} ;$ and $C, C-C^{\prime}$ of model layers and horizontal hydraulic conductivities in the Langford Basin, Fort Irwin National Training Center, California.-Continued 
because there are no wells at this location. Flow out of the drain is controlled by the conductance between the aquifer and the drain and by the effects of the water level (hydraulic head) at each cell. The drain conductance was estimated through model calibration at $15,000 \mathrm{ft}^{2} / \mathrm{d}$.

\section{Model Input}

Model input needed to calibrate a model includes hydraulic properties, recharge, discharge, and withdrawals (table 4). Hydraulic properties include horizontal and vertical hydraulic conductivity for each model layer, specific yield in model layer 1, specific storage in model layers 2 and 3, and the hydraulic characteristic (used to simulate horizontal flow barriers or faults). The hydraulic properties, with the exception of the hydraulic characteristic values, were grouped into zones of similar geologic units that were defined with a single value. Delineation of the zones was based on lithologic logs, the geologic map, and aquifer tests conducted in the Langford Basin. Model layer 1 was divided into five hydraulic property zones, model layer 2 was divided into three zones, and model layer 3 was represented with a single zone (fig. 16). Initial estimates for these properties were determined on the basis of the geologic and hydrologic data compiled from aquifer tests and well-driller's logs. The hydraulic characteristic values were estimated for individual fault segments on the basis of observed water-level differences on opposite sides of the fault segments.

\section{Hydraulic Conductivity}

Estimates of the initial hydraulic conductivities for the unconsolidated deposits, based on aquifer tests and driller's logs for production and monitor wells in Langford Basin, are summarized in table 2 . These estimates served as starting points for the calibration process. Initial hydraulic-conductivity values ranged from 1 to $30 \mathrm{ft} / \mathrm{d}$ and are shown in table $4 B$ for each zone. One horizontal hydraulic-conductivity value was calibrated for each of the hydraulic property zones in each model layer (table $4 B$ ). Final calibrated hydraulic-conductivity values ranged from 1.5 to $5.6 \mathrm{ft} / \mathrm{d}$, and are shown in figure 16 and summarized in table $4 B$.

Table 4. Calibrated parameter values for the calibrated groundwater-flow model, Langford Basin, Fort Irwin National Training Center, California.

[Abbreviations: $\mathrm{ft}$, foot; NAVD 88, North American Vertical Datum of 1988; $\mathrm{ft}^{2} / \mathrm{d}$, foot squared per day; ft/d, foot per day; $\mathrm{ft}^{-1}, 1$ per foot; Qp, Quaternary playa deposits; Qoa, Quaternary older alluvium; Tyg, Tertiary younger sedimentary deposits; Tog, Tertiary older sedimentary deposits; NA, not applicable; 1/d, one per day; acre-ft/yr, acre-foot per year]

\begin{tabular}{|c|c|c|c|c|c|c|c|}
\hline \multicolumn{8}{|c|}{ A. Drain properties } \\
\hline $\begin{array}{l}\text { Zone } \\
\text { name }\end{array}$ & $\begin{array}{c}\text { Initial } \\
\text { horizontal } \\
\text { hydraulic } \\
\text { conductivity } \\
\text { Kh } \\
\text { (ft/d) } \\
\end{array}$ & $\begin{array}{c}\text { Calibrated } \\
\text { horizontal } \\
\text { hydraulic } \\
\text { conductivity } \\
\text { Kh } \\
\text { (ft/d) } \\
\end{array}$ & $\begin{array}{c}\text { Vertical } \\
\text { anisotropy } \\
\text { (dimensionless) }\end{array}$ & $\begin{array}{c}\text { Initial } \\
\text { specific } \\
\text { yield } \\
\text { (dimensionless) }\end{array}$ & $\begin{array}{l}\text { Calibrated specific } \\
\text { yield } \\
\text { (dimensionless) }\end{array}$ & $\begin{array}{c}\text { Initial } \\
\text { specific } \\
\text { storage } \\
\left(\mathrm{ft}^{-1}\right)\end{array}$ & $\begin{array}{l}\text { Calibrated specific } \\
\text { storage } \\
\left(\mathrm{ft}^{\prime} \mathbf{t}^{\prime}\right.\end{array}$ \\
\hline \multicolumn{8}{|c|}{ Model layer 1} \\
\hline $\mathrm{Qp}$ & 1.00 & 1.50 & $1: 500$ & 0.1 & 0.01 & NA & NA \\
\hline Qoa & $3.00-30.00$ & 3.00 and 5.6 & $1: 500$ & 0.5 & 0.1 & NA & NA \\
\hline Tyg & $3.00-7.00$ & 5.00 & $1: 500$ & 0.5 & 0.1 & NA & NA \\
\hline Tog & 2.00 & 2.50 & $1: 500$ & 0.5 & 0.1 & NA & NA \\
\hline Tog & 2.00 & 2.00 & $1: 500$ & NA & NA & $1.0 \mathrm{E}-5$ & $1.0 \mathrm{E}-6$ \\
\hline \multicolumn{4}{|c|}{ C. Hydraulic characteristics of the horizontal-flow barriers } & \multicolumn{4}{|c|}{ D. Recharge rates } \\
\hline \multicolumn{2}{|c|}{ Zone name } & \multicolumn{2}{|c|}{ Hydraulic characteristic $(\mathbf{1} / \mathbf{d})$} & \multicolumn{2}{|c|}{ Zone name } & \multicolumn{2}{|c|}{ Recharge (acre-ft/yr) } \\
\hline \multicolumn{2}{|c|}{ Unnamed north (layers 1, 2 and 3) } & \multicolumn{2}{|c|}{$1.00 \mathrm{E}-06$} & \multicolumn{2}{|c|}{ Underflow } & \multicolumn{2}{|c|}{$6.00-40.00$} \\
\hline \multicolumn{2}{|c|}{ Playa (layer 1) } & \multicolumn{2}{|c|}{$1.0 \mathrm{E}-06$ and $1.0 \mathrm{E}-02$} & \multicolumn{2}{|c|}{ Noble Dome } & \multicolumn{2}{|c|}{1.80} \\
\hline \multicolumn{2}{|c|}{ Playa (layers 2 and 3 ) } & \multicolumn{2}{|c|}{$1.00 \mathrm{E}-06$} & \multicolumn{2}{|c|}{ Alvord } & \multicolumn{2}{|c|}{4.00} \\
\hline \multicolumn{2}{|c|}{ Noble Dome (layer 1) } & \multicolumn{2}{|c|}{$1.0 \mathrm{E}-5$ and $4.0 \mathrm{E}-03$} & \multicolumn{2}{|l|}{ Total } & \multicolumn{2}{|c|}{$11.8-45.8$} \\
\hline \multicolumn{2}{|c|}{ Noble Dome (layers 2 and 3) } & \multicolumn{2}{|c|}{$1.00 \mathrm{E}-06$} & & & & \\
\hline \multicolumn{2}{|c|}{ Coyote Lake (layers 1, 2, and 3) } & \multicolumn{2}{|c|}{10.00} & & & & \\
\hline
\end{tabular}




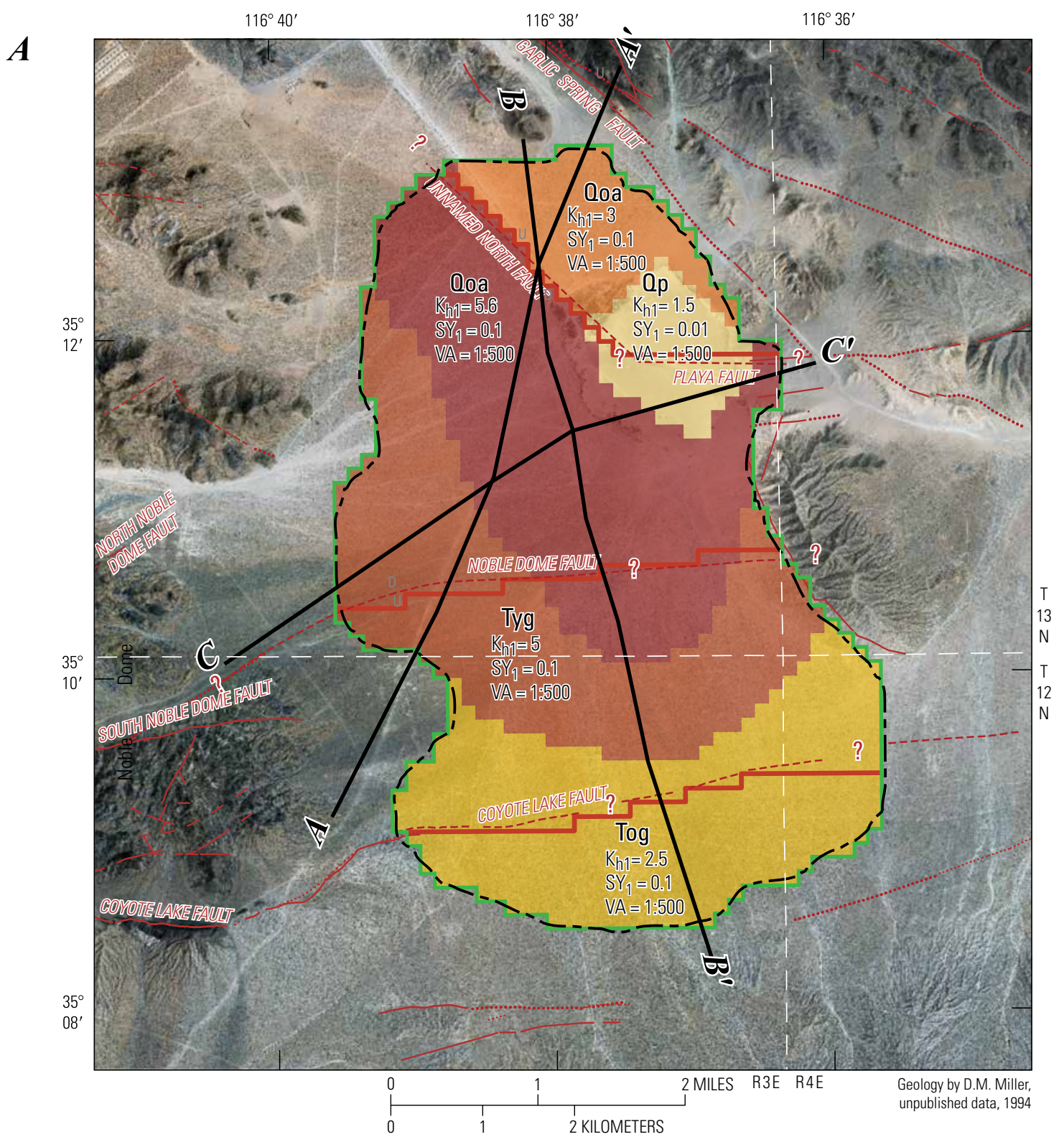

\section{EXPLANATION}

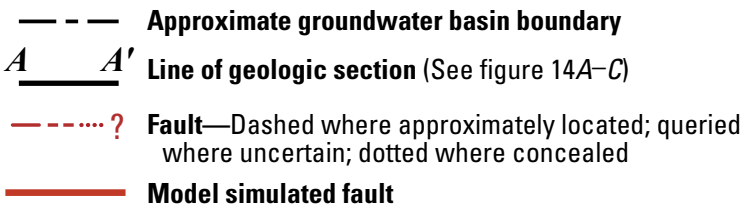

\begin{tabular}{cl}
\hline Qoa & Geologic zone \\
$K_{h 1}=5.6$ & Horizontal hydraulic-conductivity value, in feet per day \\
$S Y_{1}=0.1$ & Specific-yield value, dimensionless \\
$V A=1: 500$ & Vertical anisotropy, dimensionless
\end{tabular}

Figure 16. Areal distribution of hydraulic parameter zones, horizontal hydraulic conductivity, specific yield (layer 1), specific storage, vertical anisotropy, and horizontal-flow barriers used in the model for $A$, model layer $1 ; B$, model layer 2 ; and $C$, model layer 3 for the calibrated transient groundwater-flow model, Langford Basin, Fort Irwin National Training Center, California. 


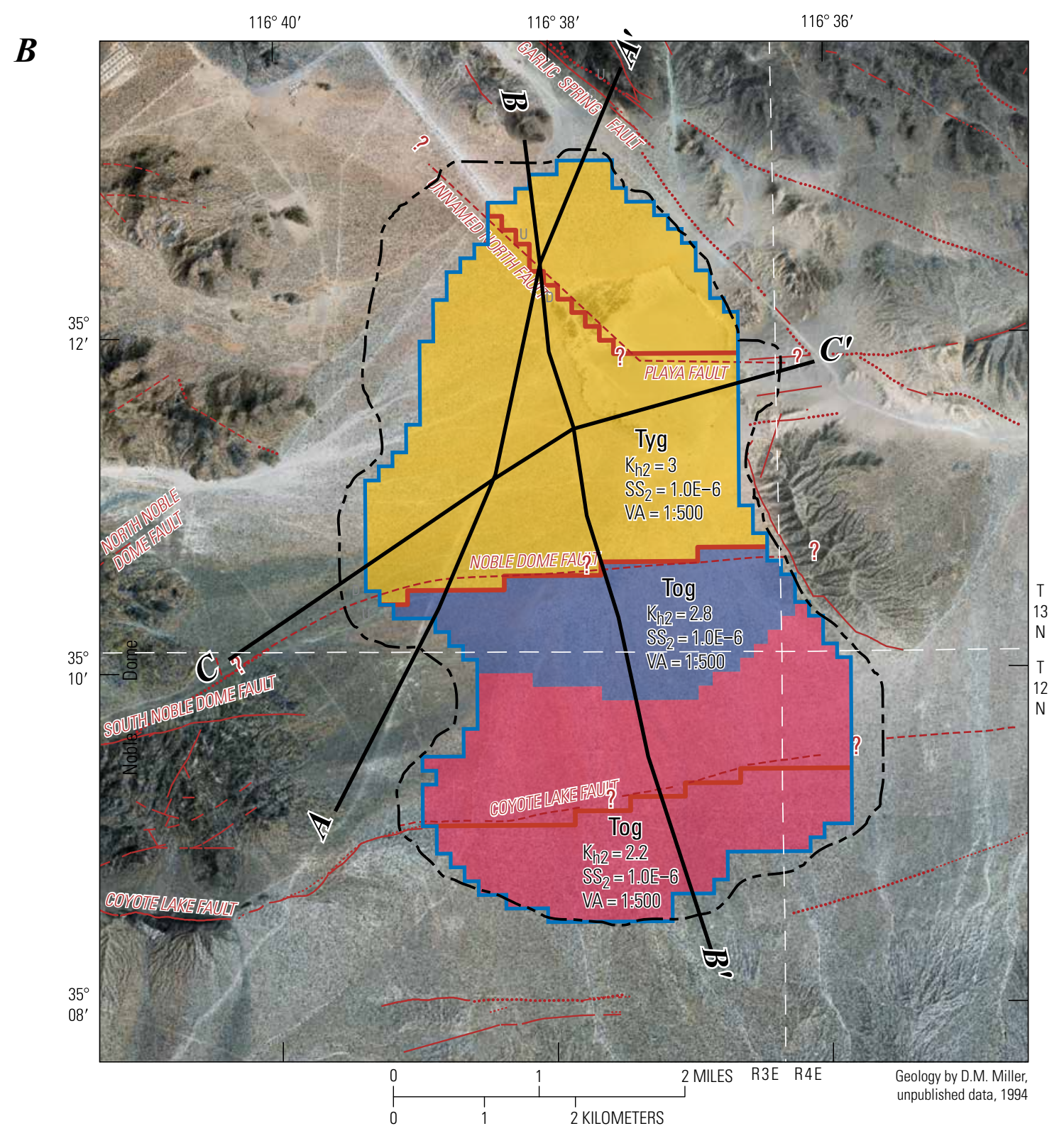

EXPLANATION

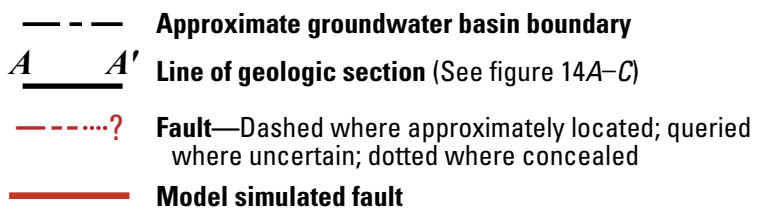

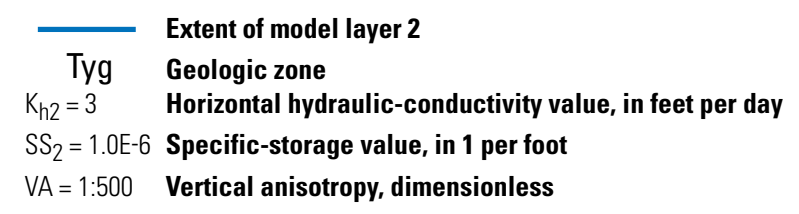

Figure 16. Areal distribution of hydraulic parameter zones, horizontal hydraulic conductivity, specific yield (layer 1), specific storage, vertical anisotropy, and horizontal-flow barriers used in the model for $A$, model layer 1; $B$, model layer 2; and $C$, model layer 3 for the calibrated transient groundwater-flow model, Langford Basin, Fort Irwin National Training Center, California.—Continued 


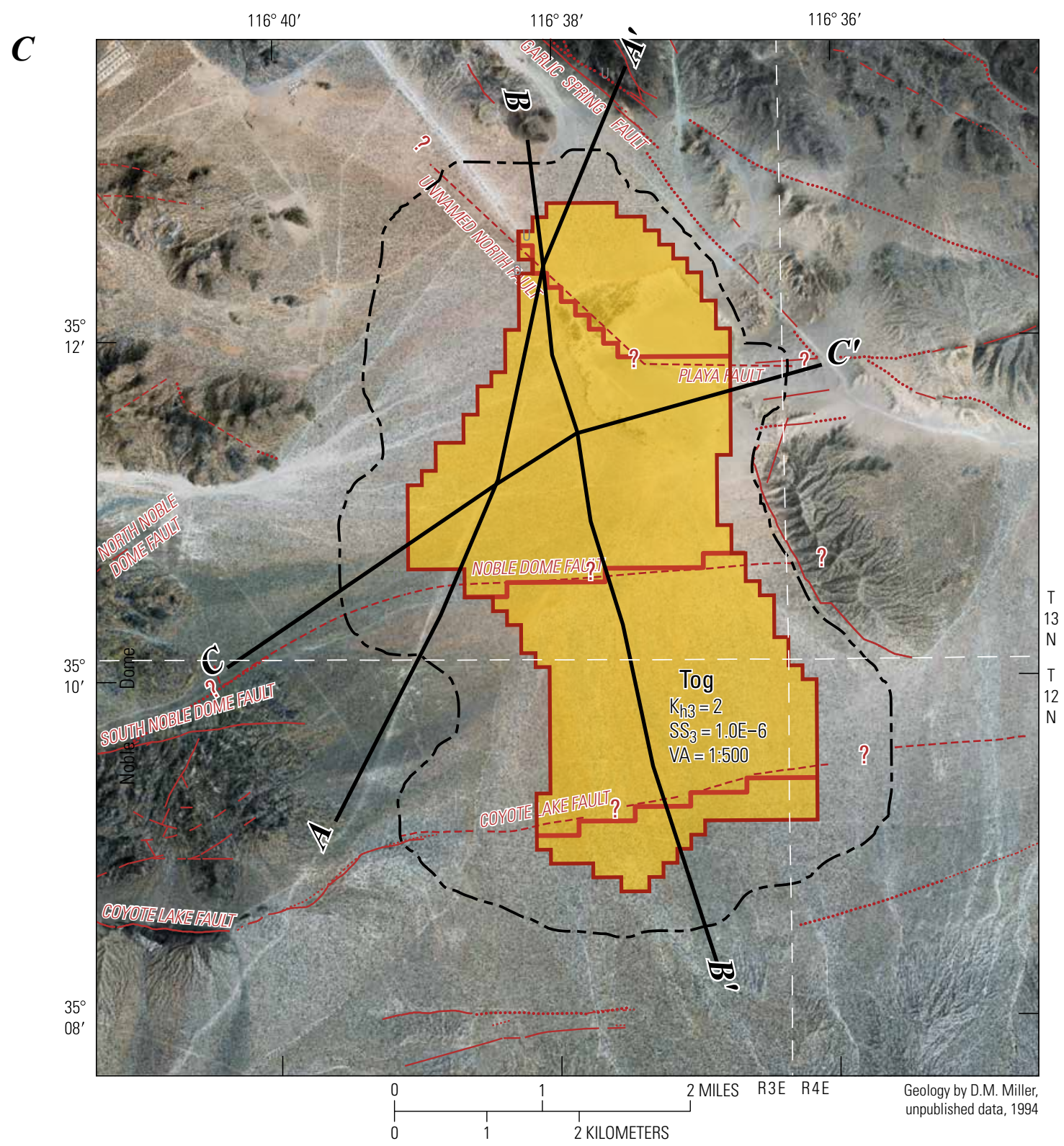

EXPLANATION

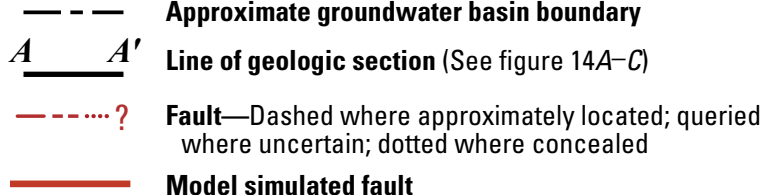

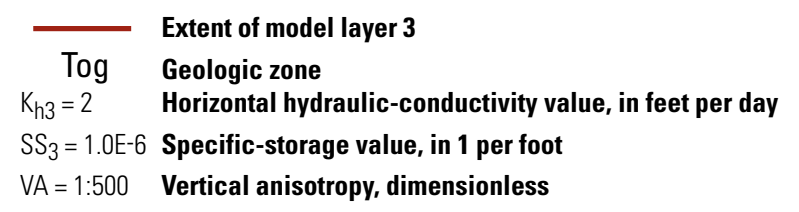

Figure 16. Areal distribution of hydraulic parameter zones, horizontal hydraulic conductivity, specific yield (layer 1), specific storage, vertical anisotropy, and horizontal-flow barriers used in the model for $A$, model layer $1 ; B$, model layer 2; and $C$, model layer 3 for the calibrated transient groundwater-flow model, Langford Basin, Fort Irwin National Training Center, California.—Continued 


\section{Vertical Leakance}

The hydraulic connection (vertical leakance or leakage) between model layers is calculated by the MODFLOW program by using the thickness of the model layer and the vertical hydraulic conductivity of the model layer to calculate the vertical leakage for each model cell (Harbaugh, 2005). For this model, the vertical hydraulic conductivity was calculated as a fraction of the horizontal hydraulic conductivity. The ratio of horizontal hydraulic conductivity $(\mathrm{Kh})$ to vertical hydraulic conductivity (Kv) - vertical anisotropy - was calibrated to be 1:500. Simulated vertical leakage between model cells only occurs where there is an underlying active model cell.

\section{Specific Yield and Specific Storage}

A specific yield was estimated through model calibration for each of the hydraulic property zones in model layer 1 (fig. 16A). Specific storage was estimated through model calibration for each zone in model layers 2 and 3. Initial estimates for these storage properties were determined from the geologic properties of the aquifer materials. Initial specific-yield values for all zones in model layer 1 were 0.10 or 0.5 , and initial specific storages for all zones in model layers 2 and 3 were $1.0 \times 10^{-5} \mathrm{ft}^{-1}$. Final specific-yield values ranged from 0.01 to 0.1 in model layer 1 (fig. $16 A$, table $4 B$ ). The final specificyield value of 0.1 was used everywhere in model layer 1 except for the sediments in the area of the playa $(\mathrm{Qp})$, where a value of 0.01 was used. The final specific-storage values for model layers 2 and 3 were $1.0 \times 10^{-6} \mathrm{ft}^{-1}$ (fig. $16 B$ and $16 C$, table $4 B$ ).

\section{Horizontal-Flow Barriers}

Faults are barriers to groundwater flow in the Langford Basin. Low permeability faults were simulated by using the Horizontal-Flow Barrier module, which modifies the hydraulic conductivity between adjacent model cells (Hsieh and Freckleton, 1993). Flow across a simulated fault is proportional to the hydraulic-head difference between adjacent cells. The constant of proportionality is a specific value, the hydraulic characteristic, that is equal to the barrier hydraulic conductivity divided by the width of the horizontal-flow barrier. The initial locations and areal extents of these barriers were identified by extending mapped faults into the basin and are described in the "Fault" section of this report. Hydraulically significant faults were inferred from measured differences in groundwater-level declines between production wells and monitor wells, and from model calibration. The hydraulic characteristic initially was set to $1.0 \mathrm{1} / \mathrm{d}$. For each horizontal-flow barrier, the hydraulic characteristic was calibrated to simulate groundwater-level declines and drawdown throughout the model calibration period. Fault locations also were adjusted during model calibration to better match simulated and observed water-level declines. Currently, no data are available in the Coyote Lake
Fault area to determine the conductance for this fault. A high value of 10.0 1/d was used for the Coyote Lake Fault so that simulated flow through the fault was not impeded. Final values for all other faults ranged from $1.0 \times 10^{-6}$ to $1.0 \times 10^{-2} 1 / \mathrm{d}$ (table $4 C$ ). Locations of simulated faults are shown on figure 16 .

\section{Simulation of Recharge and Discharge}

Recharge to the Langford Basin occurs as natural recharge of precipitation runoff along normally dry washes near the base of the surrounding hills and as groundwater underflow from the Irwin Basin. As previously stated, areal recharge from direct infiltration of precipitation is believed to be minimal because of the low precipitation and high evaporation rates in the basin. Isotopic data presented earlier in this report indicate the basin was recharged thousands of years ago when the climate was cooler and wetter. The small amount of natural recharge that does take place in the arid Mojave Desert under current climatic conditions results primarily from the infiltration of intermittent runoff along washes (Izbicki and others, 2000).

Natural recharge of precipitation runoff in Langford Basin was simulated in layer 1 with the MODFLOW Recharge module (Harbaugh, 2005) along intermittent streams at the base of Noble Dome (Noble Dome zone) in the western part of the basin and at the base of the Alvord Mountains (Alvord zone) in the southern part of the basin (fig. 17). The initial estimate of natural recharge of precipitation runoff used to calibrate the model was $50 \mathrm{acre-ft} / \mathrm{yr}$. It was assumed that the natural recharge in Langford Basin was similar to the estimated natural recharge for Irwin Basin (50 acre-ft/yr) reported by Densmore (2003). The initial value of $50 \mathrm{acre}-\mathrm{ft} / \mathrm{yr}$ was lowered to about 6 acre-ft/yr during model calibration; most of this recharge was simulated in the Alvord zone (4 acre-ft/yr; table $4 D$ ). The recharge was equally distributed among the cells that represent the simulated recharge areas at the base of the mountains. Recharge at the base of these mountains was assumed to be constant during the entire simulated time period.

Recharge by groundwater underflow from the Irwin Basin was simulated in layer 1 along the Garlic Spring Fault in the northern part of the Langford Basin (fig. 17). Groundwater underflow out of the Irwin Basin ranged from about 50 acre- $\mathrm{ft} / \mathrm{yr}$ under predevelopment conditions to about 105 acre-ft/yr in 1999 (Densmore, 2003). Some of this underflow may be lost to evapotranspiration by phreatophytes near Garlic Spring. Water levels in observation well 13N/3E-10E3 (well location shown on fig. 13), in the southeastern part of the Irwin Basin, have increased since 1995 in response to importation of water withdrawn from the Bicycle and Langford Basins and the subsequent recharge of treated wastewater effluent in the southeastern part of the Irwin Basin (Densmore, 2003). This increase in the application of recharge in the Irwin Basin has resulted in an increase in the underflow out of the Irwin Basin along the Garlic Spring Fault. Water levels in well 


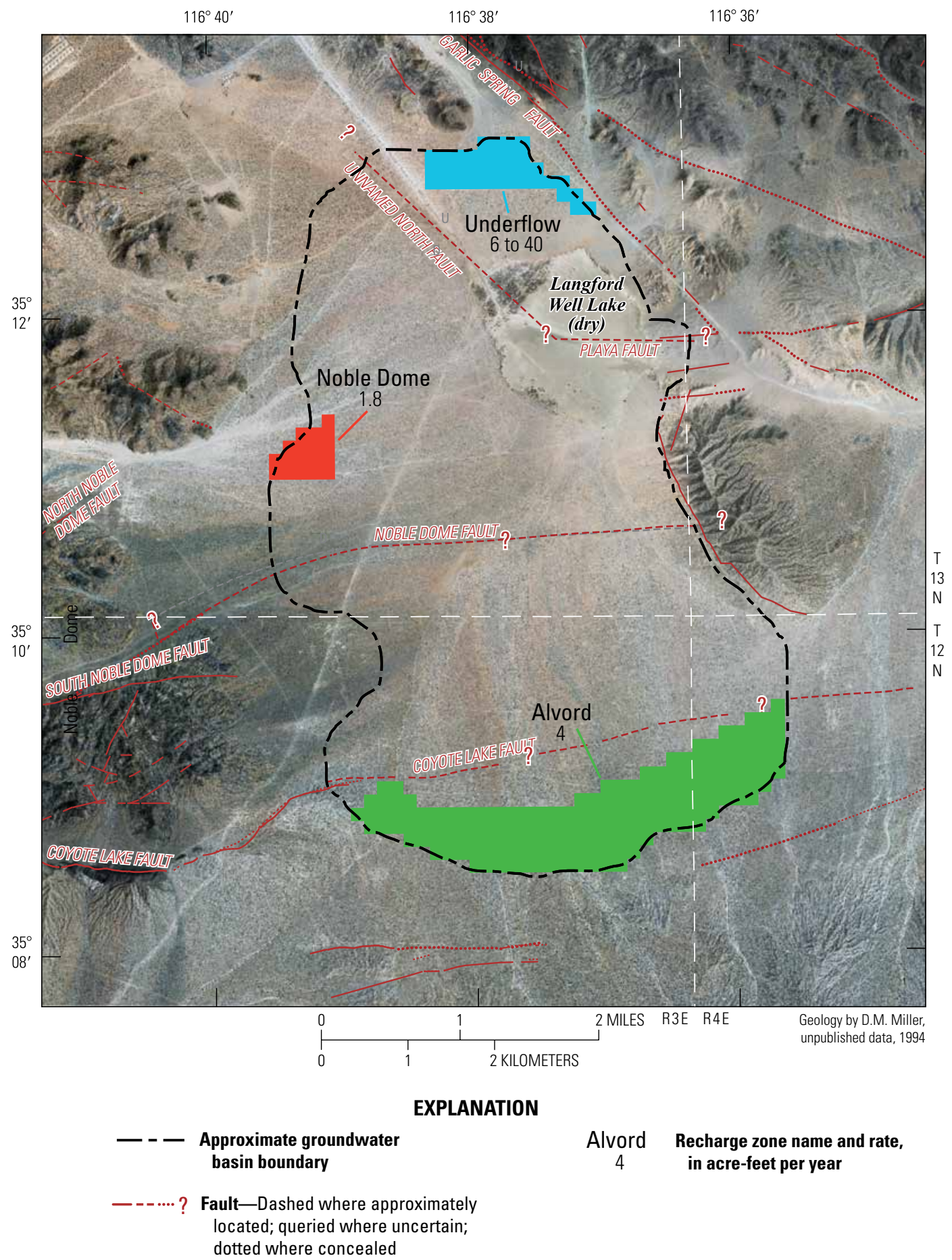

Figure 17. Recharge distribution zones and recharge rates for the calibrated transient groundwater-flow model, Langford Basin, Fort Irwin National Training Center, California. 
$13 \mathrm{~N} / 3 \mathrm{E}-14 \mathrm{~K} 1$, in the northern part of the Langford Basin, have risen $3 \mathrm{ft}$ since June 1999 when measurements began (fig. 19, presented later in report). The water-level rise in well 13N/3E-14K1 is assumed to be the result of an increase in underflow from Irwin Basin. The quantity and timing of the groundwater underflow was adjusted to match measured water levels at well 13N/3E-14K1 during the model calibration. Final calibrated values of underflow are 6 acre-ft/yr for predevelopment and for January 1993 to December 1997, and 40 acre-ft/yr for January 1999 to December 2010 (table 5). After groundwater withdrawals began in April 1992, a value of 4.5 acre-ft/yr was used to simulate underflow for April 1992 to December 1992, which is not a full year. The increase in simulated groundwater underflow in 1999 is the result of increased net inflow of water to the Irwin Basin owing to importation of water withdrawn from the Bicycle and Langford Basins (Densmore, 2003).

As previously stated, there is no surface-water discharge from the basin. During predevelopment conditions, groundwater underflow is presumed to discharge east of the playa and was simulated by use of the MODFLOW Drain module (Harbaugh, 2005) described previously.

\section{Groundwater Withdrawals}

The MODFLOW Multi-Node Well module, MNW2 (Konikow and others, 2009), was used to simulate groundwater withdrawals from three production wells in the Langford
Basin, which were previously discussed in the "Groundwater Withdrawals and Water Use" section of the report. The MNW2 module simulates wells completed in multiple aquifers and allows vertical groundwater movement through the well bores. The groundwater withdrawal rate at an individual well is distributed dynamically into model layers (multi-well nodes) on the basis of transmissivity, water level, and the length of the screened interval in each layer. Groundwater withdrawals from each well were allocated between model layers 1 and 2 . The screened intervals of the three production wells in Langford Basin do not extend into layer 3.

\section{Model Calibration}

The model was calibrated by trial-and-error adjustment of initial estimates of hydraulic conductivity, vertical anisotropy, specific-yield values, specific-storage values, hydraulic characteristic of the horizontal-flow barriers, underflow from the Irwin Basin, recharge rates, and conductance and elevation of the drain. The calibration criteria for the Langford model are to minimize the difference between simulated and measured water levels at 12 observation wells, simulate general flow directions, and simulate the temporal trend in measured water levels. During model calibration, the hydraulic-property values were adjusted within limits based on the geologic and hydrologic properties of the basin and the degree of confidence placed on the original data estimates. The model calibration included adjusting the locations of horizontal-flow barriers, which had a major effect on the simulated water levels.

Table 5. Simulated predevelopment and annual water budget, 1992-2010, Langford Basin, Fort Irwin National Training Center, California.

[Values in acre-feet per year. *, groundwater withdrawals and simulation period begins in April 1992]

\begin{tabular}{|c|c|c|c|c|c|c|c|c|}
\hline \multirow{2}{*}{ Time interval } & \multicolumn{4}{|c|}{ Inflows } & \multicolumn{4}{|c|}{ Outflows } \\
\hline & Recharge & Underflow & Storage & Total & Withdrawals & Drains & Storage & Total \\
\hline $1992 *$ & 4.3 & 4.5 & 575.0 & 583.8 & 560.5 & 7.5 & 15.8 & 583.8 \\
\hline 1994 & 5.8 & 6 & $1,004.1$ & $1,015.9$ & 904.6 & 0.0 & 111.3 & $1,015.9$ \\
\hline 1995 & 5.8 & 6 & 871.3 & 883.1 & 732.4 & 0.0 & 150.7 & 883.1 \\
\hline 1996 & 5.8 & 6 & 730.7 & 742.5 & 594.4 & 0.0 & 148.1 & 742.5 \\
\hline 1999 & 5.8 & 40 & 657.1 & 702.9 & 473.0 & 0.0 & 229.9 & 702.9 \\
\hline 2000 & 5.8 & 40 & 664.1 & 709.9 & 582.2 & 0.0 & 127.7 & 709.9 \\
\hline 2001 & 5.8 & 40 & 432.9 & 478.7 & 234.1 & 0.0 & 244.6 & 478.7 \\
\hline 2002 & 5.8 & 40 & 474.7 & 520.5 & 383.7 & 0.0 & 136.8 & 520.5 \\
\hline 2003 & 5.8 & 40 & 701.6 & 747.4 & 618.0 & 0.0 & 129.4 & 747.4 \\
\hline 2008 & 5.8 & 40 & 855.5 & 901.3 & 854.8 & 0.0 & 46.5 & 901.3 \\
\hline 2009 & 5.8 & 40 & 852.1 & 897.9 & 792.0 & 0.0 & 105.9 & 897.9 \\
\hline 2010 & 5.8 & 40 & 959.9 & $1,005.7$ & 899.6 & 0.0 & 106.1 & $1,005.7$ \\
\hline 1992-2010 Total & 108.7 & 540.5 & $14,396.9$ & $15,046.1$ & $12,308.2$ & 10.7 & $2,726.9$ & $15,045.8$ \\
\hline
\end{tabular}


The model was calibrated in an iterative manner between the steady state and transient simulations. Starting with the steady-state model, an initial hydraulic-head distribution for predevelopment conditions was simulated by modifying the initial estimates of the drain elevation and conductance, horizontal hydraulic conductivity, and recharge. The simulated head distribution from the steady-state model was then used as the initial head distribution for the transient model. The transient calibration primarily involved modifying storage properties, the hydraulic-characteristic values of the horizontal-flow barriers (faults), and the vertical-anisotropy values. If a satisfactory match between measured and simulated results was not obtained, the process was repeated.

A semi-automated calibration process such as UCODE (Poeter and others, 2005) was not utilized for this study because of the lack of data; only one type of data, hydraulic heads, are available for the Langford Basin. Hill and Tiedeman (2007) discussed problems associated with using only one type of data when a semi-automated calibration process such as UCODE is utilized for calibration. When only hydraulic head observations are included and parameters related to the flows and hydraulic conductivity of the system are being estimated by the regression, the same value of the objective function can be calculated from numerous combinations of the parameters; hence, no set of unique values will be estimated (Hill and Tiedeman, U.S. Geological Survey, written commun., 2011).

Predevelopment conditions were used to simulate steadystate conditions during stress period 1 . The model was calibrated to the highest groundwater-level measurements made prior to 1992 (figs. 7 $A$ and 18A). Water-level measurements were available from only five wells $(13 \mathrm{~N} / 3 \mathrm{E}-23 \mathrm{~F} 1,13 \mathrm{~N} / 3 \mathrm{E}-$ $26 \mathrm{~N} 1,13 \mathrm{~N} / 3 \mathrm{E}-26 \mathrm{~N} 2,13 \mathrm{~N} / 3 \mathrm{E}-35 \mathrm{~B} 1$, and 13N/3E-34Q1) for the period from 1980 to 1988 . Well $13 \mathrm{~N} / 3 \mathrm{E}-23 \mathrm{~F} 1$ is screened in all layers, wells 13N/3E-35B1, 13N/3E-26N1, and 13N/3E$26 \mathrm{~N} 2$ are screened in layers 1 and 2, and well 13N/3E-34Q1 is screened in layer 1 . No groundwater-level measurements were available for the southern half of the basin. The steady-state calibration primarily involved modifying the initial estimates of the drain elevation and conductance, horizontal hydraulic conductivity, and recharge until simulated hydraulic heads were within $5 \mathrm{ft}$ of the measured predevelopment water levels. The calibrated hydraulic-conductivity values were similar to values derived from specific-capacity tests (table 2). Simulated hydraulic heads for predevelopment conditions were within $\pm 1.9 \mathrm{ft}$ of measured water levels, with a root mean squared error (RMSE) of $1.5 \mathrm{ft}$ (table 6). The simulated groundwater budget for predevelopment conditions is shown in table 5 .

Groundwater conditions from April 1992 through March 2011 were used to simulate transient conditions during stress periods 2-229. The model was calibrated to water levels measured between January 1993 and December 2010. A total of 117 groundwater-level measurements from 12 wells were used to calibrate the model. Water levels measured in the three production wells were not used in the calibration process if the wells were pumping or were recently pumped. The transient calibration primarily involved modifying storage properties, the hydraulic-characteristic values of the horizontal-flow barriers (faults), and the vertical-anisotropy values. Groundwater withdrawals were metered and were not modified during the calibration. The barrier effect of the faults on groundwater flow was not evident until the aquifer system was stressed by groundwater withdrawals. Consequently, the transient calibration process involved modifying the hydraulic-characteristic values of horizontal-flow barrier segments near pumping wells to approximate hydraulic-head declines measured in long-term monitor wells.

The simulated layer-1 hydraulic heads agreed well with measured water levels for March 1995, March 2005, and October 2010 (fig. 18B, 18C, and 18D, respectively), and the simulated drawdown from April 1992 to December 2010 compared well to the measured drawdown at the three production wells in the Langford Basin (fig. 18E). The RMSE for the transient simulation is $9.3 \mathrm{ft}$ (table 6). The greatest differences between simulated hydraulic heads and measured water levels are in monitor wells 13N/3E-26K2, 13N/3E-26K3, and 13N/3E-26K4 for May 1995, August 2002, and October 2010. These monitor wells are within $200 \mathrm{ft}$ of production well 13N/3E-26K1. Water levels in the monitor wells fluctuate more than $50 \mathrm{ft}$ during the same time period, in response to pumping in the production well. Hydraulic heads were simulated using average monthly withdrawal rates for the different production wells; consequently, daily responses to the wells turning on and off are not simulated. Simulated hydraulic heads represent an average for a model cell over the month-long simulation period. Monitor wells 13N/3E-35J1, $13 \mathrm{~N} / 3 \mathrm{E}-35 \mathrm{~J} 2,13 \mathrm{~N} / 3 \mathrm{E}-35 \mathrm{~J} 3,13 \mathrm{~N} / 3 \mathrm{E}-14 \mathrm{~K} 1,13 \mathrm{~N} / 3 \mathrm{E}-23 \mathrm{~F} 1$, $13 \mathrm{~N} / 3 \mathrm{E}-26 \mathrm{~N} 1$, and $13 \mathrm{~N} / 3 \mathrm{E}-34 \mathrm{Q} 1$ are more than $0.6 \mathrm{mi}$ from the nearest production well and are not affected by daily fluctuations in withdrawal rates. The RMSE from these wells is less than $3.5 \mathrm{ft}$.

Simulated time-series of hydraulic heads (hydrographs) for the period 1992 through 2010 from the calibrated model closely match the hydrographs of measured water levels (fig. 19). These results indicate the transient simulation reasonably simulates the timing and magnitude of water-level declines in Langford Basin. The greatest difference between simulated and measured water levels is in the three monitor wells $13 \mathrm{~N} / 3 \mathrm{E}-26 \mathrm{~K} 2,13 \mathrm{~N} / 3 \mathrm{E}-26 \mathrm{~K} 3$, and $13 \mathrm{~N} / 3 \mathrm{E}-26 \mathrm{~K} 4$ that are near production wells. 


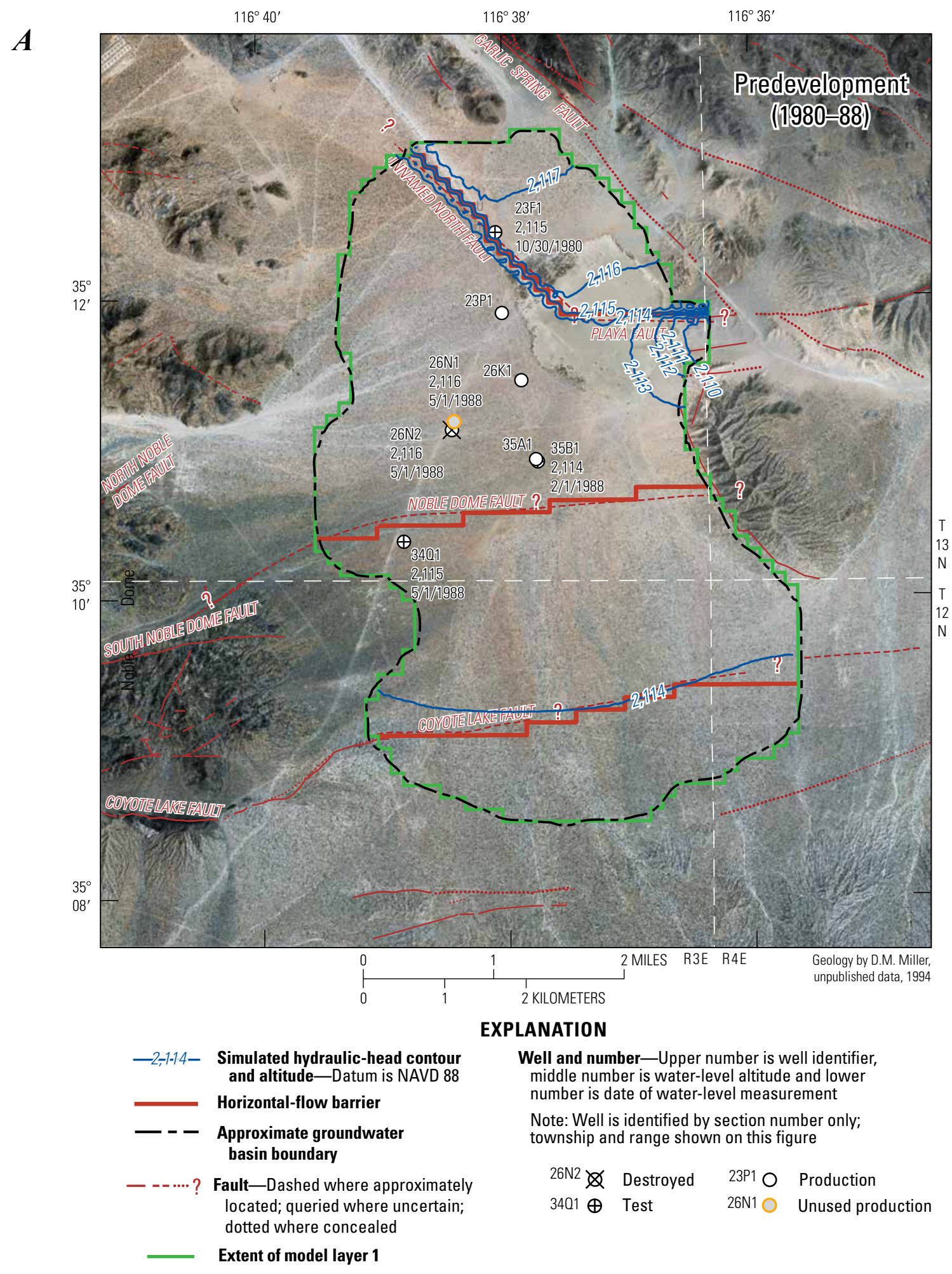

Figure 18. Simulated water-table surface and measured water levels for the upper aquifer, Langford Basin, Fort Irwin National Training Center, California. A, Predevelopment; B, February 1995; C, March 2005; D, October 2010; and E, Simulated drawdown from April 1992 to October 2010. 


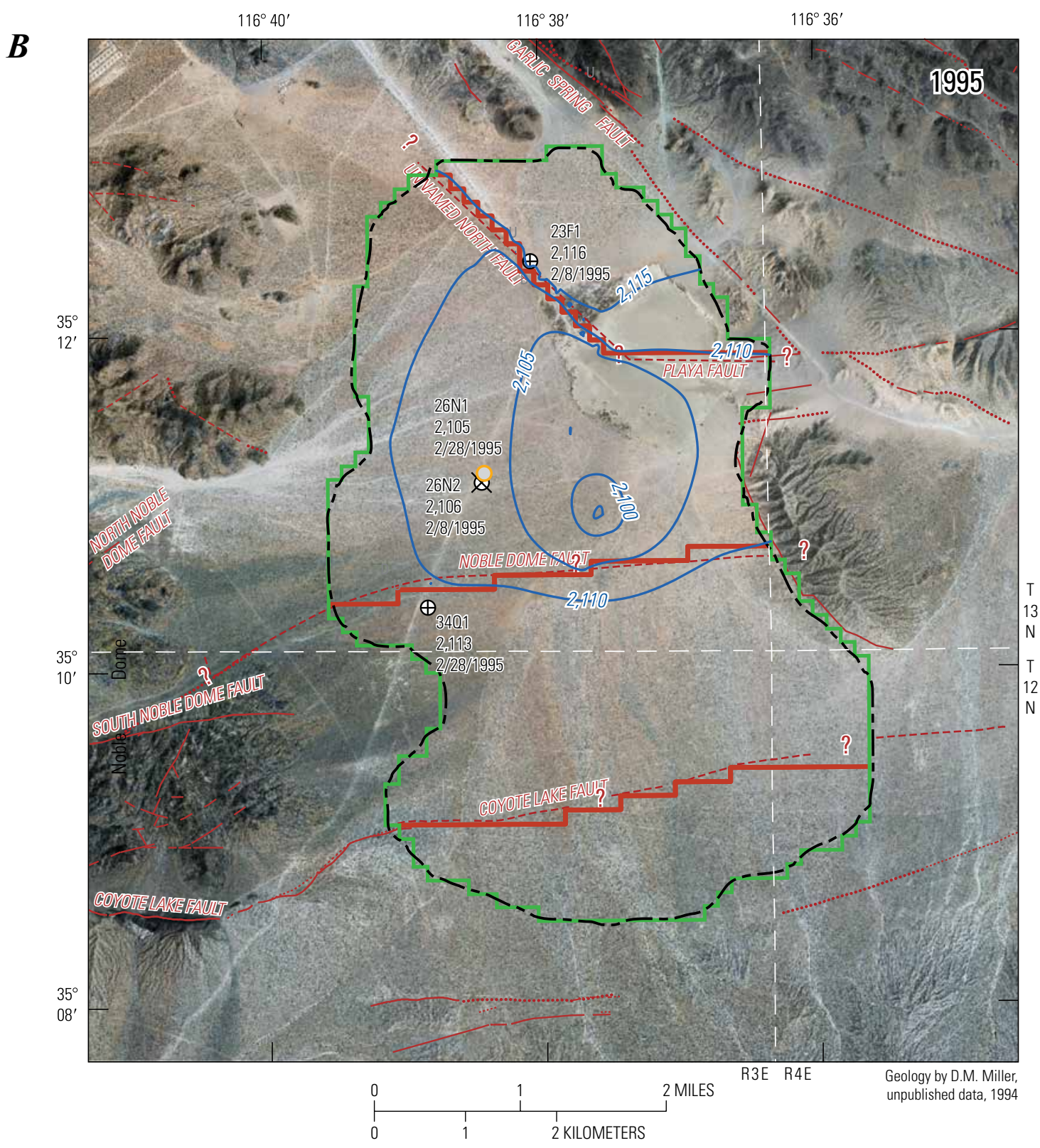

\section{EXPLANATION}

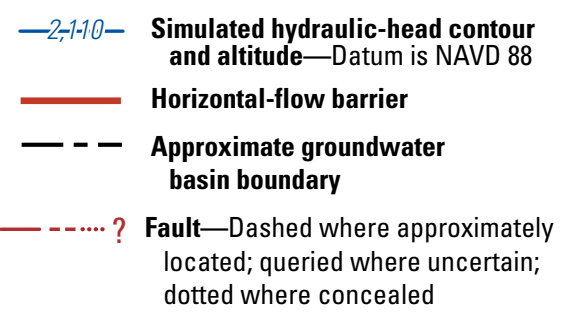

dotted where concealed
Well and number-Upper number is well identifier, middle number is water-level altitude and lower number is date of water-level measurement

Note: Well is identified by section number only; township and range shown on this figure

$$
\begin{array}{llll}
26 \mathrm{~N} 2 & \text { Destroyed } & \text { 23P1 } \bigcirc & \text { Production } \\
3401 \oplus & \text { Test } & 26 \mathrm{~N} 1 \bigcirc & \text { Unused production }
\end{array}
$$

Figure 18. Simulated water-table surface and measured water levels for the upper aquifer, Langford Basin, Fort Irwin National Training Center, California. A, Predevelopment; B, February 1995; C, March 2005; D, October 2010; and E, Simulated drawdown from April 1992 to October 2010.-Continued 


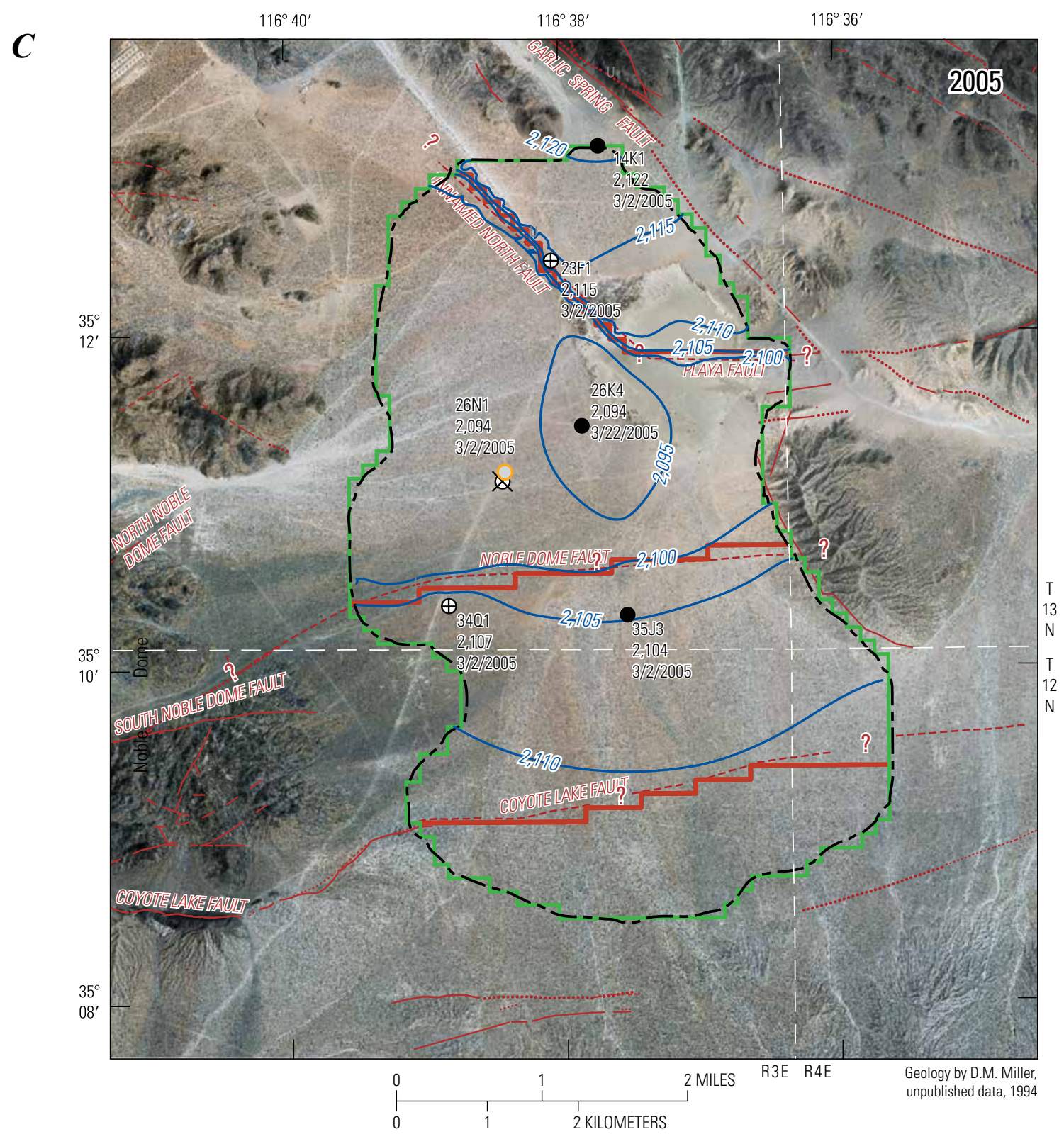

\section{EXPLANATION}

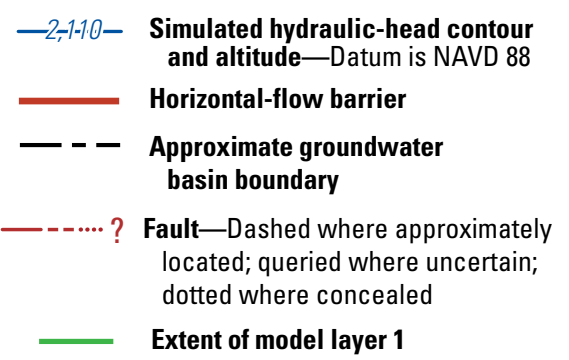

Well and number-Upper number is well identifier, middle number is water-level altitude and lower number is date of water-level measurement

Note: Well is identified by section number only; township and range shown on this figure

\begin{tabular}{|c|c|c|c|}
\hline $26 \mathrm{~N} 2 \not$ & Destroyed & 23P1 $\mathrm{O}$ & Production \\
\hline $3401 \oplus$ & Test & $26 \mathrm{~N} 1 \bigcirc$ & Unused production \\
\hline 3513 & $\begin{array}{l}\text { U.S. Geolo } \\
\text { Survey }\end{array}$ & & \\
\hline
\end{tabular}

Figure 18. Simulated water-table surface and measured water levels for the upper aquifer, Langford Basin, Fort Irwin National Training Center, California. A, Predevelopment; $B$, February 1995; $C$, March 2005; D, October 2010; and E, Simulated drawdown from April 1992 to October 2010.-Continued 


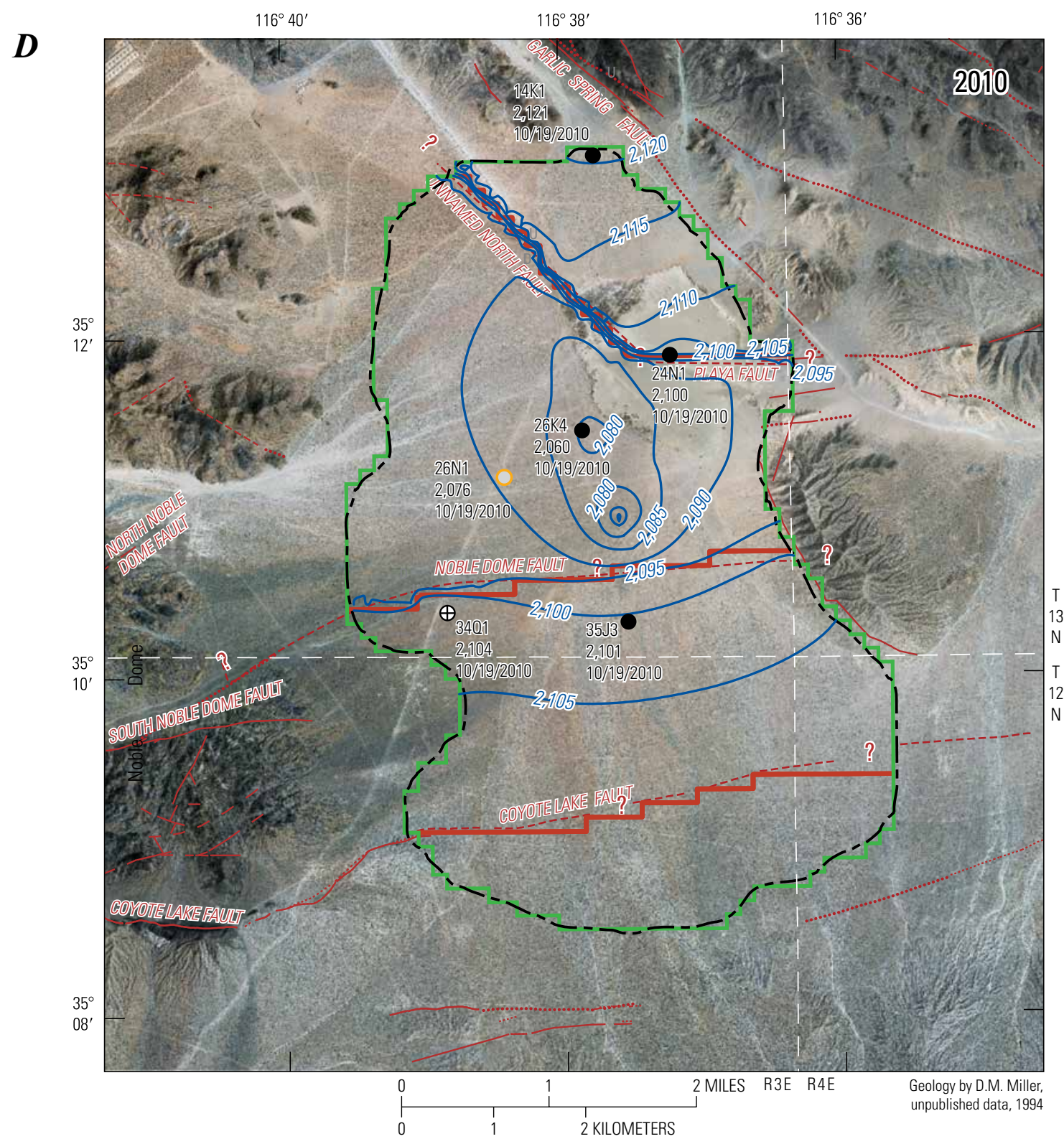

\section{EXPLANATION}

\section{-2,17-10- Simulated hydraulic-head contour and altitude-Datum is NAVD 88}

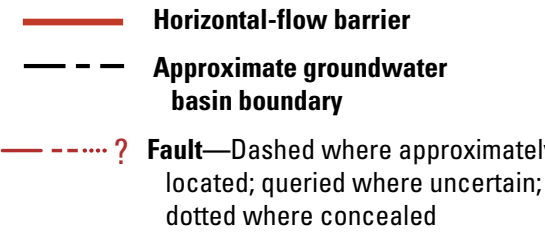
dotted where concealed

Extent of model layer 1
Well and number-Upper number is well identifier middle number is water-level altitude and lower number is date of water-level measurement

Note: Well is identified by section number only; township and range shown on this figure

\begin{tabular}{|c|c|c|c|}
\hline $26 \mathrm{~N} 2 \not$ & Destroyed & ${ }^{23 P 1} \mathrm{O}$ & Production \\
\hline $3401 \oplus$ & Test & $26 \mathrm{~N} 1 \bigcirc$ & Unused production \\
\hline 35J1-3 & $\begin{array}{l}\text { U.S. Geolo } \\
\text { Survey }\end{array}$ & & \\
\hline
\end{tabular}

Figure 18. Simulated water-table surface and measured water levels for the upper aquifer, Langford Basin, Fort Irwin National Training Center, California. A, Predevelopment; $B$, February 1995; $C$, March 2005; D, October 2010; and E, Simulated drawdown from April 1992 to October 2010.-Continued 


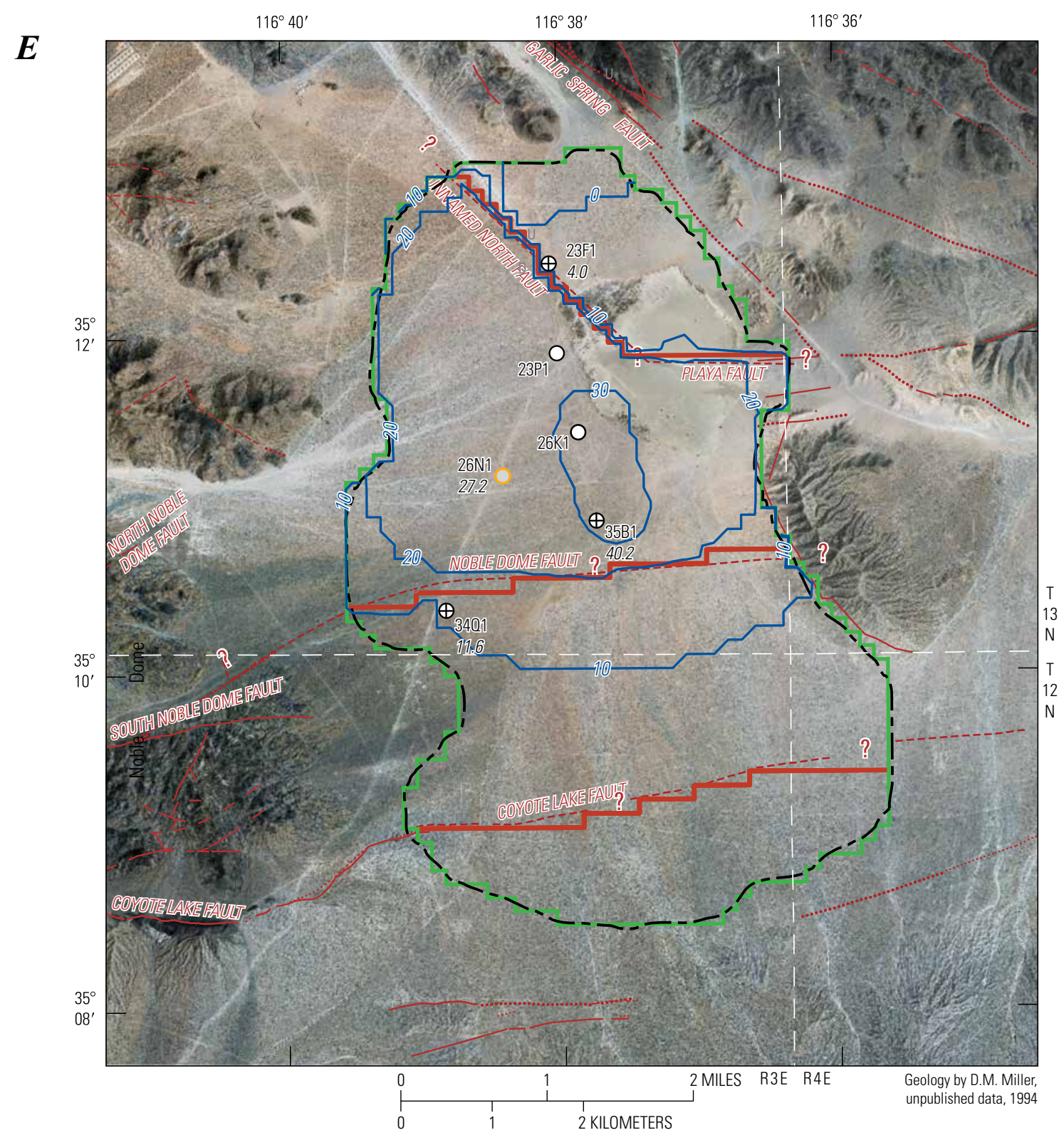

\section{EXPLANATION}

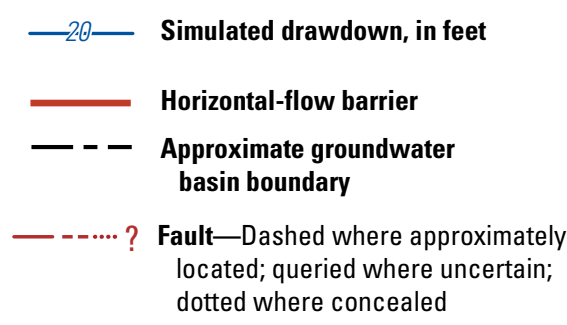
dotted where concealed

Extent of model layer 1
Well and number- Upper number is well identifier, lower number is the drawdown, calculated water-level measurements from Jan or Feb, 1993 and December, 2010

Note: Well identified by section number only; township and range is shown on this figure
23Р1
$23 \mathrm{~F} 1$
4.0

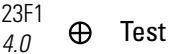
$26 \mathrm{~N} 1$
27.2
Production

Figure 18. Simulated water-table surface and measured water levels for the upper aquifer, Langford Basin, Fort Irwin National Training Center, California. A, Predevelopment; B, February 1995; C, March 2005; D, October 2010; and E, Simulated drawdown from April 1992 to October 2010.-Continued 
Table 6. Simulated and 1993-2011 measured water levels and root mean square error for 12 wells, Langford Basin, Fort Irwin National Training Center, California.

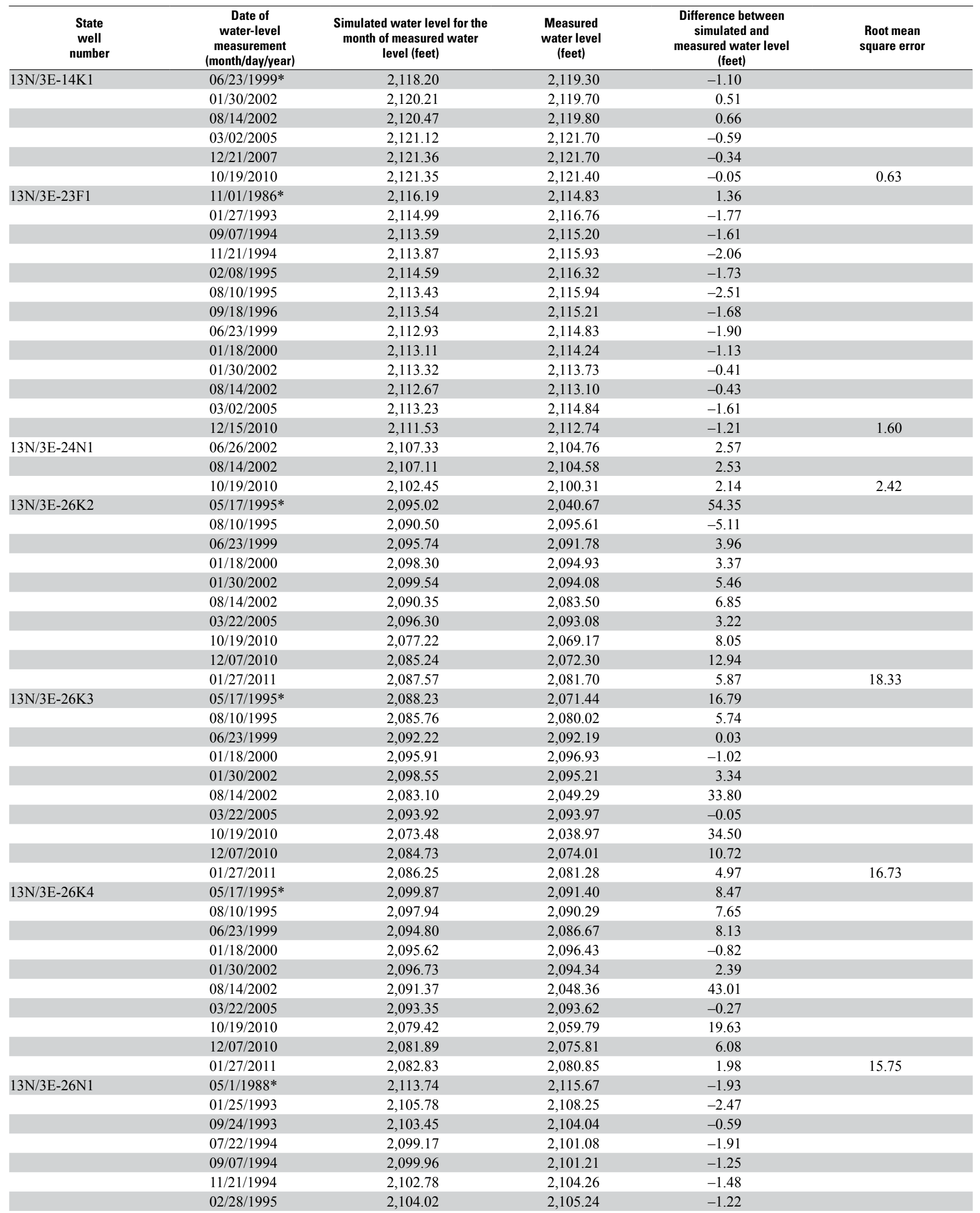


Table 6. Simulated and 1993-2011 measured water levels and root mean square error for 12 wells, Langford Basin, Fort Irwin National Training Center, California.-Continued

\begin{tabular}{|c|c|c|c|c|c|}
\hline $\begin{array}{c}\text { State } \\
\text { well } \\
\text { number }\end{array}$ & $\begin{array}{c}\text { Date of } \\
\text { water-level } \\
\text { measurement } \\
\text { (month/day/year) }\end{array}$ & $\begin{array}{l}\text { Simulated water level for the } \\
\text { month of measured water } \\
\text { level (feet) }\end{array}$ & $\begin{array}{c}\text { Measured } \\
\text { water level } \\
\text { (feet) }\end{array}$ & $\begin{array}{c}\text { Difference between } \\
\text { simulated and } \\
\text { measured water level } \\
\text { (feet) }\end{array}$ & $\begin{array}{l}\text { Root mean } \\
\text { square error }\end{array}$ \\
\hline & $08 / 10 / 1995$ & $2,098.23$ & $2,099.42$ & -1.19 & \\
\hline & 06/23/1999 & $2,097.69$ & $2,096.86$ & 0.83 & \\
\hline & $01 / 18 / 2000$ & $2,099.23$ & $2,098.00$ & 1.23 & \\
\hline & $01 / 30 / 2002$ & $2,099.31$ & $2,095.95$ & 3.36 & \\
\hline & $10 / 19 / 2010$ & $2,083.71$ & $2,076.01$ & 7.70 & \\
\hline & $12 / 07 / 2010$ & $2,087.72$ & $2,081.04$ & 6.68 & 3.49 \\
\hline \multirow[t]{12}{*}{ 13N/3E-34Q1 } & 05/1/1988* & $2,113.54$ & $2,115.26$ & -1.72 & \\
\hline & $01 / 25 / 1993$ & $2,113.51$ & $2,114.74$ & -1.23 & \\
\hline & $09 / 24 / 1993$ & $2,113.37$ & $2,115.34$ & -1.97 & \\
\hline & $07 / 22 / 1994$ & $2,113.03$ & $2,113.74$ & -0.71 & \\
\hline & $09 / 18 / 1996$ & $2,111.57$ & $2,111.97$ & -0.40 & \\
\hline & 06/23/1999 & $2,109.62$ & $2,110.10$ & -0.48 & \\
\hline & $01 / 18 / 2000$ & $2,109.22$ & $2,109.67$ & -0.45 & \\
\hline & $01 / 30 / 2002$ & $2,108.01$ & $2,108.92$ & -0.91 & \\
\hline & $03 / 02 / 2005$ & $2,106.42$ & $2,107.05$ & -0.63 & \\
\hline & $12 / 21 / 2007$ & $2,104.77$ & $2,105.35$ & -0.58 & \\
\hline & $10 / 19 / 2010$ & $2,103.03$ & $2,103.55$ & -0.52 & \\
\hline & $12 / 07 / 2010$ & $2,102.89$ & $2,103.07$ & -0.18 & 0.89 \\
\hline \multirow[t]{6}{*}{$13 \mathrm{~N} / 3 \mathrm{E}-35 \mathrm{~B} 1$} & $02 / 01 / 1988$ & $2,113.36$ & $2,114.37$ & -1.01 & \\
\hline & $01 / 25 / 1993$ & $2,082.12$ & $2,104.16$ & -22.04 & \\
\hline & $09 / 24 / 1993$ & $2,083.51$ & $2,089.46$ & -5.95 & \\
\hline & $07 / 22 / 1994$ & $2,067.77$ & $2,076.99$ & -9.22 & \\
\hline & $03 / 02 / 2005$ & $2,093.13$ & $2,085.04$ & 8.09 & \\
\hline & $12 / 15 / 2010$ & $2,082.00$ & $2,063.95$ & 18.05 & 9.80 \\
\hline \multirow[t]{7}{*}{$13 \mathrm{~N} / 3 \mathrm{E}-35 \mathrm{~J} 1$} & $6 / 25 / 2002 *$ & $2,109.00$ & $2,108.29$ & 0.70 & \\
\hline & $08 / 14 / 2002$ & $2,108.92$ & $2,108.27$ & 0.65 & \\
\hline & $08 / 03 / 2004$ & $2,108.09$ & $2,107.30$ & 0.79 & \\
\hline & $03 / 02 / 2005$ & $2,107.85$ & $2,107.01$ & 0.84 & \\
\hline & $12 / 21 / 2007$ & $2,106.46$ & $2,105.72$ & 0.74 & \\
\hline & $10 / 19 / 2010$ & $2,104.77$ & $2,104.46$ & 0.31 & \\
\hline & $01 / 27 / 2011$ & $2,104.63$ & $2,104.28$ & 0.35 & 0.69 \\
\hline \multirow[t]{6}{*}{$13 \mathrm{~N} / 3 \mathrm{E}-35 \mathrm{~J} 2$} & $08 / 14 / 2002 *$ & $2,108.28$ & $2,107.85$ & 0.43 & \\
\hline & $08 / 03 / 2004$ & $2,107.41$ & $2,106.88$ & 0.53 & \\
\hline & $03 / 02 / 2005$ & $2,107.12$ & $2,106.59$ & 0.53 & \\
\hline & $12 / 21 / 2007$ & $2,105.66$ & $2,105.34$ & 0.32 & \\
\hline & $10 / 19 / 2010$ & $2,103.84$ & $2,103.81$ & 0.03 & \\
\hline & $01 / 27 / 2011$ & $2,103.65$ & $2,103.69$ & -0.04 & 0.38 \\
\hline \multirow[t]{6}{*}{$13 \mathrm{~N} / 3 \mathrm{E}-35 \mathrm{~J} 3$} & $08 / 14 / 2002 *$ & $2,105.61$ & $2,104.82$ & 0.79 & \\
\hline & $08 / 03 / 2004$ & $2,104.53$ & $2,104.03$ & 0.50 & \\
\hline & $03 / 02 / 2005$ & $2,104.04$ & $2,103.68$ & 0.36 & \\
\hline & $12 / 21 / 2007$ & $2,102.39$ & $2,102.08$ & 0.31 & \\
\hline & $10 / 19 / 2010$ & $2,099.82$ & $2,100.62$ & -0.80 & \\
\hline & $01 / 27 / 2011$ & $2,099.45$ & $2,100.33$ & -0.88 & 0.65 \\
\hline
\end{tabular}

"Closest measurement to beginning of model simulation. 

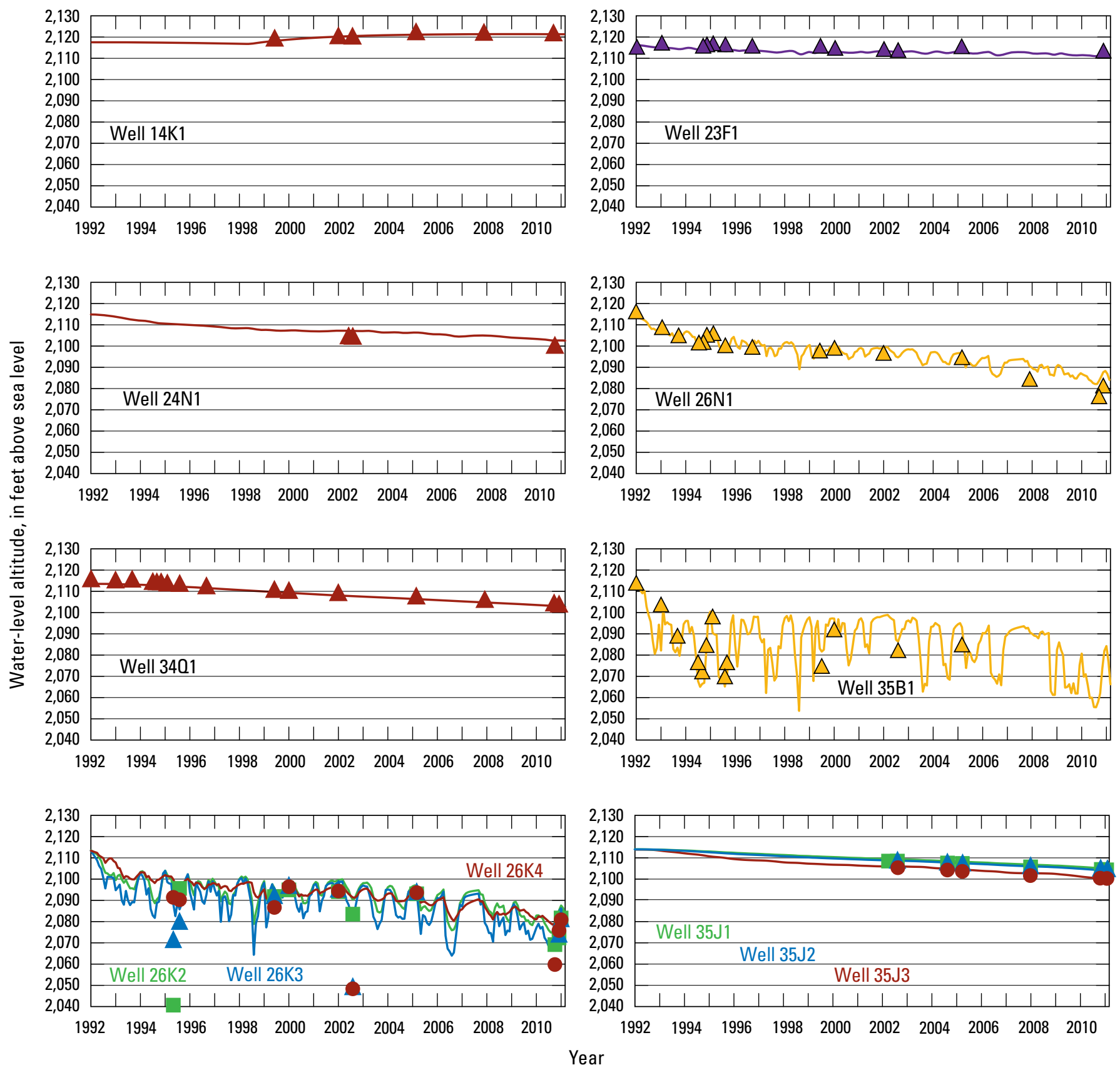

\section{EXPLANATION}
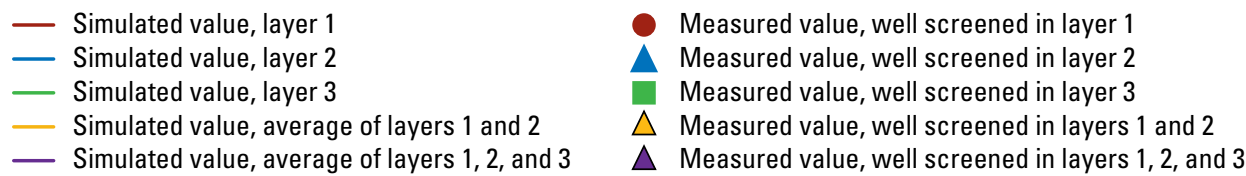

Figure 19. Hydrographs of simulated and measured water levels in 12 wells from predevelopment (1980-88) to January 2011, Langford Basin, Fort Irwin National Training Center, California. 
The simulated hydraulic heads and measured water levels closely match a 1:1 correlation line (fig. 20). A graph of simulated and measured equivalent water levels for an unbiased model ideally should show a random distribution above and below a 1:1 correlation line. The measured and simulated equivalent water levels for the Langford Basin are randomly distributed above and below the 1:1 correlation line except for three values from well 13N/3E-26N1 (three green points in the lower left side of fig. 20). The model overpredicts the three water levels measured from well 13N/3E-26N1 after 2007 (figs. $15 C$ and 20). During the calibration process, adjusting model parameters in the area of well 13N/3E-26N1 did not achieve a better match between the measured and simulated water levels. A process is taking place at this well that is not being simulated by the model.

\section{Model Results}

During the period from April 1, 1992, through December 31, 2010, about 12,320 acre-ft of groundwater were withdrawn from the Langford Basin and about 650 acre-ft recharged (underflow and recharge) the basin (table 5). Because the groundwater withdrawals exceeded recharge, measured and simulated water levels have declined throughout the basin (fig. 18E), more than $30 \mathrm{ft}$ in the area centered around the three production wells. Moreover, simulated outflow through the drain from the Langford Basin began to decrease in 1992 and ceased in 1994 (table 5). In order to meet the groundwater withdrawal demand, a net of about 11,670 acre-ft of water (storage inflow minus storage outflow) was simulated as being removed from groundwater storage within the basin between 1992 and 2010 (table 5).

\section{Model Sensitivity}

The purpose of sensitivity analysis is to quantify the uncertainty in the calibrated model due to uncertainty in the estimates of aquifer parameters, stresses, and boundary conditions (Anderson and Woessner, 1991). The objective is to determine how readily and excessively water-level altitudes are affected by a change in hydrologic parameters in the calibrated model. A sensitivity analysis was conducted for the Langford Basin groundwater-flow model using UCODE-2005 (Poeter and others, 2005). The composite scaled sensitivities (CSS) were used

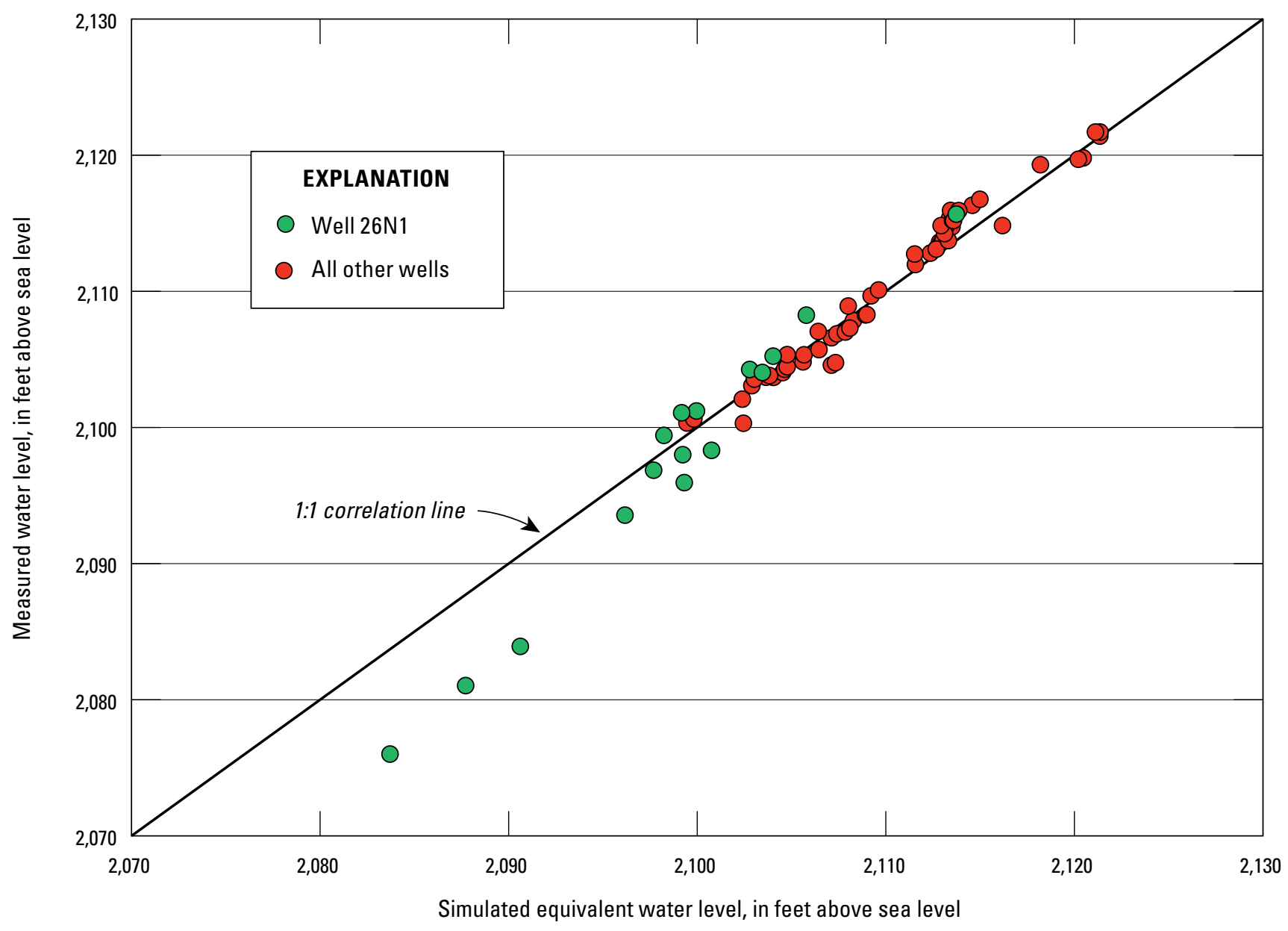

Figure 20. Measured and simulated equivalent water levels, with 1:1 correlation line, for transient conditions, Langford Basin, Fort Irwin National Training Center, California. 
to evaluate the sensitivity of the simulated model parameters. The CSS values can be used to determine if there is sufficient information in the calibration data to estimate a parameter (Hill and Tiedeman, 2007).

CSS values were calculated for 35 parameters as part of the model sensitivity analysis (table 7 and fig. 21). A weighting factor for the observation values was not used in the calculation of the CSS. Hill and Tiedeman (2007) stated that it is likely a parameter-estimation routine will not be able to estimate those parameters whose CSS values are less than about 0.01 times the largest value (here, about 6.5). Therefore, 25 of the 35 parameters estimated for this study are considered sensitive (CSS values greater than 0.065), indicating they can be estimated during the model calibration. The most sensitive parameters (CSS values greater than 2.0) are Sy_Qoa (specific yield, layer 1, Quaternary older alluvium); Kh_Qoa (horizontal hydraulic conductivity, layer 1, Quaternary older alluvium); Sy_Tyg1 (specific yield, layer 1, Tertiary younger sedimentary deposits); Kh_Tyg2 (horizontal hydraulic conductivity, layer 2, Quaternary younger sedimentary deposits); $\mathrm{RCH}_{-} \mathrm{N} 1$ to 76 (groundwater underflow, stress period 1 to 75); and VANI (vertical anisotropy of all model layers).

\section{Limitations of the Model}

A model is only as good as the data used to develop it. The accuracy and reliability of model prediction is related to the quality and distribution of available data. For areas with longterm groundwater development, such as near the Langford
Basin production wells, sufficient data are available to characterize aquifers and to calibrate for water-level variations in time and space. For areas that have limited data, the uncertainty of model predictions is increased. For example, model uncertainty for the southern part of the basin is generally higher than for other simulated areas because almost no data, or only short-term data, are available for this part of the model domain. Similarly, model uncertainty for the deep aquifer of the basin is large because limited data were used to estimate constant hydraulic properties for layer 3 .

As designed and calibrated, the groundwater-flow model of the Langford Basin is best used for analyzing basin-wide issues of water use and supply. The model is particularly useful for estimating changes in regional groundwater levels and flows in response to groundwater extraction. Simulated water levels at locations adjacent to active production wells may not accurately reflect water levels at these locations because simulated water levels are averaged over each model cell and reflect general trends in water levels across a broad area.

Hydraulic properties (hydraulic conductivity, specific yield, and specific storage) were estimated and applied over large areas, owing to the limited areal distribution of groundwaterlevel measurements for use in model calibration. These hydraulic properties represent average values; local hydraulic properties may vary considerably from these average values. These areal average values were sufficient for analyzing the effects of groundwater withdrawals on the aquifer but may not have been adequate for modeling the transport of chemicals. The hydraulic properties need to be updated and refined for the basin as data become available.

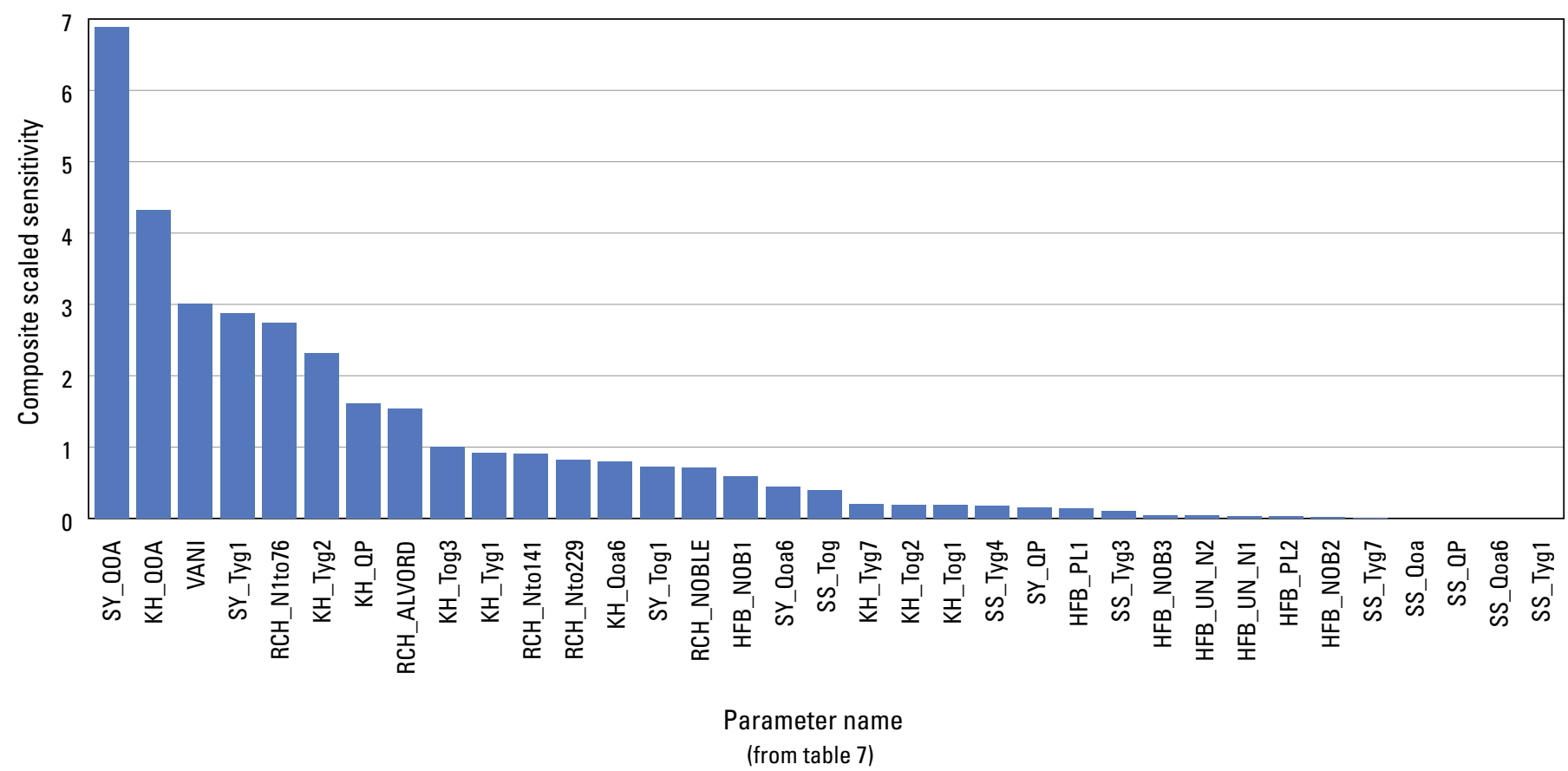

Figure 21. Composite scaled sensitivity values, Langford Basin, Fort Irwin National Training Center, California. 


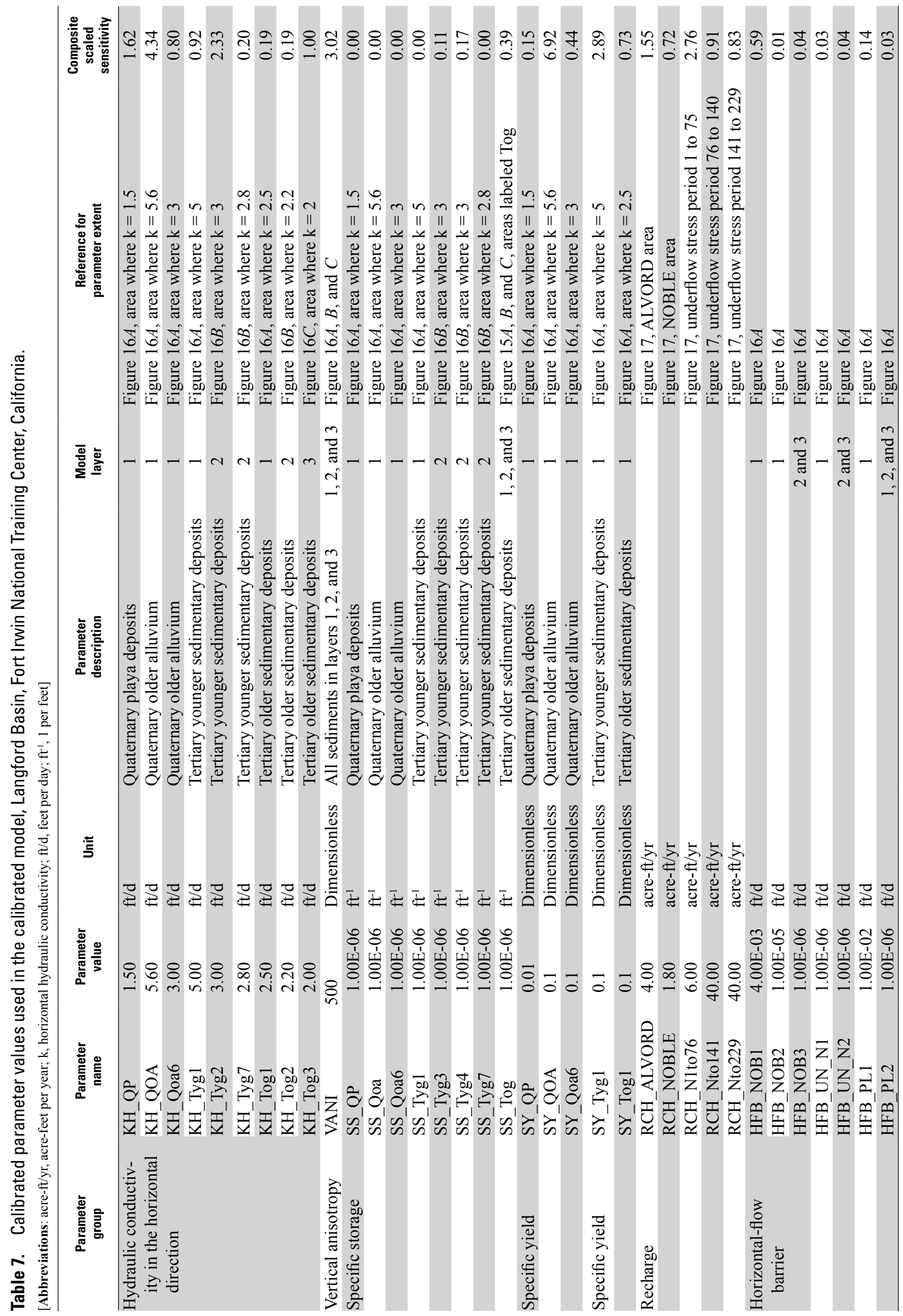


As shown in this report, faults can have a major barrier effect on the flow of groundwater in the study area. Therefore, in order to accurately simulate groundwater flow, the location and hydraulic properties of the faults must be well understood. However, the locations and geometries of faults within the model domain are uncertain because limited data are available for most of the study area. As more information becomes available, the modeled locations of faults may be revised, and additional faults may need to be included in the model.

Limited depth-dependent water-level data is a common problem for many groundwater basins. Existing multiple-well monitoring sites in the basin (fig. 2) provided valuable depthdependent water-level and water-quality information. In 2011, a multiple-well monitoring site was installed in the southern part of the basin (12N/3E-01M1-5), which will provide data for a better understanding of groundwater flow in this area. Additional depth-dependent water-level data are needed in the northern and western parts of the basin. A multiple-well site in the northern part of the basin, near $13 \mathrm{~N} / 3 \mathrm{E}-14 \mathrm{~K} 1$, could be used to help refine the estimate of groundwater underflow from the Irwin Basin to the Langford Basin.

A numerical model is only an approximation of the actual system and is based on average and estimated conditions. The accuracy and the reliability of the model are dependent on the accuracy of the data used to build the model and on the adequacy of the model to simulate the actual system. Despite limitations of the data and of the numerical method, no other approach is better than a groundwater model to integrate a wide variety of data from multiple sources and to develop concepts of a largely unseen system. Groundwater modeling is an iterative process with data and simulation complementing each other. As more data are collected, the model developed for this study could be updated and recalibrated to improve the understanding of the aquifer system.

\section{Simulated Effects of Future Groundwater Withdrawals}

The Fort Irwin NTC is considering various groundwaterwithdrawal scenarios to manage their limited water resources in the Langford Basin. The calibrated Langford Basin groundwater-flow model was used to evaluate changes in groundwater-level altitudes (or water levels) under four different groundwater-withdrawal scenarios being considered by the Fort Irwin NTC for the period of the next 50 years (January 2011 through December 2060).

\section{Description of Model Scenarios}

All the model scenarios use the simulated December 2010 water levels as initial conditions. Groundwater recharge for all the model scenarios was assumed to be the same as the calibrated 2010 conditions (table 5). The quantity of groundwater underflow from the Irwin Basin in future years may be less or more than the 2010 values depending on the water levels in the Irwin Basin. Groundwater underflow out of the basin is head-dependent and was simulated by the groundwater-flow model.

\section{Scenario 1}

Scenario 1 assumes the 2010 annual rate of withdrawals (about 900 acre-ft/yr) remains constant from 2011 to 2060. The monthly distribution of withdrawals was based on the average monthly withdrawals from all production wells in the Irwin, Bicycle, and Langford Basins for the 10-year period 2001-2010 (fig. 22). The monthly groundwater withdrawals for the Langford Basin were calculated by multiplying the 2010 total groundwater withdrawals (about 900 acre-ft/yr) from the Langford Basin by the average 2001-2010 monthly groundwater withdrawal distribution. The distribution of withdrawals for each production well was based on the 2001-2010 withdrawal history of each well. The distribution of withdrawals for each production well (the current name used by Fort Irwin NTC personnel is in parentheses after the State well name) was 15 percent at well 13N/3E-23P1(L-1), 34 percent at well 13N/3E-26K1(L-2), and 51 percent at well 13N/3E-35A1(L-3).

\section{Scenario 2}

Scenario 2 assumes the same rate of withdrawals as in Scenario 1 but assumes the withdrawals will be equally distributed among the three existing wells and two new proposed wells screened in layer 1 that may be constructed in 2016 (the location of the proposed wells is shown on figure $23 B$ ). From January 2011 through December 2015, monthly withdrawal rates and distribution among the three wells calculated for Scenario 1 were used for the three existing Langford wells. From January 2016 through December 2060, the monthly withdrawal rates calculated for scenario 1 were equally distributed among the three existing and two new proposed wells.

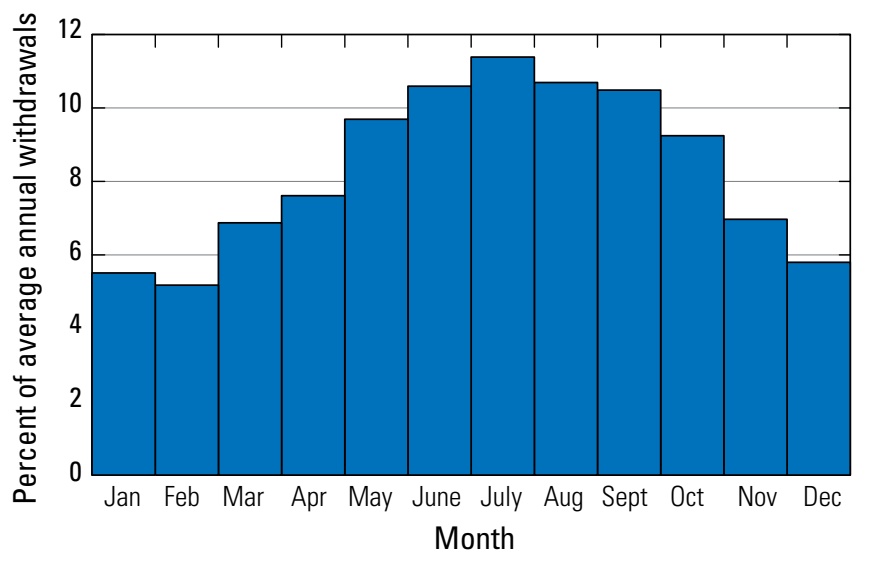

Figure 22. Average 2001 to 2010 monthly groundwater withdrawal distribution for wells in Bicycle, Irwin, and Langford Basins providing water to Fort Irwin National Training Center, California. 


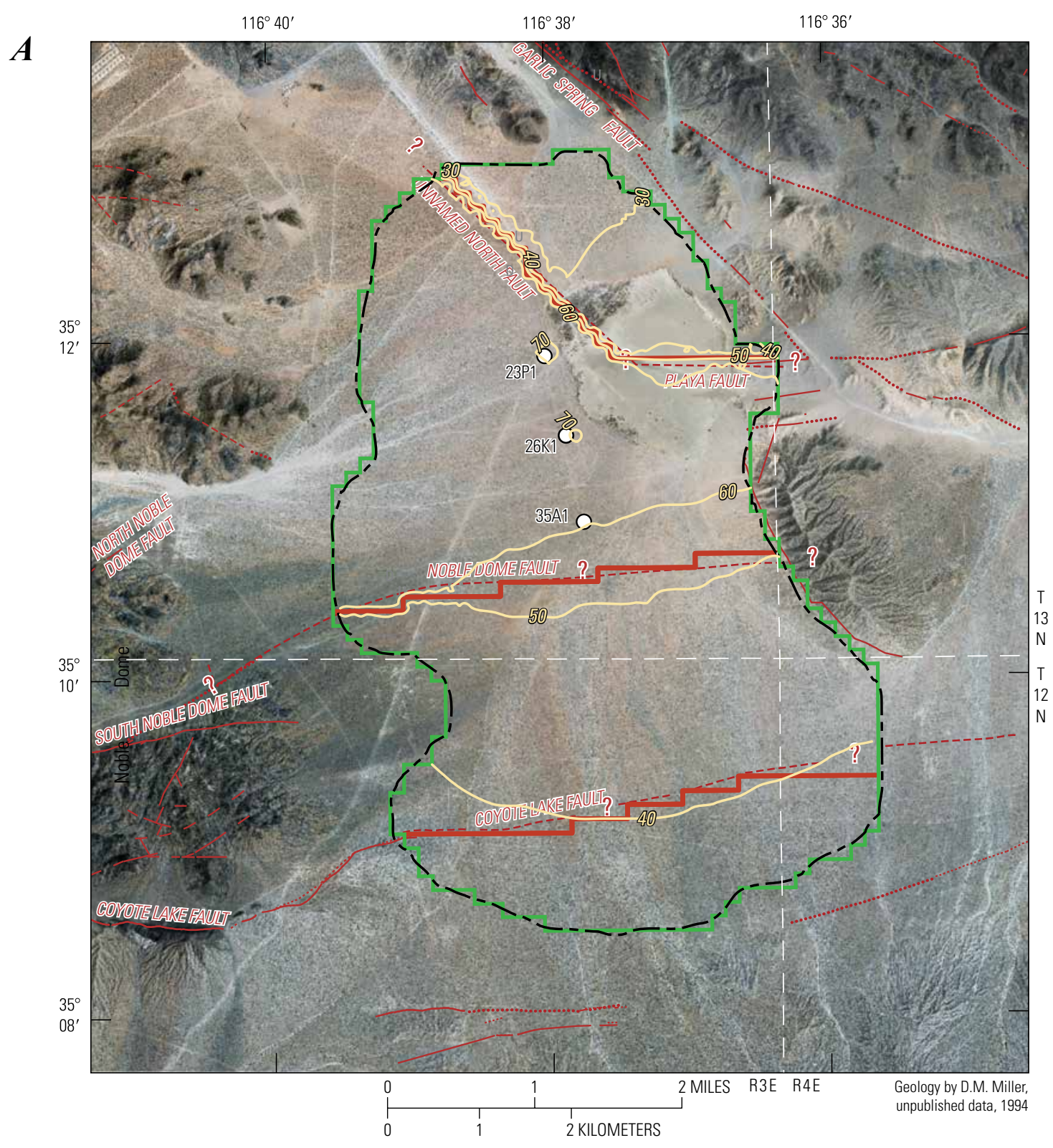

\section{EXPLANATION}

\begin{tabular}{|c|c|}
\hline 10 & Simulated drawdown, in feet \\
\hline & Horizontal-flow barrier \\
\hline & $\begin{array}{l}\text { Approximate groundwater } \\
\text { basin boundary }\end{array}$ \\
\hline ....? & $\begin{array}{l}\text { Fault-Dashed where approximately } \\
\text { located; queried where uncertain; } \\
\text { dotted where concealed }\end{array}$ \\
\hline & Extent of model layer 1 \\
\hline
\end{tabular}

Well and number-Well identified by section number only; township and range is shown on this figure

$$
{ }^{23 P 1} \mathrm{O} \text { Production }
$$

Figure 23. Simulated drawdown from 0 ctober 2010 conditions to 0 ctober 2060 conditions for $A$, scenario $1 ; B$, scenario $2 ; C$, scenario 3; and D, scenario 4, Langford Basin, Fort Irwin National Training Center, California. 


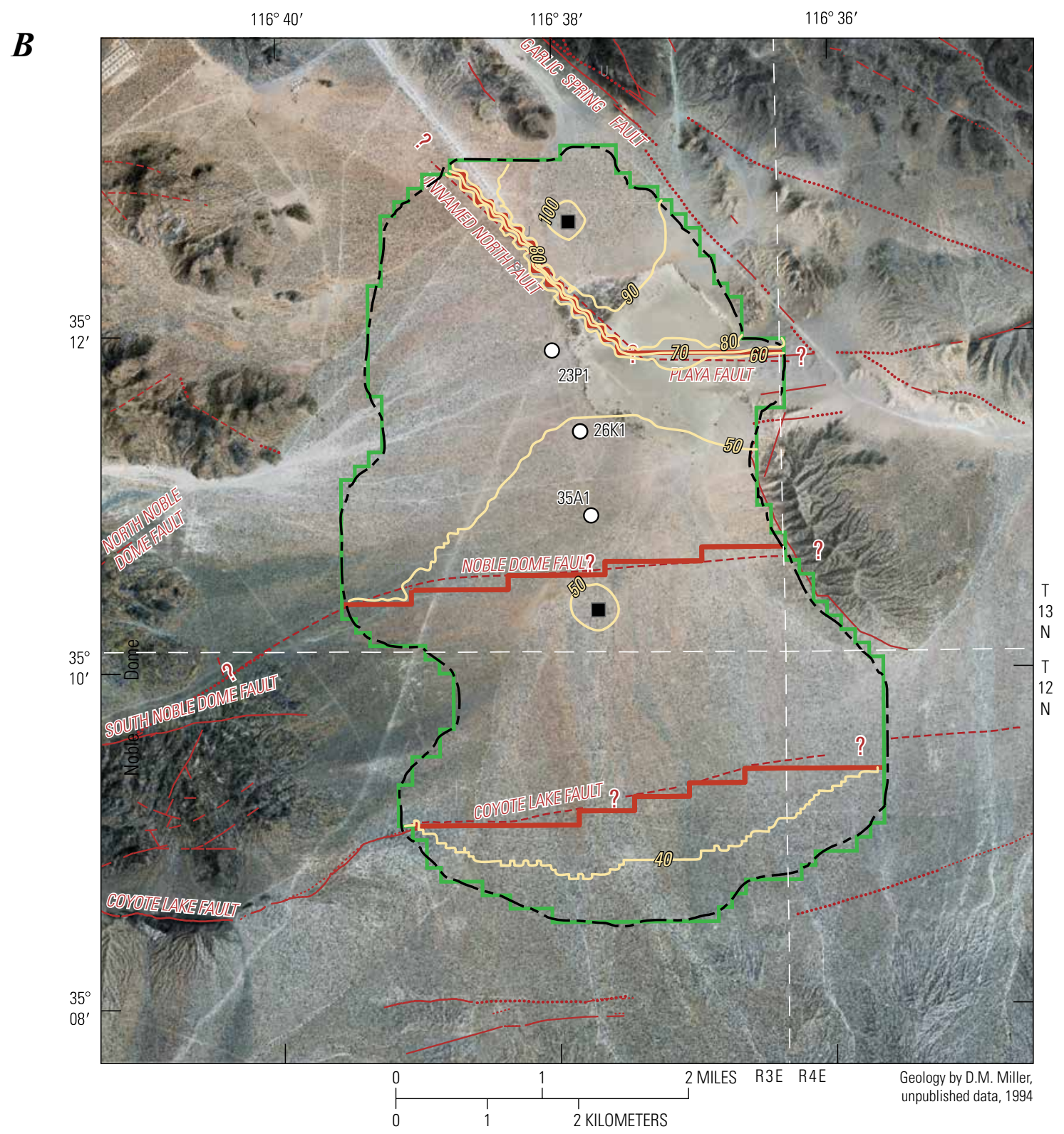

\section{EXPLANATION}

\begin{tabular}{c} 
Simulated drawdown, in feet \\
Horizontal-flow barrier \\
\hline$-\begin{array}{l}\text { Approximate groundwater } \\
\text { basin boundary }\end{array}$ \\
$\begin{array}{c}\text { Fault-Dashed where approximately } \\
\text { located; queried where uncertain; } \\
\text { dotted where concealed }\end{array}$ \\
Extent of model layer 1
\end{tabular}

Well and number-Well identified by section number only; township and range is shown on this figure

$$
\begin{gathered}
\text { 23P1 } O \text { Production } \\
\text { - Proposed }
\end{gathered}
$$
dotted where concealed

Figure 23. Simulated drawdown from October 2010 conditions to 0 ctober 2060 conditions for $A$, scenario 1; $B$, scenario 2; $C$, scenario 3; and $D$, scenario 4, Langford Basin, Fort Irwin National Training Center, California.-Continued 


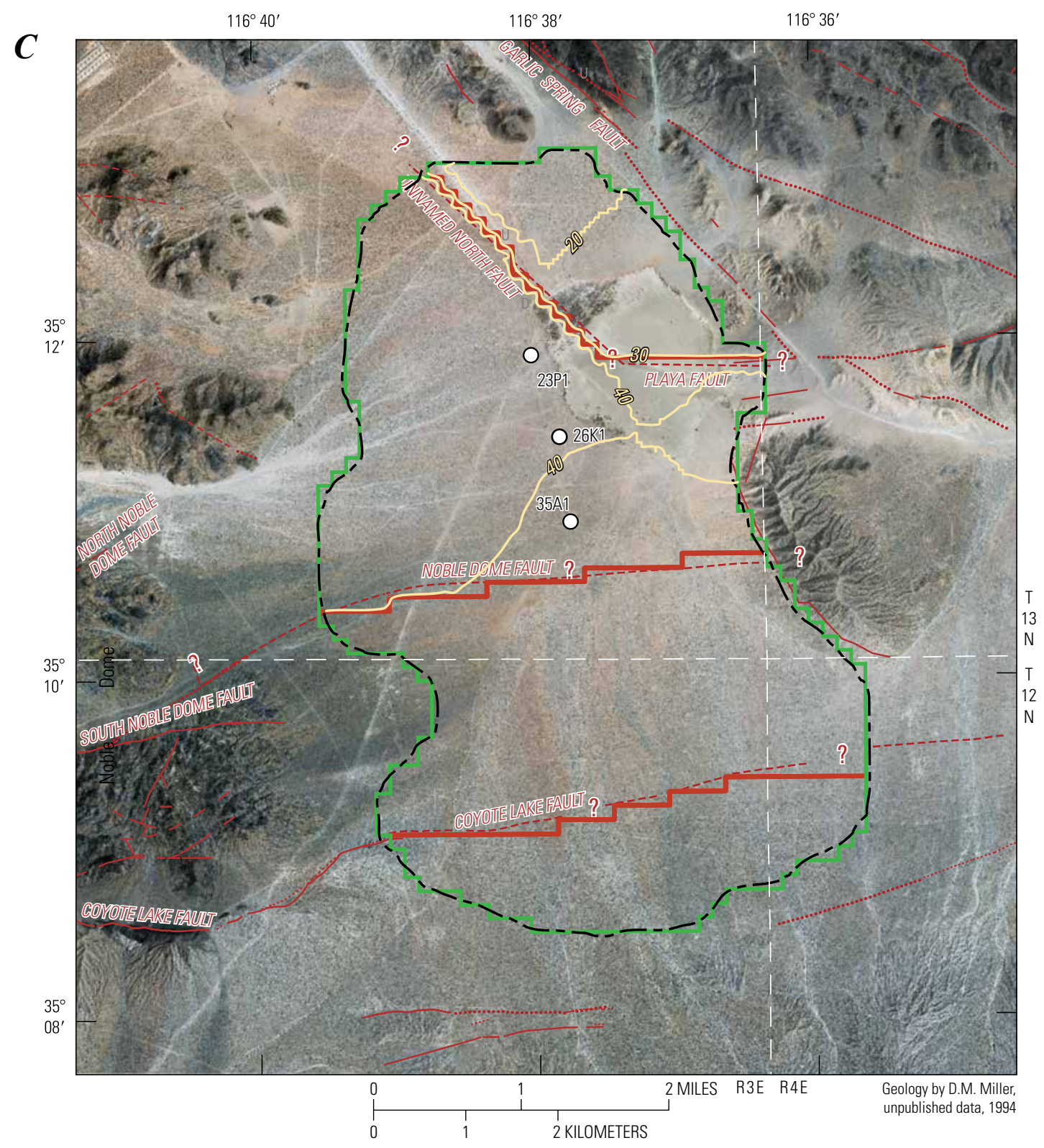

\section{EXPLANATION}

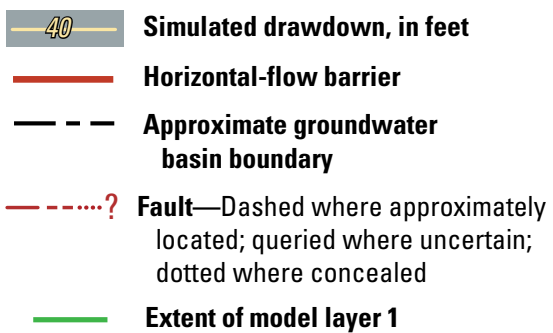
Well and number-Well identified by section number only; township and range is shown on this figure

$$
{ }^{23 \mathrm{P} 1} \mathrm{O} \text { Production }
$$
dotted where concealed

Extent of model layer 1

Figure 23. Simulated drawdown from 0 ctober 2010 conditions to 0 ctober 2060 conditions for $A$, scenario 1; $B$, scenario 2; $C$, scenario 3; and $D$, scenario 4, Langford Basin, Fort Irwin National Training Center, California. 


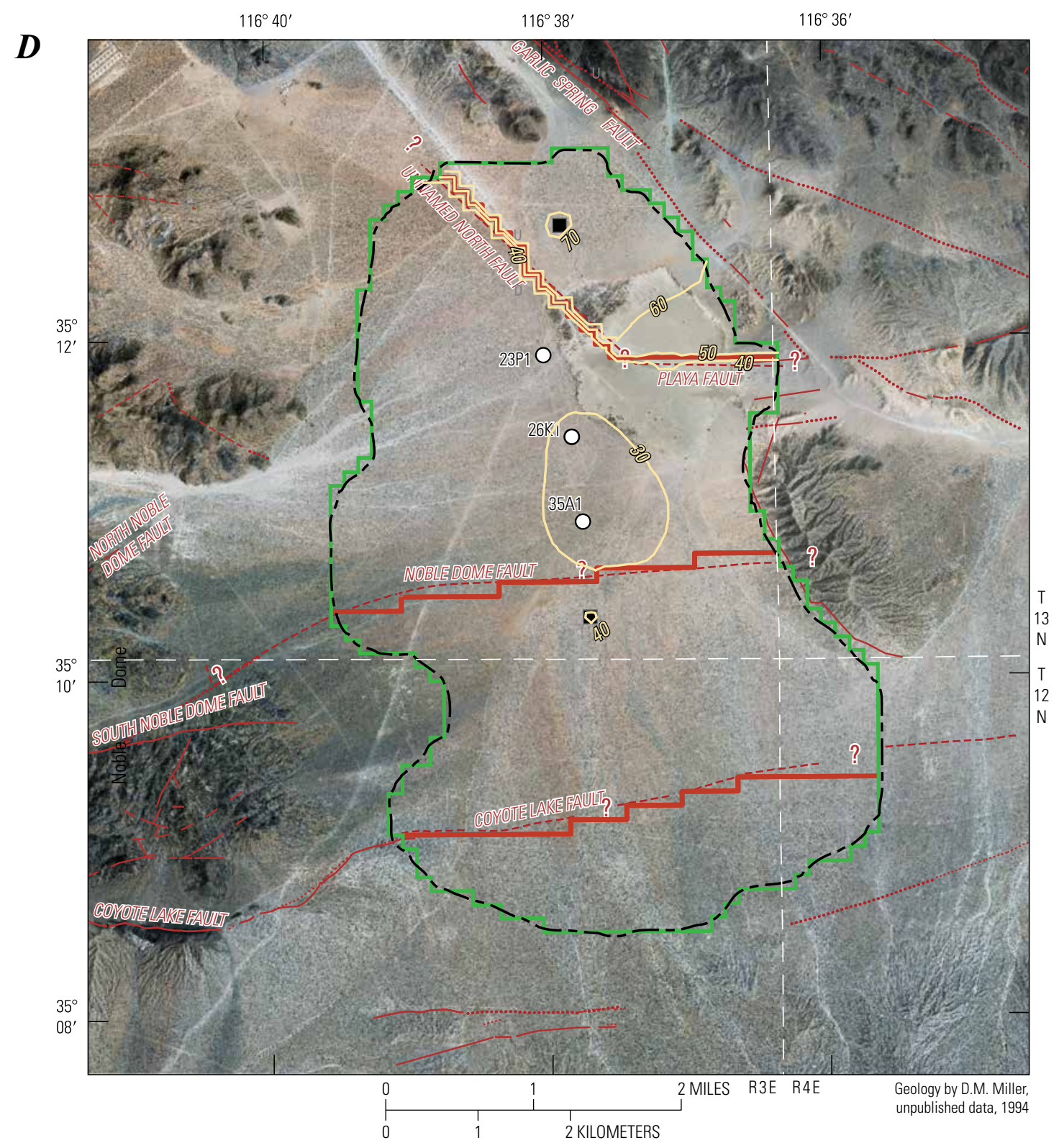

\section{EXPLANATION}

\begin{tabular}{c} 
Simulated drawdown, in feet \\
Horizontal-flow barrier \\
\hline$-\begin{array}{l}\text { Approximate groundwater } \\
\text { basin boundary }\end{array}$ \\
$\begin{array}{l}\text { Fault-Dashed where approximately } \\
\text { located; queried where uncertain; } \\
\text { dotted where concealed }\end{array}$ \\
Extent of model layer 1
\end{tabular}

Well and number-Well identified by section number only; township and range is shown on this figure

$$
\begin{gathered}
\text { 23P1 } \bigcirc \text { Production } \\
\text { 口 Proposed }
\end{gathered}
$$

Figure 23. Simulated drawdown from 0 ctober 2010 conditions to 0 ctober 2060 conditions for $A$, scenario $1 ; B$, scenario $2 ; C$, scenario 3; and $D$, scenario 4, Langford Basin, Fort Irwin National Training Center, California.-Continued 


\section{Scenario 3}

Scenario 3 simulates a reduction of 3 percent per year in the 2010 withdrawal rate for 10 years, from January 2011 through December 2020. The 30-percent reduction in the 2010 withdrawal rate (about 630 acre- $\mathrm{ft} / \mathrm{yr}$ ) is then kept constant until 2060. The monthly distribution of groundwater withdrawals is the same as in Scenario 1, and the 3 percent per year reduction in withdrawals is equally distributed among the three existing Langford wells.

\section{Scenario 4}

Scenario 4 simulates a reduction of 3 percent per year in the 2010 withdrawal rate for 10 years and in withdrawals from two new proposed wells that will be constructed in 2016 . From January 2011 to December 2015, the three existing Langford wells are simulated by using the monthly groundwater withdrawal rates calculated in Scenario 1 with a reduction of 3 percent per year in the 2010 withdrawal rate for these 5 years. From January 2016 to December 2020, the December 2015 withdrawal rate (15 percent of the 2010 withdrawal rate) is reduced by 3 percent per year for 5 years and distributed equally among the three existing wells and two new proposed wells. From January 2021 to December 2060, the 30-percent reduction in the 2010 withdrawal rate (about 630 acre-ft/yr) is then kept constant and distributed equally among the five production wells.

\section{Results of Model Scenarios}

Results of the simulations are presented as drawdown maps for October 2010 to October 2060 for model layer 1 to compare simulated values after the high summer groundwater withdrawals (fig. 23). A positive value for drawdown (as they all are) indicates the simulated hydraulic head has declined from 2010 to 2060. Graphs showing the simulated heads from 1992 to 2060 at selected well locations are presented in figures 24-27 for each of the scenarios. Scenario withdrawals and results are summarized in table 8 .

\section{Scenario 1}

Scenario 1 simulated that the 2010 annual rate of withdrawal (about 900 acre-ft/yr) remained constant from 2011 to 2060 , for a cumulative withdrawal of about 45,000 acre-ft. Continuation of the 2010 withdrawal rate is simulated to result in 60 to $73 \mathrm{ft}$ of drawdown in hydraulic head in the central part of the basin where the three production wells are located and less than $50 \mathrm{ft}$ of drawdown in the northern and southern parts of the basin (fig. $23 \mathrm{~A}$ and table 8 ). These simulated drawdowns are in addition to the decline in water levels that took place from 1992 to 2010, and are referred to in this report as additional drawdown (fig. 18E). Near the production wells, the water-level declines prior to 2011 (20-40 ft) and the simulated drawdown from 2011 to 2060 (about $70 \mathrm{ft}$ ) are projected to decrease the predevelopment saturated thickness of the upper aquifer (layer 1) by about 40 to 45 percent (fig. 24). The simulated drawdown will result in water levels falling below the top of the well screen in all of the production wells (fig. 24).

\section{Scenario 2}

Scenario 2 simulated the same rate of withdrawal as in Scenario 1 but assumes the withdrawals will be equally distributed among the three existing wells and two new proposed wells that will be constructed in 2016 . The cumulative simulated withdrawals were about 45,000 acre- $\mathrm{ft}$ with 28,800 acre-ft of withdrawals occurring in the three existing wells in the central part of the basin and about 8,100 acre-ft of withdrawals occurring in each of the new proposed wells in the northern and southern parts of the basin. Reducing the withdrawals in the central part of the basin by redistributing the 2010 withdrawal rate to two additional pumping wells in 2016 reduces the simulated additional drawdown in the central part of the basin from a range of 60 to $73 \mathrm{ft}$ in Scenario 1 to about 40 to $64 \mathrm{ft}$ in Scenario 2 (fig. $23 A$ and 23B, and table 8). Redistributing withdrawals to the northern and southern parts of the basin results in about $110 \mathrm{ft}$ of additional drawdown at the proposed new well in the north and about $55 \mathrm{ft}$ at the proposed new well in the south (fig. 23B). Redistributing groundwater withdrawals to the northern part of the basin has a large effect on the simulated drawdowns because the area is relatively small and is bounded by low permeability faults. Near the proposed production well in the northern part of the basin, the water-level declines prior to 2011 (about $5 \mathrm{ft}$ ) and the simulated drawdown from 2011 to 2060 (about $110 \mathrm{ft}$ ) are projected to decrease the predevelopment saturated thickness of the upper aquifer (layer 1) by about 60 percent (fig. $25 B$ and table 8). The simulated drawdown will result in water levels falling below the top of the well screen in the proposed new production well in the northern part of the basin (fig. 25B).

\section{Scenario 3}

Scenario 3 simulated a reduction of 30 percent in withdrawals from 2011 to 2020 and then a constant rate from 2021 to 2060. The total volume of simulated groundwater withdrawals was reduced from about 45,000 acre-ft in Scenarios 1 and 2 to about 32,720 acre- $\mathrm{ft}$ in Scenario 3. The simulated reduction in groundwater withdrawals resulted in about $45 \mathrm{ft}$ of additional drawdown in the central part of the basin near the pumping wells compared to about $73 \mathrm{ft}$ in Scenario 1 (fig. $23 A$ and $23 C$, and table 8 ). The reduction in groundwater withdrawals reduced the simulated additional drawdown in the northern and southern parts of the basin by about $10 \mathrm{ft}$ (fig. $23 \mathrm{~A}$, and $23 C$ ). The reduction in groundwater withdrawals, simulated in Scenario 3, would reduce the rate of depletion of the saturated thickness of the upper aquifer compared to Scenario 1 (figs. 24 and 26). 


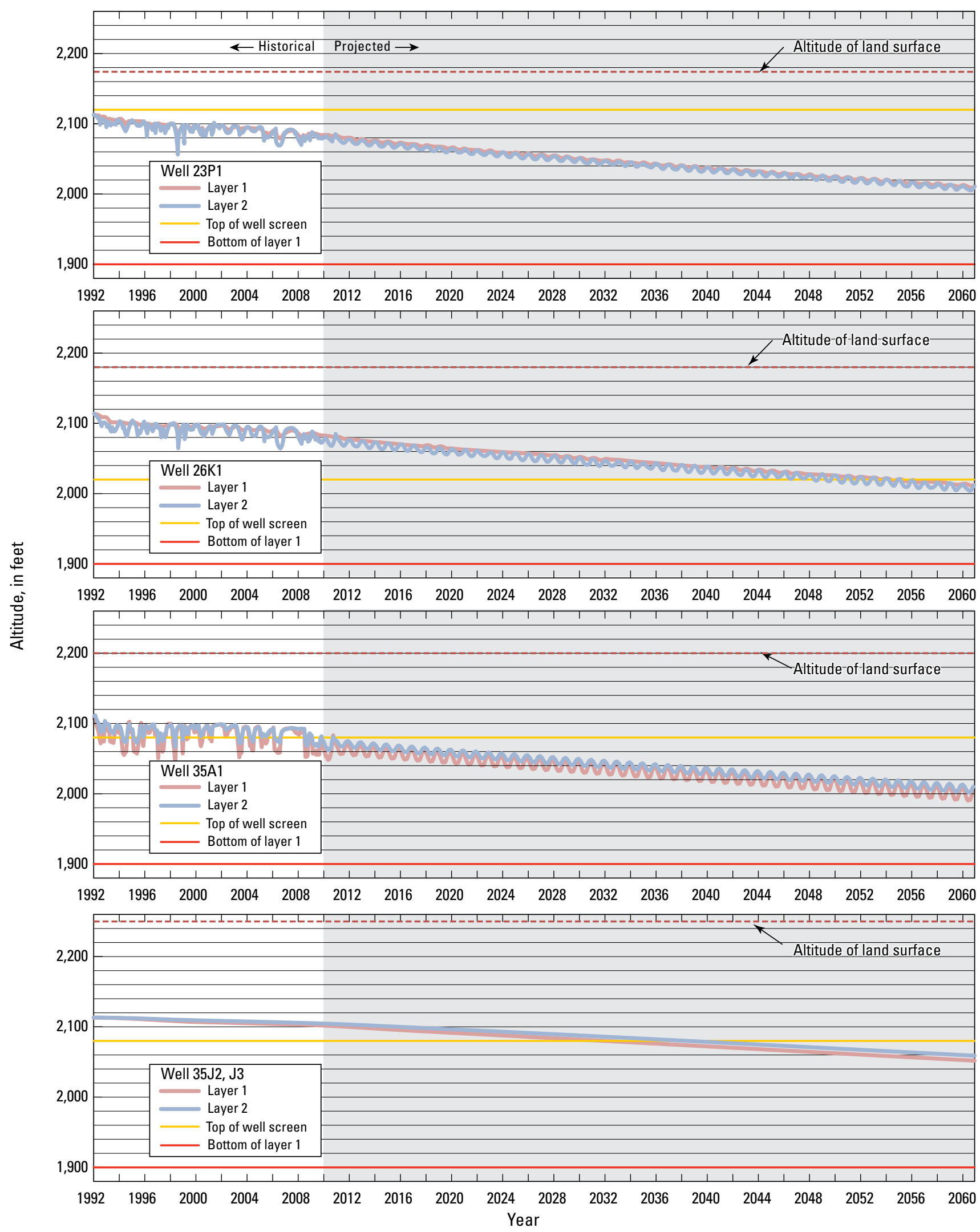

Figure 24. Simulated hydrographs from scenario 1, Langford Basin, Fort Irwin National Training Center, California. 


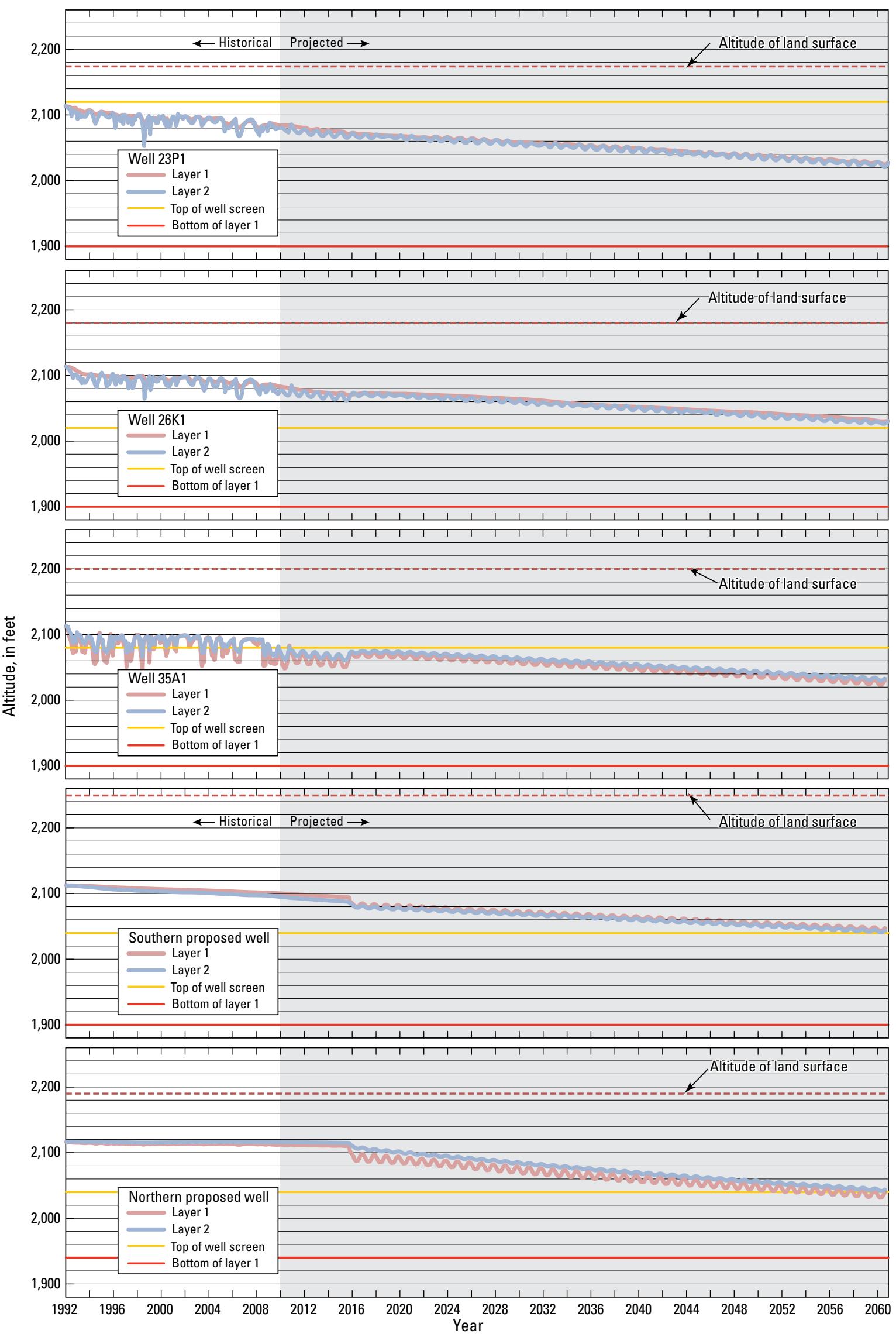

Figure 25. Simulated hydrographs from scenario 2, Langford Basin, Fort Irwin National Training Center, California. 
Table 8. Summary of four model scenarios in the Langford Basin, Fort Irwin National Training Center, California.

[NA, not applicable]

\begin{tabular}{|c|c|c|c|c|c|c|c|c|}
\hline \multirow[b]{2}{*}{$\begin{array}{l}\text { Scenario } \\
\text { number }\end{array}$} & \multirow[b]{2}{*}{$\begin{array}{l}\text { Description } \\
\text { of scenario }\end{array}$} & \multirow[b]{2}{*}{$\begin{array}{l}\text { Figure number } \\
\text { where } \\
\text { drawdown is } \\
\text { shown for } \\
\text { scenario }\end{array}$} & \multirow[b]{2}{*}{$\begin{array}{c}\text { Annual } \\
\text { withdrawal } \\
\text { rate } \\
\text { (acre-feet/year) }\end{array}$} & \multirow[b]{2}{*}{$\begin{array}{l}30 \text { percent } \\
\text { reduced } 2010 \\
\text { withdrawal } \\
\text { rate } \\
\text { (acre-feet/year) }\end{array}$} & \multirow[b]{2}{*}{$\begin{array}{c}\text { Total simulated } \\
\text { groundwater } \\
\text { withdrawals } \\
\text { from January } \\
2011 \\
\text { to December } \\
2060 \\
\text { (acre-feet) }\end{array}$} & \multicolumn{3}{|c|}{ Maximun drawdown (feet) } \\
\hline & & & & & & $\begin{array}{l}\text { Northern part of } \\
\text { basin } \\
\text { (area northeast } \\
\text { of unnamed } \\
\text { fault and } \\
\text { playa fault) }\end{array}$ & $\begin{array}{c}\text { Central part } \\
\text { of basin } \\
\text { (area west of } \\
\text { unnamed fault } \\
\text { and north of } \\
\text { Noble Dome } \\
\text { Fault) }\end{array}$ & $\begin{array}{c}\text { Southern part of } \\
\text { basin } \\
\text { (area south of } \\
\text { Noble Dome } \\
\text { Fault) }\end{array}$ \\
\hline 1 & $\begin{array}{l}2010 \text { annual rate of withdrawal remains } \\
\text { constant from } 2011 \text { to } 2060 \text {. }\end{array}$ & $23 A$ & 900 & NA & 45,000 & 50 & 73 & 51 \\
\hline 2 & $\begin{array}{l}2010 \text { annual rate of withdrawal is equally } \\
\text { distributed among the three existing } \\
\text { wells and two new proposed wells } \\
\text { beginning in January } 2016 \text {. }\end{array}$ & $23 B$ & 900 & NA & 45,000 & 110 & 64 & 55 \\
\hline 3 & $\begin{array}{l}\text { A } 3 \text { percent per year reduction in the } \\
2010 \text { withdrawal rate for } 10 \text { years, from } \\
\text { January } 2011 \text { to December } 2020 \text {. The } \\
30 \text { percent reduced } 2010 \text { withdrawal } \\
\text { rate is then kept constant until } 2060 \text {. } \\
\text { The } 3 \text { percent per year reduction in } \\
\text { withdrawals is equally distributed } \\
\text { among the three existing wells. }\end{array}$ & $23 C$ & $630-873$ & 630 & 32,720 & 28 & 45 & 37 \\
\hline 4 & $\begin{array}{l}\text { From January } 2011 \text { to December } 2015 \text {, } \\
\text { the three existing Langford wells are } \\
\text { simulated using the monthly groundwa- } \\
\text { ter withdrawal rates calculated in Sce- } \\
\text { nario } 1 \text { with a reduction of } 3 \text { percent } \\
\text { per year in the } 2010 \text { withdrawal rate. } \\
\text { From January } 2016 \text { to December } 2020 \text {, } \\
\text { the December } 2015 \text { withdrawal rate ( } 15 \\
\text { percent of the } 2010 \text { withdrawal rate) } \\
\text { is reduced by } 3 \text { percent per year for } 5 \\
\text { years and distributed equally among } \\
\text { the three existing wells and two new } \\
\text { proposed wells. From January } 2021 \\
\text { to } 2060 \text {, the } 30 \text { percent reduced } 2010 \\
\text { withdrawal rate is then kept constant } \\
\text { and distributed equally among the five } \\
\text { production wells. }\end{array}$ & $23 D$ & $630-873$ & 630 & 32,720 & 71 & 40 & 40 \\
\hline
\end{tabular}

\section{Scenario 4}

Scenario 4 simulates a reduction in withdrawals of about 12,280 acre- $\mathrm{ft}$ compared to Scenario 1 and assumes the withdrawals will be equally distributed among the three existing wells and two new proposed wells that will be constructed in 2016, from 2016 to 2060 . The cumulative simulated withdrawals were about 32,720 acre-ft with about 21,270 acre- $\mathrm{ft}$ of withdrawals occurring in the three existing wells in the central part of the basin and about 5,725 acre-ft of withdrawals occurring in each of the new proposed wells in the northern and southern parts of the basin. The combination of reducing and redistributing the cumulative withdrawals resulted in about $40 \mathrm{ft}$ of additional drawdown in the central and southern parts of the basin and about $70 \mathrm{ft}$ in the northern part of the basin (fig. $23 D$ and table 8 ). The results of Scenario 4 show that reducing and redistributing the groundwater withdrawals would maintain the upper aquifer at greater than 50 percent of its predevelopment saturated thickness throughout the groundwater basin (fig. 27). 


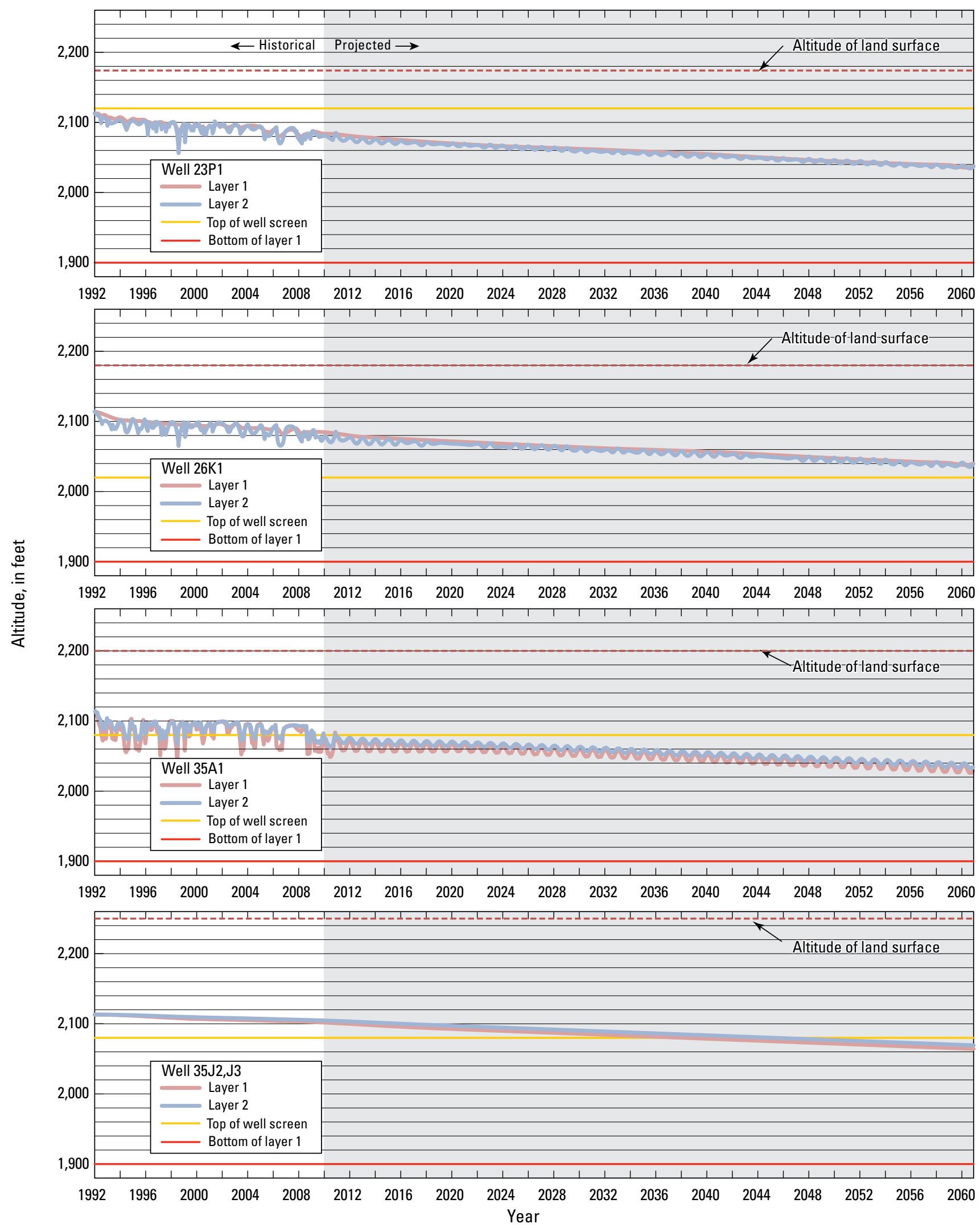

Figure 26. Simulated hydrographs from scenario 3, Langford Basin, Fort Irwin National Training Center, California. 


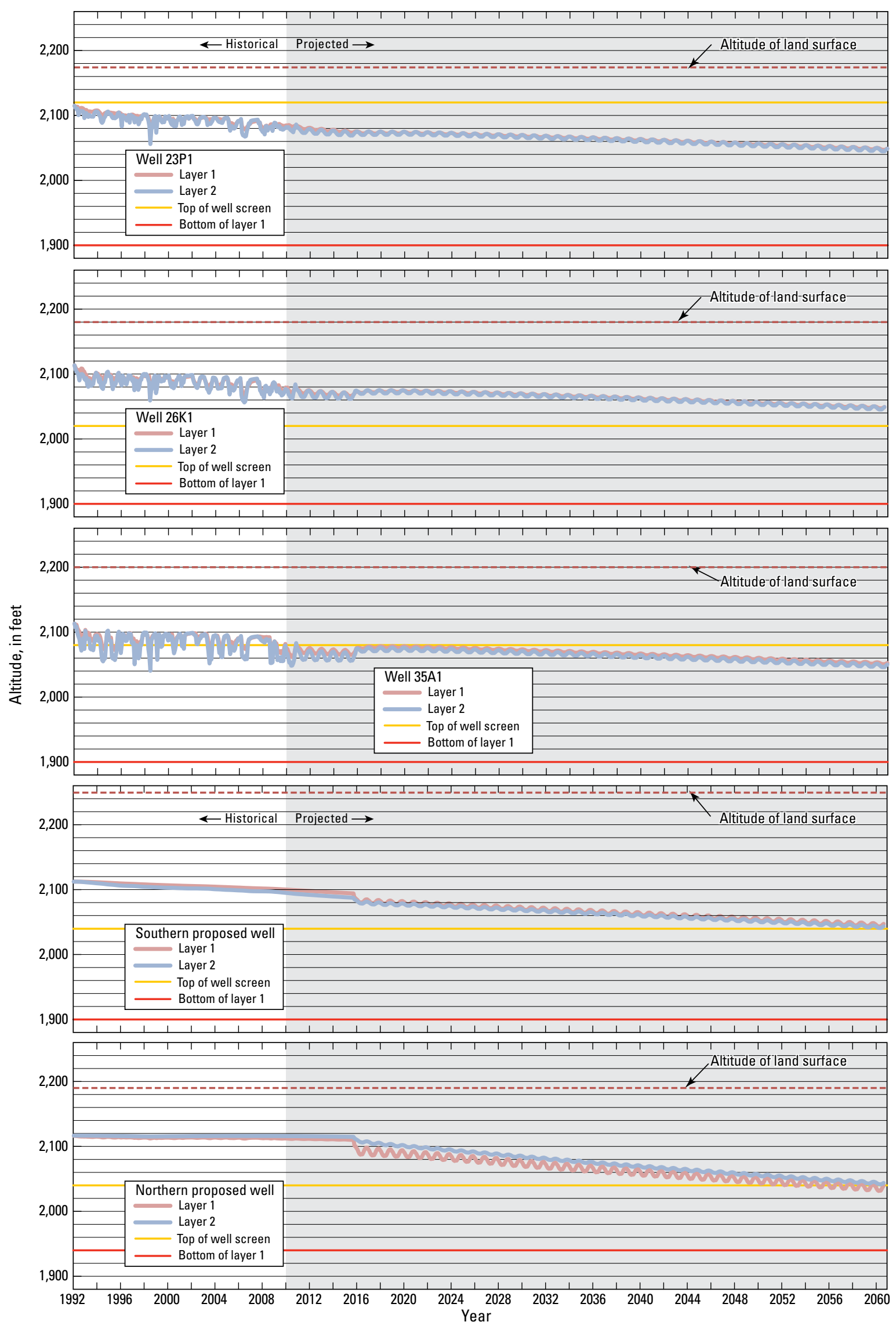

Figure 27. Simulated hydrographs from scenario 4, Langford Basin, Fort Irwin National Training Center, California. 


\section{Summary and Conclusions}

Groundwater withdrawals from the Langford Basin began in April 1992. By the end of December 2010, approximately 12,320 acre-ft of water had been withdrawn from the basin and transported to Irwin Basin. During this period, water levels in the basin decreased by as much as $40 \mathrm{ft}$ and a cone of depression developed around the three production wells.

The USGS collected geohydrologic data to determine the quantity and quality of groundwater available in the basin. Water levels were measured and water-quality samples were collected from existing wells in the basin. Eleven monitor wells also were installed at five sites within the basin. Groundwater quality within the basin was assessed on the basis of collected water-quality samples. Potential sources of poor-quality groundwater also were identified. Geophysical investigations included a gravity survey to determine the altitude of the top of the basement complex, a seismic refraction survey to delineate depths to the Quaternary-Tertiary interface along three transects within the basin, and time-domain electromagnetic induction surveys to map the Quaternary-Tertiary interface and depth to the water table, as well as changes in water salinity with depth. Construction data, lithologic logs, and geophysical logs also were collected for all wells in the basin. On the basis of this information, a hydrogeologic framework for the Langford Basin was developed.

Langford Basin has a relatively flat floor surrounded by generally rugged hills and mountains. The basin has a surface drainage area of about $50 \mathrm{mi}^{2}$, and the floor of the basin covers about $11 \mathrm{mi}^{2}$. The hills and mountains that surround the basin consist of a nearly impermeable complex of pre-Tertiary granitic and metamorphic rocks, referred to as the basement complex. A gravity survey shows there are three deep areas within the Langford Basin where the depth to the basement complex exceeds $1,000 \mathrm{ft}$. The deepest area is beneath Langford Well Lake (dry) playa in the northeastern part of the basin. The other two deep areas are about $1 \mathrm{mi}$ southwest and $2 \mathrm{mi}$ south of the playa. The basin, from bottom to the top, is filled with Tertiary sedimentary deposits, Quaternary-Tertiary older alluvium, and Quaternary younger alluvium. The Tertiary sedimentary deposits, Quaternary-Tertiary older alluvium, and Quaternary younger alluvium form the water-bearing deposits in the Langford Basin. These deposits are unconsolidated at land surface and become semi-consolidated to consolidated with depth.

The Langford Basin aquifer system consists of three aquifers, referred to as the upper aquifer, middle aquifer, and lower aquifer. The upper aquifer is composed of the saturated part of the younger Quaternary alluvium and the Quaternary older alluvium and generally is unconfined. The upper aquifer has a saturated thickness of about $200 \mathrm{ft}$ in the central part of the basin and pinches out at the margins of the basin. The middle aquifer is composed of Tertiary younger sedimentary deposits and generally is confined or partly confined. The middle aquifer is as much as $440 \mathrm{ft}$ thick and is generally less permeable than the upper aquifer. The lower aquifer is composed of
Tertiary older sedimentary deposits, and the thickness ranges from 40 to $1,000 \mathrm{ft}$. The base of the lower aquifer system is considered to be the top of the basement complex.

Data collected for this study, including gravity surveys, water-level measurements, and groundwater-flow model calibration, were used to refine the location of mapped faults and define previously unmapped faults within the Langford Basin. The Garlic Spring Fault is a northwest-southeast trending fault near the northeastern boundary of the basin, where the basement complex is uplifted on the northeast side of the fault. The Noble Dome Fault, an east-west trending fault, is projected to extend from Noble Dome into the Langford Basin, and is a barrier to groundwater flow between the central and southern parts of the basin. The Coyote Lake Fault is an east-west trending fault in the southern part of the basin. The basement complex and Tertiary sedimentary deposits are uplifted on the southern side of the fault. Data are not available to determine if the Coyote Lake Fault is a barrier to groundwater flow. Two additional faults, referred to as the Playa and unnamed north faults, were identified in the northern part of the Langford Basin on the basis of water-level and gravity data. These two faults appear to impede the flow of groundwater between the north and central parts of the basin.

The principal recharge to the Langford Basin is groundwater underflow from the Irwin Basin, which ranged from about 50 acre-ft/yr during pre-development conditions to about $105 \mathrm{acre}-\mathrm{ft} / \mathrm{yr}$ in 1999. Groundwater evapotranspiration by pheatophytes near Garlic Springs probably reduces the quantity of groundwater underflow from the Irwin Basin that recharges the Langford Basin. Because annual precipitation is less than $7 \mathrm{in}$, recharge derived from precipitation is minimal.

Before groundwater development began in 1992, groundwater underflow from the northeastern part of the Langford Basin to the West Cronise Basin was the only discharge from the basin. Evaporation of groundwater beneath Langford Well Lake (dry) playa is negligible because the water table is more than $30 \mathrm{ft}$ below land surface. Prior to 1992, the Langford Basin was considered to be in steady-state conditions with discharge equal to recharge to the basin.

Groundwater withdrawals in Langford Basin began in 1992 when three production wells were constructed in the central part of the basin. Groundwater withdrawn from the wells is transported through a pipeline to Irwin Basin, where it is blended with the water withdrawn from Irwin and Bicycle Basins and is used in the Irwin Basin. None of the water that is withdrawn from Langford Basin is used in or returned to the Langford Basin. Between April 1992 and December 2010, an average of $648 \mathrm{acre}-\mathrm{ft} / \mathrm{yr}$ of water was withdrawn from the Langford Basin.

From 1992 to 2010, approximately 12,310 acre-ft of water were withdrawn from the three production wells in the basin. Groundwater withdrawals have resulted in a cone of depression near production wells in the central part of the basin. From 1992 to 2010, water-level declines were measured at all wells in the Langford Basin, with as much as $40 \mathrm{ft}$ in the cone of depression in the central part of the basin. 
Water-quality samples were collected from 16 wells and 1 spring in Langford Basin during 1993-2010. The predominant ions in the groundwater were $\mathrm{Na}, \mathrm{HCO}_{3}, \mathrm{SO}_{4}$, and $\mathrm{Cl}$. Since the initiation of groundwater withdrawals in 1992, the quality of groundwater at well 13N/3E-35A1 degraded slightly as a result of increasing concentrations of sulfate and chloride. The stable isotopes of oxygen and hydrogen are isotopically lighter than modern-day precipitation and, thus, were recharged under conditions that were cooler than present-day conditions. Analyses of tritium and carbon-14 indicate that most of the groundwater in the basin was recharged prior to 1952 and has an apparent age of 12,500 to 30,000 years.

A transient groundwater-flow model of the Langford Basin that simulates hydrologic conditions from predevelopment to March 2011 was constructed to evaluate current groundwater conditions and to aid in planning to meet future groundwater needs at the base. Measured groundwater-level declines since the initiation of withdrawals were simulated with the calibrated groundwater-flow model. Recharge to the basin is estimated to be about 46 acre-ft/yr, including approximately $6 \mathrm{acre}-\mathrm{ft} / \mathrm{yr}$ of natural recharge derived from precipitation runoff and as much as 40 acre-ft/yr of underflow from the Irwin Basin. This recharge is well below the amount needed to replenish the groundwater being withdrawn from the Langford Basin and results in a simulated net loss of about 11,670 acre- $\mathrm{ft}$ of groundwater storage within the basin.

The calibrated model was used to assess the effect of four groundwater-withdrawal scenarios on the groundwater-flow system in the Langford Basin. The four groundwater-withdrawal scenarios simulate conditions from 1992 to December 2060. Scenario 1 simulated the continuation of the 2010 withdrawal rate in the three existing production wells in the central part of the basin. The continuation of the 2010 withdrawal rate resulted in an additional 70 feet of drawdown in hydraulic head in the central part of the basin where the three production wells are located. Scenario 2 simulated the redistribution of the 2010 withdrawal rate equally to the three existing production wells in the central part of the basin and two new production wells in the northern and southern parts of the basin from 2016 through 2060 . The redistribution of the 2010 withdrawal rate in Scenario 2 resulted in about 10 feet less drawdown in the central part of the basin but about 110 feet of additional drawdown in the new well in the northern part of the basin and about $55 \mathrm{ft}$ of additional drawdown in the new well in the southern part of the basin when compared to scenario 1 results. Scenario 3 simulated reducing the withdrawals from the three existing production wells in the central part of the basin from about 45,000 acre-feet (Scenario 1) to about 32,720 acre-feet. The reduction in withdrawal rate resulted in an additional drawdown of about 45 feet in the central part of the basin near the pumping wells when compared to January 2011 water levels and about 25 feet less than in Scenario 1. Scenario 4 simulates a reduction of 3 percent per year in the 2010 withdrawal rate for 10 years, similar to Scenario 3 and two new proposed wells that will be constructed in 2016. From January 2011 to December 2015, the three existing Langford wells are simulated using the monthly groundwater withdrawal rates calculated in Scenario 1 with a reduction of 3 percent per year in the 2010 withdrawal rate for 5 years . From January 2016 to December 2020, the 3 percent per year reduction in the 2010 withdrawal rate for 5 years is distributed equally among the three existing wells and two new proposed wells. The 30 percent reduced 2010 withdrawal rate (about 630 acre-ft/yr) is then kept constant until 2060 and distributed equally among the five production wells. The combination of reducing and redistributing the cumulative withdrawals resulted in an additional drawdown of about 40 feet in the central and southern parts of the basin and about 70 feet in the northern part of the basin when compared to January 2011 water levels. The results of Scenario 4 show that reducing and redistributing the groundwater withdrawals would maintain the upper aquifer at greater than 50 percent of its predevelopment saturated thickness throughout the groundwater basin.

The groundwater-withdrawal scenarios simulated for this study demonstrate how the calibrated model can be utilized to evaluate the hydrologic factors of different water-management strategies. A simulation-optimization model could be developed to systematically evaluate the hydrologic and economic aspects of different water-management strategies. 


\section{References Cited}

Anderson, M.P., and Woessner, W.W., 1991, Applied groundwater modeling-Simulation of flow and advective transport: San Diego, California, Academic Press, Inc., 381 p.

Berenbrock, Charles, and Schroeder, R.A., 1994, Groundwater flow and quality, and geochemical processes, in Indian Wells Valley, Kern, Inyo, and San Bernardino Counties, California, 1987-88: U.S. Geological Survey WaterResources Investigations Report 93-4003, 59 p.

Beukins, R.P., 1992, Radiometric accelerator mass spectrometry-Background, precision, and accuracy, in Taylor, R.E., Long, Austin, and Kra, R.S., eds., Radiocarbon after four decades-An interdisciplinary perspective: New York, Springer-Verlag, p. 230-239.

Brunt, R., Vasak, L., and Griffioen, J., 2004, Fluoride in groundwater-Probability of occurrence of excessive concentration of global scale: International Groundwater Resources Assessment Centre, UNESCO, Report number SP 2004-2, accessed August 15, 2012, at http://www.un-igrac.org/publications/147\#.

Byers, F.M., Jr., 1960, Geology of the Alvord Mountain quadrangle, San Bernardino County, California: U.S. Geological Survey Bulletin 1089-A, $71 \mathrm{p}$.

California Irrigation Management Information System, 2011, CIMAS Data: California Department of Water Resources, Office of Water Use Efficiency, accessed August 18, 2011, at $h t t p: / / w w w . c i m i s . w a t e r . c a . g o v / c i m i s / d a t a . j s p$.

C.F. Hostrup and Associates, 1955, Water resources survey, Camp Irwin, California: 109 p.

Coplen, T.B., 1994, Reporting of stable hydrogen, carbon, and oxygen isotopic abundances: Pure and Applied Chemistry, v. 66 , p. $273-276$.

Coplen, T.B., Wildman, J.D., and Chen, J., 1991, Improvements in the gaseous hydrogen-water equilibrium technique for hydrogen isotope ratio analysis: Analytical Chemistry, v. 63, p. 910-912.

Craig, Harmon, 1961, Isotopic variation in meteoric waters: Science, v. 133, p. 1702-1703.

Densmore, J.N., 2003, Simulation of ground-water flow in the Irwin Basin aquifer system, Fort Irwin National Training Center, California: U.S. Geological Survey Water-Resources Investigations Report 02-4264, 69 p.
Densmore, J.N., and Bohlke, J.K., 2000, Use of nitrogen isotopes to determine nitrate contamination in two desert basins in California: Interdisciplinary perspectives on drinking water risk assessment and management: Proceedings of the Santiago (Chile) Symposium, September 1998, International Association of Hydrological Sciences Publication no. 260, p. 63-73.

Densmore, J.N., and Londquist, C.J., 1997, Ground-water hydrology and water quality of Irwin Basin at Fort Irwin National Training Center, California: U.S. Geological Survey Water-Resources Investigations Report 97-4092, 159 p.

Donahue, D.J., Linick, T.W., and Jull, A.J.T., 1990, Isotoperatio and background corrections for accelerator mass spectrometry radiocarbon measurements: Radiocarbon, $\mathrm{v}$. 32, book 2, p. 135-142.

Driscoll, F.G., 1986, Groundwater and wells: St. Paul, Minnesota, Johnson Division, p. 168-200.

EarthInfo, Inc., 1995, National Climatic Data Center summary of the day-West 1994: Boulder, Colorado, EarthInfo, Inc., CD-ROM.

EarthInfo, Inc., 2000, EarthInfo CD2 reference manual-for all EarthInfo CD-Rom databases: Boulder, Colorado, EarthInfo, Inc.

Epstein, Samuel, and Mayeda, T.K., 1953, Variation of O-18 content of water from natural sources: Geochimica et Cosmochimica Acta, v. 4, p. 213-224.

Fishman, M.J., ed., 1993, Methods of analysis by the U.S. Geological Survey National Water Quality LaboratoryDetermination of inorganic and organic constituents in water and fluvial sediments: U.S. Geological Survey OpenFile Report 93-125, 217 p.

Fishman, M.J., and Friedman, L.C., eds., 1989, Methods for determination of inorganic substances in water and fluvial sediments: U.S. Geological Survey Techniques of WaterResources Investigations, book 5, chap. A1, 545 p.

Flint, R.F., 1971, Glacial and Quaternary geology: New York, John Wiley and Sons, 892 p.

Fournier, R.O., and Thompson, J.M., 1980, The recharge area for the Coso, California, geothermal system deduced from $\delta \mathrm{D}$ and $\delta^{18} \mathrm{O}$ in thermal and nonthermal waters in the region: U.S. Geological Survey Open-File Report 80-454, 27 p.

Freeze, R.A., and Cherry, J.A., 1979, Groundwater: Englewood, New Jersey, Prentice-Hall, Inc., 604 p.

Friedman, I., Smith, G.I., Gleason, J.D., Warden, A., and Harris, J.M., 1992, Stable isotope composition of waters in southeastern California, 1. Modern precipitation: Journal of Geophysical Research, v. 97, no. D5, p. 5,795-5,812. 
Gagnon, A.R., and Jones, G.A., 1993, AMS-graphite target production methods at the Woods Hole Oceanographic Institution during 1986-1991: Radiocarbon, v. 35, no. 2, p. 301-310.

Garbarino, J.R., 1999, Methods of analysis by the U.S. Geological Survey National Water Quality LaboratoryDetermination of dissolved arsenic, boron, lithium, selenium, strontium, thallium, and vanadium using inductively coupled plasma-mass spectrometry: U.S. Geological Survey Open-File Report 99-93, 31 p.

Gonfiantini, R., 1978, Standards for stable isotope measurements in natural compounds: Nature, v. 271, p. 534-536.

Harbaugh, A.W., 2005, MODFLOW-2005, The U.S. Geological Survey modular ground-water model-The groundwater flow process: U.S. Geological Survey Techniques and Methods, book 6, chap. A16 [variously paged].

Hem, J.D., 1992, Study and interpretation of the chemical characteristics of natural water ( $3 d$ ed.): U.S. Geological Survey Water-Supply Paper 2254, 263 p.

Hill, M.C., and Tiedeman, C.R., 2007, Effective groundwater model calibration, with analysis of data, sensitivities, predictions and uncertainty: New York, John Wiley \& Sons, $455 \mathrm{p}$.

Hsieh, P.A., and Freckleton, J.R., 1993, Documentation of a computer program to simulate horizontal-flow barriers using the U.S. Geological Survey's modular three-dimensional finite-difference ground-water flow model: U.S. Geological Survey Open-File Report 92-477, 32 p.

Izbicki, J.A., Martin, P.M., and Michel, R.L., 1995, Source, movement, and age of ground water in the upper part of the Mojave River Basin, California, U.S.A., in Adar, E.M., and Leibundget, Christian, eds., Application of tracers in arid zone hydrology: International Association of Hydrological Sciences, no. 232, p. 43-56.

Izbicki, J.A., Radyk, J., and Michel, R.L., 2000, Water movement through a thick unsaturated zone underlying an intermittent stream in the Mojave Desert, southern California, USA; Journal of Hydrology, v. 238, no. 3-4, p. 194-217.

Izbicki, J.A., 2004, Source and movement of ground water in the western part of the Mojave Desert, southern California, USA: U.S. Geological Survey Water-Resources Investigations Report 03-4313, $28 \mathrm{p}$.

James M. Montgomery and Associates, 1981, Water supply investigation, Fort Irwin, San Bernardino, California. Phase II, Final report on groundwater basin development and management: Consultant's report prepared for and in the files of the U.S. Army Corps of Engineers [variously paged].
Kalin, R.M., 2000, Radiocarbon dating, in Cook, P.G., and Herczeg, A.L., eds., Environmental tracers in subsurface hydrology: Boston, Massachusetts, Kluewer Academic Publishers, p. 111-144.

Keys, W.S., and MacCary, L.M., 1971, Application of borehole geophysics to water-resources investigations: U.S. Geological Survey Techniques of Water-Resources Investigations Report, book 2, chap. E1, 126 p.

Konikow, L.F., Hornberger, G.Z., Halford, K.J., and Hanson, R.T., 2009, Revised multi-node well (MNW2) package for MODFLOW groundwater-flow model: U.S. Geological Survey Techniques and Methods, book 6, chap. A30, 67 p.

Kunkel, Fred, and Riley, F.S., 1959, Geologic reconnaissance and test-well drilling, Camp Irwin, California: U.S. Geological Survey Water-Supply Paper 1460-F, p. 233-271.

Levy, D.B., Schramke, J.A., Esposito, K.J., Erickson, T.A., and Moore, J.C., 1999, The shallow ground water chemistry of arsenic, fluorine, and major elements-Eastern Owens Lake, California: Applied Geochemistry, v. 14, no. 1, p. 53-65.

McCulloh, T.H., 1960, Geologic map of the Lane Mountain quadrangle, California: U.S. Geological Survey Open-File Report 60-95, scale 1:62,500.

McLain, B.J., 1993, Methods of analysis by the U.S. Geological Survey National Water Quality Laboratory-Determination of chromium in water by graphite furnace atomic absorption spectrophotometry: U.S. Geological Survey Open-File Report 93-449, 16 p.

Michel, R.L., 1976, Tritium inventories of the world oceans and their implications: Nature, v. 263, p. 103-106.

Miller, D.M., Menges, C.M., and Lidke, D.J., 2013, Generalized surficial geologic map of the Fort Irwin area, San Bernardino County, California: in Buesch, D.C., ed., Geology and geophysics applied to groundwater hydrology at Fort Irwin National Training Center, California, U.S. Geological Survey Open-File Report 2013-1024.

Miller, D.M., and Yount, J.C., 2002, Late Cenozoic tectonic evolution of the north-central Mojave Desert inferred from fault history and physiographic evolution of the Fort Irwin area, California: Boulder, Colorado, Geological Society of America Memoir, v. 195, p. 173-197.

Miller, D.M., Yount, J.C., Schermer, E.R., and Felger, T.J., 1994, Preliminary assessment of the recency of faulting at southwestern Fort Irwin, north-central Mojave Desert, California: San Bernardino County Museum Association Special Publications 94-1, p. 41-52. 
Mook, W.G., 1980, The dissolution-exchange model for dating of groundwater with ${ }^{14} \mathrm{C}$, in Fritz, P., and Fontes, J.C., eds., Handbook of environmental isotopes geochemistry: Amsterdam, Elsevier Science Publishing Company, v. 1, p. 50-74.

Morin, R.L., 2000, Basement structure beneath Langford Well Lake Basin, Fort Irwin, California, based on inversion of gravity data: U.S. Geological Survey Open-File Report 00-518, $13 \mathrm{p}$.

Munsell Color, 1975, Munsell soil color charts: Baltimore, Maryland., Munsell Color, Macbeth Division of Kollmorgen Corporation, $27 \mathrm{p}$.

National Oceanic and Atmospheric Administration, 1994, Climatological data, annual summary, California, 1994: Asheville, North Carolina, v. 98, no. 13.

National Oceanic and Atmospheric Administration, 2008, Annual climatological summary, U.S.: National Climatic Data Center, accessed April 3, 2008, at http://www.ncdc.noaa.gov/.

National Research Council, 1947, Report of the subcommitee on sediment terminology: Eos, Transactions, American Geophysical Union, Abstracts, v. 28, no. 6, p. 936-938.

Nishikawa, Tracy, Izbicki, J.A., Hevesi, J.A., Stamos, C.L., and Martin, Peter, 2005, Evaluation of geohydrologic framework, recharge estimates, and ground-water flow of the Joshua Tree area, San Bernardino County, California: U.S. Geological Survey Scientific Investigations Report 2004-5267, 115 p.

Noble, L.F., and Mansfield, G.R., 1922, Nitrate deposits in the Amargosa region, southeastern California: U.S. Geological Survey Bulletin 724, 99 p.

Pagnac, D.C., and Reynolds, R.E., 2006, The fossil mammals of the Barstow Formation, in Reynolds, R.E., ed., Making tracks across the southwest_-The 2006 Desert Symposium: California State University, Desert Studies Consortium and LSA Associates, Inc., p. 65-70.

Patton, C.J., and Kryskalla, J.R., 2003, Methods of analysis by the U.S. Geological Survey National Water Quality Laboratory-Evaluation of alkaline persulfate digestion as an alternative to Kjeldahl digestion for determination of total and dissolved nitrogen and phosphorus in water: U.S. Geological Survey Water-Resources Investigations Report 03-4174, 33 p.

Piper, A.M., 1944, A graphic procedure in the geochemical interpretation of water analyses: American Geophysical Union Transactions, v. 25, p. 914-923.
Poeter, E.P., Hill, M.C., Banta, E.R., Mehl, Steffen, and Christensen, Steen, 2005, UCODE_2005 and six other computer codes for universal sensitivity analysis, calibration, and uncertainty evaluation constructed using the JUPITER API: U.S. Geological Survey Techniques and Methods, book 6, chap. A11, 283 p.

Schermer, E.R., Luyendyk, B.P., and Cisowski, S., 1996, Late Cenozoic structure and tectonics of the northern Mojave Desert: Tectonics, v. 15, no. 5, p. 905-932.

Schneider, R.J., Jones, G.A., McNichol, A.P., von Reden, K.F., Elder, K.L., Huang, Kelan, and Kessel, E.D., 1994, Methods for data screening, flagging, and error analysis at the National Ocean Sciences AMS Facility: Nuclear instruments \& methods in physics research section B-beam interactions with materials and atoms, v. 92, no. 1-4, p. 172-175.

Smith, G.A., 1997, Geometry of Langford Well Lake Basin as estimated by gravity data, Fort Irwin, southern California: San Diego, California, California State University, unpublished Master's Thesis, 29 p.

Stiff, H.A., Jr., 1951, The interpretation of chemical water analysis by means of patterns: Journal of Petroleum Technology, v. 3, no. 10, p. 15-17.

Thatcher, L.L., Janzer, V.J., and Edwards, K.W., 1977, Methods for determination of radioactive substances in water and fluvial sediments: U.S. Geological Survey Techniques of Water-Resources Investigations, book 5, chap. A5, 95 p.

Thomasson, H.G., Jr., Olmsted, F.H., and LeRoux, E.F., 1960, Geology, water resources, and usable ground-water storage capacity of part of Solano County, California: U.S. Geological Survey Water-Supply Paper 1464, 693 p.

U.S. Environmental Protection Agency, 2002, Drinking water standards: accessed September 3, 2002, at http://www.epa.gov/safewater/standards.html.

U.S. Environmental Protection Agency, 2005, Drinking water standards: accessed December 29, 2005, at http://www.epa.gov/safewater/standards.html.

U.S. Geological Survey, 2006, Collection of water samples (ver. 2.0): U.S. Geological Survey Techniques of Water-Resources Investigations, book 9, chap. A4, September 2006, accessed September 24, 2012, at http://pubs.water.usgs.gov/twri9A4/.

U.S. Geological Survey, 2012, East of Langford Well quadrangle, California [map]: Reston, Virginia, U.S. Department of the Interior, 7.5 minute series, scale 1:24,000.

U.S. Geological Survey, 2012, Langford Well quadrangle, California [map]: Reston, Virginia, U.S. Department of the Interior, 7.5 minute series, scale 1:24,000. 
Vogel, J.S., Nelson, D.E., and Southon, J.R., 1987, ${ }^{14} \mathrm{C}$ background levels in an accelerator mass spectrometry system: Radiocarbon, v. 29, no. 3, p. 323-333.

Welch, A.H., Westjohn, D.B., Helsel, D.R., and Wanty, R.B., 2000, Arsenic in ground water of the United States: Occurrence and geochemistry: Ground Water, v. 38, no. 4, p. 589-604.

Wilde, F.D., Radtke, D.B., Gibs, Jacob, and Iwatsubo, R.T., eds., 2004 with updates through 2009, Processing of water samples (ver. 2.2): U.S. Geological Survey Techniques of Water-Resources Investigations, book 9, chap. A5, April 2004, accessed September 24, 2012, at http://pubs.water.usgs.gov/twri9A5/.

Wilson F. So and Associates, Inc., 1989, U.S. Army National Training Center at Fort Irwin, California, water basin development plan, final report: Consultant's report prepared for and in the files of the Commander of the National Training Center at Fort Irwin, $85 \mathrm{p}$.

Wilson, J.D., and Naff, R.L., 2004, The U.S. Geological Survey modular ground-water model - GMG linear equation solver package documentation: U.S. Geological Survey Open-File report 2004-1261, 47 p.

$1261,47 \mathrm{p}$.

Yount, J.C., Schermer, E.R., Felger, T.J., Miller, D.M., and Stephens, K.A., 1994, Preliminary geologic map of Fort Irwin Basin, north-central Mojave Desert, California: U.S. Geological Survey Open-File Report 94-173, 27 p. 


\section{Appendix 1}

\section{Lithologic Logs}

The U.S. Geological Survey (USGS) established five single- or multiple-well monitoring sites in Langford Basin. Lithologic logs were compiled for each well on the basis of observations recorded during drilling and analysis of drill cuttings collected from the borehole. Cuttings, collected at 20 -ft intervals, were described by rock type, texture, sorting, rounding, color, mineralogy, and any other identifying characteristics. Texture descriptions follow the National Research Council (1947) grain-size classification, which allows for correlation of general grain-size terms to size limits, in millimeters or inches. Color, determined on moist samples, follows the numerical code designations in the Munsell Soil Color Charts (Munsell Color, 1975).

Similar lithologic units, determined from the detailed lithologic logs, were grouped to facilitate compilation of generalized lithologic columns (figs. A-1-A-5). Depths of contacts between lithologic units were determined by use of borehole geophysical logs.

\section{Borehole Geophysics}

Geophysical logs were run at each borehole immediately after completion of drilling. The logs of the uncased boreholes, which were filled with drilling mud, included 16-in. and 64-in. normal resistivity, lateral (6-ft) resistivity, spontaneous potential (SP), natural gamma, and caliper logs (figs. A-1-A-5). These logs provide information on the characteristics of the formations and on the presence and quality of groundwater. Data from the geophysical logs were used in conjunction with the lithologic logs to determine the placement of piezometers at the three multi-well monitoring sites.
Resistivity devices measure the evident resistivity of a volume of rock under the direct application of an electric current (Keys and MacCary, 1971). Resistivity generally is correlated to grain size. Low resistivity generally indicates the presence of fine-grained deposits, such as silt, clay, and shale; high resistivity indicates the presence of coarse-grained materials, such as sand and gravel.

SP devices measure voltage differences between the borehole fluid and the surrounding rock (Keys and MacCary, 1971). SP logs mainly are used for correlating geologic units, determining bed thickness, and differentiating between nonporous and porous beds. SP logs generally have a baseline corresponding to impermeable beds, such as clay or shale. Where formation water is less resistive than the drilling mud (more saline), deflections to the left of the baseline correspond to permeable strata; the opposite is true where formation water is more resistive than the drilling mud.

Natural gamma logs measure the intensity of gamma-ray emissions resulting from the natural decay of potassium- 40 and of the daughter products of uranium and thorium. Gamma logs primarily are used as indicators of lithology and for geologic correlation. Higher-intensity gamma rays generally are emitted by clay and feldspar-rich gravel and granite (Driscoll, 1986). At the Fort Irwin National Training Center, an increase in gamma intensity generally is interpreted as corresponding to an increase in granitic materials in the deposits.

Caliper devices measure the diameter of the borehole. The caliper log can indicate "cave-in" in unconsolidated sand or constriction due to swelling clay. 


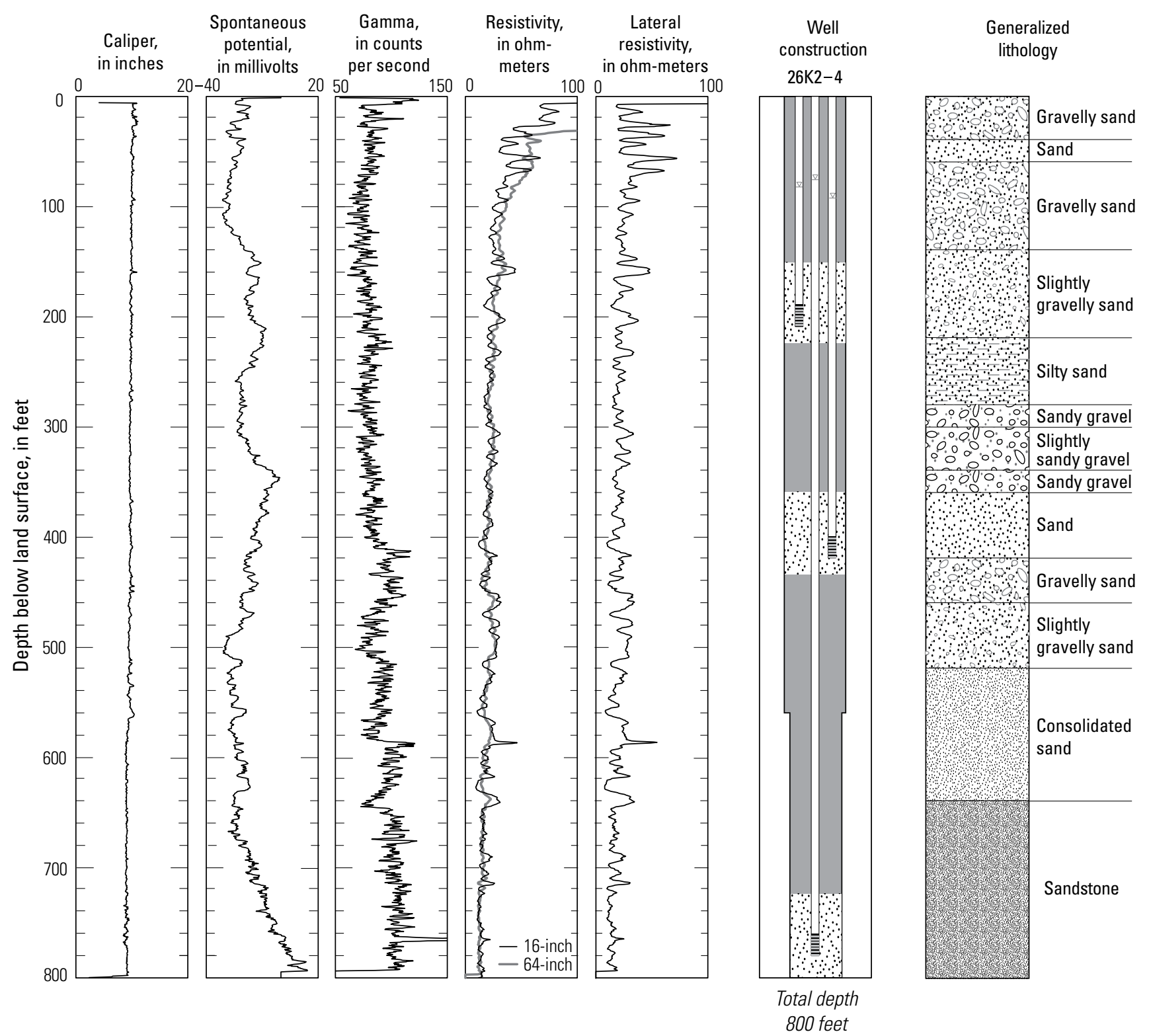

Figure A1-1. Geophysical logs, well-construction diagram, and stratigraphic column for the borehole of monitoring site drilled in Langford Basin at Fort Irwin National Training Center, California: LL1 (13N/3E-26K2-4). 


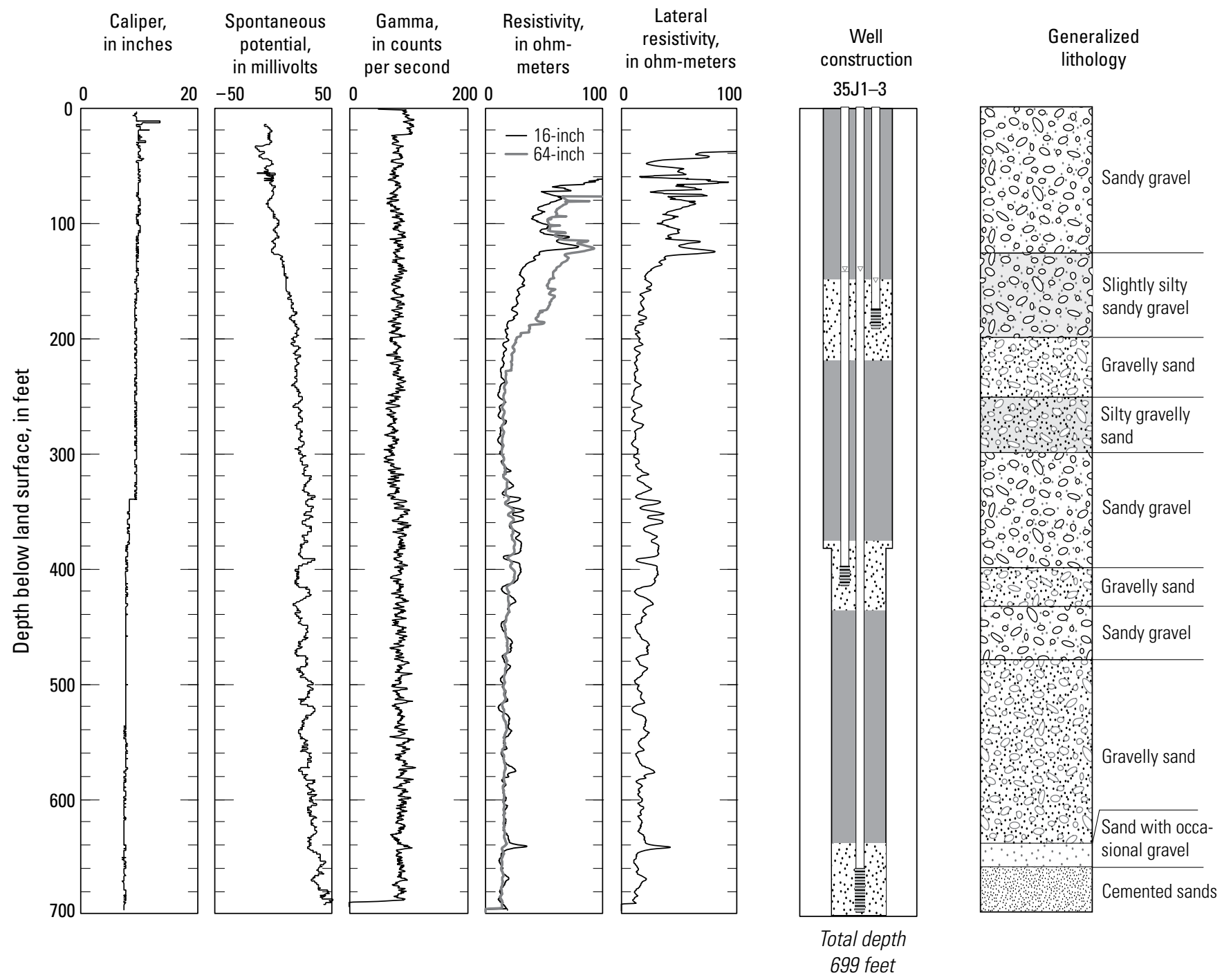

Figure A1-2. Geophysical logs, well-construction diagram, and stratigraphic column for borehole of monitoring site drilled in Langford Basin at Fort Irwin National Training Center, California: LL2 (13N/3E-35J1-3). 


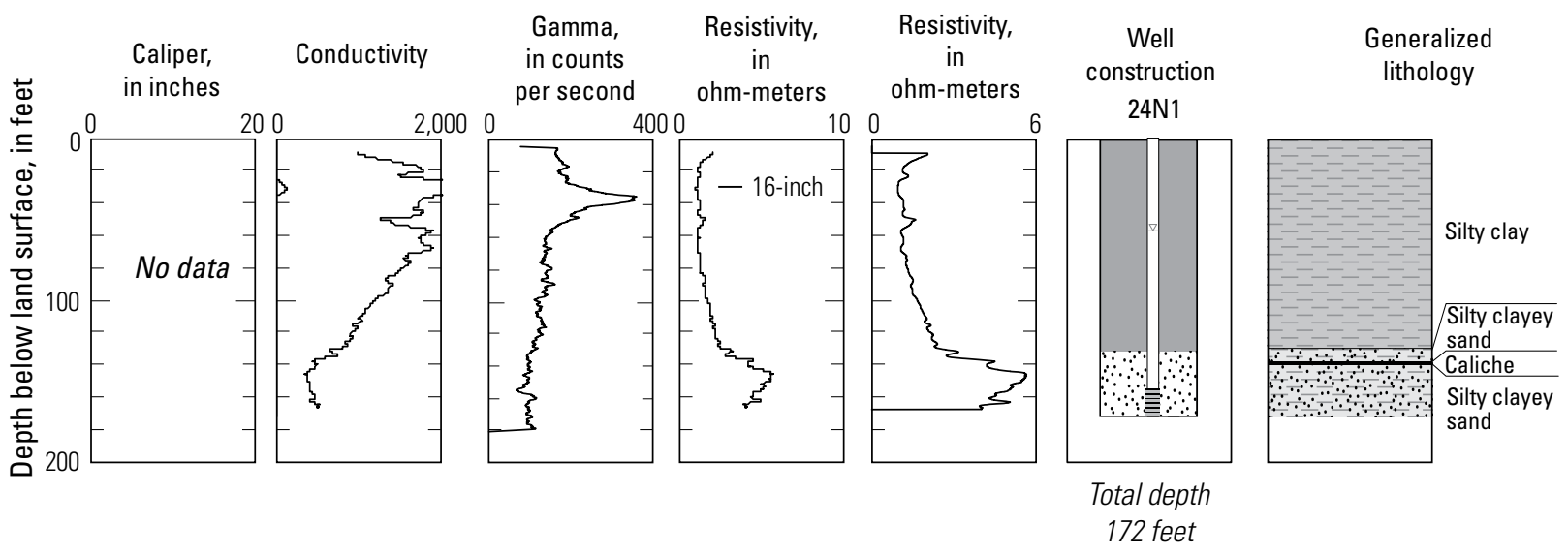

Figure A1-3. Geophysical logs, well-construction diagram, and stratigraphic column for borehole of monitoring site drilled in Langford Basin at Fort Irwin National Training Center, California: LL3 (13N/3E-24N1).

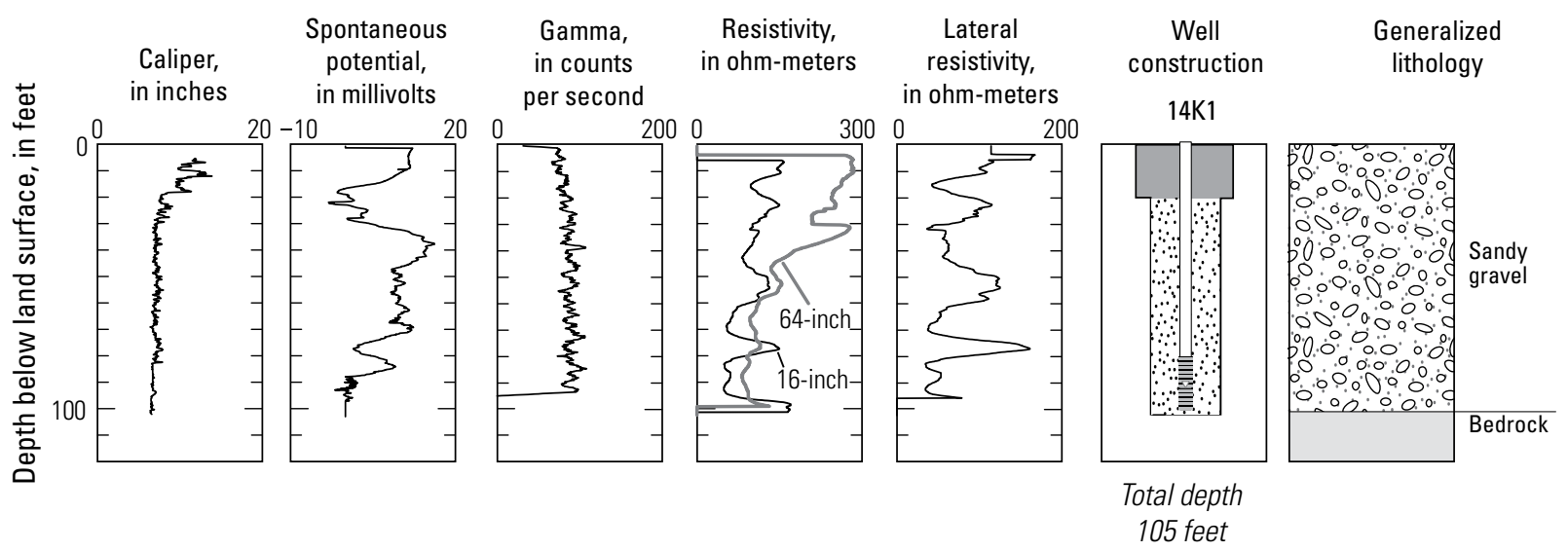

Figure A1-4. Geophysical logs, well-construction diagram, and stratigraphic column for borehole of monitoring site drilled in Langford Basin at Fort Irwin National Training Center, California: LW1 (13N/3E-14K1). 


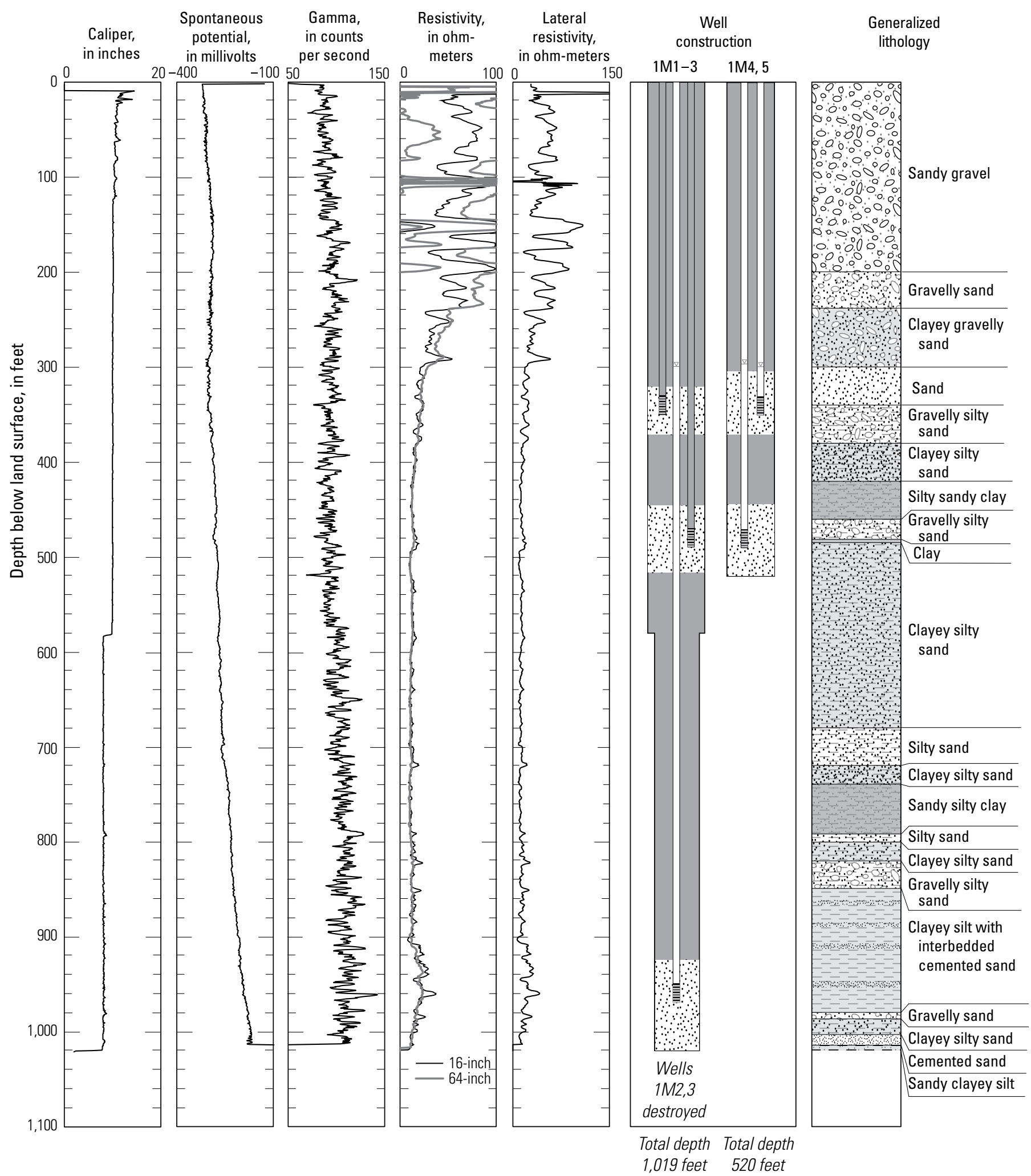

Figure A1-5. Geophysical logs, well-construction diagram, and stratigraphic column for borehole of monitoring site drilled in Langford Basin at Fort Irwin National Training Center, California: LL04B (12N/3E-1M4 and 5) and LL04 (12N/3E-1M1-3). 


\section{Appendix 2}

Water-quality data for selected wells and a spring in Langford Basin, Fort Irwin National Training Center, California, 1955-2011. See following page. 
Appendix 2. Water-quality data for selected wells and a spring in Langford Basin, Fort Irwin National Training Center, California, $1955-2011$.

[State Well-Numbering System, see in text. Abbreviations: AL-US, U.S. Environmental Protection Agency (USEPA) action level; CaCO, calcium carbonate; E, estimated; HAL-US, USEPA lifetime health advisory level; $\mathrm{M}$, presence verified but not quantified; MCL-US, USEPA maximum contaminant level; na, not available; $\mathrm{NH}_{4}$, ammonium; $\mathrm{NL}^{-\mathrm{CA}}$, California Department of Public Health (CDPH) notification level; mg/L, milligrams per liter; pCi/L, picocuries per liter; per mil, parts per thousand; $\mathrm{R}$, radchem non-detect, below ssLc; $\mathrm{SiO}{ }_{2}$, silicon dioxide; SMCL-CA, CDPH maximum contaminant level; TU, tritium units; $\mu \mathrm{g} / \mathrm{L}$, micrograms per liter; $\mu \mathrm{S} / \mathrm{cm}$, microsiemens per centimeter at 25 degrees Celsius $\left({ }^{\circ} \mathrm{C}\right)$;

$<$, actual value is less than value shown; - , no data]

\begin{tabular}{|c|c|c|c|c|c|c|c|c|}
\hline $\begin{array}{l}\text { State } \\
\text { well } \\
\text { number }\end{array}$ & $\begin{array}{l}\text { Local } \\
\text { well } \\
\text { name }\end{array}$ & $\begin{array}{l}\text { Station } \\
\text { number }\end{array}$ & Date & $\begin{array}{c}\text { Temperature, } \\
\text { air } \\
\left({ }^{\circ} \mathrm{C}\right)\end{array}$ & $\begin{array}{l}\text { Depth to } \\
\text { water level, } \\
\text { feet below } \\
\text { land surface }\end{array}$ & $\begin{array}{c}\text { Dissolved } \\
\text { oxygen, } \\
\text { water, } \\
\text { unfiltered } \\
\text { (mg/L) }\end{array}$ & $\begin{array}{l}\text { pH, water, } \\
\text { unfiltered, } \\
\text { field } \\
\text { (standard units) }\end{array}$ & $\begin{array}{c}\text { pH, water, } \\
\text { unfiltered, } \\
\text { laboratory } \\
\text { (standard units) }\end{array}$ \\
\hline MCL & & & & na & na & na & na & na \\
\hline 012N003E01M001S & LL04-1 & 350929116372301 & $08 / 02 / 2011$ & 28.5 & - & 0.7 & 8.8 & 8.1 \\
\hline 013N003E11NS01S & Garlic Spring & 351348116382701 & 06/30/1993 & 35.5 & - & - & 8.9 & 9.1 \\
\hline 013N003E23F001S & LX-1 & 351226116380401 & $10 / 09 / 1980$ & - & - & - & - & 8.3 \\
\hline 013N003E23F001S & - & 351226116380401 & $11 / 19 / 1986$ & - & - & - & - & 8.3 \\
\hline 013N003E23P001S & LP-3 & 351154116380101 & $10 / 20 / 1980$ & - & - & - & - & 7.8 \\
\hline 013N003E23P001S & - & 351154116380101 & $11 / 19 / 1986$ & - & - & - & - & 7.8 \\
\hline 013N003E26K001S & LP-2 & 351125116374901 & 04/03/1989 & - & - & - & - & 8.3 \\
\hline 013N003E26K001S & - & 351125116374901 & $04 / 20 / 1993$ & - & - & - & - & 8.3 \\
\hline 013N003E26K001S & - & 351125116374901 & 05/20/1993 & - & - & - & 8.3 & 8.3 \\
\hline 013N003E26K001S & - & 351125116374901 & 06/24/1999 & - & - & 2.0 & 8.2 & 8.2 \\
\hline 013N003E26K001S & - & 351125116374901 & $05 / 12 / 2011$ & 22.5 & - & 1.8 & 8.3 & 8.4 \\
\hline 013N003E26K002S & LL1-780 & 351128116374701 & 08/03/1999 & 38.9 & - & 0.4 & 9.1 & 9.1 \\
\hline 013N003E26K002S & - & 351128116374701 & $07 / 26 / 2000$ & 40.5 & - & 0.3 & 9.3 & 9.1 \\
\hline 013N003E26K002S & - & 351128116374701 & $11 / 02 / 2011$ & 19.5 & - & 9.4 & 9.5 & 9.2 \\
\hline 013N003E26K003S & LL1-420 & 351128116374702 & 06/25/1999 & - & - & $<0.2$ & 8.1 & 8.2 \\
\hline 013N003E26K003S & - & 351128116374702 & $07 / 27 / 2000$ & 36.0 & - & - & 8.4 & 8.3 \\
\hline 013N003E26N002S & TH-8 & 351106116382801 & $04 / 13 / 1988$ & - & - & - & - & 8.6 \\
\hline 013N003E26N002S & - & 351106116382801 & 07/30/1993 & 32.0 & 159.09 & - & 8.0 & 8.0 \\
\hline 013N003E34Q001S & TH-10 & 351020116385101 & $04 / 13 / 1988$ & - & - & - & - & 6.2 \\
\hline 013N003E35A001S & LP-1 & 351054116373801 & 04/17/1989 & - & - & - & - & 8.6 \\
\hline 013N003E35A001S & - & 351054116373801 & $04 / 20 / 1993$ & - & - & - & - & 8.8 \\
\hline 013N003E35A001S & - & 351054116373801 & 06/24/1999 & - & - & 2.6 & 8.6 & 8.5 \\
\hline 013N003E35A001S & - & 351054116373801 & $12 / 07 / 2011$ & 9.0 & - & 5.1 & 8.6 & 8.6 \\
\hline 013N003E35B001S & L-1 & 351054116373601 & $01 / 01 / 1955$ & - & - & - & - & 7.6 \\
\hline 013N003E35B001S & - & 351054116373601 & $01 / 07 / 1963$ & - & - & - & - & 9.7 \\
\hline 013N003E35B001S & - & 351054116373601 & $11 / 19 / 1986$ & - & - & - & - & - \\
\hline 013N003E35J001S & LL2-699 & 351019116373501 & $06 / 26 / 2002$ & 40.0 & 142.46 & $<0.2$ & 8.4 & 8.1 \\
\hline 013N003E35J001S & - & 351019116373501 & 05/10/2011 & 22.5 & - & 0.2 & 8.7 & 8.6 \\
\hline 013N003E35J002S & LL2-415 & 351019116373502 & $06 / 25 / 2002$ & 40.0 & 142.86 & 0.8 & 8.6 & 8.2 \\
\hline 013N003E35J002S & - & 351019116373502 & $05 / 10 / 2011$ & 21.0 & - & 1.4 & 8.6 & 8.5 \\
\hline 013N003E35J003S & LL2-190 & 351019116373503 & $06 / 25 / 2002$ & 34.5 & 145.92 & 1.9 & 8.1 & 7.9 \\
\hline
\end{tabular}


Appendix 2. Water-quality data for selected wells and a spring in Langford Basin, Fort Irwin National Training Center, California, 1955-2011.-Continued

[See Well-Numbering System in text. Abbreviations: AL-US, U.S. Environmental Protection Agency (USEPA) action level; CaCO, calcium carbonate; E, estimated; HAL-US, USEPA lifetime health advisory level; $\mathrm{M}$, presence verified but not quantified; MCL-US, USEPA maximum contaminant level; na, not available; NH ${ }_{4}$, ammonium; NL-CA, California Department of Public Health (CDPH) notification level; mg/L, milligrams per liter; pCi/L, picocuries per liter; per mil, parts per million; R, radchem non-detect, below ssLc; $\mathrm{SiO}_{2}$, silicon dioxide; SMCL-CA, CDPH maximum contaminant level;TU, tritium units; $\mu \mathrm{g} / \mathrm{L}$, micrograms per liter; $\mu \mathrm{S} / \mathrm{cm}$, microsiemens per centimeter at 25 degrees Celsius $\left({ }^{\circ} \mathrm{C}\right) ;<$, actual value is less than value shown; - , no data]

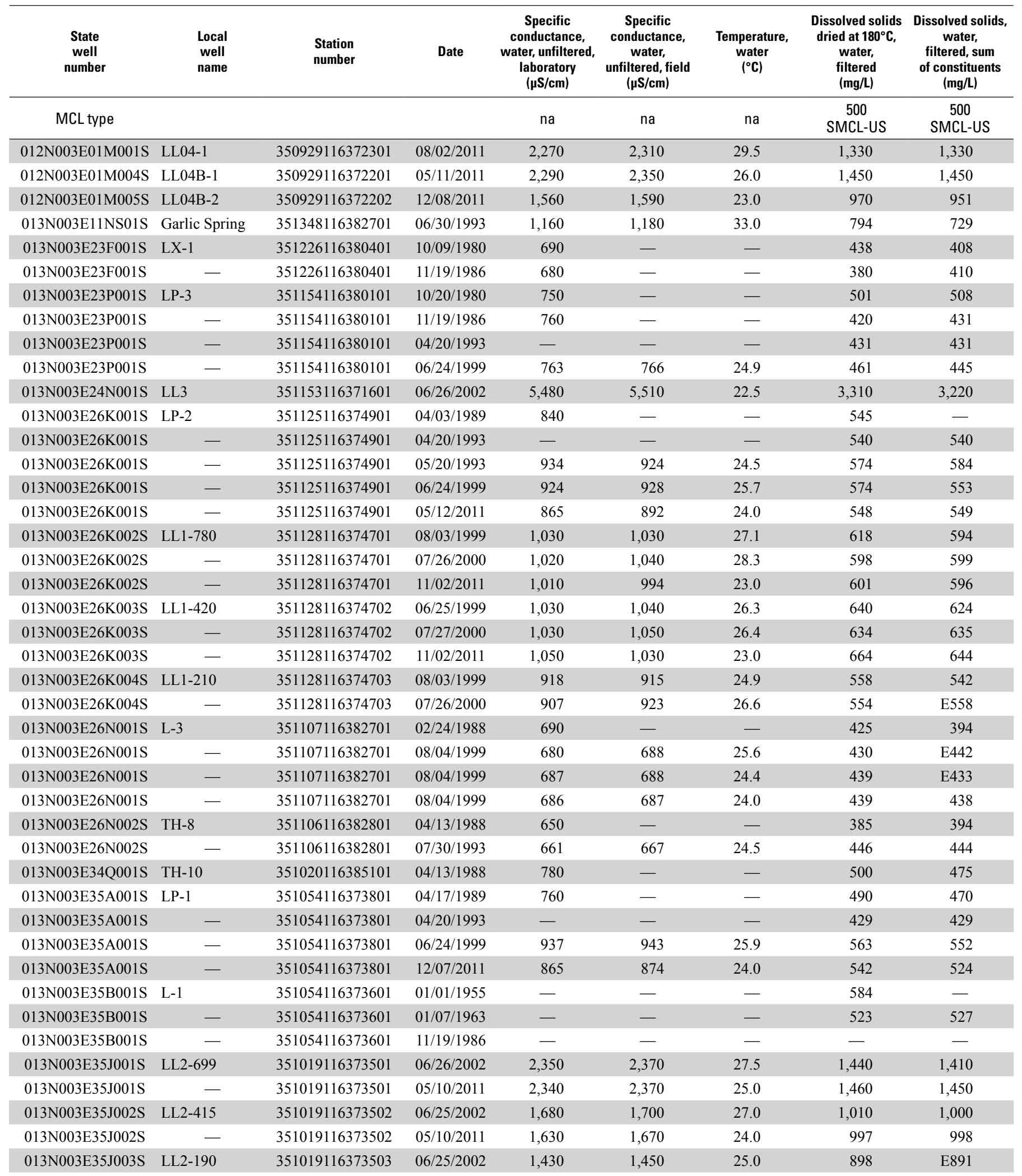


Appendix 2. Water-quality data for selected wells and a spring in Langford Basin, Fort Irwin National Training Center, California, 1955-2011.-Continued

[See Well-Numbering System in text. Abbreviations: AL-US, U.S. Environmental Protection Agency (USEPA) action level; CaCO, calcium carbonate; E, estimated; HAL-US, USEPA lifetime health advisory level; M, presence verified but not quantified; MCL-US, USEPA maximum contaminant level; na, not available; NH${ }_{4}$, ammonium; NL-CA, California Department of Public Health $(\mathrm{CDPH})$ notification level; $\mathrm{mg} / \mathrm{L}$, milligrams per liter; $\mathrm{pCi} / \mathrm{L}$, picocuries per liter; per mil, parts per million; R, radchem non-detect, below ssLc; $\mathrm{SiO}_{2}$, silicon dioxide; SMCL-CA, CDPH maximum contaminant level;TU, tritium units; $\mu \mathrm{g} / \mathrm{L}$, micrograms per liter; $\mu \mathrm{S} / \mathrm{cm}$, microsiemens per centimeter at 25 degrees Celsius $\left({ }^{\circ} \mathrm{C}\right) ;<$, actual value is less than value shown; - , no data]

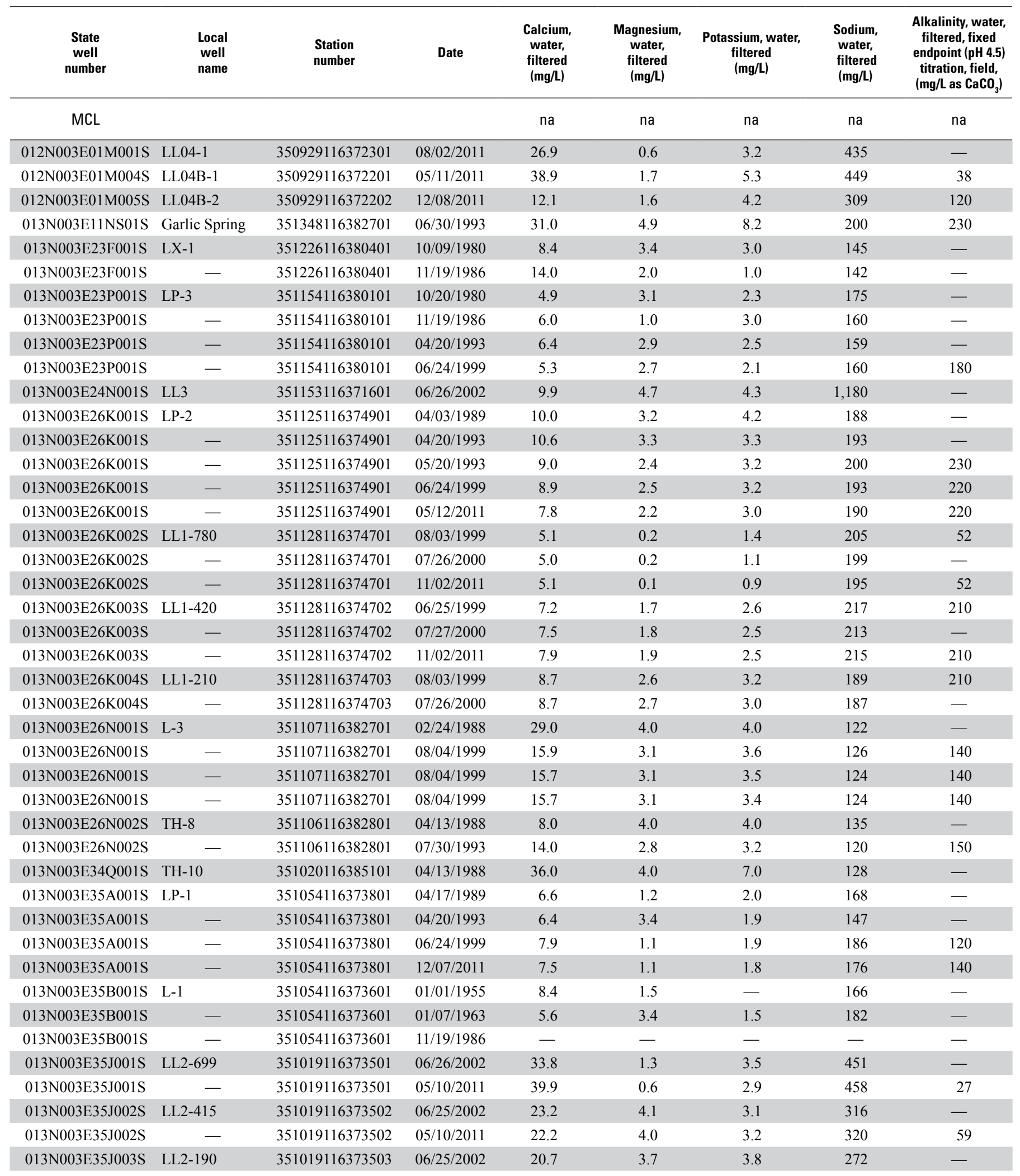


Appendix 2. Water-quality data for selected wells and a spring in Langford Basin, Fort Irwin National Training Center, California, 1955-2011.-Continued

[See Well-Numbering System in text. Abbreviations: AL-US, U.S. Environmental Protection Agency (USEPA) action level; CaCO, calcium carbonate; E, estimated; HAL-US, USEPA lifetime health advisory level; $\mathrm{M}$, presence verified but not quantified; MCL-US, USEPA maximum contaminant level; na, not available; NH, ammonium; NL-CA, California Department of Public Health (CDPH) notification level; mg/L, milligrams per liter; pCi/L, picocuries per liter; per mil, parts per million; $\mathrm{R}$, radchem non-detect, below ssLc; $\mathrm{SiO}{ }_{2}$, silicon dioxide; SMCL-CA, CDPH maximum contaminant level;TU, tritium units; $\mu \mathrm{g} / \mathrm{L}$, micrograms per liter; $\mu \mathrm{S} / \mathrm{cm}$, microsiemens per centimeter at 25 degrees Celsius $\left({ }^{\circ} \mathrm{C}\right) ;<$, actual value is less than value shown; - , no data]

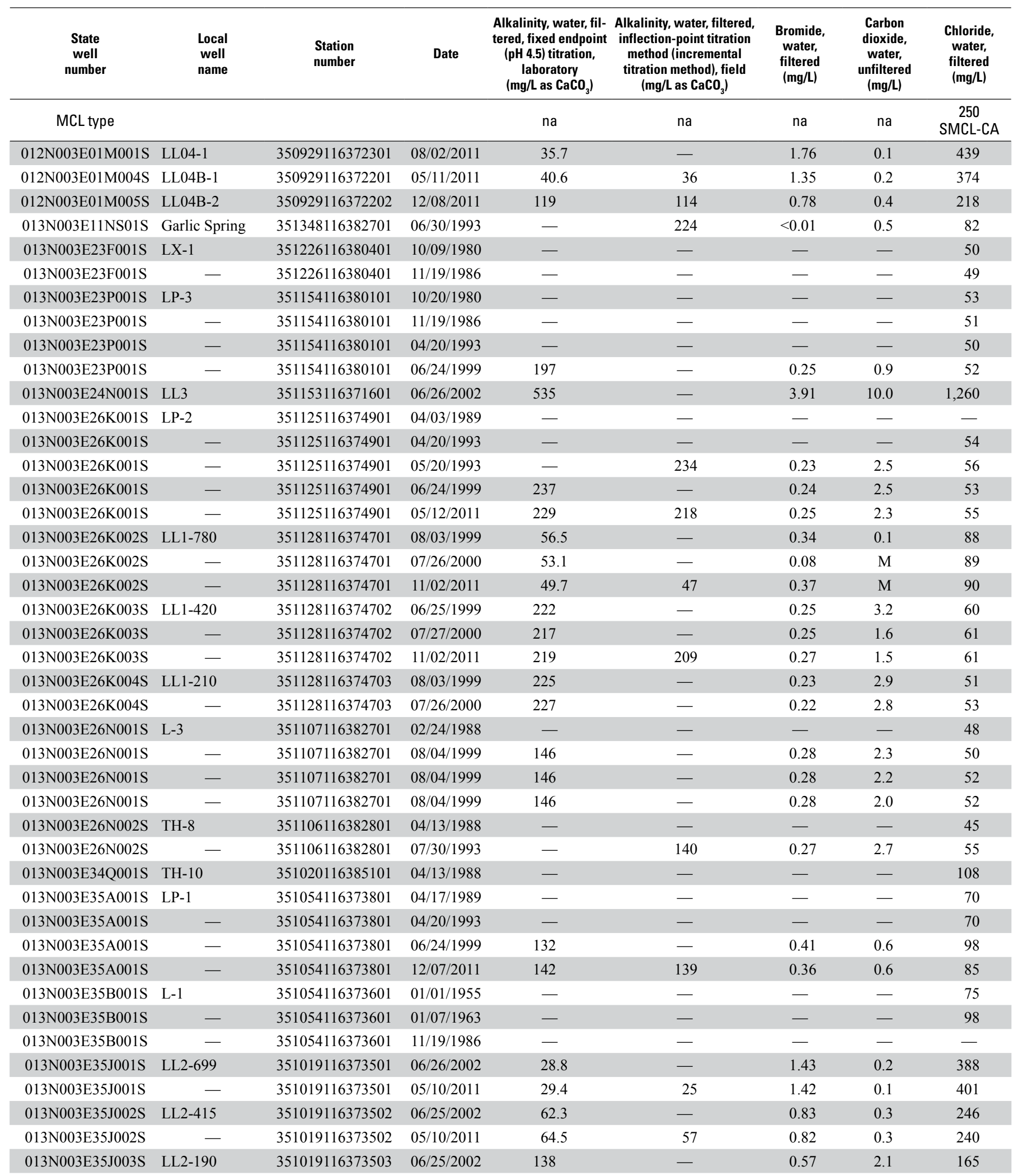


Appendix 2. Water-quality data for selected wells and a spring in Langford Basin, Fort Irwin National Training Center, California, 1955-2011.-Continued

[See Well-Numbering System in text. Abbreviations: AL-US, U.S. Environmental Protection Agency (USEPA) action level; CaCO, calcium carbonate; E, estimated; HAL-US, USEPA lifetime health advisory level; M, presence verified but not quantified; MCL-US, USEPA maximum contaminant level; na, not available; NH${ }_{4}$, ammonium; NL-CA, California Department of Public Health (CDPH) notification level; $\mathrm{mg} / \mathrm{L}$, milligrams per liter; $\mathrm{pCi} / \mathrm{L}$, picocuries per liter; per mil, parts per million; $\mathrm{R}$, radchem non-detect, below ssLc; $\mathrm{SiO}$, silicon dioxide; SMCL-CA, CDPH maximum contaminant level;TU, tritium units; $\mu \mathrm{g} / \mathrm{L}$, micrograms per liter; $\mu \mathrm{S} / \mathrm{cm}$, microsiemens per centimeter at 25 degrees Celsius $\left({ }^{\circ} \mathrm{C}\right) ;<$, actual value is less than value shown; - , no data]

\begin{tabular}{|c|c|c|c|c|c|c|c|c|}
\hline $\begin{array}{c}\text { State } \\
\text { well } \\
\text { number }\end{array}$ & $\begin{array}{l}\text { Local } \\
\text { well } \\
\text { name }\end{array}$ & $\begin{array}{l}\text { Station } \\
\text { number }\end{array}$ & Date & $\begin{array}{c}\text { Fluoride, } \\
\text { water, } \\
\text { filtered } \\
\text { (mg/L) }\end{array}$ & $\begin{array}{c}\text { Silica, } \\
\text { water, } \\
\text { filtered } \\
\left.\text { (mg/Las } \mathrm{SiO}_{2}\right)\end{array}$ & $\begin{array}{c}\text { Sulfate, } \\
\text { water, } \\
\text { filtered } \\
(\mathrm{mg} / \mathrm{L})\end{array}$ & $\begin{array}{c}\text { Ammonia } \\
\text { plus organic } \\
\text { nitrogen, } \\
\text { water, filtered } \\
\text { (mg/L as nitrogen) }\end{array}$ & $\begin{array}{c}\text { Ammonia, } \\
\text { water, } \\
\text { filtered } \\
\text { (mg/L as NH}{ }_{4} \text { ) }\end{array}$ \\
\hline MCL type & & & & $\stackrel{2}{\text { MCL-US }}$ & na & $\begin{array}{c}250 \\
\text { SMCL-CA }\end{array}$ & $\begin{array}{c}24.7 \\
\text { HAL-US } 1\end{array}$ & $\begin{array}{c}24.7 \\
\text { HAL-US }\end{array}$ \\
\hline 012N003E01M001S & LL04-1 & 350929116372301 & $08 / 02 / 2011$ & 3.54 & 16 & 377 & - & - \\
\hline 013N003E11NS01S & Garlic Spring & 351348116382701 & 06/30/1993 & 10.00 & 56 & 200 & 0.60 & 0.039 \\
\hline 013N003E23F001S & LX-1 & 351226116380401 & $10 / 09 / 1980$ & 1.50 & 25 & 69 & - & - \\
\hline 013N003E23F001S & - & 351226116380401 & $11 / 19 / 1986$ & 4.20 & - & 77 & - & - \\
\hline 013N003E23P001S & LP-3 & 351154116380101 & $10 / 20 / 1980$ & 6.50 & 11 & 126 & - & - \\
\hline 013N003E23P001S & - & 351154116380101 & $11 / 19 / 1986$ & 7.20 & - & 82 & - & - \\
\hline 013N003E26K001S & LP-2 & 351125116374901 & 04/03/1989 & 7.40 & - & 98 & - & - \\
\hline 013N003E26K001S & - & 351125116374901 & $04 / 20 / 1993$ & 9.00 & - & 118 & - & - \\
\hline 013N003E26K001S & - & 351125116374901 & 05/20/1993 & 8.20 & 28 & 130 & $<0.20$ & 0.026 \\
\hline 013N003E26K001S & - & 351125116374901 & 06/24/1999 & 7.29 & 27 & 116 & $<0.10$ & $<0.026$ \\
\hline 013N003E26K001S & - & 351125116374901 & $05 / 12 / 2011$ & 8.49 & 27 & 118 & $<0.05$ & $<0.013$ \\
\hline 013N003E26K002S & LL1-780 & 351128116374701 & 08/03/1999 & 11.60 & 17 & 233 & E0.06 & $<0.026$ \\
\hline 013N003E26K002S & - & 351128116374701 & $07 / 26 / 2000$ & 14.70 & 17 & 239 & $<0.10$ & $<0.026$ \\
\hline 013N003E26K002S & - & 351128116374701 & $11 / 02 / 2011$ & 14.00 & 18 & 245 & $<0.07$ & $<0.013$ \\
\hline 013N003E26K003S & LL1-420 & 351128116374702 & 06/25/1999 & 6.73 & 29 & 171 & $<0.10$ & $<0.026$ \\
\hline 013N003E26K003S & - & 351128116374702 & $07 / 27 / 2000$ & 8.69 & 32 & 176 & $<0.10$ & $<0.026$ \\
\hline 013N003E26N002S & TH-8 & 351106116382801 & $04 / 13 / 1988$ & 2.70 & - & 81 & - & - \\
\hline 013N003E26N002S & - & 351106116382801 & 07/30/1993 & 2.90 & 60 & 89 & $<0.20$ & 0.013 \\
\hline 013N003E34Q001S & TH-10 & 351020116385101 & $04 / 13 / 1988$ & 1.50 & - & 174 & - & - \\
\hline 013N003E35A001S & LP-1 & 351054116373801 & 04/17/1989 & 4.70 & - & 115 & - & - \\
\hline 013N003E35A001S & - & 351054116373801 & $04 / 20 / 1993$ & 4.60 & - & 103 & - & - \\
\hline 013N003E35A001S & - & 351054116373801 & 06/24/1999 & 3.96 & 21 & 146 & $<0.10$ & $<0.026$ \\
\hline 013N003E35A001S & - & 351054116373801 & $12 / 07 / 2011$ & 3.98 & 23 & 135 & $<0.07$ & $<0.013$ \\
\hline 013N003E35B001S & $\mathrm{L}-1$ & 351054116373601 & $01 / 01 / 1955$ & 1.80 & 18 & 113 & - & - \\
\hline 013N003E35B001S & - & 351054116373601 & $01 / 07 / 1963$ & 2.00 & - & 139 & - & - \\
\hline 013N003E35B001S & - & 351054116373601 & $11 / 19 / 1986$ & 3.50 & - & - & - & - \\
\hline 013N003E35J001S & LL2-699 & 351019116373501 & $06 / 26 / 2002$ & 0.91 & 16 & 460 & $<0.10$ & $<0.052$ \\
\hline 013N003E35J001S & - & 351019116373501 & 05/10/2011 & 1.06 & 15 & 479 & $<0.05$ & $<0.013$ \\
\hline 013N003E35J002S & LL2-415 & 351019116373502 & $06 / 25 / 2002$ & 1.47 & 15 & 339 & $<0.10$ & $<0.052$ \\
\hline 013N003E35J002S & - & 351019116373502 & 05/10/2011 & 2.26 & 15 & 345 & $<0.05$ & $<0.013$ \\
\hline 013N003E35J003S & LL2-190 & 351019116373503 & $06 / 25 / 2002$ & 1.11 & 40 & 277 & $<0.10$ & $<0.052$ \\
\hline
\end{tabular}


Appendix 2. Water-quality data for selected wells and a spring in Langford Basin, Fort Irwin National Training Center, California, 1955-2011.-Continued

[See Well-Numbering System in text. Abbreviations: AL-US, U.S. Environmental Protection Agency (USEPA) action level; CaCO, calcium carbonate; E, estimated; HAL-US, USEPA lifetime health advisory level; $\mathrm{M}$, presence verified but not quantified; MCL-US, USEPA maximum contaminant level; na, not available; NH, ammonium; NL-CA, California

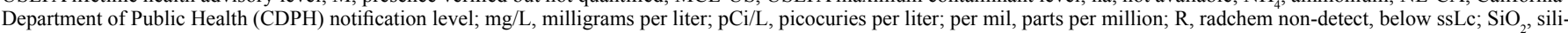
con dioxide; SMCL-CA, CDPH maximum contaminant level;TU, tritium units; $\mu \mathrm{g} / \mathrm{L}$, micrograms per liter; $\mu \mathrm{S} / \mathrm{cm}$, microsiemens per centimeter at 25 degrees Celsius $\left({ }^{\circ} \mathrm{C}\right) ;<$, actual value is less than value shown; - , no data]

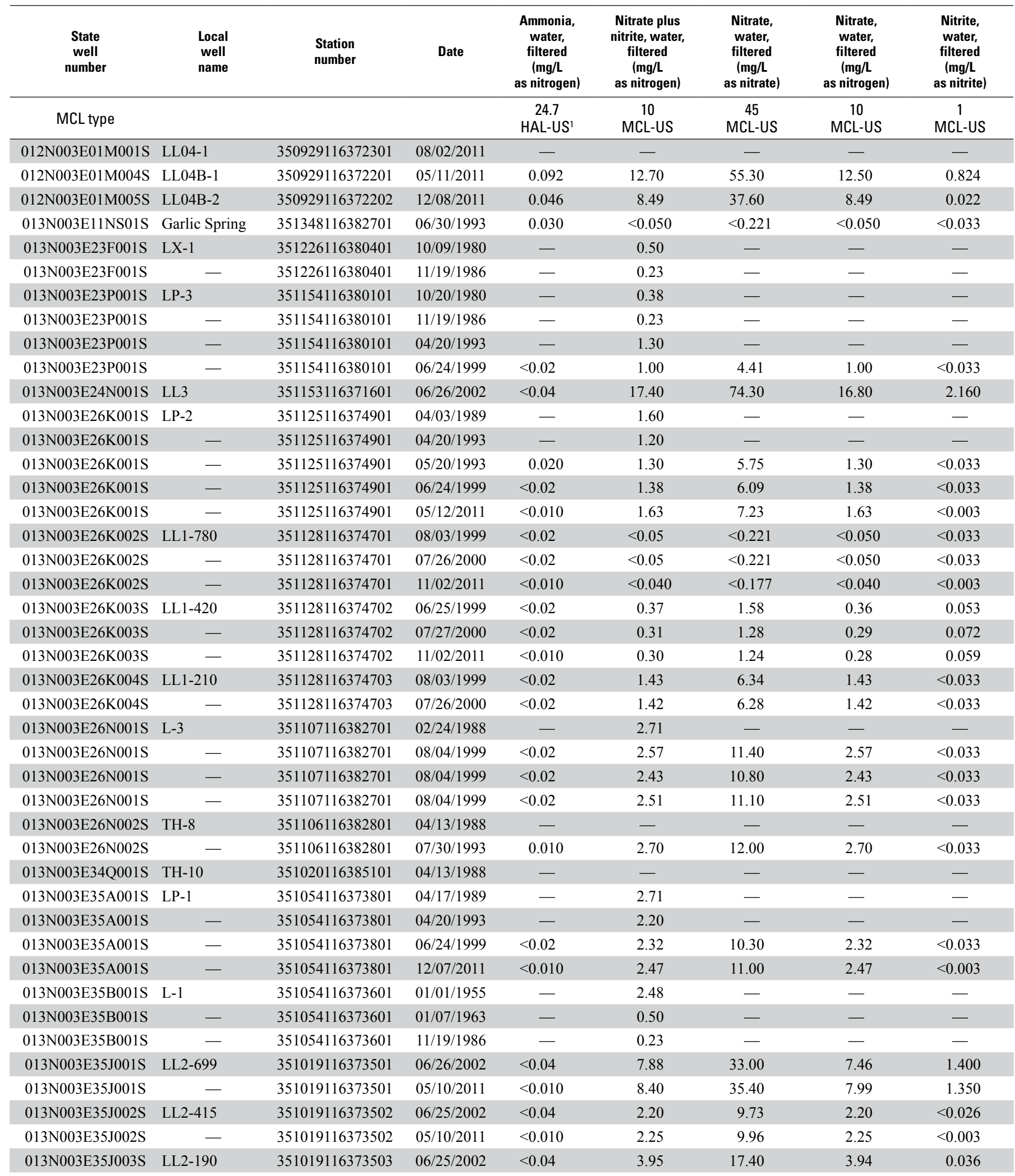


Appendix 2. Water-quality data for selected wells and a spring in Langford Basin, Fort Irwin National Training Center, California, 1955-2011.-Continued

[See Well-Numbering System in text. Abbreviations: AL-US, U.S. Environmental Protection Agency (USEPA) action level; CaCO, calcium carbonate; E, estimated; HAL-US, USEPA lifetime health advisory level; $\mathrm{M}$, presence verified but not quantified; MCL-US, USEPA maximum contaminant level; na, not available; $\mathrm{NH}_{4}$, ammonium; $\mathrm{NL}^{-\mathrm{CA}}$, California Department of Public Health (CDPH) notification level; $\mathrm{mg} / \mathrm{L}$, milligrams per liter; pCi/L, picocuries per liter; per mil, parts per million; R, radchem non-detect, below ssLc; $\mathrm{SiO}{ }_{2}$, silicon dioxide; SMCL-CA, CDPH maximum contaminant level;TU, tritium units; $\mu \mathrm{g} / \mathrm{L}$, micrograms per liter; $\mu \mathrm{S} / \mathrm{cm}$, microsiemens per centimeter at 25 degrees Celsius $\left({ }^{\circ} \mathrm{C}\right) ;<$, actual value is less than value shown; - , no data]

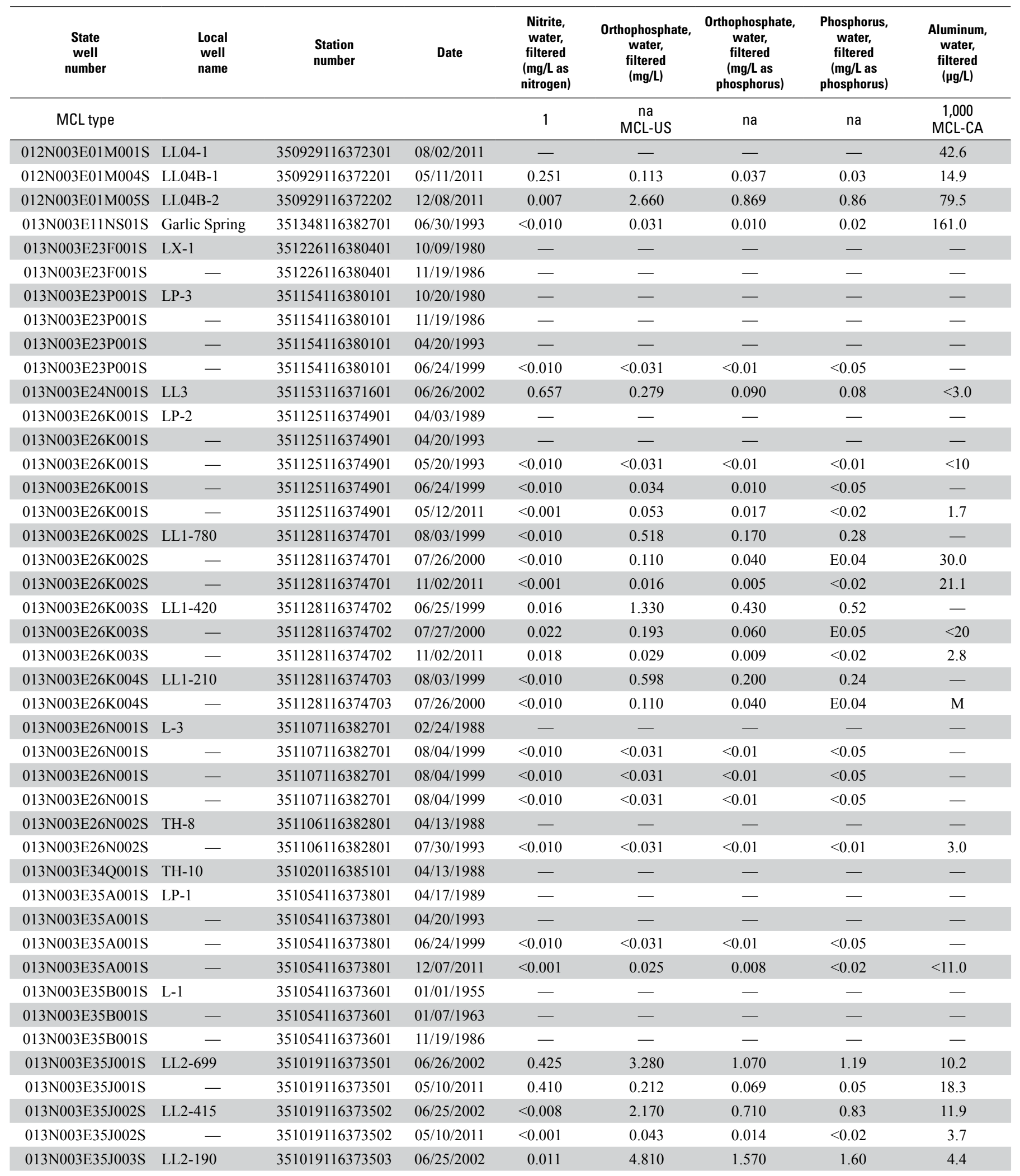


Appendix 2. Water-quality data for selected wells and a spring in Langford Basin, Fort Irwin National Training Center, California, 1955-2011.-Continued

[See Well-Numbering System in text. Abbreviations: AL-US, U.S. Environmental Protection Agency (USEPA) action level; CaCO, calcium carbonate; E, estimated; HAL-US, USEPA lifetime health advisory level; $\mathrm{M}$, presence verified but not quantified; MCL-US, USEPA maximum contaminant level; na, not available; NH, ammonium; NL-CA, California Department of Public Health (CDPH) notification level; mg/L, milligrams per liter; pCi/L, picocuries per liter; per mil, parts per million; $\mathrm{R}$, radchem non-detect, below ssLc; $\mathrm{SiO}{ }_{2}$, silicon dioxide; SMCL-CA, CDPH maximum contaminant level;TU, tritium units; $\mu \mathrm{g} / \mathrm{L}$, micrograms per liter; $\mu \mathrm{S} / \mathrm{cm}$, microsiemens per centimeter at 25 degrees $\mathrm{Celsius}\left({ }^{\circ} \mathrm{C}\right) ;<$, actual value is less than value shown; - , no data]

\begin{tabular}{|c|c|c|c|c|c|c|c|c|}
\hline $\begin{array}{c}\text { State } \\
\text { well } \\
\text { number }\end{array}$ & $\begin{array}{l}\text { Local } \\
\text { well } \\
\text { name }\end{array}$ & $\begin{array}{l}\text { Station } \\
\text { number }\end{array}$ & Date & $\begin{array}{c}\text { Barium, } \\
\text { water, } \\
\text { filtered } \\
(\mu \mathrm{g} / \mathrm{L})\end{array}$ & $\begin{array}{c}\text { Beryllium, } \\
\text { water, } \\
\text { filtered } \\
(\mu \mathrm{g} / \mathrm{L})\end{array}$ & $\begin{array}{l}\text { Cadmium, } \\
\text { water, } \\
\text { filtered } \\
(\mu \mathrm{g} / \mathrm{L})\end{array}$ & $\begin{array}{c}\text { Chromium, } \\
\text { water, } \\
\text { filtered } \\
(\mu \mathrm{g} / \mathrm{L})\end{array}$ & $\begin{array}{c}\text { Cobalt, } \\
\text { water, } \\
\text { filtered } \\
(\mu \mathrm{g} / \mathrm{L})\end{array}$ \\
\hline 012N003E01M001S & LL04-1 & 350929116372301 & $08 / 02 / 2011$ & 16 & - & - & - & - \\
\hline 013N003E11NS01S & Garlic Spring & 351348116382701 & $06 / 30 / 1993$ & 22 & $<1.0$ & $<1.0$ & 2.0 & $<1.0$ \\
\hline 013N003E23F001S & LX-1 & 351226116380401 & $10 / 09 / 1980$ & - & - & - & - & - \\
\hline 013N003E23F001S & - & 351226116380401 & $11 / 19 / 1986$ & - & - & - & - & - \\
\hline 013N003E23P001S & LP-3 & 351154116380101 & $10 / 20 / 1980$ & - & - & - & - & - \\
\hline 013N003E23P001S & - & 351154116380101 & $11 / 19 / 1986$ & - & - & - & - & - \\
\hline 013N003E26K001S & LP-2 & 351125116374901 & 04/03/1989 & - & - & - & - & - \\
\hline 013N003E26K001S & - & 351125116374901 & $04 / 20 / 1993$ & - & - & - & - & - \\
\hline 013N003E26K001S & - & 351125116374901 & 05/20/1993 & 14 & $<0.5$ & $<1.0$ & - & $<1.0$ \\
\hline 013N003E26K001S & - & 351125116374901 & $06 / 24 / 1999$ & 15 & - & - & - & - \\
\hline 013N003E26K001S & - & 351125116374901 & $05 / 12 / 2011$ & 12 & - & - & - & - \\
\hline 013N003E26K002S & LL1-780 & 351128116374701 & 08/03/1999 & 7 & - & - & - & - \\
\hline 013N003E26K002S & - & 351128116374701 & $07 / 26 / 2000$ & 4 & - & - & - & - \\
\hline 013N003E26K002S & - & 351128116374701 & $11 / 02 / 2011$ & 3 & - & - & - & - \\
\hline 013N003E26K003S & LL1-420 & 351128116374702 & $06 / 25 / 1999$ & 11 & - & - & - & - \\
\hline 013N003E26K003S & - & 351128116374702 & $07 / 27 / 2000$ & 11 & - & - & - & - \\
\hline 013N003E26K003S & - & 351128116374702 & $11 / 02 / 2011$ & 9 & - & - & - & - \\
\hline 013N003E26N002S & TH-8 & 351106116382801 & 04/13/1988 & - & - & - & - & - \\
\hline 013N003E26N002S & - & 351106116382801 & 07/30/1993 & 31 & $<1.0$ & $<1.0$ & 4.0 & $<1.0$ \\
\hline 013N003E34Q001S & TH-10 & 351020116385101 & $04 / 13 / 1988$ & - & - & - & - & - \\
\hline 013N003E35A001S & LP-1 & 351054116373801 & 04/17/1989 & - & - & - & - & - \\
\hline 013N003E35A001S & - & 351054116373801 & $04 / 20 / 1993$ & - & - & - & - & - \\
\hline 013N003E35A001S & - & 351054116373801 & $06 / 24 / 1999$ & 13 & - & - & - & - \\
\hline 013N003E35A001S & - & 351054116373801 & $12 / 07 / 2011$ & 11 & - & - & - & - \\
\hline 013N003E35B001S & L-1 & 351054116373601 & 01/01/1955 & - & - & - & - & - \\
\hline 013N003E35B001S & - & 351054116373601 & $01 / 07 / 1963$ & - & - & - & - & - \\
\hline 013N003E35B001S & - & 351054116373601 & $11 / 19 / 1986$ & - & - & - & - & - \\
\hline 013N003E35J001S & LL2-699 & 351019116373501 & $06 / 26 / 2002$ & 16 & - & - & $<0.8$ & - \\
\hline 013N003E35J001S & - & 351019116373501 & $05 / 10 / 2011$ & 14 & - & - & - & - \\
\hline 013N003E35J002S & LL2-415 & 351019116373502 & $06 / 25 / 2002$ & 14 & - & - & $<0.8$ & - \\
\hline 013N003E35J002S & - & 351019116373502 & $05 / 10 / 2011$ & 14 & - & - & - & - \\
\hline 013N003E35J003S & LL2-190 & 351019116373503 & $06 / 25 / 2002$ & 8 & - & - & E0.6 & - \\
\hline
\end{tabular}


Appendix 2. Water-quality data for selected wells and a spring in Langford Basin, Fort Irwin National Training Center, California, 1955-2011.-Continued

[See Well-Numbering System in text. Abbreviations: AL-US, U.S. Environmental Protection Agency (USEPA) action level; CaCO, calcium carbonate; E, estimated; HAL-US, USEPA lifetime health advisory level; M, presence verified but not quantified; MCL-US, USEPA maximum contaminant level; na, not available; $\mathrm{NH}_{4}$, ammonium; NL-CA, California Department of Public Health (CDPH) notification level; $\mathrm{mg} / \mathrm{L}$, milligrams per liter; pCi/L, picocuries per liter; per mil, parts per million; $\mathrm{R}$, radchem non-detect, below ssLc; $\mathrm{SiO}{ }_{2}$, silicon dioxide; SMCL-CA, CDPH maximum contaminant level;TU, tritium units; $\mu \mathrm{g} / \mathrm{L}$, micrograms per liter; $\mu \mathrm{S} / \mathrm{cm}$, microsiemens per centimeter at 25 degrees $\mathrm{Celsius}\left({ }^{\circ} \mathrm{C}\right) ;<$, actual value is less than value shown; - , no data]

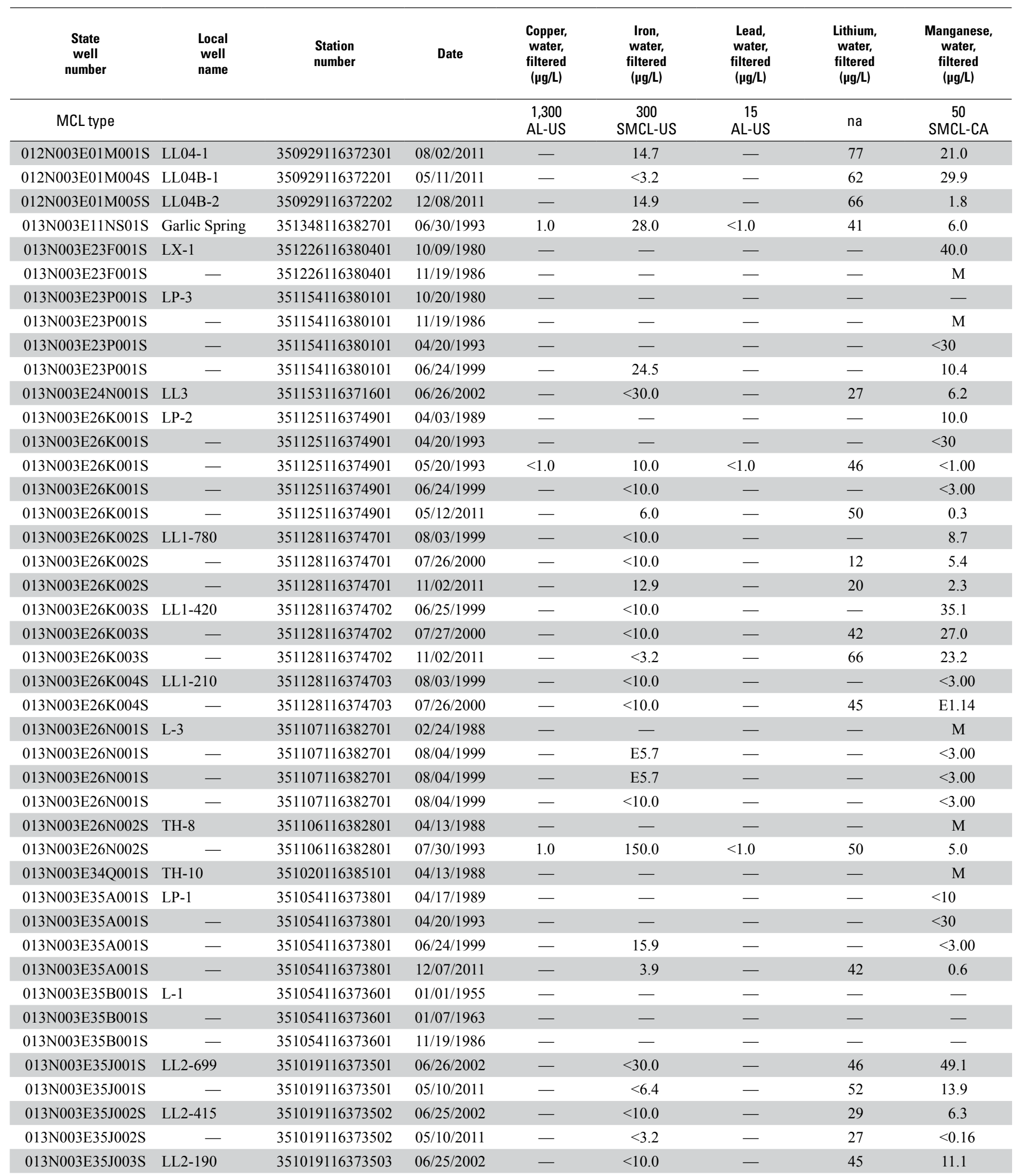


Appendix 2. Water-quality data for selected wells and a spring in Langford Basin, Fort Irwin National Training Center, California, 1955-2011.-Continued

[See Well-Numbering System in text. Abbreviations: AL-US, U.S. Environmental Protection Agency (USEPA) action level; CaCO, calcium carbonate; E, estimated; HAL-US, USEPA lifetime health advisory level; $\mathrm{M}$, presence verified but not quantified; MCL-US, USEPA maximum contaminant level; na, not available; NH, ammonium; NL-CA, California Department of Public Health (CDPH) notification level; mg/L, milligrams per liter; pCi/L, picocuries per liter; per mil, parts per million; $\mathrm{R}$, radchem non-detect, below ssLc; $\mathrm{SiO}{ }_{2}$, silicon dioxide; SMCL-CA, CDPH maximum contaminant level;TU, tritium units; $\mu \mathrm{g} / \mathrm{L}$, micrograms per liter; $\mu \mathrm{S} / \mathrm{cm}$, microsiemens per centimeter at 25 degrees $\mathrm{Celsius}\left({ }^{\circ} \mathrm{C}\right) ;<$, actual value is less than value shown; - , no data]

\begin{tabular}{|c|c|c|c|c|c|c|c|c|}
\hline MCL type & & & & $\begin{array}{c}40 \\
\text { HAL-US }\end{array}$ & $\begin{array}{c}100 \\
\text { MCL-US }\end{array}$ & $\begin{array}{c}100 \\
\text { SMCL-CA }\end{array}$ & $\begin{array}{c}4,000 \\
\text { HAL-US }\end{array}$ & ${ }^{2}$ \\
\hline 012N003E01M001S & LL04-1 & 350929116372301 & $08 / 02 / 2011$ & - & - & - & 772 & - \\
\hline 013N003E11NS01S & Garlic Spring & 351348116382701 & $06 / 30 / 1993$ & 90 & $<1.0$ & $<1.0$ & 470 & - \\
\hline 013N003E23F001S & LX-1 & 351226116380401 & $10 / 09 / 1980$ & - & - & - & - & - \\
\hline 013N003E23F001S & - & 351226116380401 & $11 / 19 / 1986$ & - & - & - & - & - \\
\hline 013N003E23P001S & LP-3 & 351154116380101 & $10 / 20 / 1980$ & - & - & - & - & - \\
\hline 013N003E23P001S & - & 351154116380101 & $11 / 19 / 1986$ & - & - & - & - & - \\
\hline 013N003E26K001S & LP-2 & 351125116374901 & $04 / 03 / 1989$ & - & - & - & - & - \\
\hline 013N003E26K001S & - & 351125116374901 & $04 / 20 / 1993$ & - & - & - & - & - \\
\hline 013N003E26K001S & - & 351125116374901 & $05 / 20 / 1993$ & 41 & $<1.0$ & $<1.0$ & 260 & - \\
\hline 013N003E26K001S & - & 351125116374901 & $06 / 24 / 1999$ & - & - & - & 251 & - \\
\hline 013N003E26K001S & - & 351125116374901 & $05 / 12 / 2011$ & - & - & - & 231 & - \\
\hline 013N003E26K002S & LL1-780 & 351128116374701 & 08/03/1999 & - & - & - & 135 & - \\
\hline 013N003E26K002S & - & 351128116374701 & $07 / 26 / 2000$ & - & - & - & 125 & - \\
\hline 013N003E26K002S & - & 351128116374701 & $11 / 02 / 2011$ & - & - & - & 128 & - \\
\hline 013N003E26K003S & LL1-420 & 351128116374702 & $06 / 25 / 1999$ & - & - & - & 214 & - \\
\hline 013N003E26K003S & - & 351128116374702 & $07 / 27 / 2000$ & - & - & - & 216 & - \\
\hline 013N003E26N002S & TH-8 & 351106116382801 & $04 / 13 / 1988$ & - & - & - & - & - \\
\hline 013N003E26N002S & - & 351106116382801 & $07 / 30 / 1993$ & 22 & $<1.0$ & $<1.0$ & 420 & $<0.5$ \\
\hline 013N003E34Q001S & TH-10 & 351020116385101 & $04 / 13 / 1988$ & - & - & - & - & - \\
\hline 013N003E35A001S & LP-1 & 351054116373801 & $04 / 17 / 1989$ & - & - & - & - & - \\
\hline 013N003E35A001S & - & 351054116373801 & $04 / 20 / 1993$ & - & - & - & - & - \\
\hline 013N003E35A001S & - & 351054116373801 & $06 / 24 / 1999$ & - & - & - & 303 & - \\
\hline 013N003E35A001S & - & 351054116373801 & $12 / 07 / 2011$ & - & - & - & 313 & - \\
\hline 013N003E35B001S & L-1 & 351054116373601 & $01 / 01 / 1955$ & - & - & - & - & - \\
\hline 013N003E35B001S & - & 351054116373601 & $01 / 07 / 1963$ & - & - & - & - & - \\
\hline 013N003E35B001S & - & 351054116373601 & $11 / 19 / 1986$ & - & - & - & - & - \\
\hline 013N003E35J001S & LL2-699 & 351019116373501 & $06 / 26 / 2002$ & - & - & - & 1,230 & - \\
\hline 013N003E35J001S & - & 351019116373501 & 05/10/2011 & - & - & - & 1,410 & - \\
\hline 013N003E35J002S & LL2-415 & 351019116373502 & $06 / 25 / 2002$ & - & - & - & 967 & - \\
\hline 013N003E35J002S & - & 351019116373502 & $05 / 10 / 2011$ & - & - & - & 929 & - \\
\hline 013N003E35J003S & LL2-190 & 351019116373503 & $06 / 25 / 2002$ & - & - & - & 544 & - \\
\hline
\end{tabular}


Appendix 2. Water-quality data for selected wells and a spring in Langford Basin, Fort Irwin National Training Center, California, 1955-2011.-Continued

[See Well-Numbering System in text. Abbreviations: AL-US, U.S. Environmental Protection Agency (USEPA) action level; CaCO, calcium carbonate; E, estimated; HAL-US, USEPA lifetime health advisory level; $\mathrm{M}$, presence verified but not quantified; MCL-US, USEPA maximum contaminant level; na, not available; $\mathrm{NH}_{4}$, ammonium; $\mathrm{NL}^{-\mathrm{CA}}$, California Department of Public Health (CDPH) notification level; $\mathrm{mg} / \mathrm{L}$, milligrams per liter; pCi/L, picocuries per liter; per mil, parts per million; $\mathrm{R}$, radchem non-detect, below ssLc; $\mathrm{SiO}{ }_{2}$, silicon dioxide; SMCL-CA, CDPH maximum contaminant level;TU, tritium units; $\mu \mathrm{g} / \mathrm{L}$, micrograms per liter; $\mu \mathrm{S} / \mathrm{cm}$, microsiemens per centimeter at 25 degrees $\mathrm{Celsius}\left({ }^{\circ} \mathrm{C}\right) ;<$, actual value is less than value shown; - , no data]

\begin{tabular}{|c|c|c|c|c|c|c|c|c|}
\hline MCL type & & & & $\begin{array}{c}50 \\
\text { NL-CA }\end{array}$ & $\begin{array}{c}5,000 \\
\text { SMCL-CA }\end{array}$ & $\begin{array}{c}6 \\
\text { MCL-US }\end{array}$ & $\begin{array}{c}10 \\
\text { MCL-US }\end{array}$ & $\begin{array}{r}1,000 \\
\text { NL-CA }\end{array}$ \\
\hline 012N003E01M001S & LL04-1 & 350929116372301 & $08 / 02 / 2011$ & - & - & - & 2.4 & 205 \\
\hline 013N003E11NS01S & Garlic Spring & 351348116382701 & $06 / 30 / 1993$ & - & 2 & $<1.0$ & 21.0 & 1,800 \\
\hline 013N003E23F001S & LX-1 & 351226116380401 & $10 / 09 / 1980$ & - & - & - & - & - \\
\hline 013N003E23F001S & - & 351226116380401 & $11 / 19 / 1986$ & - & - & - & - & - \\
\hline 013N003E23P001S & LP-3 & 351154116380101 & $10 / 20 / 1980$ & - & - & - & - & - \\
\hline 013N003E23P001S & - & 351154116380101 & $11 / 19 / 1986$ & - & - & - & - & - \\
\hline 013N003E26K001S & LP-2 & 351125116374901 & 04/03/1989 & - & - & - & - & - \\
\hline 013N003E26K001S & - & 351125116374901 & $04 / 20 / 1993$ & - & - & - & - & - \\
\hline 013N003E26K001S & - & 351125116374901 & $05 / 20 / 1993$ & 33 & 10 & 2 & 6.0 & 790 \\
\hline 013N003E26K001S & - & 351125116374901 & $06 / 24 / 1999$ & - & - & - & 5.0 & 803 \\
\hline 013N003E26K001S & - & 351125116374901 & $05 / 12 / 2011$ & - & - & - & 7.5 & 753 \\
\hline 013N003E26K002S & LL1-780 & 351128116374701 & 08/03/1999 & - & - & - & 16.0 & 755 \\
\hline 013N003E26K002S & - & 351128116374701 & $07 / 26 / 2000$ & - & - & - & 17.0 & 723 \\
\hline 013N003E26K002S & - & 351128116374701 & $11 / 02 / 2011$ & - & - & - & 6.8 & 715 \\
\hline 013N003E26K003S & LL1-420 & 351128116374702 & 06/25/1999 & - & - & - & 6.0 & 802 \\
\hline 013N003E26K003S & - & 351128116374702 & $07 / 27 / 2000$ & - & - & - & 6.0 & 777 \\
\hline 013N003E26N002S & TH-8 & 351106116382801 & $04 / 13 / 1988$ & - & - & - & - & - \\
\hline 013N003E26N002S & - & 351106116382801 & 07/30/1993 & - & 5 & $<1.0$ & 8.0 & 670 \\
\hline 013N003E34Q001S & TH-10 & 351020116385101 & $04 / 13 / 1988$ & - & - & - & - & - \\
\hline 013N003E35A001S & LP-1 & 351054116373801 & $04 / 17 / 1989$ & - & - & - & - & - \\
\hline 013N003E35A001S & - & 351054116373801 & $04 / 20 / 1993$ & - & - & - & - & - \\
\hline 013N003E35A001S & - & 351054116373801 & 06/24/1999 & - & - & - & 11.0 & 771 \\
\hline 013N003E35A001S & - & 351054116373801 & $12 / 07 / 2011$ & - & - & - & 10.8 & 769 \\
\hline 013N003E35B001S & $\mathrm{L}-1$ & 351054116373601 & $01 / 01 / 1955$ & - & - & - & - & - \\
\hline 013N003E35B001S & - & 351054116373601 & $01 / 07 / 1963$ & - & - & - & - & - \\
\hline 013N003E35B001S & - & 351054116373601 & $11 / 19 / 1986$ & - & - & - & - & - \\
\hline 013N003E35J001S & LL2-699 & 351019116373501 & $06 / 26 / 2002$ & - & - & - & 5.7 & 812 \\
\hline 013N003E35J001S & - & 351019116373501 & $05 / 10 / 2011$ & - & - & - & 4.2 & 731 \\
\hline 013N003E35J002S & LL2-415 & 351019116373502 & $06 / 25 / 2002$ & - & - & - & 9.2 & 1,620 \\
\hline 013N003E35J002S & - & 351019116373502 & $05 / 10 / 2011$ & - & - & - & 9.1 & 1,540 \\
\hline 013N003E35J003S & LL2-190 & 351019116373503 & $06 / 25 / 2002$ & - & - & - & 25.4 & 1,910 \\
\hline
\end{tabular}


Appendix 2. Water-quality data for selected wells and a spring in Langford Basin, Fort Irwin National Training Center, California, 1955-2011.-Continued

[See Well-Numbering System in text. Abbreviations: AL-US, U.S. Environmental Protection Agency (USEPA) action level; CaCO, calcium carbonate; E, estimated; HAL-US, USEPA lifetime health advisory level; $\mathrm{M}$, presence verified but not quantified; MCL-US, USEPA maximum contaminant level; na, not available; NH, ammonium; NL-CA, California Department of Public Health (CDPH) notification level; mg/L, milligrams per liter; pCi/L, picocuries per liter; per mil, parts per million; $\mathrm{R}$, radchem non-detect, below ssLc; $\mathrm{SiO}{ }_{2}$, silicon dioxide; SMCL-CA, CDPH maximum contaminant level;TU, tritium units; $\mu \mathrm{g} / \mathrm{L}$, micrograms per liter; $\mu \mathrm{S} / \mathrm{cm}$, microsiemens per centimeter at 25 degrees Celsius $\left({ }^{\circ} \mathrm{C}\right) ;<$, actual value is less than value shown; - , no data]

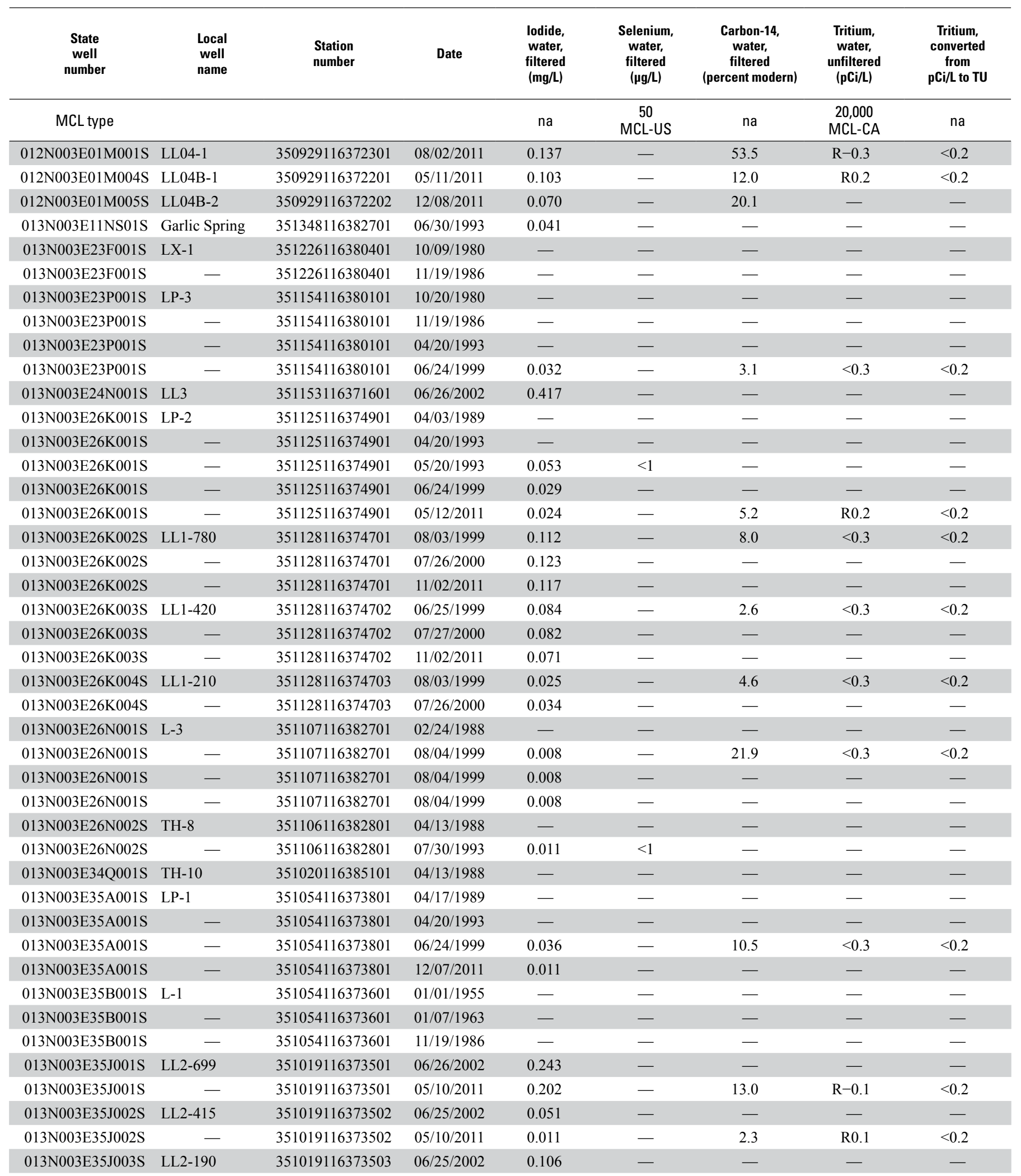


Appendix 2. Water-quality data for selected wells and a spring in Langford Basin, Fort Irwin National Training Center, California, 1955-2011.-Continued

[See Well-Numbering System in text. Abbreviations: AL-US, U.S. Environmental Protection Agency (USEPA) action level; CaCO, calcium carbonate; E, estimated; HAL-US, USEPA lifetime health advisory level; M, presence verified but not quantified; MCL-US, USEPA maximum contaminant level; na, not available; $\mathrm{NH}_{4}$, ammonium; NL-CA, California Department of Public Health (CDPH) notification level; $\mathrm{mg} / \mathrm{L}$, milligrams per liter; pCi/L, picocuries per liter; per mil, parts per million; $\mathrm{R}$, radchem non-detect, below ssLc; $\mathrm{SiO}{ }_{2}$, silicon dioxide; SMCL-CA, CDPH maximum contaminant level;TU, tritium units; $\mu \mathrm{g} / \mathrm{L}$, micrograms per liter; $\mu \mathrm{S} / \mathrm{cm}$, microsiemens per centimeter at 25 degrees Celsius $\left({ }^{\circ} \mathrm{C}\right) ;<$, actual value is less than value shown; - , no data]

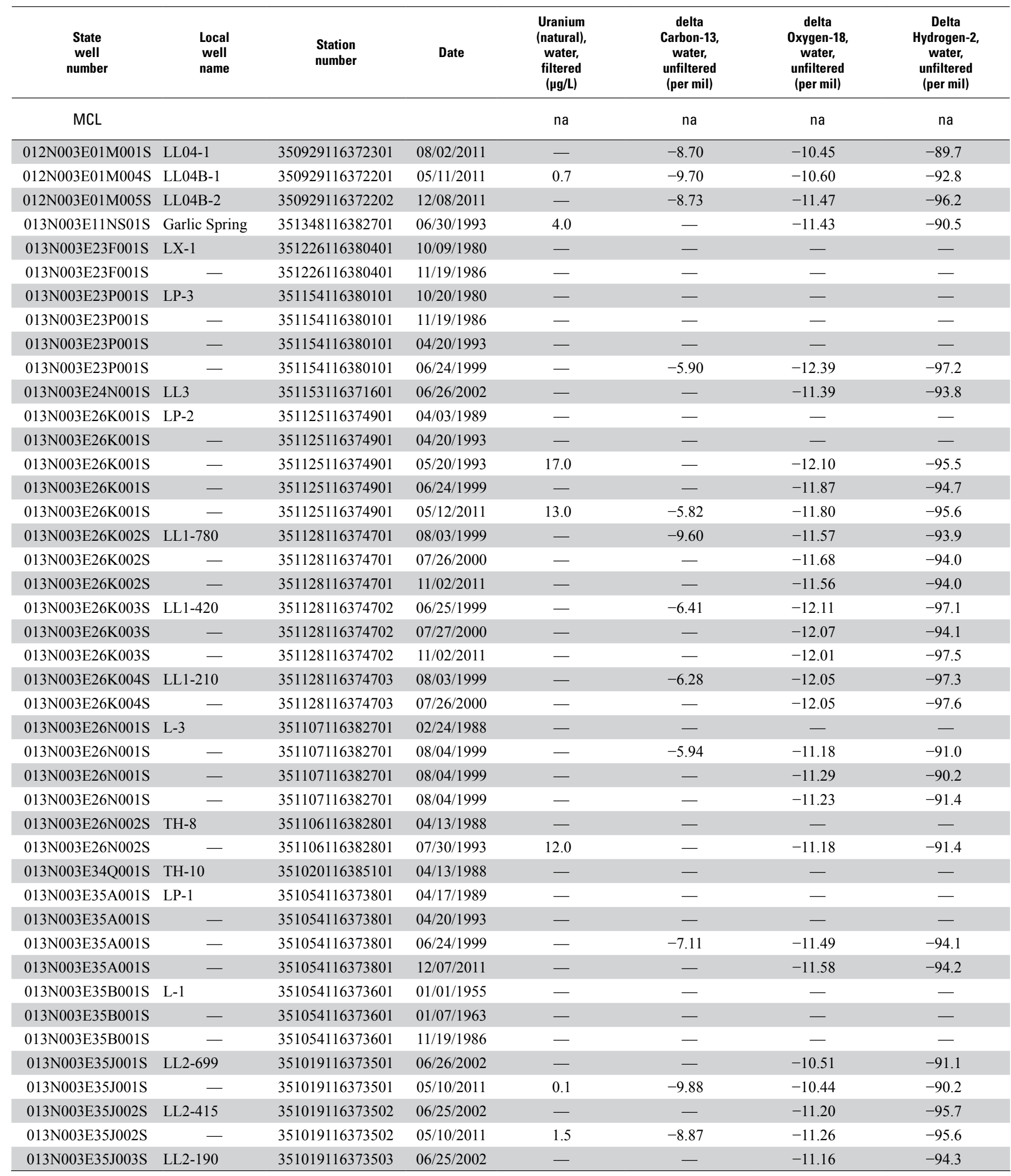

${ }^{1}$ The Hal-US is $30 \mathrm{mg} / \mathrm{L}$ "as ammonia." For comparison to the analytical results, this HAL-US has been converted and reported as $24.7 \mathrm{mg} / \mathrm{L}$ "as nitrogen." 

율 훙.

䓂

잉웅

우

言

!

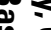

些

오옴

올 을.

एँ

J

동ㄱㅇ

ज

응

is

홍.

哀

옼

를

童

뭉

올

흘

沗

흠

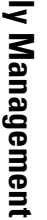

